\title{
(1) pinmhalina
}

Platão

Autor(es): $\quad$ Trabattoni, Franco

Publicado por: Imprensa da Universidade de Coimbra

URL

persistente: URI:http://hdl.handle.net/10316.2/34790

DOI: $\quad$ DOI:http://dx.doi.org/10.14195/978-989-26-0947-8

Accessed : $\quad$ 26-Apr-2023 10:21:00

A navegação consulta e descarregamento dos títulos inseridos nas Bibliotecas Digitais UC Digitalis, UC Pombalina e UC Impactum, pressupõem a aceitação plena e sem reservas dos Termos e Condições de Uso destas Bibliotecas Digitais, disponíveis em https://digitalis.uc.pt/pt-pt/termos.

Conforme exposto nos referidos Termos e Condições de Uso, o descarregamento de títulos de acesso restrito requer uma licença válida de autorização devendo o utilizador aceder ao(s) documento(s) a partir de um endereço de IP da instituição detentora da supramencionada licença.

Ao utilizador é apenas permitido o descarregamento para uso pessoal, pelo que o emprego do(s) título(s) descarregado(s) para outro fim, designadamente comercial, carece de autorização do respetivo autor ou editor da obra.

Na medida em que todas as obras da UC Digitalis se encontram protegidas pelo Código do Direito de Autor e Direitos Conexos e demais legislação aplicável, toda a cópia, parcial ou total, deste documento, nos casos em que é legalmente admitida, deverá conter ou fazer-se acompanhar por este aviso.

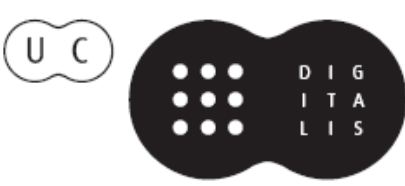




\section{Platão}

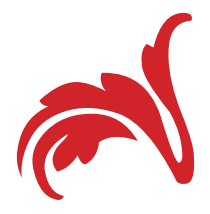

\section{FrANCO TRABATTONI}
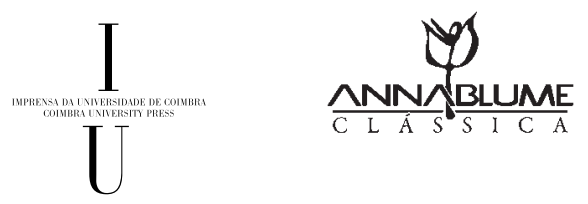
(Página deixada propositadamente em branco) 
Platão 
(Página deixada propositadamente em branco) 


\section{Platão}

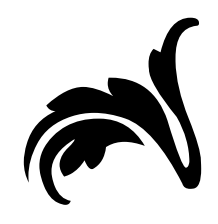

Franco Trabattoni

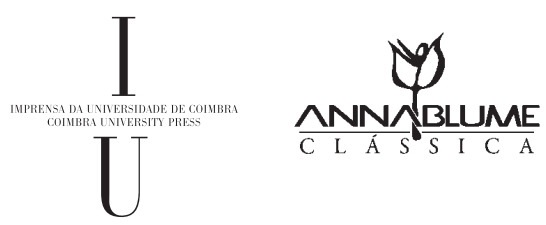




\section{COEDIÇÃO}

Imprensa da Universidade de Coimbra URL: http://www.uc.pt/imprensa_uc

ANNABLUME editora . comunicação www.annablume.com.br

PROJETO E PRODUÇÃO

Coletivo Gráfico Annablume

\section{IMPRESSÃO E ACABAMENTO}

LinkPrint

ISBN

978-989-26-0259-2 (IUC)

978-85-391-0086-6 (Annablume)

ISBN Digital

978-989-26-0947-8

DOI

http://dx.doi.org/10.14195/978-989-26-0947-8

DEPÓSITO LEGAL

$350535 / 12$

(C) JUNHO 2012

ANNABLUME

IMPRENSA DA UNIVERSIDADE DE COIMBRA 


\section{SUMÁRIO}

APRESENTAÇÃO

CAPÍTULO I. VIDA E OBRA 11

CAPÍTULO II. SÓCRATES E PLATÃO:

A ORIENTAÇÃO ÉTICA E POLÍTICA 27

CAPÍTULO III. A CRÍTICA À CULTURA TRADICIONAL 35

CAPÍTULO IV. PLATÃO E A SOFÍSTICA 49

CAPÍTULO V. A CONCEPÇÃO PLATÔNICA DA REALIDADE

$\begin{array}{ll}\text { E DO CONHECIMENTO } & 71\end{array}$

CAPÍTULO VI. A DESCOBERTA DA DIMENSÃO IDEAL

E AS CARACTERÍSTICAS DA METAFÍSICA PLATÔNICA 85

CAPÍTULO VII. METAFÍSICA E EPISTEMOLOGIA

N'A REPÚBLICA 111 
CAPÍTULO IX. O AMOR PLATÔNICO E A EDUCAÇÃO DA ALMA

CAPÍTULO X. A ÉTICA E A POLÍTICA N’A REPÚBLICA 165

CAPÍTULO XI. AS IDEIAS, O CONHECIMENTO, A DIALÉTICA

CAPÍTULO XII. O BEM NO HOMEM E NO COSMOS: o FILEBO E o TIMEU

CAPÍTULO XIII. O ÚLTIMO PENSAMENTO POLÍTICO DE PLATÃO: O POLÍTICO E AS LEIS 


\title{
APRESENTAÇÃO
}

\author{
GABRIELE CORNELLI ${ }^{1}$
}

Tá autores imprescindíveis. Platão, um 1 dos principais protagonistas da história do pensamento filosófico ocidental, é certamente um deles. Ainda ecoa, em sua polêmica ousadia, a célebre expressão de Whitehead, pela qual "a maneira mais segura de definir a tradição filosófica europeia é afirmar que ela consiste numa série de notas-de-rodapé a Platão". ${ }^{2}$ Verdadeiro Proteu da história do pensamento, dificilmente apanhável em sua complexidade, Platão e sua filosofia foram obviamente objeto de diversas tentativas de apresentação e propedêutica à leitura. Entre elas, a mais recente, é este Platão de Trabattoni, que possui algumas vantagens invejáveis quando compa-

1. Presidente da Sociedade Brasileira de Platonistas. Coordenador do Grupo Archai: as origens do pensamento ocidental

2. Cf. Whitehead, A. N. Process and reality. Nova Ioque: Free Press, 1978. 
rado a outras obras de introdução a Platão disponíveis no mercado editorial.

Franco Trabattoni, Professor Titular do Departamento de Filosofia da Università degli Studi di Milano, é indiscutivelmente um dos mais importantes intérpretes de Platão de nossos dias. Suas pesquisas e incursôes nas temáticas da escrita e da oralidade na obra platônica são bem conhecidas do público brasileiro. ${ }^{3}$ Assim como sua figura alegre e descontraída, que há algum tempo frequenta os seminários e os colóquios de filosofia antiga, brasileiros ou não.

Estudioso atento e reconhecido, tanto das fontes do platonismo como da história de sua interpretação, Trabattoni revela nesta obra a rara conjugação da "ponta" da pesquisa com uma grande capacidade de síntese e exposição do pensamento de Platão, desenvolvida certamente graças a uma longa experiência de ensino de filosofia antiga em nível médio e superior.

A presente obra, que Trabattoni jocosamente gosta de chamar de seu Plato minor, a sublinhar exatamente a proposta de ser um manual sintético do pensamento platônico, é pela verdade uma publicação de amplo fôlego e ambição. Uma publicação cujo projeto requer certa coragem e não pouca autoridade, por se propor a percorrer, em poucas páginas, um âmbito de pesquisa

3. Cf. Trabattoni, F. Oralidade e escrita em Platão. Trad. Fernando Rey Puente e Roberto B. Filho. São Paulo; Ilhéus: Discurso Editorial,2003; Cardoso, D. A alma como centro do filosofar em Platão: uma leitura concêntrica do Fedro à luz da interpretação de Franco Trabattoni. São Paulo: Loyola, 2006; Trabattoni, F. A argumentação platônica. Revista Archai, n. 4, jan.-jun., 2010, p. 1-24. 
como aquele platônico que é desde sempre, mas com certa intensidade acrescida nas últimas décadas, um campo de debates hermenêuticos infindáveis, em que as novas propostas interpretativas recorrem em ritmo decenal.

O Autor percorre o caminho de Larissa das opinióes e lectiones contemporâneas com agilidade e consciência crítica, estruturando a presente obra como uma introdução ao mesmo tempo dos principais diálogos de Platão e de seus temas fundamentais. Assim, o método platônico, sua concepção metafísica, a complexa relação entre oralidade e escrita, os problemas epistemológicos que Platão levanta em sua obra se tornam momentos da construção de uma imagem coerente e, sobretudo, unitária do pensamento do ateniense. A preocupação com o leitor leigo e o aprendiz da filosofia é evidente na proposição de uma bibliografia comentada, que contribui para indicar os caminhos para o necessário aprofundamento da pesquisa.

Por todos esses motivos, e outros que o leitor atento poderá descobrir nas páginas a seguir, o Platão de Trabattoni, aqui traduzido e editado pela recéminaugurada Coleção Archai, vem certamente preencher uma lacuna editorial. Constitui-se, de fato, em um manual introdutório e propedêutico. Por esse motivo, amplamente acessível a um público leigo ao pensamento de um dos maiores pensadores, Platão; mas ao mesmo tempo escrito com a maestria de um autor que se encontra atualmente entre os mais reconhecidos intérpretes de Platão em nível internacional.

Brasília, abril de 2010 . 
(Página deixada propositadamente em branco) 


\section{VIDA E OBRA}

A VIDA

Dlatão nasceu em Atenas em 428/427 a.C.

1 Sua família pertencia à aristocracia econômica, intelectual e política da cidade. Recebeu uma educação de acordo com seu status, marcada sobretudo pela música (entendida como conjunto das disciplinas humanísticas e literárias) e pela ginástica. Além disso, grande importância deve ter tido para ele o contato com personagens cultas e influentes com as quais sua família mantinha relações (por exemplo, Crítias, que era seu parente). É difícil de avaliar o testemunho de Aristóteles, segundo o qual ele teria sido companheiro do heracliteu Crátilo. Pelo contrário, é certo que seu encontro decisivo foi com Sócrates, com o qual se relacionou até sua morte. A condenação de Sócrates 
teve decisiva importância na vida de Platão e marcou o início da sua verdadeira atividade filosófica.

Nas primeiras décadas do novo século, Platão realizou algumas viagens, mas sobre algumas delas (como a que fez pelo Egito e por Cirena) a tradição é incerta. Em vez disso, é mais provável que ele tenha frequentado as comunidades pitagóricas do sul da Itália (naquela ocasião ele pode ter conhecido Arquitas, o tirano pitagórico de Tarento), e é certo que foi por três vezes a Siracusa. A primeira vez foi em 388, convidado pelo tirano Dionísio, o Velho. No ano seguinte, de volta a Atenas, fundou a Academia, uma espécie de instituto de estudos superiores, onde se ensinava, estudava e conduzia uma vida em comum, dedicada quer a pesquisas, quer à formação de homens políticos e legisladores. Em 367, Platão foi outra vez a Siracusa, para verificar se o novo tirano, Dionísio II, o Jovem (que sucedeu ao pai), tinha verdadeiramente propensão para a filosofia como lhe garantira seu amigo siracusano, Díon: assim podia haver alguma esperança de criar condições apropriadas para a realização de um regime filosófico e bom. Foi, porém, uma experiência negativa. Todavia, Platão deixa-se convencer e decide repetir sua tentativa seis anos mais tarde. Mas também dessa vez falhou e, de fato, Platão conseguiu salvar-se somente graças à intervenção de Arquitas. Ao voltar definitivamente a Atenas, Platão passou o resto de sua vida escrevendo suas obras e ensinando na Academia, morreu em 348/347 a.C. 


\section{AS OBRAS}

A tradição legou-nos tudo aquilo que Platão escreveu e, além disso, transmitiu-nos também, sob seu nome, obras que não eram de sua autoria. Referimonos em primeiro lugar às chamadas Definiçôes e a seis diálogos que já os antigos consideravam espúrios. A restante obra platônica foi ordenada pelo gramático Trasilo, no início do século I d.C., em nove tetralogias, ou seja, em grupos de quatro, e essa estrutura é conservada também em muitas edições e traduções modernas. Desses 36 escritos, 34 são diálogos, um é um monólogo (Apologia de Sócrates) e outro é uma coletânea de Cartas. Mas nem todo esse material pode ser considerado autêntico. Das 13 cartas, de fato, talvez somente uma ou duas tenham sido escritas realmente por Platão (particularmente a VII, que é, sem dúvida, a mais interessante). Além disso, acredita-se que o Epinômide teria sido escrito por um discípulo seu, Filipe de Opunte. Muitas dúvidas também foram levantadas a respeito da quarta tetralogia (Alcibiades I, Alcibiades II, Hiparco, Os amantes), sobre o Clitofon, sobre o Téages e sobre o Hipias Maior. Mas consideramos que, ao menos o Hipias Maior e o Alcibiades I, devam ser considerados autênticos.

Os historiadores da filosofia sempre procuraram estabelecer a exata cronologia dos escritos platônicos (sob esse aspecto, a utilidade da ordem efetuada por Trasilo é insignificante). Com essa finalidade, foram tentados diversos métodos, dos empíricos (por exem- 
plo, estudos sobre a relevância da figura de Sócrates) aos quase científicos (como análises feitas ao computador do estilo platônico). Com base nessas pesquisas, conclui-se que a obra platônica pode ser dividida aproximadamente em três grupos: 1) Diálogos do primeiro período, predominantemente polêmicos em relação à cultura tradicional e à sofística, muitas vezes aporéticos (ou seja, em aparência incapazes de resolver os problemas propostos), muito ligados ao método e a temas dos ensinamentos socráticos; 2) Diálogos da maturidade, predominantemente construtivos, nos quais se reconhece a presença de verdadeiras doutrinas atribuíveis a Platão; 3) Diálogos da maturidade e da velhice, nos quais Platão se confronta, sobretudo, com difíceis problemas dialéticos (razão pela qual encontramos a classificação de "diálogos dialéticos" atribuída a alguns deles) e reelabora suas doutrinas políticas.

Segue um elenco de todos os diálogos, indicando resumidamente o assunto de cada um deles.

1. Apologia de Sócrates, onde é posto em cena Sócrates que se defende diante dos juízes; Criton, Sócrates no cárcere rejeita a proposta de fuga que lhe faz Críton; Eutífron, Lisis, Cármides, Laques, Hipias Maior, Mênon, primeiro livro d'A República: em todos esses diálogos, Sócrates conduz as investigações sobre um conceito de caráter geral, refutando as respostas de seus interlocutores. Esses conceitos são, na respectiva ordem, o santo (o sagrado), a amizade, a temperança (sophrosyne), a coragem, a beleza, a virtude e a justiça; Íon, que trata da poesia; Alcibiades I, sobre a prima- 
zia da alma e sobre a educação interior; Hipias Menor, onde se faz um confronto entre Aquiles e Odisseu; Górgias, no qual Sócrates dialoga com Górgias, Polo e Cálicles a respeito da natureza da retórica e sobre a felicidade do justo; Protágoras, Sócrates duela com o sofista sobre a natureza da virtude e sobre a possibilidade de educar à virtude; Eutidemo, no qual Platão contrapôe o modo socrático de fazer filosofia aos truques dialéticos dos sofistas menos sérios; Menêxeno, provavelmente uma paródia da retórica tradicional.

2. Crátilo, sobre a linguagem e os problemas gnoseológicos ligados a ela; Fédon, sobre a imortalidade da alma e a doutrina das ideias; Banquete, sobre o eros; A República, diálogo longo e denso, sobre o modelo ideal de estado e sobre os princípios metafísico-gnoseológicos que governam a realidade e o conhecimento; Fedro, sobre o eros, a ação da alma e a crítica à escrita.

3. Teeteto, sobre o relativismo protagórico e a natureza do conhecimento em geral; Parmênides, Parmênides expõe algumas críticas à doutrina das ideias e, em seguida, se embarca em um longo exercício dialético sobre o uno, o múltiplo e suas relações de reciprocidade; Sofista, o protagonista é o Estrangeiro de Eleia, que primeiramente se questiona sobre a natureza do sofista, depois estuda as características gerais do ser e do não ser; Filebo, sobre a vida boa e sobre suas raízes metafísicas (problema da relação entre uno-múltiplo, limite-ilimitado); Timeu, a geração providencial do cosmos, as características físicas da realidade e do homem; Crítias, incompleto, contém o mito de Atlântida; Político, definição do político e reavaliação da lei; 
Leis: é a última e mais longa obra de Platão, nela se descreve um estado ideal menos irrealista que o d' $A$ República (apesar de fundado sobre seus mesmos princípios) e se demonstra a ordem divina do cosmos.

Todas as traduçóes modernas da obra de Platão trazem no texto ou em suas margens a numeração das páginas segundo a fundamental edição de Henry Estienne, também conhecido por Stephanus (Lion, 1578): tal numeração é composta por um número, que corresponde à página, por uma letra, que corresponde a um parágrafo, podendo existir também eventualmente outro número (que indica a linha), para facilitar a identificação das passagens do texto, independentemente da edição ou da tradução que se utiliza.

\section{O DIÁLOGO PLATÔNICO}

Como vimos, os escritos de Platão são quase todos constituídos por diálogos; mas neles, o autor quase nunca aparece como personagem (na maior parte das vezes o papel de moderador é atribuído a Sócrates). Essa situação cria o problema de como saber reconhecer a opinião de Platão ou, até mesmo, de estabelecer se em determinada situação ele teria realmente uma opinião.

Um segundo problema é constituído pelo fato que, em dois pontos da sua obra (Fedro 277e-278b, Carta VII 341c), Platão parece criticar a escrita de modo tão radical que podemos até mesmo duvidar se ele teria realmente exposto nos seus escritos as suas opiniōes pessoais. A isto se acrescenta a existência de uma tradição 
indireta (derivada, sobretudo, de Aristóteles) que nos oferece uma série de doutrinas expostas oralmente por Platão na sua Academia (ver cap. 14). Como o conteúdo de tais doutrinas orais não corresponde, a não ser parcialmente, ao que se lê nos diálogos, não fica claro qual a relação que pode ser estabelecida entre as duas fontes, e qual deve ser o percurso mais viável para que se possa conhecer aquilo que Platão efetivamente pensava. E, sobretudo: com que objetivos Platão escreveu os diálogos?

Graças a uma passagem da Poética de Aristóteles sabemos que o "diálogo socrático" se transformou, ao longo do século IV, quase em um gênero literário autônomo (1447b). Isso é confirmado por documentos que possuímos: os Memoráveis de Xenofonte são a representação escrita das conversações socráticas (sejam elas verdadeiras ou não), e possuímos também vestígios de escritos análogos compostos por outros discípulos de Sócrates. É possível que essa literatura tenha surgido da exigência, compartilhada por muitos socráticos, de defender o mestre das acusações contidas em um famoso libelo que lhe dirigiu um certo Polícrates, em torno ao ano 390. Nesse caso, devemos acreditar que os discursos socráticos tiveram uma intenção tanto laudatória como descritiva.

Naturalmente, esse detalhe não deve ser excluído, sendo, aliás, evidente também em Platão. Mas não constitui uma resposta completa. De fato, é praticamente certo que a descrição de Platão não tenha como principal intenção uma fidelidade histórica e, em muitos casos, ele até mesmo não a respeita (a mes- 
ma coisa convém dizer dos discursos socráticos de outros autores). Acredita-se que, pelo menos nas obras da maturidade, Platão utilize a personagem Sócrates simplesmente como porta-voz de suas próprias ideias.

Com base nesses dados, formou-se o núcleo de uma solução ao problema do diálogo que podemos chamar "tradicional". No interior da obra platônica selecionam-se, em primeiro lugar, os diálogos juvenis que possuem, em sua maior parte, uma conclusão aporética, e afirma-se que seu escopo é reproduzir o método crítico-refutador do Sócrates histórico. Nos diálogos mais maduros, pelo contrário, a filosofia de Platão adquire um aspecto assertivo e doutrinal, que seria possível reconstruir selecionando e ordenando as afirmações da personagem que conduz a discussão: em primeiro lugar, Sócrates, mas não faltam também outros casos (como o Estrangeiro de Eleia, no Sofista e no Político, Timeu, no diálogo homônimo, e o Ateniense, nas Leis).

Essa hipótese certamente tem sua validade porque muitas vezes parece inevitável pensar que o que diz o condutor do diálogo é propriamente a opiniāo de Platão. Todavia, isso não vale como uma regra. Em primeiro lugar, não se entende porque Platão utilizaria a mesma personagem Sócrates como porta-voz em um caso de atitude aporético-cética e, em outro caso, de doutrinas positivamente afirmadas. Em segundo lugar, não parece haver uma plena coerência nem entre as afirmações das personagens que conduzem os diálogos assertivos. Por último, às vezes, a ativa colaboração dos deuteragonistas nos impede de crer que a 
“doutrina” platônica seja exposta exclusivamente pela personagem privilegiada.

Por causa dessas dificuldades, desenvolveu-se nas últimas décadas uma hipótese diametralmente oposta: Platão não se teria colocado como o protagonista de seus diálogos porque a intenção das suas obras era análoga àquela da poesia dramática (ou seja, descrever, como em um teatro, o encontro e o confronto entre determinadas posições), e não a exposição de suas teses pessoais.

Mas esta hipótese é menos aceitável que a hipótese oposta. Os diálogos platônicos não podem ser completamente comparados a obras teatrais ou a escritos puramente descritivos, mas no seu interior mostram ser bem dirigidos, propositivos, muitas vezes polêmicos, irônicos e até mesmo tendenciosos. Por detrás do texto, em suma, transparece a presença do autor, que constrói e sustenta com sabedoria o jogo do diálogo, fazendo explodir contradições, lançando sinais muitas vezes sutis e obscuros, sugerindo implicitamente ao leitor alguns percursos, contentando-se, por vezes, somente em confundi-lo para provocar nele determinadas reações. $\mathrm{O}$ autor, em outras palavras, é materialmente ausente do diálogo, mas bem presente do ponto de vista filosófico, como um invisível manipulador que move suas marionetes na cena para atingir determinados objetivos.

Essas observações nos levam à formulação de hipóteses que acreditamos serem mais plausíveis. É verdade que, nos diálogos platônicos, existe sempre uma personagem que dirige a discussão e que se apresenta 
mais hábil e mais sábia que as outras. Mas é preciso ter atenção e não confundir a comunicação que vai do protagonista do diálogo ao seu interlocutor com a comunicação que vai do autor ao ouvinte (na Grécia Antiga os "livros" eram, na maioria das vezes, lidos em voz alta e em público). Aquilo que Sócrates diz a uma certa personagem no diálogo, de fato, não significa necessariamente aquilo que o autor quer dizer a quem lê o seu texto.

Para encontrar o pensamento de Platão nos diálogos não basta somente seguir algumas afirmações, mesmo que se trate de afirmaçóes de Sócrates (e dos outros condutores). Em vez disso, faz-se necessário analisar no seu todo a estrutura dialógica, composta quer por perguntas, quer por respostas dos interlocutores, tentando assim entender o que Platão queria dizer ao leitor ao construir um certo tipo de diálogo, no qual, quem interroga formula certas perguntas, e quem responde o faz de maneira bastante calculada. O resultado do texto é sempre a soma desse entrelaçamento; e pode acontecer, com grandes chances, que a contribuição do interlocutor seja pouco relevante, podendo também acontecer (e com chances ainda maiores), que o sentido de um determinado desenvolvimento dialógico ultrapasse largamente as asserções dos dialogantes. 
Esclarecido esse ponto, passamos agora ao problema da crítica da escrita e àquele relativo às doutrinas orais (que, diga-se de passagem, está intimamente ligado ao primeiro). Também nesse caso, a história dos estudos platônicos apresenta-nos um conflito entre duas posiçōes opostas. A visão tradicional minimiza tanto as passagens em que Platão se distancia da escrita (diz-se, por exemplo, que esta precaução não se preocupa especificamente com a forma da obra platônica, ou seja, o diálogo), como os testemunhos indiretos (nesse caso, tratar-se-ia de interpretaçóes incorretas de Aristóteles, que, além do mais, atribuiria a Platão doutrinas de outros alunos da Academia).

Exatamente contrária é a opinião de outros estudiosos (referimo-nos, sobretudo, à chamada "escola de Tubingen-Milão") que defendem que Platão teria propositadamente reservado suas doutrinas mais elevadas e importantes ao ensinamento oral, deixando aos diálogos um papel de caráter introdutório e/ou de divulgação. Isso ocorreria porque a palavra escrita não é capaz de escolher seus destinatários e corre um grave risco de não ser compreendida, porém há conteúdos que podem ser revelados apenas àqueles que possuem já uma preparação específica. O corolário desta tese é que os diálogos podem ser compreendidos completamente só à luz das doutrinas que Platão ensinava na Academia, mas são doutrinas que nós, de alguma forma, possuímos por meio da tradição indireta. 
Notaremos, outra vez, que as posições extremas dificilmente são fiáveis. Àquela interpretação que chamamos de tradicional, pode-se objetar que um ensinamento oral de Platão por certo deve ter existido, que os testemunhos de Aristóteles não podem ser simplesmente desqualificados e que as críticas à escrita, assim como foram formuladas, dificilmente possam excluir o diálogo. Contra a tese segundo a qual Platão não teria colocado por escrito os pontos cardeais do seu pensamento, deve-se dizer que a contraposição, em Platão, entre a oralidade e a escrita, não possui (ou não possui somente) o objetivo contingente de dividir as doutrinas entre coisas que poderiam ser ditas a todos e coisas que poderiam ser ditas somente a alguns. De fato, na preferência que Platão manifesta pela oralidade é determinante um motivo de caráter filosófico: o mesmo que impulsiona Platão a escrever diálogos de maneira anônima, a dedicar um largo espaço da sua obra a um Sócrates que age de modo crítico-cético e a disseminar nas suas páginas omissões, contradiçôes e fórmulas de cautela.

Aquilo que entra em jogo nesse problema, em suma, é a presença constante da influência de Sócrates na filosofia de Platão. A presença obsessiva na obra platônica da figura de Sócrates e de seu método dialógico-refutatório testemunha a continuidade de pensamentos que se revelam pela maiêutica e pela busca interior: o saber nasce e se desenvolve no interior da alma de cada um. Os meios externos, consequentemente, podem ter, na melhor das hipóteses, a função 
de estimular e favorecer esse nascimento. Logo, resulta pouco interessante articular o saber filosófico em tratados sistemáticos e impessoais, como se se tratasse de uma ciência única e igual para todos. Ao invés, o instrumento mais eficaz é o colóquio oral, como o que Platão realizava diretamente com seus discípulos. Mas, na falta de uma situação mais adequada, ou seja, quando é possível chegar ao interlocutor somente por meio do texto escrito, o melhor modo de se aproximar do colóquio oral é o diálogo. O diálogo compromete, antes de tudo, Sócrates e os outros protagonistas das conversaçôes platônicas; mas envolve ativamente também o leitor, que, a partir do texto assim construído, obtém estímulos para a investigação pessoal com muito maior eficácia do que as que poderia extrair da exposição de uma doutrina.

\section{EXISTE UMA EVOLUÇÃO NO PENSAMENTO PLATÔNICO?}

As observaçôes que expusemos fornecem-nos bases para dizer algo sobre o tema da evolução da filosofia de Platão.

Houve um tempo em que se pensava em resolver as incoerências presentes na obra de um filósofo mostrando que ele havia mudado de ideia ao longo do tempo. Mas hoje esse critério evolucionista está um tanto quanto desfasado, ou se se quiser, é filosoficamente irrelevante; de fato, não explica os motivos teó- 
ricos da mudança, os únicos que interessam verdadeiramente ao filósofo.

Além disso, para Platão, as incongruências a serem resolvidas - e que às vezes trazem de volta a questão da evolução - resultam tais apenas com base em interpretações que não dão conta das características típicas do diálogo platônico, do qual falamos anteriormente: com efeito, só se o Sócrates platônico coincidir com Platão, é possível atribuir diretamente ao autor suas supostas contradições.

Mas a evolução é colocada em campo também para resolver outro problema, isto é, o contraste entre a aporicidade dos diálogos juvenis e a conclusividade daqueles mais maduros (ou pelo menos da maior parte deles). Diz-se que o jovem Platão era ainda próximo à indagação socrática e incerto sobre a forma de resolver os problemas colocados pelo mestre, e só depois teria realizado uma mudança em sentido assertivo-dogmático.

Mas também essa posição cai no mesmo erro anterior, ou seja, o de menosprezar as razóes dialógicosocráticas. Em primeiro lugar, não é nada certo que as dificuldades do protagonista Sócrates sejam as mesmas dificuldades do autor do diálogo. Sobretudo, não é verdade que na obra de Platão se contraponham um Platão aporético/socrático e um Platão dogmático. É verdade que há diálogos nos quais os problemas são resolvidos e outros em que não são. Mas, na realidade, nenhum diálogo, se for interpretado com o método global que propusemos, é tão aporético ao ponto de não propiciar nenhum avanço nas investigações ou de não sugerir, pelo menos de forma implícita, um certo 
tipo de solução; e nenhum diálogo é de tal forma conclusivo ao ponto de mostrar soluçóes nele proposta como verdadeiras, absolutas e definitivas.

\section{PLURALIDADE DE MÉTODOS}

Tudo aquilo que sugerimos nos conduz à conclusão de que, nos escritos platônicos, a forma e o conteúdo estão tão harmonicamente entrelaçados que se torna bastante difícil separá-los: à natureza da pesquisa filosófica, nunca definitivamente concluída e sempre aberta a ulteriores aprofundamentos, corresponde uma modalidade expressiva dúctil e não dogmática, como a do diálogo.

Essa impressão é confirmada também pelo fato de Platão, nas suas obras, ter feito uso exaustivo do mito. Mas não se trata de um mito entendido no sentido tradicional, como palavra de autoridade que precede o uso do logos (e eventualmente lhe faz concorrência). Pelo contrário, Platão constrói seus mitos para representar de modo não dogmático ou doutrinal conteúdos de caráter filosófico. Existe até mesmo uma passagem d'A República (501e) na qual a exposição das importantes doutrinas políticas ali contidas é qualificada sem qualquer dúvida como mythologhein (contar mitos). Nos diálogos platônicos, as canônicas divisões entre mito e logos, entre demonstração e persuasão, entre lógica, dialética e retórica, são sempre um tanto quanto indefinidas e esse fato torna pouco frutífero 
agredir suas páginas com métodos científicos no intuito de se estabelecer quando estamos verdadeiramente diante de doutrinas rigorosamente fundadas. A isto se acrescenta o uso frequente da ironia, elegante mistura de sério e jocoso, suportada pela persuasão, tanto que, às vezes, o melhor modo para se aproximar da verdade é justamente utilizar como veículo a palavra leve da brincadeira, da metáfora ou do conto. Em suma, Platão estava persuadido de que a filosofia é uma coisa demasiadamente séria e importante em nossas vidas para podermos reduzi-la a uma sequência bem concatenada de asserçōes.

Por fim, não devemos acreditar que é o modo pelo qual Platão distribui suas formas de expressão a documentar uma sua evolução em direção ao dogmatismo. De fato, Platão articula o uso desses instrumentos em função do objetivo que se propõe: se a intenção é criticar um sofista, o método crítico-refutatório é o mais eficaz; se é argumentar a favor de um determinado princípio moral, o diálogo assume uma dinâmica propositiva; se, pelo cotrário, se pretende tratar de coisas imponderáveis e impalpáveis, como o destino das almas depois da morte ou as origens da civilização, é o mito o instrumento mais indicado. Com isso, não pretendo negar que, ao longo do tempo, a filosofia de Platão tenha sofrido uma mutação. Quero dizer apenas que se trata, em sua maioria, de mudanças não substanciais, e, que, sobretudo, essas mudanças não devem ser evocadas na intenção de resolver problemas de caráter filosófico. 


\section{SÓCRATES E PLATÃO: \\ A ORIENTAÇÃO ÉTICA \\ E POLÍTICA}

\section{O ENCONTRO COM SÓCRATES}

Dara introduzir a filosofia De Platão, o
procedimento mais útil que podemos adotar
parece ser começar pela Carta VII (eu parto do pres-
suposto, amplamente aceito pela crítica, de que seja
autêntica). Platão escreve esse texto, já em idade avan-
çada, com a intenção de justificar à opinião pública
ateniense seu projeto em relação aos fatos acontecidos
por ocasião de sua ida à Sicília. Ao compor essa sua
"defesa”, Platão revela ao leitor fatos preciosos sobre as
circunstâncias e as motivações que o fizeram seguir o
caminho da filosofia.
Vindo de uma família aristocrática, instruído e
educado da melhor maneira possível, o jovem Platão
considerava a atividade política como a finalidade na- 
tural da sua vida. Depois da queda do governo democrático (no verão de 404), ele se aproxima com interesse do governo filoespartano dos Trinta Tiranos, no qual participaram alguns de seus familiares e conhecidos (por exemplo, seu tio por parte de mãe, Crítias). Platão esperava que o novo governo "reordenasse a cidade, conduzindo-a da injustiça a um modo justo de viver" (324d). Mas a desilusão foi pungente. As más ações dos novos governantes de Atenas foram tantas e tais que "em pouco tempo fizeram com que o governo precedente parecesse um paraíso". Como exemplo emblemático, Platão cita um episódio relativo à vida de Sócrates (por ele definido como "o homem mais justo daqueles de seu tempo", 324e), isto é, a tentativa frustrada, por parte dos Trinta Tiranos, de tornar o filósofo cúmplice do assassinato de um homem. Pouco depois de um ano, quando o regime dos Trinta Tiranos caiu e se restabeleceu a democracia, Platão sentiu de novo o desejo de ocupar-se da coisa pública. Mas ele foi desviado dessa intenção por causa do processo e da condenação de Sócrates à morte: o regime democrático que, no fundo, havia se mostrado tolerante, estava acusando de impiedade justamente o homem que, para não parecer ímpio, se recusara a ser cúmplice dos tiranos (325c).

Platão nos mostra que, no ato em que escolheu os objetivos que deviam direcionar sua existência, essa vicissitude socrática desempenhou um papel determinante. Ele considerava altamente significativo o fato de a grande integridade moral de Sócrates ter sido mais de uma vez contraposta à práxis política impura 
vigente na Atenas do século V. Decidido a fazer filosofia continuando o trabalho de Sócrates e com os olhos concentrados sobre os negativos resultados da prática ética e política vigente da sua cidade, Platão inaugura então uma ideia de filosofia na qual o saber que se procura (lembremos que a palavra "filosofia" significa "amor pela sabedoria") não é só um saber que se encerra em si mesmo, voltado para o puro conhecer, mas é um saber que pretende identificar aqueles princípios gerais fundamentais, os únicos que podem promover o bem-estar do homem (ou seja, sua felicidade), tanto na vida privada como na vida pública.

Sem dúvida, Platão percebeu que, para seguir bem as pistas dessa investigação, ocorria fazer referência a contextos teóricos que ultrapassassem o terreno puramente ético e que dissessem respeito à natureza da realidade e à determinação dos seus princípios. Mas nunca devemos esquecer que essa investigação serve, antes de tudo, para encontrar pontos de referência úteis para estabelecer as condições de uma vida boa, privada e pública. Esse tipo de orientação esclarece algumas características importantes da filosofia de Platão, entre elas, a relativa pobreza, encontrada na sua obra, de doutrinas ontológicas ou metafísicas propriamente ditas, e a substancial falta de sistematicidade do corpus platônico (no qual é difícil detectar uma estrutura doutrinal que se reproponha de forma idêntica, ou ao menos similar, diálogo após diálogo). Platão, de fato, não se preocupa muito em descrever de modo detalhado e coerente a natureza dos princípios, mas se satisfaz muito mais em mostrar a existência de princí- 
pios de um certo gênero: a saber, aquele gênero que seja útil para fundar a práxis ética e política.

\section{FILOSOFIA E VIDA}

Um dos principais legados que Sócrates deixou a Platão foi a estreita ligação entre filosofia e vida. Por duas vezes, ao longo dos diálogos (Górgias 500c, $A$ República 352d), o Sócrates de Platão explica que o argumento sobre o qual se discute é extraordinariamente importante porque trata de "como se deve viver". Portanto, nenhum homem pode verdadeiramente se declarar indiferente à filosofia, porque seria como se declarasse o próprio desinteresse pela felicidade. Ao passo que Platão parte do pressuposto - diga-se de passagem, muito comum em todo o pensamento grego - de que todos os homens desejam ser felizes (ver Eutidemo 278e, 282a), e que esta verdade não admite exceçôes.

Também nesse ponto a herança socrática é decisiva para Platão. Ele se apropria dos princípios fundamentais da moral socrática e, de certa maneira, dispóe-se a expô-los e articulá-los de maneira clara, ao longo da sua obra (lembremos que Sócrates não escreveu nada e que, por esse fato, muito do que sabemos dele chega a nós justamente por meio de Platão). Segundo esse tipo de ética, que podemos chamar de socrático-platônica, não só todos os homens desejam por natureza ser felizes, mas também não há nenhum motivo que 
possa legitimamente contrapor-se a esse impulso. Isso significa que não deve e não pode existir uma situação na qual os impulsos que conduzem os homens à conquista da felicidade se movam em uma direção contrária àqueles que solicitam o cumprimento de um certo dever moral. Ou melhor, podemos dizer que, neste contexto, o conceito de "dever moral", de fato, não existe a consequência disso é que, se se desejar promover comportamentos éticos virtuosos e não viciosos, o único modo possível para cumprir essa tarefa é mostrar que a felicidade só pode ser alcançada por meio da virtude, enquanto o vício produz o efeito contrário.

Platão tenta cumprir esse programa sobretudo no Górgias e n'A República. Emblemática, particularmente, é a discussão que ocorre entre Sócrates e Cálicles no primeiro desses dois diálogos. A tese de Cálicles é que a felicidade reside na multiplicação indiscriminada dos desejos e na sua completa satisfação. Consequentemente, entre os homens, o mais feliz será o tirano, porque pode se permitir fazer tudo o que quiser: poderá matar, roubar, torturar, estuprar apenas para seu próprio prazer e sem sofrer nenhuma sanção (491e-492c). Ao contrário, Sócrates opõe a Cálicles a tese, segundo a qual é melhor sofrer uma injustiça do que cometê-la. Dados os pressupostos da ética socrático-platônica, ele não pode, todavia, demonstrar essa tese em um plano abstrato das regras e dos princípios. Não pode dizer, por exemplo, que não se deve roubar, por mais que uma ação desse gênero possa ser gratificante. Ao contrário, ele deve mostrar que a injustiça deve ser banida justamente devido à única regra que, no interior dessa 
ética, é universalmente válida, ou seja, que a injustiça causa infelicidade a quem a pratica (505b).

A tarefa é, sem dúvida, muito difícil, e Platão se esforçará ao máximo para realizá-la n'A República. Mas disso falaremos em momento oportuno (ver cap. 10, pp. 212sqq.). Agora é importante salientar que esse estado de coisas implica a verdade dos chamados paradoxos da ética socrática, ou seja, que ninguém cumpre o mal voluntariamente e que a virtude consiste em conhecer. Dizer que ninguém cumpre o mal voluntariamente não significa dizer que o mal é sempre cumprido involuntariamente (como acontece, por exemplo, quando querendo pegar um objeto e sem querer esbarramos em alguém). Significa dizer que o mal produz sempre infelicidade e que, portanto, uma ação malvada confere, a quem a comete em todos os casos, algo que o sujeito "não deseja" (neste sentido falamos de involuntariedade), porque, como vimos, ninguém foge à regra de desejar a própria felicidade. Disso resulta também que a virtude é conhecimento: não tanto no sentido de que seja feliz quem exerce uma atividade teorética, quanto no sentido que a virtude coincide com o conhecimento daqueles princípios que, quando aplicados, fazem o homem ser feliz. Logo, a virtude é aquele tipo de conhecimento que constitui o meio para que possamos alcançar a felicidade. Desse modo, confirma-se a noção de filosofia de que falamos antes, uma filosofia entendida como atividade teórica que tem por finalidade orientar corretamente a ação. 
Se o mal produz sempre a infelicidade, e se é verdade que todos os homens desejam ser felizes, deduzse como consequência lógica que o conhecimento do bem será condição necessária e suficiente para o homem alcançar a felicidade. É condição necessária, porque se não se sabe como encontrar a vida boa, será muito difícil alcançar esse objetivo. Mas é condição suficiente porque, uma vez conhecidos com certeza os meios de se alcançar a felicidade, e não tendo o homem outros empecilhos que disturbem sua ação, as próximas ações serão executadas de modo mecânico e automático.

Aqui Platão utiliza um modelo teórico extraído do âmbito das técnicas que muito permeia suas reflexôes. Em qualquer técnica artesanal, quanto maior for o conhecimento teórico de um artesão, melhor será seu produto. Ora, Platão está convencido de que, mesmo com as limitaçôes que veremos adiante, a ética e a política comportam-se exatamente como técnicas. Assim como a técnica arquitetônica é um saber capaz de proporcionar, para quem a domina, bons edifícios, da mesma forma, a filosofia é um saber capaz de proporcionar a boa vida para quem a conhece. Eis porque, para Platão, possuir uma teoria correta e, imediatamente, o exercício de uma boa filosofia, é muito importante: porque é a condição necessária e suficiente para que possa ser realizado o bem na vida pública e privada.

O quadro que descrevemos implica que a realização da vida boa seja dependente da existência de valores universais como o bem (ou o justo) e da hipótese 
que exista um saber (ou melhor, uma filosofia) capaz de conhecê-los. Mas essa tese está sujeita a duas importantes objeções. Em primeiro lugar, poderíamos observar que os valores universais não são objetos de tratamento filosófico, e sim concedidos aos homens pela divindade, pelos costumes ou pela tradição. E, em segundo lugar, de maneira ainda mais radical, poderíamos dizer que os valores universais nem mesmo existam, quer porque cada um de nós possui seu modo pessoal de conceber a felicidade (e todos são legítimos), quer porque as próprias noções de "bem" e de "justo" podem variar entre determinados grupos e indivíduos. Essas duas objeçôes correspondem a dois desafios que Platão teve de enfrentar durante a elaboração do seu pensamento: a primeira visa a cultura tradicional e a segunda a sofística (particularmente a protágorica). Falaremos disso nos próximos dois capítulos. 


\title{
A CRÍTICA À CULTURA TRADICIONAL
}

\author{
A "IGNORÂNCIA" \\ DA CULTURA TRADICIONAL
}

\begin{abstract}
O evento do processo a Sócrates está presente de vários modos em mais de um diálogo platônico: não somente na Apologia e no Críton, mas também no Eutífron, no Fédon, e, esporadicamente, encontram-se alusóes também em outros escritos (por exemplo, no Górgias). Entre outras coisas, recapitular esse fato significa para Platão instituir um confronto entre a cultura tradicional, de onde vinha a maior parte das acusações a Sócrates, e a nova concepção ética introduzida pelo próprio Sócrates, raízes nas quais Platão queria enxertar o seu proprio projeto filosófico. Conta Sócrates, na Apologia, que o oráculo de Delfos teria certa vez dito, interrogado por Querofonte,
\end{abstract}


que na Grécia não existia um homem mais sábio do que ele (20e sqq.). Sócrates, para averiguar o fundamento dessa revelação, começou a examinar todos aqueles que na cidade possuíam fama de serem sábios, particularmente políticos, poetas e artesãos. O resultado dessas análises foi desconfortante: enquanto políticos e poetas pensam que sabem, mas no fundo não sabem nada, os artesãos demonstram realmente saber alguma coisa (a respeito dos procedimentos de sua arte). Todavia, eles demonstram a ambição de saberem coisas além das regras da sua profissão e mais importantes (dos princípios da ética e da política), mas na realidade também não sabem nada. Em contraposição a esse impasse, figura o modesto, mas sólido saber de Sócrates, porque, mesmo sendo também um ignorante como todos os outros, pelo menos sabe que nada sabe (21d). Para Platão, dessa situação emerge aquilo que ele considerava ser o defeito mais grave da cultura vigente: a ignorância de quem pensa que é sábio e não é, e com base nessa pretensão infundada acredita ter o direito de promover (quando não de impor) determinados princípios e modos de comportamento.

Mas o que podemos entender por "cultura tradicional"? Como nos diz um célebre fragmento de Xenófanes, "tudo que os Gregos sabem, aprenderam de Homero" (fr. 9 D.-K.). Os poemas homéricos constituíam para os Gregos não somente um texto básico para a aquisição dos primeiros conhecimentos linguísticos, mas também representavam a principal fonte religiosa, jurídica e moral. Dessa situação nasce uma cultura que alguns estudiosos chamaram de "épico- 
homérica”, na qual constantemente eram exaltados os cultos à coragem, à força, à honra; elogiavam-se os empenhos patrióticos, o respeito aos anciãos, a cordialidade com relação aos hóspedes e amigos; mas também a capacidade de se fazer respeitar, de punir os inimigos, e por intermédio de suas próprias atitudes obter poder e prestígio na sociedade. Esse modelo cultural era legitimado pelo comportamento dos próprios deuses olímpicos, que não faziam nada diferente do que os homens, o que oferecia uma cômoda justificação para as açôes dos homens: paixões como a luxúria, a ira, a cobiça eram comuns também aos deuses de Homero, e por isso poderiam ser entendidos como aspectos lícitos e característicos da natureza humana.

Antes de tudo, poetas e homens políticos eram para Platão importantes expoentes da cultura tradicional. Em diálogos como o Górgias ou A República, Platão expóe sua crítica de um modo direto, agindo no plano dos valores e dos conteúdos. Já na Apologia, no Ion e no Mênon, encontramos sinais de uma estratégia mais neutra, além do mais, cônsona ao método refutador de Sócrates: sem entrar no mérito dos produtos daquela cultura (sejam textos poéticos ou procedimentos políticos), e admitindo-se pelo menos provisoriamente que tais produtos são bons, Platão se limita a mostrar que os autores dessas coisas "boas" as teriam realizado sem ter o verdadeiro saber. Isso basta para provar que poetas e políticos não possuem nenhum direito de assumir posiçôes normativas no interior $\mathrm{da}$ sociedade, enquanto que quem tem direito para estabelecer as normas e, por conseguinte, ensinar quais são 
os valores, é somente aquele que dispõe propriamente do saber (na justa medida em que dispóe dele).

Esta presença simultânea de capacidade eficaz de produzir coisas boas juntamente com a ignorância do procedimento com o qual se obtêm esses resultados é tratada por Platão, de um lado, a respeito da poesia, pela noção tradicional de "inspiração ou dote divino", e, do outro, através do grau gnoseológico da "reta opinião".

No Ion (533d-535a), Sócrates confia aos poetas (assim como aos rapsodos que os repetiam) a inspiração divina. Mas este reconhecimento não deve ser encarado tão seriamente. Aquilo que importa para Platão na concepção de inspiração é o fato que o poeta, quando compõe, se comporta como um profeta (segundo a etimologia do termo), ou seja, como alguém que fala em nome de outro; e é claro que este outro, em nome de quem ele fala (a divindade), para que possa se servir do poeta como um canal fiável e não deformante, deve anular sua mente e sua capacidade pessoal de elaboração. Logo, o poeta, se inspirado pelas Musas, por definição, não possui nenhum saber propriamente dito; consequentemente, sua pretensão a um papel normativo deve ser considerada nula.

Por trás dessa ideia, expressa no Íon, de que os poetas são dotados de uma inspiração divina, não se deve ver uma tomada de posição a favor, mas deve ver-se uma maneira para dizer que eles são indivíduos tocados pela fortuna, e que de um modo ou de outro quase sempre acertam, mesmo que suas (eventuais) revelações muitas vezes não dependam de um saber propria- 
mente dito. Nesse sentido, a inspiração divina resulta totalmente análoga, como podemos ver no Mênon, ao grau de conhecimento que Platão chama de "reta opinião”. Lemos, nesse diálogo, que a reta opinião não se distingue do saber sob um plano prático (no sentido de que tanto quem possui reta opinião quanto quem possui um saber pode produzir bons resultados), mas, sim, sob um plano teórico: somente quem sabe é capaz de dar provas (logon didonai) de seus sucessos, não basta somente possuir uma reta opinião (97a-98b). Por exemplo, pode acontecer até a quem não é médico de saber que uma aspirina pode fazer baixar a febre, mas somente um médico saberá dizer porquê. Logo, só um médico saberia, além de curar o paciente, também ensinar a medicina.

Antecipamos já anteriormente a conclusão desse discurso. Se aplicarmos o exemplo "técnico" da medicina àquela técnica muito mais importante que é a política, concluiremos que somente aquele que possui algum saber a respeito do que é o bem e o mal pode exercer uma função normativa, e não aquele que é capaz, feliz e ocasionalmente, de fazer ou dizer coisas boas (como os poetas e políticos tradicionais).

\section{O FORMALISMO ÉTICO-RELIGIOSO: EUTÍFRON E CÉFALO}

De fato, Platão não insiste muito em aceitar, como parece fazer na Apologia, no Íon e no Mênon, que a 
cultura tradicional possa produzir de verdade coisas boas. É bem mais realista pensar que à ignorância do processo produtivo corresponda também a negatividade dos conteúdos. Por isso Platão desenvolve seu ataque à cultura tradicional em ambos os pontos, ou seja, denunciando quer a ignorância dos seus expoentes, quer a má qualidade de suas produçôes. Para ilustrarmos este modo de agir, examinaremos algumas passagens do Eutifron e d'A República.

Eutífron se dirige ao tribunal para apresentar uma acusação a seu pai e, nas escadas, encontra Sócrates. Um colono do pai de Eutífron, em estado de embriaguez, matou um escravo da casa. O pai de Eutífron o aprisiona em um buraco e envia outro funcionário a Atenas para saber como deveria proceder. Enquanto isso, o colono assassino morre, devido às precárias condições do seu aprisionamento. Aparentemente Eutífron parece ter razão, tanto é que seu argumento de defesa poderia suscitar a simpatia do homem de hoje (4b-c): ao avaliar um assassinato, a condição da vítima não tem importância, porque aquilo que mais importa é saber se o assassino teve razão ou não em matar (por exemplo, por legítima defesa).

Mas se lermos em profundidade suas justificativas, descobrimos o quanto é arcaica e imatura a concepção ética do jovem sacerdote. Eutífron defende que, aquele que vive sob o mesmo teto de um assassino acaba sendo "contaminado", seja quem for o assassino (4c). É quase inútil dizer que o conceito de contaminação pertence a antiquados modelos eticorreligiosos, dos 
quais não importa tentar descobrir o que seria o mal ou o bem, importa somente o fato exterior e mecânico do contato com o objeto, ou com a pessoa impura. Segundo essa mentalidade, se, acidentalmente, invadirmos um local sagrado, podemos ser amaldiçoados por deus, sem que a suposta invasão indique a responsabilidade consciente do agente.

Erraríamos se explicássemos a fragilidade da posição de Eutífron com base em um particular defeito da personagem. Pelas características humanas de suas personagens, Platão quer representar (e criticar) não tanto e não somente personagens históricas, mas, também, e, sobretudo, um modo geral de pensar e de se comportar. De fato, Eutífron não parece ser uma pessoa má. Nas primeiras frases do diálogo, quando Sócrates lhe expóe os motivos pelos quais ele estava sendo condenado (Sócrates estava indo ao tribunal para tomar conhecimento da acusação, que depois levaria a seu processo), o sacerdote fica logo do seu lado, e elabora considerações razoáveis até mesmo aos ouvidos de nós modernos. Convém não esquecer notar que Sócrates aparece provocador, quando parece considerar incoerente que se possa querer condenar um parente a favor de um estranho (4b). O defeito de Eutífron é de ordem geral, não pessoal: no diálogo ele é representado como o típico expoente da cultura tradicional, que crê ser sábio sem sê-lo, porque baseava seu comportamento não em um verdadeiro conhecimento daquilo que é o bem, mas em um vazio formalismo privado de uma real relevância ética. 
Isso nos permite aproximar Eutífron de outra personagem platônica muito mais exemplar da cultura tradicional, e que Platão apresenta sem a deixar ser refutada ou criticada pelos outros. Refiro-me ao velho Céfalo, que figura nas primeiras páginas d'A República. Sócrates, percebendo sua grande serenidade, pergunta-lhe como conseguia suportar a sua velhice, sugerindo que o motivo dessa serenidade teria qualquer relação com sua riqueza. Céfalo nega que esse aspecto seja essencial, mas admite que esta sua cômoda situação lhe permitia não cometer ações injustas contra ninguém, não mentir ou enganar, e dado que não tinha acumulado débitos nem com homens nem com deuses, não temia os juízos divinos que provavelmente lhe esperariam depois de sua morte (330d-331b).

Logo, o retrato de Céfalo parece positivo. No entanto, sua concepção ética parece, para Platão, tão errada quanto a de Eutífron. Céfalo é um anciāo, e por isso começa a ter medo do juízo divino. Mas sua boa consciência o conforta. Por outro lado, o fato de nunca ter passado dificuldades materiais o teria ajudado a manter essa boa consciência. Isso significa que, para Céfalo, exatamente como para Eutífron, existem circunstâncias externas que podem contribuir para sua bondade ou maldade, ou melhor, podem decidir sobre sua inocência ou culpa. É significativo que Céfalo considere enganos ou mentiras "não voluntários" uma possível causa de culpa.

Mas voltemos ao Eutífron. O resto do diálogo demonstra que o sacerdote compartilha alguns precon- 
ceitos importantes, típicos da cultura que representa. De fato, explica Eutífron, que quem o culpa de cometer uma ação ímpia, na verdade não conhece a norma divina do que é piedoso e do que é ímpio (4e). Essa declaração oferece a Sócrates a oportunidade para interrogá-lo a respeito da natureza intrínseca dos temas de que discutem. É notório que Sócrates iniciava o interrogatório a seus interlocutores perguntando "o que é?" uma determinada coisa, esperando receber uma resposta que pudesse valer universalmente para todos os casos. Ele pergunta, por exemplo, "o que é a justiça?", "o que é o belo?”, “o que é a coragem?” etc.; nesse caso, discute-se "o que é santo?” (ou talvez seja melhor dizer, o "sagrado?").

Eutífron declara saber o que é o santo, mas logo em seguida demonstra ser incapaz de defender a sua posição. Ele inicia dizendo que é santo cumprir ações como aquela que ele está cumprindo, sem se distrair por motivações contingenciais (como por exemplo, a relação pai-filho). E, para sustentar sua posição, cita o exemplo mitológico de Zeus, o melhor e mais justo de todos os deuses, que acorrentou seu pai Crono por ter cometido uma injustiça, tal como Crono, por sua vez, também com razão mas com motivos diferentes, mutilou seu pai Urano (5d-6b).

Essa resposta não pode satisfazer Sócrates, quer porque, para ele, esse tipo de histórias não parecem críveis, quer porque se limita a indicar somente um exemplo, um caso particular, e não diz o que é o santo em si. Assim Eutífron sugere outra solução: santo é 
aquilo que agrada aos deuses (mas para evitar futuras dificuldades, logo reformula dizendo que é "aquilo que agrada a todos os deuses”, 9d). É nesse ponto que Sócrates coloca o problema fundamental: o santo é santo porque os deuses o amam, ou os deuses amam aquilo que é santo porque é santo em si? Sócrates demonstra que pelo fato de uma coisa sofrer a ação de ser amada pelos deuses se pode extrair somente a condição de que a coisa é "querida" aos deuses, e nada mais. Então, a sequência correta é a contrária, segundo a qual os deuses amam aquilo que é santo em si (9e-10e). Consequentemente fica claro que a definição proposta por Eutífron não acertou no alvo, e que suas referências aos deuses não o ajudaram em nada.

Não acrescentaremos outros detalhes e não analisaremos o desenvolvimento ulterior desse diálogo. $\mathrm{O}$ que importa mostrar é que Eutífron, quanto à religião, segue aquilo que poderíamos chamar "princípio de autoridade". Dizendo que "santo" é aquilo que agrada aos deuses, ele faz uma explícita referência a um conjunto de princípios e de verdades comumente consolidados (pela tradição e pela poesia), não se preocupando em questionar se esses princípios são aceitáveis ou não. Para Platão esse era um clássico caso de ignorância mascarada de sabedoria, e dos mais perigosos, porque o pretenso saber alardeado pelos sacerdotes e poetas tornava-se cada vez mais padrão moral para a vida cotidiana. Entendemos bem a razão pela qual, para Platão, contrastar a cultura tradicional tinha uma importância absolutamente decisiva. Não se trata tanto de contrapor uma 
visão do mundo a outra: trata-se, muito mais radicalmente, de abrir espaço para a filosofia.

\section{A CRÍTICA DA CULTURA TRADICIONAL NO SEGUNDO E NO TERCEIRO LIVROS \\ D'A REPÚBLICA}

Ambos os motivos que ilustramos (o formalismo exterior da religião tradicional e a sua apelação à autoridade de um mito privado de significado ético) são retomados no segundo livro d'A República. Trata-se de um texto ao qual retornaremos mais adiante. Nesse momento, é suficiente mencionar as teses provocatórias de Gláucon e Adimanto (os dois irmãos de Platão que nesse diálogo discutem com Sócrates) a respeito da religiâo. Gláucon sustenta que o injusto, enriquecendo com as suas malvadezas, poderá cumprir sacrifícios mais esplêndidos que o homem honesto, por isso, será mais querido pelos deuses e poderá conquistar melhor seus favores (362c). Adimanto recorda antes de tudo que sacerdotes e adivinhos convencem facilmente as pessoas de que possuem uma habilidade deprecativa, capaz de, mediante feitiços e fórmulas mágicas, colocar os deuses a seu serviço; e, a propósito disso, cita o testemunho de Homero e dos mais antigos poetas e profetas como Museu e Orfeu (364c-e). De posse dessa arte, homens maldosos têm a possibilidade de cometer injustiças sem temer puniçôes por parte dos deuses, os únicos aos quais suas açôes não podem per- 
manecer ocultas. De resto, se acreditamos nos deuses pelas obras dos poetas que deles nos falaram (aqui se citam os autores de genealogias, dos quais o mais conhecido para nós é Hesíodo), devemos também acreditar neles quando dizem que os deuses podem ser convencidos com sacrifícios (365a-366a).

Nessas passagens é muito evidente o elemento formal que evidenciamos anteriormente: se a injustiça cometida pode ser reparada com ritos e fórmulas mágicas, é claro que será considerada como uma forma de contaminação, e não como uma ciente condição de consciência. Mas, ao mesmo tempo emerge outro problema que no Eutífron ficou em segundo plano, ou seja, o de estabelecer como deve ser corretamente pensada a natureza dos deuses. Das palavras de Gláucon e de Adimanto transparece uma imagem da divindade bastante redutiva: os deuses seriam tão ávidos pelas orações e pelos sacrifícios que recebem dos homens, ao ponto de fecharem um olho às suas culpas e criarem com esses homens maus um inescrupuloso comércio de favores recíprocos.

Tal motivação é depois articulada e enriquecida pela resposta de Sócrates. Os poetas (sobretudo Homero e Hesíodo) são acusados de ter imposto uma imagem errônea da divindade (377e). Sócrates cita antes de tudo o mesmo exemplo mencionado por $\mathrm{Eu}$ tífron, ou seja, as violências recíprocas que segundo Hesíodo teriam cometido Urano, seu filho Crono e o filho deste, Zeus. É claríssima, a alusão ao Eutífron, onde Sócrates desaprovava quem dizia ao jovem que 
não há nada de estranho em punir um pai culpado, dando como justificação que assim também se comportaram as maiores e mais antigas divindades (378b). Não é nem se deve dizer que os deuses cometem enganos e combatem entre si (378b-c), porque o deus é bom (379a) e não pode ser de todo responsável ou causador de nenhum mal, mas apenas e unicamente do bem (379c-380c). Por último, não cabe aos deuses mudar a própria natureza, nem assumir formas múltiplas, porque aquilo que é bom e perfeito só poderia mudar para pior; e também não têm razão os poetas quando contam que os deuses se transformam com o intuito de enganar os homens (381b sqq.).

Esses textos que citamos como exemplo permitemnos focalizar a estratégia geral que Platão utiliza para combater a cultura tradicional. 1. pelo método da refutação socrática ele demonstra que os expoentes desta cultura não possuem nenhum saber (Eutífron, não consegue responder corretamente à pergunta acerca da natureza do sagrado), mesmo excluindo quaisquer valorizações de mérito; 2 . quando analisa os conteúdos do saber tradicional, Platão observa que este é de qualidade bastante decadente, como demonstram as opinióes incorretas e superficiais que sacerdotes e poetas ("saber" de que os sacerdotes se serviam) possuem dos deuses (este exemplo não foi escolhido ao acaso, porque Platão, nas Leis, atribuirá uma importância ético-política decisiva, justamente a respeito das opiniões que os homens possuem acerca da divindade). 
(Página deixada propositadamente em branco) 


\title{
PLATÃO E A SOFÍSTICA
}

\author{
SÓCRATES ENTRE A CULTURA \\ TRADICIONAL E A SOFÍSTICA
}

\begin{abstract}
To período da formação filosófica de 1 Platão, a cultura tradicional não era mais o único paradigma intelectual e moral do homem grego. Tal cultura há tempos vinha sendo agredida por um modelo teórico/prático aparentemente alternativo, ou seja, pela chamada sofística. Não é possível descrever aqui os pormenores do confronto ocorrido em Atenas no limiar do século $\mathrm{V}$ entre a cultura tradicional e a sofística. Para entendermos o suficiente para nossos objetivos, vejamos um documento literário de grande interesse filosófico: a comédia As Nuvens de Aristófanes (representada em Atenas em 423).
\end{abstract}


Aristófanes é um típico representante da cultura tradicional, do conformismo social e da conservação dos valores vigentes, e age em um nível de elaboração teórica relativamente baixo. $\mathrm{Na}$ comédia, vemos um Sócrates meio filósofo e físico, meio sofista, ocupado em indagar questôes naturalistas de nenhuma relevância e, além disso, muito hábil em ensinar aos seus discípulos a arte do discurso e da persuasão para fins desonestos.

Com este Sócrates, Aristófanes tem a intenção de tornar mais robusto seu ódio pela filosofia, para ele, um saber moderno, na melhor das hipóteses inútil e com fim em si mesmo, e, na pior das hipóteses, até mesmo perigoso. É este "aspecto perigoso" da filosofia que mais nos interessa agora. Vemos na comédia um ancião camponês de nome Estrepsíades que tenta mandar seu filho de cabeça no ar, Fidípides, à escola de Sócrates, para ver se ele consegue aprender com verbosidade como distanciar seus credores. Ao final da comédia, Fidípides aprende tão bem as lições de argumentação de Sócrates, que se sente no direito de espancar seu pai. A moral da comédia não poderia ser mais óbvia: quando se seguem os ensinamentos dos filósofos, particularmente dos sofistas, acabamos pondo em discussão os tradicionais princípios éticos mais sagrados como a justiça (pagar aquilo que se deve) e a família.

Pareceu estranho a muitos críticos que, a figura central da comédia fosse o próprio Sócrates, ou seja, um homem que se ocupou pouco de pesquisas natura- 
listas (ou nunca se ocupou) e seguramente não poderia ser confundido com um sofista. Parece plausível que pelo menos uma parte do nosso estupor também fosse sentida por Platão. Ele percebeu que os atenienses não conseguiram encontrar um modo de enquadrar Sócrates nos mesmos moldes dos quais eles se serviam, por isso, após sucessivos erros, chegaram até mesmo a condená-lo à morte, como inimigo da sociedade.

Tudo isso se esclarece melhor se analisarmos as circunstâncias que prepararam a acusação e o processo. Sócrates foi acusado pelo regime democrático, o mesmo que havia colocado fim à experiência autoritária dos Trinta Tiranos. Sabendo-se que Sócrates no passado havia formulado mais de uma crítica contra o regime democrático, que havia demonstrado também alguma simpatia filoespartana (assim é, por exemplo, o Sócrates de Xenofonte), e que além do mais havia tido como amigos e discípulos homens de caráter tipicamente "tirânicos" como Alcibíades e Crítias, seria natural afirmar que a condenação de Sócrates veio por assim dizer, "de esquerda”. Mas essa hipótese é menos que certa. As principais acusações atribuídas a Sócrates (não acreditar nos deuses e corromper a juventude) são tipicamente "de direita", e representam boa parte das críticas que a cultura tradicional dirigia à sofística. Não é por acaso que na Apologia de Sócrates, o protagonista aponte entre os seus acusadores também o próprio Aristófanes.

Mas o que podemos concluir disso tudo? O que aconteceu com Sócrates convenceu Platão de que não 
se podia interpretar a vida política e cultural ateniense do século $\mathrm{V}$, como um simples duelo entre cultura tradicional e sofística. Se o único sujeito que se movia de verdade contra a corrente era Sócrates, isso significava que entre cultura tradicional e sofística, ambas criticadas por ele, existiam talvez convergências pouco visíveis, mas importantes e substanciais. Logo, aos olhos de Platão, identificar essas convergências passou a ser algo essencial, para poder focalizar o verdadeiro conflito cultural do seu tempo, ou seja, aquilo que dividia a mentalidade corrente da nova e revolucionária proposta socrática.

\section{GÓRGIAS E “DISCÍPULOS”}

Entre todos os sofistas que entraram em cena ateniense na segunda metade do século $\mathrm{V}$, sem dúvida, os dois mais importantes foram Górgias e Protágoras; não por acaso, Platão intitulou com esses dois nomes os dois diálogos mais complexos que escreveu na primeira fase da sua carreira. Todavia, o pensamento de Protágoras instigou a reflexão de Platão (em boa parte polêmica, mas não somente) muito mais do que o pensamento de Górgias.

De fato, no Górgias, Platão se confronta não propriamente com Górgias, mas sobretudo com aquelas personagens (representadas de modo exemplar por Cálicles) que usavam suas habilidades retórico-persuasivas para obter poder e prestígio pessoal, no interior 
de uma concepção ética imoralista e cínica, onde a única lei eficaz era a que convidava a satisfazer no mais alto grau os próprios desejos e vontades (ver cap. 2, pp. 25-6).

Esses sofistas (cuja figura histórica mais significativa é provavelmente a de Antifonte) representam para Platão uma ameaça perigosa, que ele tentará travar ao longo de todo o percurso de seu pensamento, particularmente n'A República. Mas, na realidade, essas duas posições não deixam muito espaço para o diálogo, nem para a possibilidade de convencimento recíproco. Em sua base, de fato, existem fundamentalmente duas opçóes opostas sobre a natureza da vida boa e sobre o que diz respeito aos objetivos que tornam o homem feliz; e, já que se trata precisamente de opções fundamentais, em grande medida não refletidas, não parece haver muito espaço para argumentaçóes. Com que meios podemos demonstrar - em matéria aparentemente subjetiva como, por exemplo, aquela que diz respeito à felicidade humana -, que existe somente um único modo pelo qual se pode conquistar esse objetivo? como convencer o homem injusto que declara ser feliz de que na verdade ele não é? Platão, como veremos, tentará fazê-lo. Como é lógico, essa sua tentativa será construída com a elaboração de um próprio complexo sistema de teorias, mais do que com o trabalho a partir do interior das teses de seus adversários, para as demolir dialeticamente (como faz, pelo contrário, com Protágoras).

Quanto a Górgias, a personagem que dá nome ao diálogo mostra, pelo menos aparentemente, que não 
partilha as posições imoralistas de seus admiradores Polo e Cálicles. Com efeito, Sócrates pode refutá-lo justamente porque Górgias abandona por um instante a defesa técnico-formal da retórica e admite ensinar também a justiça, dando assim a Sócrates o direito de exigir dele um saber conteudístico (460a). Mas essa concessão de Górgias não é consequente, pois, é muito provável que a personagem histórica Górgias tenha evitado esta armadilha. Ele, de fato, negava definir-se um mestre de virtude, e, de maneira mais geral, ele não admitia ser possível acessar a verdade e a realidade por meio do pensamento e da palavra. Parece que para o Górgias histórico, a arte da palavra realmente se reduzisse a um virtuosismo formal, e que consistisse inteiramente na sua força de sedução e de engano, sem outra finalidade que o próprio engano.

Essa organização dos argumentos mais coerente é refutada por Platão no Fedro, onde Sócrates observará sensatamente que quem engana, consegue enganar (isto é, fazer crer no falso) somente se possuir o conhecimento da verdade (262a): assim, é desmantelada a última tentativa do sofista de se esconder atrás do ponto de vista formal. Mas, no Górgias não existem pistas deste argumento. Rigorosamente falando, não podemos nem mesmo dizer que Górgias é refutado, ou que seja colocado em dúvida o universo moral no qual ele acreditava. Ele é aqui chamado a prestar contas somente como descobridor e promotor de uma técnica perigosa, que ignora os conteúdos e os valores éticos, além de particularmente adequada para favorecer e difundir concepçôes morais inconscienciosas. 
Diferente é o caso de Protágoras, outro grande sofista do século V. Ao sofista, Platão dedicou uma atenção muito maior, sobretudo porque ele se vangloriava abertamente de conseguir tornar os homens mais sábios e capazes, seja nos negócios privados, seja nos públicos. Este problema é tratado no Protágoras. No diálogo, o sofista declara de maneira explícita em que consiste a sua arte; é a "capacidade de tomar boas decisões em relação às questôes domésticas, para poder governar a própria casa do melhor modo possível, e em relação às questôes institucionais, para se tornar o mais eficiente gestor dos negócios do estado pela palavra e pela ação" (318e-319a). Em outras palavras, o que Protágoras ensina é a virtude política.

Mas, objeta Sócrates, a virtude política pode ser ensinada? Em primeiro lugar, nas açôes comuns, existe uma diferença entre disciplina técnica e política. De fato naquela técnica, seguimos sempre o parecer de um especialista, enquanto na política, escutamos conselhos de qualquer um. Por isso, pelo menos segundo comum opinião (que se reflete na práxis política ateniense), a virtude parece não poder ser ensinada. Até porque, o fato de os mais célebres políticos nunca terem conseguido se transformar em mestres, parece ir na mesma direção (319a-320c).

Protágoras usa o exemplo de um mito para defender a razão dessa comum opinião. Deste exemplo, o sofista consegue argumentar que, enquanto as com- 
petências técnicas foram distribuídas aos homens de modo que um único indivíduo pode ser útil a muitas pessoas não especializadas, a virtude política, por sua vez, foi doada a todos os homens por Zeus, sob a forma de pudor e justiça. A prova disto é o fato que todos os homens acreditam ser necessário dizer que são justos, mesmo que não sejam, mas seriam ridículos se afirmassem serem técnicos especialistas em algo que não são. Eis porque na política não se aceitam conselhos só de especialistas.

Estabelecido que a virtude é acessível a todos, Protágoras agora deve demonstrar que é possível ensinála. Se não fosse possível ensinar a virtude, os homens não puniriam os culpados, assim como não punem os defeitos que derivam da natureza. Enfim, vejamos o terceiro problema. Por que ninguém se preocupa em ensinar a virtude? Protágoras diz que não é verdade que ninguém ensina a virtude. Ao invés disso, é verdade que o ensinamento não tem a mesma eficácia em todas as pessoas. Mas o mesmo acontece com as técnicas. O filho de um grande flautista poderia se transformar em um excelente músico somente se possuísse os mesmos dotes naturais do pai; senão, por muito empenho que o pai coloque no ensinamento, ele permanecerá aquém do mestre. $\mathrm{O}$ mesmo se aplica para a virtude (política). Essa dificuldade não impede, todavia, que a virtude possa ser transmitida de geração em geração: a comunidade ensina as regras de convivência aos seus membros mais jovens, mais ou menos como lhes ensina a falar, e não é motivo de espanto que não 
seja possível determinar com precisão os professores (320c-328d).

A princípio, a réplica de Sócrates não parece ser pertinente. Sócrates quer que Protágoras admita que a virtude é uma coisa só, mas o sofista tenta excluir desta unidade pelo menos a coragem (ver 351b). Mas qual é o objetivo dessa tentativa? Para Platão, dizer que a virtude é uma só equivale substancialmente a dizer que é conhecimento. De fato, pode-se falar de uma virtude única somente se ela for o conhecimento do bem e do mal. Nesse caso, as diversas virtudes possuem apenas a função de especificar os âmbitos nos quais o bem e o mal se particularizam. No Protágoras, Sócrates se esforça por convencer o sofista a admitir que a virtude é uma só, para fazê-lo admitir que essa virtude é conhecimento.

Nesse contexto, explica-se também a parte final do diálogo, de difícil interpretação para muitos críticos. Aqui Sócrates demonstra que, se o homem considera também os possíveis êxitos futuros de suas açôes, o bom e o prazeroso terminam coincidindo: tanto a sofística quanto Sócrates ou Platão aceitavam, sem diferenças substanciais, o princípio de que todo homem age visando o próprio bem. Naturalmente, Platão tinha uma ideia do que era "prazeroso" muito diferente da dos sofistas e, além disso, (como veremos melhor mais adiante), para ele, não será um verdadeiro bem se o mesmo ocasionar um dano para os outros. Colocadas essas condições, a virtude ética (ou a ciência política), poderá ser reduzida ao cálculo dos bens e dos 
males, próximos e futuros, sem que disso resulte uma imagem mesquinha (353c-357e). Aquilo que Platão quer dizer é que qualquer ação feita visando um bem, qualquer que seja esse bem (inclusive o prazer), implica um ato cognitivo dirigido à identificação desse bem. Se alguém se convencer que seu ato cognitivo é correto, e considerando que ninguém deseja voluntariamente o mal e a dor (358a), tal ato cognitivo é já suficiente para representar a virtude, sem necessidade de qualquer outra intervenção.

Uma vez fixados esses pontos, ficam evidentes os defeitos da concepção de Protágoras. Ele declara que sabe ensinar a virtude. Ao invés de dizer que a virtude é um dom de Zeus aos homens, ele deveria admitir que se trata de uma ciência, como deseja Sócrates. Protágoras poderia se defender dizendo que o dom divino pode criar somente as condições de base necessárias para a aprendizagem, sobre as quais depois se poderia criar um verdadeiro saber. Mas também nesse caso ele deveria ter a capacidade de demonstrar a posse de uma ciência daquilo que é o bem capaz de causar aquelas melhorias que ele declara saber produzir.

Mas Protágoras, com base na exposição da sua visão do que é o homem, a educação e a virtude, não é capaz de satisfazer essas exigências. Para ele, o conhecimento daquilo que é o bem em parte deriva dos deuses e em parte é absorvida pelos homens, mais ou menos como se aprende a língua materna. De fato, a virtude que Protágoras ensina não tem muito a ver com o bem, por isso não é uma virtude verdadeira. A 
sua competência é muito similar àquela de Górgias, ou seja, consiste na arte de usar as palavras (312d). No final, também para Protágoras se confirma o juízo geral que Platão formula sobre a cultura do seu tempo: independentemente de terem pensado ou não, de terem defendido que esta investigação fosse possível ou não, ninguém havia tentado compreender seriamente o que é o bem e o mal para o homem.

\section{OS OBJETIVOS E OS LIMITES DA POLÊMICA CONTRA A CULTURA TRADICIONAL E A SOFÍSTICA}

Os casos de Górgias e de Protágoras são altamente emblemáticos para Platão. As duas personagens ambicionavam promover um uso audacioso e inovador da razão. Infelizmente, serviam-se desse meio sobretudo para mostrar o poder retórico da palavra, e não para analisar diretamente as normas e conteúdos da vida moral. O resultado é que, muitas vezes, terminavam simplesmente colocando esses novos instrumentos a serviço de qualquer um e para qualquer objetivo (esse é o caso de Protágoras).

Mas Platão sabia muito bem das inovações introduzidas pelos sofistas na arte de discutir e de argumentar. Nesse sentido, até Platão parece tomar partido da sofística contra a cultura tradicional (isto aparece concretamente pelo menos uma vez, mesmo que ironicamente, no Mênon 91b). Esta polêmica contra a 
sofística é bastante evidente no Eutidemo e no Fedro. No Eutidemo, as personagens principais são dois singulares sofistas: o próprio Eutidemo e seu irmão Dionisodoro. O leitor percebe logo que seu pseudo saber, não passa de uma estéril capacidade de contestar os adversários, muitas vezes por meio de truques lógicos e de jogo de palavras bastante medíocres. Parece que Platão, nesse caso, pretende simplesmente contraporse ao vazio verbalismo dos sofistas, que ao invés de visarem à seriedade moral dos ensinamentos socráticos, pretendem somente obter vitórias em discussões.

Mas não é tudo. Notemos em primeiro lugar que os dois sofistas, antes de darem início a suas exibiçóes, se declaram exatamente como Protágoras, mestres de virtude (273d). Não devemos subestimar o fato que Sócrates afirma mais de uma vez que gostaria de entrar para a escola deles, recusando terminantemente a crítica de uma personagem anônima que lhe dizia para não perder tempo com gente assim (305b-306d). Essa personagem anônima é facilmente reconhecível, é Isócrates, reitor e mestre de humanidade, contemporâneo de Platão e fundador de uma escola em Atenas, concorrente da Academia. As polêmicas entre as duas escolas devem ter sido bastante acesas, alimentadas entre outras coisas pelo fato de que Isócrates nomeava o seu saber com o mesmo termo platônico "filosofia", e, além disso, os dois institutos tinham a ambição de possuir a primazia na educação moral e cívica.

Isócrates pode ser considerado um expoente da melhor parte da cultura tradicional (ver Fedro 278e279a), mas, mesmo diferenciando-se da obtusa arro- 
gância de muitos de seus expoentes, era violentamente hostil aos sofistas. Na sua oração Contra os sofistas, Isócrates expõe sua própria concepção humanística da "filosofia", traduzida como um discurso educativo que funda suas raízes na verdade e na justiça, diametralmente oposta à universal técnica refutatória, usada pela sofística que era indiferente à verdade ou falsidade da tese em discussão. Platão certamente concordava com esse ponto. Mas nem por isso ele dava total razão a Isócrates. Platão sustentava que o método refutatório de perguntas e respostas breves, usado por pelo menos uma parte da sofística e também pelo próprio Sócrates, tivesse introduzido na cultura do seu tempo um elemento novo e de grande valor, e que era essa a estrada justa para obter a verdade, bem superior ao tradicional modo de produzir textos e discursos empregado por Isócrates, literariamente elegante e talvez aparentemente persuasivo, mas nem um pouco sólido do ponto de vista científico.

A operação que Platão está tentando realizar é muito delicada: recomendar o correto uso do logos, conservando o que os métodos sofísticos tinham de bom, e manter sua crítica contra a sofística rigorosamente distinta das polêmicas fáceis que a cultura tradicional conduzia contra ela. Não parecerá pois tão estranho constatar que Platão, por um lado, se mostre mais próximo dos conservadores quando denuncia o subjetivismo corrosivo dos sofistas, mas por outro, próximo dos sofistas, quando promove o uso da dialética de modo incisivo e audacioso. Por outro lado, esta 
dupla atitude era já detectável na figura de Sócrates, e é justamente por essa sua natureza refractária em se inserir nos esquemas comuns que a maioria dos seus contemporâneos não o conseguiu entender.

\section{PLATÃO CONTRA O RELATIVISMO PROTAGÓRICO}

Mencionar o subjetivismo torna necessário considerar outro aspecto da polêmica de Platão contra os sofistas (particularmente, Protágoras), que é determinante para podermos entender a origem das teses fundamentais do pensamento platônico. $\mathrm{Na}$ primeira parte do percurso filosófico de Platão vimos que tudo converge em direção à necessidade de especificar os verdadeiros fundamentos da vida boa. Essa necessidade baseia-se, por sua vez, sobre o pressuposto de que existem normas ou valores universais válidos para todos, que devemos antes de tudo conhecer, e só se nos orientarmos por eles, conseguiremos o resultado esperado. Se Platão tem razão, devem existir realmente os "universais" e, deve existir também um método eficiente que nos faça conhecê-los de forma minimamente suficiente para podermos governar a vida prática, seja do ponto de vista do indivíduo (ética), seja do ponto de vista do estado (política).

Mas o desafio mais perigoso a propósito desta posição platônica vem exatamente de Protágoras: ele, com a sua célebre tese de que o homem é a medida de todas 
as coisas, parece promover o mais ferrenho subjetivismo e relativismo, tanto no plano teórico quanto no prático. Para Platão, refutar Protágoras é, portanto, ao mesmo tempo, necessário e útil, porque é graças à demonstração de que a tese do sofista é insustentável e contraditória, que ele conseguirá produzir as motivações para poder promover e justificar a sua própria visão das coisas.

É na primeira parte do Teeteto que Platão expõe suas argumentaçôes a respeito desse tema. $\mathrm{O}$ diálogo iniciase a partir de uma típica questão socrática, colocada na forma de "o que é": neste caso trata-se do conhecimento. Depois de duas breves sessões sobre a ciência matemática e sobre a arte maiêutica de Sócrates, o jovem Teeteto, chamado em causa, formula uma primeira hipótese de solução: o conhecimento é sensação.

Sócrates observa que a sua definição equivale, substancialmente, à máxima protagórica, segundo a qual o homem é a medida de todas as coisas (151e). O equilíbrio entre as duas definições é a noção de "aparecer”. Protágoras, de fato, pretende dizer que cada coisa é para alguém tal como lhe parece ser; e este "parecer" não significa nada mais que "ter uma sensação". Por exemplo, não podemos definir o vento como frio ou quente em si, esse juízo existe somente como consequência de uma sensação física que é diferente de sujeito para sujeito. Por isso, é correto afirmar que o homem é a medida daquilo que experimenta, dado que o indivíduo avalia de um modo indiscutível sua própria e singular sensação. 
O relativismo protagórico é, portanto, fruto de uma concepção sensitiva do conhecimento. Mas, para Sócrates, esta concepção é considerada como consequência necessária de uma teoria geral sobre a realidade, ou seja, é uma visão do movimento universal de Heráclito. Tal visão é atribuída não somente a Heráclito, mas a toda tradição mítica e pré-socrática (à exceção de Parmênides), e consiste na hipótese de que na realidade sensível, tudo se move e se transforma constantemente. A consequência disto é que, nesse estado de coisas, nada existe como unidade autônoma e independente (153e), assim, nem mesmo o conhecimento pode ser considerado um fato estável e unívoco.

Colocado o pressuposto que o conhecimento é sensação, que a sensação é um encontro entre sujeito sensível e objeto sentido e que estes se modificam constantemente, é claro que cada sensação será diferente de outra também para o mesmo sujeito e em momentos diferentes. Assim, desaparece a possibilidade de unir de maneira estável um sujeito a um predicado. Não poderemos, portanto, dizer que A é B, como se A fosse B de maneira estável para todos os casos, mas, sim, que $\mathrm{A}$ nesse momento me parece $\mathrm{B}$, ou seja, indicando como me parece aqui e agora, dado que poderá parecer de maneira diversa para mim ou para outros, em outro lugar e momento. $\mathrm{O}$ resultado dessa posição, aparentemente paradoxal, é que seremos legitimados a afirmar que todas as opiniōes são verdadeiras, mesmo havendo contrastes entre elas.

Vimos que, no Protágoras, o sofista se declara mestre de virtudes, isto é, capaz de ensinar como conduzir 
de um modo feliz a casa e o estado, mas na prática, o único saber de que dispunha era o de ser capaz de persuadir (e de ensinar esta prática a seus discípulos). Agora, podemos ver que esta redução do saber a persuasão depende diretamente da tese do "homem medida". A retórica se transforma na principal forma de saber, precisamente porque as coisas não são assim como são, mas são como nos parecem ser. Se existisse algo conhecível além da aparência, existiria também um saber superior à retórica; mas, a partir do momento que realmente não existe, a retórica, que é precisamente a arte de fazer "aparecer" as coisas em um determinado modo mais que em outro, passa a ser a forma de saber mais elevada.

Sócrates rebate essa doutrina "protagórica" com duas objeções: em primeiro lugar, se o conhecimento fosse sensação, todos os homens deveriam ser igualmente sábios, e os homens não seriam mais sábios do que os animais, porque os animais também possuem sensações; em segundo, ter-se-ia conhecimento apenas quando existisse uma sensação presente, e a recordação não seria um conhecimento (161b-164c). Que essas objeções não sejam determinantes, é admitido também pacificamente por Sócrates, o qual assume para si a responsabilidade de reforçar ao máximo a posição de Protágoras, intencionalmente pronunciando um discurso em sua defesa, assim como teria feito o sofista: é a chamada Apologia de Protágoras (166a-168c).

Dizendo que a sensação é sempre verdadeira, Protágoras quer dizer que ninguém pode duvidar da verdade daquilo que alguém pode sentir e provar. To- 
davia, com esta tese, ele não pretende negar que existam coisas boas e más, úteis e inúteis; além do mais, a habilidade do sábio é exatamente a capacidade de fazer passar por boas as coisas que parecem más. Mas isto não significa enganar as pessoas convencendo-as a escolher o mal. Pelo contrário, significa instruir as pessoas que erram, e que confundem as coisas boas pensando serem ruins, a compreenderem que tais coisas são efetivamente boas; a tarefa do bom orador e do bom sofista consiste em fazer com que a cidade entenda que a justiça é o bem e não o mal. Com este discurso realiza-se o paradoxo de que existem homens mais sábios que outros, mesmo que não existam opiniōes erradas (167d).

A tese de Protágoras se sustenta no pressuposto que a verdade e o saber possam existir separadamente do bem e do útil. Se não é possível convencer alguém que tenha uma opinião falsa a mudar para uma verdadeira, mas é possível conduzi-lo a uma melhor e mais útil, e isto significa que o bem não é uma coisa que se possa conhecer. Se de fato pudéssemos conhecer o bem, tal conhecimento seria uma sensação, e assim sendo, todas as opiniōes do que é o bem seriam igualmente válidas. Nessas condiçôes, não existiria mais a possibilidade de distinguirmos aquilo que é mais ou menos bom ou útil, e, consequentemente, também deixaria de existir a possibilidade concreta de modificar as atitudes dos homens em relação a isso. Assim, Platão pode refutar Protágoras somente se, de alguma forma, conseguir provar que distinguir o verdadeiro do falso em geral é necessário para distinguir o que é útil (ou bom) daquilo que não é. 


\section{OS DEFEITOS DA POSIÇÃO DE PROTÁGORAS}

Para poder demonstrar esta tese, Platão constata que a maioria dos homens, praticamente todos exceto Protágoras, não acredita de fato que todas as opinióes sejam verdadeiras. Pelo contrário, como bem se vê facilmente em caso de graves perigos como guerras, doenças ou tempestades marítimas, as pessoas confiam sem titubeaçóes na sabedoria dos especialistas, mostrando, assim, que "toda a humanidade [...] está cheia de pessoas que, ou para si mesmas, ou para outros seres vivos, ou pelas obras que realizam, procuram quem as instrua e oriente" (170b; ver também Eutidemo 279e-280a). Aquilo que Platão pretende provar é que, também no que diz respeito ao útil, todos compartilham a opinião de que distinguir o verdadeiro do falso é efetivamente relevante: "quando uma cidade, ao estabelecer suas leis, distingue aquelas que considera adequadas para si, mais uma vez Protágoras deve admitir que nessa distinção existe sobretudo uma diferença entre conselheiros e conselheiros, entre cidades e cidades, acerca de suas opiniōes a respeito da verdade; e não ousará afirmar que aquelas leis que uma cidade estabelece para si mesma pensando serem úteis, necessariamente serão úteis sempre" (172a-b).

A unanimidade desses comportamentos implica evidentemente a persuasão universal de que exista algo como "uma saúde" em geral, e que existam conhecimentos precisos capazes de encontrá-la; que exista algo como "a justiça”, e que justamente por isso se 
possam fixar normas (como por exemplo, não matar) válidas para todos e para todas as épocas.

Segundo Platão, essas observações são já suficientes para pôr em crise o ponto de vista de Protágoras. Para quem sustentar que o único critério de verdade é a opinião, a ponto de dizer que todas as opiniôes são verdadeiras, não pode senão criar algum embaraço o fato de que a grande maioria das opiniōes (todas, pode-se dizer, menos a sua) acredita que exista uma diferença real entre verdadeiro e falso, e que tal diferença possa ser também aplicada ao que é útil e danoso. Em outras palavras, a ideia de Protágoras de que o útil se salva da dicotomia verdadeiro/falso contrasta com a opinião comum das pessoas, e dificilmente Protágoras poderá ignorar esse fato, justamente porque a seu ver, a verdade coincide com a opiniāo; logo, será difícil negar que as opiniōes mais difusas tenham maiores probabilidades de serem válidas do que aquelas sustentadas por poucos, ou, na pior das hipóteses, por apenas uma pessoa (como no seu caso).

O confronto com a filosofia de Protágoras revelase, assim, muito interessante e frutífero para Platão. Refutando a posição protagórica, ele demonstra que, fugindo da pergunta sobre o que é verdadeiro e o que é falso em geral, não é possível compreender e justificar o modo pelo qual os homens efetivamente pensam e agem. De fato, os comportamentos e as opinióes humanas pressupõem convicções gerais no que diz respeito ao verdadeiro e ao falso e os conceitos universais aos quais eles se referem, indispensáveis para 
fazer com que tais comportamentos e opinióes sejam aquilo que empiricamente são. Por isso, é claro que a posição protagórica não é simplesmente agredida por Platão do exterior, mediante uma mera contraposição entre verdade e opinião, entre universal e particular, entre móvel e imóvel. Pelo contrário, Platão acredita tê-la esgotado a partir de seu interior, mostrando que o mesmo ponto de vista empírico (ou seja, o ponto de vista da opinião) pressupóe e implica a existência da verdade além da opinião, do universal além do individual e do imóvel além do móvel. 
(Página deixada propositadamente em branco) 


\author{
CAPÍTULO V \\ A CONCEPÇÃO PLATÔNICA DA \\ REALIDADE E DO CONHECIMENTO
}

\author{
CONTRA O RELATIVISMO E O \\ MATERIALISMO DOMINANTES
}

\begin{abstract}
$\triangle$ relação que vimos instituída no Teeteto A entre o relativismo e o subjetivismo cognitivo e a concepção mobilista da realidade implica, para Platão, que o problema do conhecimento não pode ser enfrentado somente dentro da esfera do pensamento e do discurso, mas deve também envolver o objeto ao qual o discurso se refere. $\mathrm{O}$ grau de estabilidade e de certeza de um conhecimento não depende apenas dos critérios interiores à própria consciência, mas da natureza dos objetos aos quais esse conhecimento se dirige. Esse pressuposto estimula a pesquisa de Platão em direção às especulações sobre a natureza das coisas, como haviam feito os pré-socráticos, fazendo-o se distanciar, pelo menos parcialmente, das linhas do pensamento
\end{abstract}


socrático. Os pré-socráticos, de fato, questionavam se a realidade (ou natureza) era móvel ou imóvel, una ou múltipla, etc. É evidente que para solucionar tal problema tornava-se fundamental determinar a natureza do conhecimento.

Em linhas gerais, a tese de Platão é que no fundo de todos os erros teóricos e práticos existe uma concepção incorreta da realidade, ou seja, aquela heraclítica, por sua vez ligada (segundo Platão) ao subjetivismo e ao relativismo protagórico. Vimos no capítulo anterior que os comportamentos geralmente adotados por todos pressupõem de modo implícito a existência de critérios universais de avaliação (ou melhor, de princípios que são intrinsecamente verdadeiros de um ponto de vista geral). Isso, porém, não quer dizer que estes comportamentos fossem acompanhados por uma consciência teórica dos mesmos. Pelo contrário, a maior parte das pessoas acredita que existam, sim, coisas boas e justas, mas não quer ouvir falar de um bem ou um justo em si, indiferentes ao tempo e às prespectivas (ver A República 478e-479a); e assim, essas pessoas demonstram aceitar implicitamente o ponto de vista de Heráclito, segundo o qual tudo é particular, transitório e mutável. Portanto, o objetivo de Platão será demonstrar que a concepção heraclítica é errada e contraditória. 


\section{LINGUAGEM, SENSAÇÃO E PENSAMENTO}

As críticas de Platão ao heraclitismo são expostas no Teeteto e na parte final do Crátilo. Nesse último, o problema central é a natureza dos nomes que damos às coisas, se devem ser considerados convencionais (como sustenta Hermógenes), ou naturais (como acredita Crátilo). Através da refutação de ambas as teses, emergirá aquela que para Platão é a solução correta.

$\mathrm{O}$ recurso aos nomes (em geral, à linguagem) está interligado a uma doutrina convencional do saber que, por sua vez, possui uma relação precisa com as doutrinas de Heráclito. Se tudo flui constantemente, se, como acreditava o Efésio, não é possível se banhar duas vezes no mesmo rio (ou como sustentava Crátilo, nem mesmo uma vez), porque o rio muda sempre, como será possível manter a realidade imóvel pelo menos o suficiente para conseguirmos cumprir os propósitos da vida prática? Será possível, argumenta o nominalista, se, ao menos de maneira convencional, decidirmos usar os mesmos nomes: as mudanças que ocorrem na realidade são bastante lentas, de fato, razão pela qual não podemos chamar um objeto com o mesmo nome por muito tempo. De tal maneira, a concepção heraclítica da realidade se esquiva dos maiores paradoxos e consegue permanecer de pé.

Mas, para Platão, trata-se de uma solução ineficaz. A linguagem é criada apenas depois que o processo cognitivo já foi concluído e tem justamente a função 
de fixar de maneira estável os aspectos da realidade que conhecemos como invariáveis (mesmo relativamente). Mas, se a única realidade à qual o conhecimento pode se dirigir é a materialidade móvel das coisas, não existe nada que possa ser nomeado pela primeira vez, porque não há nada de invariável. Tal não pode ser o nome, sob pena de se cair em um evidente círculo vicioso: "que conhecimento [...] podemos dizer que eles tinham quando eram legisladores e puseram nomes às coisas, se naquela altura, nenhum nome ainda não tinha sido dado a nada e só podemos conhecer as coisas através dos nomes?" (438b).

Os homens dão nomes às coisas na intenção de fixá-las em uma forma linguística estável, para assim poderem uniformizar o modo de pensar e de conhecer as coisas: o branco, o belo e todas outras coisas deste gênero serão brancas ou belas e assim permanecem, de modo que o pensamento possa considerá-las idênticas e a linguagem possa designá-las por meio da mesma palavra. Os erros linguísticos são, portanto, generalizações falidas em busca da invariabilidade que procurava ser nomeada. Por isso, através das palavras e dos nomes, que constituem o último ato do conhecimento, não podemos aprender nada (440c).

\section{O SUJEITO (A ALMA)}

Se os raciocínios conduzidos até aqui são corretos, pelo contrário, nasce a necessidade de postular um ob- 
jeto de conhecimento dotado de características bem precisas que consistem na estabilidade e invariabilidade no tempo. Mas há mais. Na concepção heraclítica da realidade, nada permanece imóvel, nem o objeto que se conhece, nem o sujeito conhecedor. No Crátilo, Sócrates observa que, se tudo muda, muda também o conhecimento, resultando que o conhecimento no final será não conhecimento, ou seja, não haverá mais conhecimento. A consequência dessa tese é que "não existira mais nem um sujeito conhecedor nem o objeto a ser conhecido". E vice-versa, "se aquele que conhece existe sempre, e existe também o objeto conhecido, e existem o belo e o bom e cada um destes entes, é evidente que estes entes de que agora estamos falando não são similares nem ao fluxo nem ao movimento" (440b).

A necessidade de que exista um conhecimento que deriva do dado empírico irrefutável, razão pela qual há uma diferença entre conhecimento e ignorância - não só conduz à refutação do mobilismo heraclítico e postula a existência de uma realidade invariável, mas implica, além disso, o desdobramento do fenômeno cognitivo entre sujeito e objeto. Segundo a discussão conduzida no Crátilo, não é suficiente atribuir ao sujeito somente os nomes ou, em geral, a linguagem, porque deverá existir, antes do nascimento da linguagem, alguém que imponha nomes às coisas, ou seja, um sujeito que realiza essa operação tendo por base o seu conhecimento acerca do objeto.

Esse discurso se realiza de modo mais amplo no Teeteto (184a sqq.). Pondo por hipótese que conheci- 
mento é sensação, é razoável afirmar que observamos as cores por meio dos olhos e que ouvimos os sons por meio dos ouvidos. Mas isso não significa, porém, que a percepção interesse somente aos nossos órgãos sensitivos. Tais órgãos são o instrumento pelo qual o sujeito ou princípio percebe as sensações. Isso fica claro se consideramos a cooperação que se dá entre os vários sentidos. Podemos pensar unitariamente em dois objetos que percebemos um por meio da visão e outro por meio da audição, e tal pensamento não poderá ser somente uma sensação visual ou auditiva, nem uma sensação mista entre esses dois sentidos; deve evidentemente ser algo de diferente, isto é, uma forma de conhecimento diferente da sensação (ou seja, o pensamento).

Todavia é certo que, se existe o pensamento, deve também existir um sujeito pensante, tipologicamente afim ao seu próprio objeto e capaz de manter uma identidade contínua com si mesmo, não obstante as variações de suas experiências cognitivas. Esse sujeito é a alma, que é capaz de discernir certas coisas "por si mediante si mesma, e outras mediante a faculdade do corpo" (185e).

Como dizíamos, a alma é geralmente responsável pelo conhecimento sensível, mas é também sujeito responsável pelo próprio conhecimento desses tipos: o primeiro é o conhecimento do particular e o segundo é o conhecimento do universal. A respeito dos objetos desse segundo tipo de conhecimentos, são eloquentes os exemplos utilizados por Platão: ser, similar, dissimilar, outro, idêntico, belo, feio, bom, mau. Mas o 
mesmo discurso vale também para objetos como a moleza e a dureza, porque se é verdade que a alma que as perceciona por meio das sensações, em relação ao "seu ser e em relação ao que são essas duas características, à sua oposição recíproca e não só, a existência desta oposição, todas estas são coisas que a alma procura por si mesma esclarecer-nos, reexaminando uma após a outra e comparando-as entre si” (186b).

É claro, então, que ao conhecimento sensível e natural, comum aos homens e aos animais desde o nascimento, se agregará ao longo do tempo uma reflexão que é própria da alma, a qual, partindo das sensaçôes, adquire diferentes conhecimentos (isto é, não sensíveis) "relativamente ao seu ser [scil. ao das sensaçôes] e à sua utilidade" (186c). Se atingir o ser é responsabilidade da alma, e considerando que, no pensamento e na linguagem dos Gregos, ser e verdade de certa forma se correspondem, só o conhecimento da alma é conhecimento da verdade das coisas: não haverá conhecimento dos sentidos nas afeções, mas "no raciocínio que se faz em torno delas: porque por essa via é possível, como parece, tocar o ser e a verdade, pela outra via, é impossível" (186d).

\section{AS VERDADEIRAS CAUSAS DO DEVIR}

A análise do modo de conhecer humano conduziu nossa investigação a postular a existência de um sujeito e de um objeto estáveis, e permitiu-nos tam- 
bém tecer algumas considerações preliminares sobre a natureza de tais objetos: se a realidade natural possui as características da mobilidade heraclítica, pode-se presumir que os objetos do conhecimento devem ser procurados em outro lugar. Mas se em vez de partir do ponto de vista gnoseológico (a análise do conhecimento), partirmos diretamente do ponto de vista ontológico (a análise da realidade como tal), chegaremos à mesma conclusão.

Vejamos como Platão ataca esse tema no Fédon. Nesse diálogo, ele conta (à sua maneira) o último dia de Sócrates no cárcere, dando particular ênfase às discussões que seu mestre teria tido ali com dois tebanos, Símias e Cebes. O tema central dessa obra é a demonstração da imortalidade da alma. A última parte é a que mais nos interessa, ou seja, quando Sócrates, estimulado por uma objeção de Cebes, expõe o seu último e mais importante argumento.

Devido à seriedade do problema, afirma Sócrates, antes de mais é necessário buscar as causas da geração e da corrupção das coisas. Sócrates conta que quando era jovem, se apaixonara pelos questionamentos em torno das causas e que, por isso, se interessara pelas doutrinas dos pré-socráticos. Tais doutrinas colocavam como causas primeiras da realidade os elementos físicos, tais como o ar, a água, o fogo, etc., o que implicava que para cada um desses fenômenos se poderia ter uma explicação em termos físico-materiais. Por exemplo, diz Sócrates, eu pensava "ter uma ideia certa e satisfatória quando, ao colocar um homem alto ao lado de um baixo, este me parecia mais alto somente 
por causa da sua cabeça" e "me parecia que dez era maior que oito pelo dois que tem a mais" (96d-e). Nesses casos, seriam a cabeça e o dois, respectivamente, o motivo de um homem ser maior que o outro e de um número ser maior que outro.

Mas logo Sócrates se apercebeu de que esse tipo de explicação levantava contradições dificilmente solucionáveis. Se tomarmos um objeto $\mathrm{A}$, que é um, e a ele lhe acrescentarmos um objeto $B$, que é também um, a soma destes dois objetos será dois. Mas este "dois", antes da soma, não pertencia nem ao objeto A nem ao B. Então como é possível que a simples junção mecânica de dois objetos faça aparecer alguma coisa que antes não existia? O "dois" parece ter surgido do nada (96e-97a).

Esse problema que colocamos ocupara grande parte das especulaçôes pré-socráticas. Parmênides foi o primeiro a declarar a impossibilidade de um "não" ser e a denunciar consequentemente a dificuldade de conceber e explicar o devir das coisas. O que será de fato o devir, a mutação, senão a passagem de algo que é a algo que não é, ou seja, do ser ao nada, e vice-versa? Da simples soma que serve de exemplo a Platão, parece que se verificam estranhos fenômenos: aquilo que antes existia agora não existe mais (não temos mais "um" objeto, mas "dois"), e apareceu do nada algo que não existia antes (o dois). Parece impossível explicar o devir de maneira lógica e racional.

Alguns filósofos posteriores a Parmênides (Anaxágoras, Empédocles e os atomistas Leucipo e Demócrito) haviam tentado rebater essa dificuldade afirman- 
do que o devir não equivale ao nascimento e à morte absoluta de alguma coisa, mas à diversa agregação ou desagregação dos mesmos elementos; desse modo, não há nada que seja verdadeiramente criado ou destruído. Mas, essa explicação não satisfaz plenamente Platão. Mesmo que depois da união de A e B, o novo objeto seja sempre a soma dos dois elementos que existiam antes, a configuração que se criou é nova: agora temos um "dois" que antes não existia. Esse "dois" parece, portanto, ter nascido do nada. Mas, para explicar esse fenômeno, nenhuma das causas materiais apontadas pelos pré-socráticos é realmente suficiente.

A análise das causas da realidade conduz, assim, à postulação da existência de objetos invariáveis, similares àqueles que se mostraram necessários postular para o fundamento do conhecimento. Esses objetos devem ser imateriais. Explica Sócrates, no mesmo diálogo, que uma coisa é bela por causa do belo, e não "porque tem uma cor brilhante ou tem uma certa figura, ou por causa de outras propriedades desse tipo" (100d): de fato, essas são todas qualidades materiais e sensíveis que não saberiam explicar o nascimento e a presença de "algo" como a beleza. O mesmo vale para todas as coisas: a causa de algo ser grande é a grandeza; de ser pequeno, a pequenez; do dois, a dualidade (101a sqq.), etc. Trata-se, evidentemente, de qualidades das quais, de alguma forma, o objeto participa e que não devem ser absolutamente reduzidas a elementos ou a dinâmicas materiais que o compóem ou o produzem. 
No Fédon, além da breve análise da filosofia présocrática, é mencionado também outro problema, ou seja, o das chamadas causas finais. Insatisfeito com as explicaçôes dos naturalistas, Sócrates conta que começou a se interessar pela filosofia de Anaxágoras, porque ele defendia que existia uma "mente" (ou intelecto) que era "causa e ordenadora de todas as coisas". $\mathrm{Na}$ expectativa de Sócrates, esse intelecto representaria a introdução de uma causa capaz de ordenar e dispor "todas as coisas juntas, ou individualmente, da melhor forma", logo "quem quisesse encontrar a causa de todas as coisas, ou seja, a forma como cada coisa se gera, se corrompe e é, devia antes de tudo tentar encontrar o melhor modo de ser" (97c). Certo desse princípio, Anaxágoras deveria ser capaz não somente de ensinar "se a terra é plana ou redonda", mas também explicar "porque deve ser assim e não pode ser de outro modo, servindo-se do conceito de melhor, isto é, que para a terra é melhor ser assim ou de outra forma" (97d-e).

Infelizmente, as esperanças de Sócrates foram frustradas porque, no seu livro, Anaxágoras não fazia verdadeiramente nenhum uso da mente e apresentava como principais causas os conhecidos elementos naturais como o ar, o éter, a água, etc. (98c). Seria como, diz Sócrates, explicar o fato de estar no cárcere dizendo que tem ossos e nervos dispostos de um certo modo, ao invés de explicar que está ali porque "pareceu bem" aos atenienses condená-lo, e porque a 
ele também "pareceu bem" permanecer na prisão, ao invés de fugir ou se exilar (97d-e). Explica Sócrates que os elementos materiais do seu corpo, são sem dúvida necessários para que possa agir; "mas afirmar que eles são as causas pelas quais faço o que faço, e dizer ao mesmo tempo que penso sem que isso implique uma escolha do melhor da minha parte, na verdade, este é o modo mais grosseiro e insensato de se exprimir" (98c-99b).

Assim sendo, as causas materiais expostas pelos filósofos naturalistas revelam-se duplamente insuficientes. Como vimos, não somente são ineficazes, porque não esclarecem o surgimento ou desaparecimento de formas particulares (por exemplo, a forma do dois ou do grande); além disso, não dizem nada a respeito da finalidade dos processos pelos quais deveriam ser responsáveis: para fazer isto, de fato, ocorre também mostrar o dever ser de cada coisa segundo aquilo que é melhor.

Platão inaugura, com isso, um importante paradigma teórico, um modo bem definido de entendimento da realidade das coisas e da natureza do conhecimento, com os quais as especulaçôes seguintes se deverão confrontar muitas vezes. Para compreender a realidade, Platão não se satisfaz somente em saber como se desenvolvem os fatos, mas quer saber também porquê os fatos acontecem de uma maneira e não de outra; isto é, ele busca um motivo de ordem finalista, sem o qual não se pode dizer que a investigação das causas esteja completa. 
Poderíamos nos perguntar se, para realizar essa exigência, seria possível usar a mesma explicação proposta no Fédon para o aparecimento e desaparecimento das formas. Por outras palavras, dizer que uma coisa é grande por causa da grandeza, é suficiente para explicar também porquê é melhor que essa coisa seja grande e não pequena? Ou melhor, de maneira mais geral: os conceitos universais introduzidos por Platão como causas no final do Fédon são também causas finais (e não apenas, para usar a terminologia criada por Aristóteles, causas formais)? Mesmo que estudiosos se tenham esforçado por demonstrar que sim, na realidade, a resposta deve ser não. No Fédon, de fato, Platão coloca o problema, quer das causas formais, quer das causas finais, mas resolve realmente apenas o primeiro. Para encontrarmos uma verdadeira resposta à questão das causas finais, vamos ter que esperar (mais adiante) o Filebo e o Timeu. 
(Página deixada propositadamente em branco) 


\author{
CAPÍTULO VI \\ A DESCOBERTA DA \\ DIMENSÃO IDEAL E AS \\ CARACTERÍSTICAS DA \\ METAFÍSICA PLATÔNICA
}

A PERGUNTA SOCRÁTICA

\begin{abstract}
A Ristóteles escreveu que Sócrates se ocuApara apenas de questóes éticas, no âmbito das quais buscava identificar o universal, ou seja, a definição (Metafísica I, 987b). Por meio dos ensinamentos de Sócrates, Platão não só orientou suas próprias pesquisas sobre a ética, mas tomou conhecimento de um novo método de investigação, que ia direto ao cerne dos problemas, ou seja, à essência das coisas procuradas. É esse o método construído a partir do questionamento socrático que, em sua formulação mais simples, se exprime na forma da pergunta "o que é?"

Nos diálogos temos diversos exemplos desse procedimento socrático. No Cármides é colocada a pergunta sobre o que é a sabedoria ou a temperança (sophrosyne: o
\end{abstract}


vocábulo grego oscila entre esses dois significados); no Eutífron, o que é o sagrado (ou santo); no Laques, a coragem; no Hipias Maior, a beleza; no primeiro livro d'A República, a justiça; no Mênon, a virtude; no Teeteto, o conhecimento. Essas perguntas são feitas por Sócrates a um ou mais interlocutores, mas as respostas acabam sempre por ser refutadas, de modo que nesses diálogos (incluindo o primeiro livro d'A República, se separado dos outros nove) a indagação não é bem sucedida.

Diante de uma pergunta relativa a um conceito, os interlocutores de Sócrates pensam, de fato, poder escapar dela com alguns exemplos significativos, ou com uma definição que apreende apenas uma parte do objeto procurado. Assim, não é muito difícil para Sócrates colocá-los em contradição. Por exemplo, no Hipias Maior, Sócrates demonstra que a beleza não pode ser nem uma linda mulher e nem o ouro (como propunha Hípias), porque existem outras coisas belas de gêneros completamente diferentes (288b-289d); n'A República, a justiça não pode consistir simplesmente na restituição de débitos, porque não seria nada correto devolver as armas emprestadas de alguém que entretanto enlouqueceu (331c-e).

A dificuldade com a qual se chocam os interlocutores de Sócrates não se deve apenas à falta de hábito com certo tipo de indagação, e nem mesmo à desencorajadora superficialidade que demonstram nas suas respostas. A dificuldade consiste no fato de a pergunta socrática se dirigir para o universal, e no fato de ser realmente muito difícil encontrar um universal que 
possa ser aplicado sem exceções a todos os casos. Se eu pergunto o que é certa qualidade $x$, a resposta não poderá limitar-se a indicar uma coisa em que $x$ esteja presente (por exemplo, a mulher "bela"), mas deverá compreender de modo preciso e circunscrito precisamente aquela qualidade $x$, cuja presença em uma determinada série de objetos faz com que qualquer um deles possa ser chamado $x$. No caso do Hipias Maior (287d), a pergunta formulada por Sócrates não quer saber "o que é belo" ( $t i$ kalón) (isto é, conhecer casos de coisas belas), mas "o que é o belo" (to kalón), onde é evidente a função discriminante do artigo definido unido ao adjetivo neutro: ti kalón significa em grego "algo belo", enquanto to kalón significa "o belo", isto é, "a beleza”. É claro que desse modo surge não somente o problema de estabelecer a relação entre particular e universal, mas também entre unidade e multiplicidade. A beleza está para as coisas belas como o universal está para o particular e como o uno está para a multiplicidade.

Que os diálogos que perguntam pela definição terminem de modo aporético não é, na realidade, nem um caso nem mera estratégia retórica; nem sequer é casual que em nenhum ponto dos escritos platônicos se encontrem aquelas definições de conceitos universais inutilmente procuradas nos diálogos da juventude. É igualmente incorreta a imagem tradicional que vê em Sócrates o filósofo que faz perguntas e em Platão o filósofo que encontra e formula respostas. $\mathrm{O}$ dado real do qual se deve partir é que o indagar socrá- 
tico reclama a existência de um objeto universal do qual parece ser impossível dar conta completamente.

\section{DA PERGUNTA SOCRÁTICA À "TEORIA DAS IDEIAS"}

No entanto, não obstante as dificuldades presentes quando se tenta responder, seria bem difícil afirmar que a indagação socrática não tem sentido. $\mathrm{O}$ relativista ou o nominalista que tentasse dizer que não concede nenhum significado aos conceitos universais, depois teria de dar conta do fato que usa o mesmo nome para coisas diferentes, e acabaria por se enroscar nas dificuldades evidenciadas no Crátilo. De fato, ninguém é verdadeiramente relativista ou nominalista; tanto é verdade que todos entendem perfeitamente a natureza dos problemas propostos pelas perguntas socráticas e, além do mais, procuram confiantemente arriscar uma resposta. Isso significa, como sabemos pelo Teeteto, que o modo de raciocinar dos homens traz consigo desde sempre uma orientação categórica visando a um objeto estável, universal, imóvel, sempre idêntico a si mesmo (para responder à pergunta socrática não podemos nos contentar com menos do que isso).

Então, como devem ser pensados os objetos desse gênero? A tese fundamental de Platão é que esses objetos, se possuem verdadeiramente as características enunciadas, não podem pertencer ao mundo das coisas materiais. Como sabemos, o mundo físico é intei- 
ramente dominado pelo mobilismo de Heráclito. Então, se a pergunta socrática interroga sobre entidades reais, das quais fazemos verdadeiro uso em nossa vida, deve também existir uma dimensão da realidade que ultrapasse o plano puramente físico: uma realidade que futuramente virá a ser chamada de "metafísica". Esta realidade corresponde àquilo que Platão chama de "ideia": vêm daqui as expressões "mundo das ideias", para indicá-la no seu todo, e "teoria das ideias" para indicar a doutrina relativa a ela.

$\mathrm{Na}$ sua formulação mais simples a teoria das ideias postula a existência de um mundo de objetos imateriais e inteligíveis, qualitativamente diferentes daqueles sensíveis, que mantêm com estes últimos uma relação de unidade a multiplicidade, de universal a particular. Por exemplo, junto das muitas coisas grandiosas, belas ou justas que existem no mundo empírico, existiriam no mundo inteligível (também chamado por Platão de "mundo hiperurânio", ou seja, supraceleste) uma grandeza em si, uma beleza em si, uma justiça em si: tais objetos, únicos e universais, livres do tempo, do espaço e de qualquer forma de devir, representariam aquilo que são realmente, em sua essência pura e não contaminada, isto é, a grandeza enquanto tal, a beleza enquanto tal, a justiça enquanto tal. Em outras palavras, enquanto as coisas grandes, belas ou justas existem temporariamente ou relativamente, as ideias correspondentes a elas existem de modo absoluto e eterno.

De tudo que dissemos conclui-se que a "teoria das ideias" não nasce apenas como resposta às contradi- 
ções do relativismo e do materialismo que está ligado a ele (ver cap. 5), mas também como um desenvolvimento da pergunta socrática e de suas implicações (como vimos há pouco). Mas é opinião difundida, sancionada pelo célebre testemunho de Aristóteles, que Platão foi muito além da posição de seu mestre. Escreve Aristóteles na passagem em questão que, diferentemente de Sócrates, Platão não se contentou em conduzir indagaçōes em busca do universal, mas sustentou também que esse universal possuía uma existência separada (Metafísica, I, 987b), ou seja, separada das coisas sensíveis e é justamente por esse motivo que ele qualifica a posição de Platão, diferenciando-a da de Sócrates, como uma teoria metafísica.

Parece não restar dúvida sobre o princípio de "separação", ou seja, sobre o fato que, para Platão, os conceitos universais, por ele denominados ideias, são objetos que realmente existem, quer além da realidade sensível, quer além da mente humana. Menos óbvia é a consequência que habitualmente se faz derivar dessa tese, ou seja, que as ideias são plenamente conhecíveis pelo intelecto humano; o que significaria que Platão teria superado completamente a fase socrática das perguntas difíceis ou impossíveis de serem respondidas e se teria fixado no âmbito de um saber metafísico preciso, confiável e disponível.

Que essa tese seja, pelo menos parcialmente, errônea, é visível pelo fato que na dita teoria das ideias de Platão há muito pouco que se distinga realmente do exame da pergunta socrática. Quem lê os diálogos per- 
cebe que o autor se demora no exame da pergunta e das suas implicações, e retarda de modo quase irritante a revelação das respostas; ao ponto de parecer que, no final, as respostas nem mesmo existam. De fato, não existe em Platão nenhum lugar onde seja explicitado, por meio de uma definição conclusiva, o conteúdo noético de uma ideia. Por outro lado, a hipótese extrema e oposta, segundo a qual Platão seria fundamentalmente um filósofo cético, é ainda mais improvável, porque, se assim fosse, sua posição não se distinguiria substancialmente dos relativismos e subjetivismos duramente criticados por ele. É claro que, se queremos de verdade entender o pensamento platônico, temos a obrigação de encontrar uma via intermédia entre dois extremos opostos: o conhecimento perfeito da ideia e o radical ceticismo que impede o conhecimento em geral. Em Platão, esta via intermédia é representada de modo eficaz pela doutrina da reminiscência (ou anamnese).

\section{A DOUTRINA DA "REMINISCÊNCIA"}

A doutrina da reminiscência, que pode ser sinteticamente expressa pelo princípio segundo o qual "conhecer é recordar", é exposta por Platão no Mênon e no Fédon e é mencionada outra vez no Fedro. No Mênon é introduzida para solucionar o aparente paradoxo presente no ato de aprender. Como podemos aprender aquilo que ignoramos totalmente? E se não o 
ignoramos, então será já sabido, razão pela qual aprender se torna supérfluo (80e). Nesse diálogo, Sócrates demonstra sua tese com um experimento prático. Um escravo, que nada sabe de matemática, consegue resolver corretamente um problema de geometria apenas respondendo às perguntas de Sócrates, o qual não lhe havia fornecido de antemão nenhum conteúdo que o ajudasse (82b-85b). Isso demonstra que o escravo colocou em prática conhecimentos de que já dispunha desde o seu nascimento (e aqui Platão conecta, como também fez no Fédon, a doutrina da reminiscência com a doutrina da metempsicose, ou melhor, da transmigração das almas de um corpo para outro).

Muito mais elaborada e filosoficamente interessante é a demonstração presente no Fédon (72e-77b). Dizemos que "recordar" é a experiência mediante a qual a noção de uma determinada coisa nos faz vir à mente a lembrança de uma outra diferente. Por exemplo, vendo um objeto pertencente a certa pessoa, lembramo-nos dela, mesmo que a mesma não esteja presente. Esse tipo de rememoração ocorre entre duas coisas diversas. Mas existe também um caso análogo que ocorre entre coisas similares. Por exemplo, se alguém observar uma pintura de Símias, logo sua memória se reporta à imagem de Símias em carne e osso.

$\mathrm{O}$ mesmo gênero de relaçóes pode ser aplicado à relação entre ideias e coisas. Dizemos, por exemplo, que o igual é alguma coisa, significando não a igualdade concreta de madeiras ou pedras, mas alguma coisa de diferente e de ulterior em relação a todas essas 
igualdades, ou seja, o igual em si, e assim conhecemos o que é (74a-b). Esse igual nos vem à mente, a saber, "é recordado", a partir das igualdades que vemos no mundo empírico (mais ou menos como o retrato de Símias relembra o Símias real).

Por outro lado, a experiência não pode ser a verdadeira fonte de onde aprendemos a noção do igual em si, porque os casos de igualdade que provamos através da experiência são todos deficitários em relação à igualdade perfeita, e nós percebemos essa falha (74d-e). Essa percepção é possível, porém, apenas se possuirmos antecipadamente a noção da igualdade em si, sem a qual não podemos dizer que os iguais concretos são defetivos. Isso significa que "antes de nascer e logo depois de nascido, já conhecíamos não só a igualdade e, por conseguinte, o maior e o menor, mas também todas as coisas desse gênero; porque não se trata de raciocinar só sobre o igual, mas também sobre o belo em si e o justo em si, o sagrado, em suma, como dizia, sobre todas as coisas às quais nós, interrogando e respondendo, damos o sigilo da expressão 'aquilo que é"” (75c-d).

Resulta necessário que no ato do nascimento o homem possua de algum modo as ideias. A experiência nos comprova que não se pode tratar de um inatismo perfeito, ou seja, de um saber já realizado desde o início, porque os homens nascem ignorantes e aprendem no decorrer do tempo. Mas pelo fato de o homem não poder nascer sob um estado de completa ignorância (até porque, se fosse assim, a aprendizagem seria inex- 
plicável), devemos pensar em uma forma intermediária entre saber e não saber, como no caso em que alguém teve um saber pleno, mas agora se esqueceu. O trauma do nascimento é a causa desse esquecimento que, porém, não anula totalmente os resquícios do saber, o qual, de certa forma, será rememorado a partir do contato com a experiência.

Eis a via intermédia que procurávamos. Não é de se espantar que os homens não consigam responder completamente à pergunta socrática, e que não se encontre nos escritos platônicos a definição de uma ideia. Os objetos aos quais esta pergunta se refere, de fato, têm uma natureza metafísica, ou seja, não estão atualmente disponíveis ao conhecimento da alma encarnada. $\mathrm{O}$ que não significa, todavia, que os homens não possuam de todo alguma noção. Em suas almas estão presentes as recordações esmaecidas de tudo o que viram antes de nascer. Isto explica porque eles conseguem entender do que se trata quando se alude a conceitos universais, mesmo não tendo tido uma experiência atual, e também porque são capazes de exprimir opiniōes sensatas sobre $\mathrm{o}$ assunto (embora não possam conhecê-lo de modo exaustivo). A análise de outras passagens do Fédon nos permitirá confirmar esta conclusão. 


\section{A COGNOSCIBILIDADE DAS IDEIAS NO FÉDON}

Exercitar-se para a morte é a característica dos filósofos, sustenta Sócrates no início do diálogo. A razão principal disso é que o filósofo (lembremos o amante da sabedoria) poderá finalmente conhecer os objetos que procura só depois da morte. Porquê? Porque os filósofos desejam conhecer as ideias e tal conhecimento só é acessível (pelo menos em sua completude) à alma desencarnada: "[...] enquanto tivermos o corpo e nossa alma estiver misturada e confundida com um mal dessa natureza, nunca seremos capazes de conquistar totalmente aquilo que desejamos e que acreditamos ser a verdade"; logo, "das duas uma, ou não é possível em nenhum caso conquistar o saber, ou somente será possível quando estivermos mortos; porque só assim a alma estará completamente sozinha em si mesma, desvencilhada do corpo, antes disso não" (66b-67a).

Particularmente explícita é a segunda dessas passagens, onde se diz que o homem, enquanto possuir o corpo, não pode "ver a verdade". Certamente se poderá dizer que entre o não ver e o ver existam medidas intermediárias e que mediante o estudo e a pesquisa, os homens poderão refinar e tornar progressivamente menos impuras as recordações presentes em suas almas. Mas o fato persiste: para Platão, se os homens abandonarem os habituais preconceitos e se aplicarem à filosofia, encontrarão ótimas razões para defender "que" as ideias existem; ainda assim, encontram muitas 
dificuldades (precisamente porque as ideias são objetos que existem em estado puro somente além do mundo físico) quando se trata de entender "o que" são as ideias (ou seja, quando se trata de encontrar uma completa e conclusiva definição dos conceitos universais).

\section{O CONHECIMENTO DAS IDEIAS NO FEDRO E NA CARTA VII}

Segundo uma tese bastante difundida, Platão teria progressivamente abandonado a doutrina da reminiscência, substituindo-a pelo método dialético. Como veremos mais adiante (ver cap. 11, pp. 155-6), essa tese geralmente não é aceitável, porque a reminiscência e a dialética desenvolvem papéis distintos no pensamento de Platão. No entanto, podemos observar que a doutrina da anamnese está presente também no Fedro, que quase certamente pertence ao período da velhice de Platão. No grande mito cósmico-escatológico presente na parte central desse diálogo, diz-se que as almas conseguem ver as ideias quando, ainda não encarnadas em um corpo, se movem no mundo hiperurânio seguindo os deuses (249b-c). Mas, uma vez encarnadas, já não dispõem mais dessa visão. Para superar essa dificuldade, deve-se recorrer ao auxílio da memória incentivada pelo exercício dialético. Esse exercício, se bem aplicado, poderá desenvolver a mesma função de estímulo que no Fédon era atribuída à experiência sensível. 
Para confirmar o fato que Platão nunca abandonou essa condição intermediária a propósito do problema cognitivo, podemos defender-nos com o breve, mas denso excursus filosófico presente na Carta VII (342a344d). Trata-se de um documento muito interessante, porque se essa carta é autêntica, como parece ser, estamos diante daquele que talvez seja o último tratamento platônico do assunto, mais autoral ainda pelo fato que, finalmente, Platão se exprime em primeira pessoa, sem a mediação do diálogo e das suas personagens.

Nesse documento Platão diz que há quatro instrumentos para conhecer as coisas: o nome, o discurso, a imagem e o conhecimento propriamente dito. É importante, sobretudo, o último desses elementos, porque compreende a ciência, o intelecto e a opiniāo verdadeira. O conhecimento propriamente dito representa o aspecto subjetivo do conhecimento, aquele pelo qual todo conhecimento é sempre ciência, intelecção e opinião de alguém. Segundo Platão, nenhum desses quatro elementos, nem mesmo todos tomados juntos, corresponde ao quinto, ou seja, à coisa em si mesma. Isso acontece porque tais elementos mostram sempre, junto com a essência da coisa, também a sua qualidade (342e), por isso, não existe nenhum discurso capaz de exprimir a coisa em seu estado puro, como ela é em si e por si. A este propósito, Platão fala de "fragilidade dos logoi ["discursos"]".

Como se pode ver, a questão aqui discutida ainda é a da pergunta socrática. Essa pergunta tem por objetivo a busca da essência, mas as respostas terminam 
desviando-se em direção a algo que não é a essência da coisa, por exemplo, acabam por ressaltar somente determinadas qualidades. Mesmo o conhecimento da coisa, ou seja, o quarto elemento, não é a coisa, mas é somente o conhecimento da coisa como ela aparece na intuição ou na opinião de alguém. Isso significa, de acordo com o Fedro e com a doutrina da reminiscência, que tudo aquilo que o homem pode conhecer sobre as essências está vinculado à rememoração individual, e jamais poderá se tornar um conhecimento objetivo, disponível, indiscutível, como acontece com os objetos que todos podem ver e que para todos aparecem sempre do mesmo modo.

\section{RECORRENDO AOS LOGOI: \\ A “SEGUNDA NAVEGAÇÃO” NO FÉDON}

No parágrafo anterior falamos de logoi (discursos) e de sua natureza. Esse tema nos conduz novamente a uma passagem do Fédon que já conhecemos em parte, ou seja, à dita autobiografia intelectual de Sócrates, onde o filósofo manifesta sua desilusão em relação às doutrinas dos físicos pré-socráticos. Para sair dessa situação, Sócrates empreende a chamada "segunda navegação” (99c-d), uma metáfora que serve para indicar um percurso mais longo e fatigante (esta expressão era aplicada à navegação a remos, à qual se recorre na ausência de vento).

Antes de ir diretamente ao ponto, com uma nova metáfora Sócrates mostra que se trata de um caminho 
muito difícil: ele declara ter feito como aqueles que tentavam contemplar o sol durante um eclipse e que, para não cegarem, se limitavam a observar somente a imagem refletida. Temendo que a mesma coisa sucedesse também à sua alma se tivesse tentado "observar diretamente as coisas com os olhos e procurasse apreendê-las com cada sentido", Sócrates decide usar um filtro adequado ao conhecimento intelectivo: "Pareceu-me necessário refugiar-me nos discursos (logoi) e considerar que se achava neles a verdade das coisas existentes" (99e).

A expressão "a verdade das coisas existentes" e a metáfora visual relacionam diretamente o discurso que aqui se desenvolve com aquela passagem do Fédon que analisamos, onde Sócrates disse que é impossível ao homem vislumbrar a verdade enquanto estiver vivo. O sentido dessa passagem é que a tentativa de ver diretamente a essência das coisas fracassa, porque a visão do homem termina sempre e só por se desviar para as únicas coisas que são verdadeiramente visíveis para ele, isto é, as coisas materiais. Assim sendo, não nos resta senão virar-nos para uma via indireta, ou seja, a dos logoi.

Todavia, não podemos dizer que os logoi oferecem um conhecimento - em termos absolutos - inferior ao dos sentidos (99e-100a). De fato, os logoi referem-se, pelo menos, àquela realidade que verdadeiramente é e àquilo que realmente é causa, enquanto que a percepção sensível está bem mais distante da verdade, além de ser mais deformadora, porque apreende a realidade sempre móvel, que não se pode dizer verdadeiramente 
o que é. Os logoi também não são as ideias, mas sim os discursos e raciocínios que permitem estabelecer que as ideias existem. Com efeito, a execução do programa esboçado aqui, ou seja, o de encontrar as causas da realidade por meio dos logoi, permite simplesmente dizer (ver cap. 5, pp. 55-7) que a razão do grande é a grandeza, do pequeno a pequenez, do dois a dualidade, etc. Não existe nenhuma tentativa de descrever os entes identificados daquela maneira, com base em uma suposta visão inteligível superior à sensível; só há a afirmação que eles existem e que são verdadeiras as causas que dizem que eles existem dessa forma.

\section{QUE TIPO DE ENTES SÃO AS “IDEIAS” DE PLATÃO?}

A teoria das ideias de Platão é considerada a primeira metafísica da filosofia ocidental. Todavia, o termo "metafísica" não se encontra nem em Platão nem em Aristóteles, mas nasce de complexos episódios editoriais ligados à obra de Aristóteles que leva esse nome. Mas o seu significado é suficientemente claro. É chamada de metafísica, em seu senso estrito, uma doutrina que postula a existência de objetos que se situam para além do plano físico (em grego, metà tà physiká), geralmente em uma dimensão da realidade superior àquela mundana. Considerando a palavra sob essa acepção, o início da metafísica coincide com a superação da posição pré-socrática, segundo a qual as causas 
da existência poderiam ser identificadas no âmbito da realidade sensível, e através da pesquisa contextual de suas diversas causas, superiores a essa dimensão. Desse ponto de vista, o primeiro texto metafísico ocidental é o Fédon, onde essa mudança de perspectiva é evidente de várias formas.

A apresentação que fizemos da doutrina platônica das ideias tinha precisamente o escopo de respeitar a sua natureza metafísica. Essa natureza foi colocada em discussão por filósofos e estudiosos mais de uma vez, sobretudo nestes últimos dois séculos. As ideias platônicas foram progressivamente interpretadas como conceitos puros; como axiomas, hipóteses, definiçôes, significados; como formas a priori do intelecto; como representaçôes puras; como objetos noéticos comparados aos entes matemáticos, etc.

Em todas essas interpretações, supõe-se que as ideias são objetos acessíveis ao conhecimento, como termos de referência de uma intelecção pura, indiferente aos condicionamentos psicológicos e históricos. De tal modo, a identidade e a intemporalidade das ideias que, em Platão, derivam da sua pertença a um mundo diferente do mundo sensível, são transportadas para o plano da lógica e da gnoseologia, razão pela qual as ideias platônicas são eternas assim como são eternos os conceitos, mas não se pode dizer que tenham uma verdadeira existência fora das relações cognitivas. Se assim fosse, a teoria platônica das ideias não seria senão uma forma particular de epistemologia, isto é, uma doutrina que se encarrega simplesmente de iden- 
tificar e descrever os esquemas conceituais dos quais nos servimos para interpretar o mundo. As ideias, em outras palavras, mesmo sendo difíceis de identificar, seriam, de certa forma, uma espécie de instrumentos à nossa inteira disposição; e, com base nessa disponibilidade, os homens poderiam confiantemente enfrentar o desafio do conhecimento filosófico do mundo sem encontrar obstáculos estruturais.

Mas esse tipo de interpretação possui o defeito de ignorar a dimensão transcendente (neste sentido, metafísica) da teoria. Ora, o aspecto que qualifica a "transcendência" platônica é que, nela, os objetos transcendentais são os universais, ou seja, exatamente os instrumentos que seriam necessários para atingir um conhecimento metafísico da realidade e para construir uma teoria metafísica de qualquer tipo.

Disso deriva uma importante série de efeitos. Em primeiro lugar, a metafísica de Platão, como se lê na Carta VII, reduz-se a pouquíssimas proposições (344e). Em segundo lugar, a metafísica possui, em Platão, o aspecto predominantemente de apelo e provocação, de uma dialética interminável entre realidade sensível e mundo ideal, estruturalmente incapaz de apossar-se do mundo ideal com os meios infalíveis da ciência e do conhecimento plenamente desenvolvido. Por fim, a metafísica de Platão não pode absolutamente valer como verdade dogmática e definitiva, como conhecimento infalível de uma realidade perfeita e eterna que impóe um fim à pesquisa e elimina todas as objeções. 
A natureza metafísica das ideias platônicas leva também a excluir - se se admitir que se trata de realidades dotadas de existência própria - que as ideias possam ser consideradas análogas às substâncias sensíveis. Essa analogia incorreta poderia ser sugerida pela sua faculdade de autopredicação. Um par de exemplos serão suficientes para explicar esse ponto. No Protágoras 329c, Sócrates pergunta ao sofista se a justiça em si é justa ou injusta, enquanto que no Fédon 100c, se diz que o belo em si é belo ele mesmo. Isso significa que é possível predicar da ideia a qualidade que ela mesma representa. Ora, tal circunstância parece ser a prova evidente do fato que as ideias platônicas são substâncias análogas às físicas; de fato, comportam-se da mesma maneira, isto é, como objetos dotados de atributos.

A principal dificuldade contida nessa tese é o argumento chamado "terceiro homem" (segundo a denominação que lhe deu Aristóteles, Metafísica I, 990b; ver cap. 11, p. 141). Se o conceito da beleza, ou seja, aquilo que torna belas as coisas que dela participam, fosse também ele uma coisa bela, seria necessário outro belo (um "terceiro" belo além da coisa bela e do conceito de beleza), do qual o conceito de beleza teria de participar para ser chamado belo, e assim ao infinito.

Os críticos modernos estudaram profundamente o aspecto lógico desse argumento e tentaram explicar e justificar de várias maneiras a posição platônica 
trabalhando nesse plano. Mas provavelmente não é a estratégia mais adequada, porque não leva em conta o fato que a filosofia de Platão pertence a um contexto teórico e linguístico muito mais fluido que o nosso, no qual determinados pressupostos ainda não tinham sido codificados. Com efeito, a análise moderna da autopredicação e a dificuldade do terceiro homem já pressupunham que Platão tivesse a intenção de falar das ideias em termos de substância/atributos, sujeito/ predicados. Sendo assim, dizer que a ideia do belo é bela significará simplesmente considerar aquela ideia uma substância/sujeito com o predicado/atributo da beleza. Mas é bem possível que a autopredicação em Platão pretendesse ter um significado diferente.

Com efeito, em Platão a autopredicação não possui um significado lógico, mas metafísico. Aquilo que ele pretende dizer é que, se existe algo que possa ter o direito de ser chamado de belo ou justo, esse algo é justamente a beleza ou a justiça enquanto tais (ou seja, a beleza e a justiça transcendentes), porque nenhuma das coisas belas é perfeita e inteiramente bela. A autopredicação, em outras palavras, é um modo expressivo escolhido para evidenciar a fratura existente entre a imperfeição do mundo sensível e a perfeição do mundo ideal: aquilo que é belo no mundo sensível (no exemplo de Hípias, a bela mulher), por um lado, não é unicamente e sempre belo, e, por outro, não representa tudo aquilo que é belo. Logo, podemos dizer que só a beleza em si "é bela e ponto final". Essa concepção, uma vez interpretada em termos lógicocategoriais, revela-se absurda, porque em tal contexto, 
é evidente que o belo é um predicado e não uma realidade existente por si só (como pretendem ser as ideias platônicas). Eis assim um outro caso no qual a marginalização dos aspectos metafísicos da teoria das ideias nos impede de apreender o seu verdadeiro alcance.

\section{A TEORIA DAS IDEIAS: UMA ONTOLOGIA OU UMA FILOSOFIA DOS VALORES?}

Já vimos que, segundo Aristóteles, Sócrates se interessava exclusivamente por questôes éticas. Mas também o Sócrates de Platão, particularmente aquele representado nos diálogos da juventude, direciona sua típica pergunta exclusivamente para o âmbito dos valores. A teoria platônica das ideias parece compartilhar dessa orientação. $\mathrm{Na}$ verdade, as ideias mais citadas por Platão são as ideias de valor. É de se suspeitar que seu interesse principal fosse direcionado propriamente a esse gênero de universais. Como vimos em uma passagem do Fédon citada anteriormente, se é verdade que os objetos da indagação são também o igual, o maior e o menor, é também verdade que aquilo de que importa falar é do belo, do bom, do justo e do santo enquanto tais $(75 \mathrm{c}-\mathrm{d})$. Tudo isso significa que Platão se interessara pela teoria das ideias, sobretudo como um instrumento para conseguir detectar os cânones de caráter ético.

Uma vez que as ideias representam em geral a unidade em relação à multiplicidade, o universal em rela- 
ção ao particular, é claro que os motivos lógicos pelos quais se deve ter uma única ideia de justiça em relação às tantas ações justas, devem poder valer para todo e qualquer objeto, inclusive para aqueles privados de relevância ética. Surge então um problema. As ideias representam o valor exatamente enquanto ideias, na medida em que são superiores à realidade sensível? Ou o mundo das ideias é uma formulação da realidade sensível complexivamente pensada, no interior do qual se reproduz o mesmo contraste entre valor e desvalor (por exemplo, entre ideia de justiça e ideia de injustiça) que existe na realidade sensível?

Para Platão, não há dúvidas de que o mundo das ideias é superior à realidade sensível também em termos de valores. Era convicção entre os gregos que o bom fosse também belo, tanto que o vocábulo grego kalón, "belo", possuía também um significado ético. Aquilo que é belo e bom, por sua vez, é tal, porque possui forma e realidade definida, limitada, precisa; porque nele se manifestam ordem e racionalidade. Essas concepções foram elaboradas pelos pitagóricos, que não só haviam indicado o número como essência de todas as coisas, como haviam também interpretado a realidade inteira como uma harmônica proporção matemática. Em um contexto similar, é claro que aquilo que é racional e ordenado se diferencia daquilo que é irracional e desordenado, porque é mais unitário, é menos afeito à multiplicidade inumerável e indefinida e manifesta uma organicidade e uma estrutura homogênea. Esses são, precisamente, os traços característicos das ideias. 
A relevância desse princípio já é bem clara desde as primeiras elaboraçōes da teoria das ideias, nas quais unidade, identidade e imobilidade são percebidas como atributos positivos. No Fédon, diz-se que a realidade ideal é invisível (79a), pura, eterna, imortal, invariável (79d), divina, inteligível, uniforme, indissolúvel (80b). Essas características estão todas carregadas de valores e todas podem ser deduzidas, em última análise, da unidade da ideia: o múltiplo é impuro, mutável, corruptível, variável, material, sensível, disforme, etc.

Recorrer a essas motivaçóes pitagóricas permite a Platão encontrar uma mediação entre o ponto de vista do ser e o dos valores. Mas a segunda perspectiva permanece privilegiada. Não é um caso que, n'A República, Platão estabeleça como princípio metafísico mais elevado não o ser em geral e tampouco um ser de natureza superior (por exemplo, deus), mas o bem (ver cap. 7, pp. 84-6). A mesma exigência é bem visível também na progressiva transformação da doutrina das ideias em uma doutrina de princípios de cariz matemático, que Platão inaugura nos diálogos dialéticos e depois aprofunda nas doutrinas orais.

Sobre esse tema, particularmente emblemática é uma passagem do Parmênides. Depois de Sócrates ter introduzido as ideias como um instrumento para resolver as aporias de Zenão (ver cap. 11, pp. 139-40), Parmênides (o condutor do diálogo) pergunta a Sócrates até onde pode ser estendido o campo das ideias: i) Existem ideias de igualdade e de outros conceitos matemáticos como a unidade, a multiplicidade, etc.? ii) Existem também ideias de valor, como o belo e o 
bom? iii) (O que dizer sobre as coisas neutras como o homem, o fogo, a água? iv) Ou pior ainda, existem ideias das coisas mesquinhas e feias como a lama, o cabelo, a sujeira? Sócrates responde afirmativamente aos dois primeiros níveis de ideia apresentados, tem dúvidas quanto ao terceiro, e nega terminantemente que existam ideias do quarto gênero (130d).

Os dois primeiros gêneros de ideia são facilmente reconduzíveis ao âmbito dos valores: o segundo de maneira direta, o primeiro mediante a relação de tipo pitagórico (como vimos) que existe entre conceitos matemáticos como o uno, o limite, a medida e aquilo que é belo e bom. O modo resoluto com o qual o jovem Sócrates aceita as ideias matemáticas e morais poderia significar que a "doutrina das ideias" tem um caráter eminentemente axiológico, ou seja, que tem como escopo a identificação, nas ideias, daqueles valores absolutos que servem de modelo para a vida ética e política.

Isso é confirmado, diferentemente de quanto acreditamos, também pela resposta de Parmênides. $\mathrm{Na}$ verdade, ele não convida seu interlocutor a postular decididamente ideias de todas as coisas (ou seja, a resolver o conflito entre ontologia e doutrina do valor a favor da primeira). Mas convida-o a não desprezar nenhuma das realidades que nomeou: portanto, nem mesmo a lama e a sujeira (130e). Convida-o a encontrar um modo para definir os princípios capazes de demonstrar o valor, mesmo que ele seja relativo, de todas as coisas (como veremos, aqui há uma antecipação do Timeu): para assim ampliar e especificar a 
compreensão da realidade do ponto de vista do valor, certamente não para abandoná-la ou redimensioná-la.

Esse trecho do Parmênides que estamos comentando nos permite, então, confirmar a hipótese introduzida antes, ou seja, que Platão preferia privilegiar, na sua metafísica, o aspecto axiológico (ou seja, o aspecto pelo qual ela é um método para a pesquisa dos valores) em detrimento do ontológico (isto é, o aspecto pelo qual ela é uma doutrina geral do ser). Aqui se manifesta um aspecto característico da metafísica platônica. Essa não tem tanto o escopo de responder à pergunta “o que é o ser?", quanto o escopo de justificar a emergência de sentido e de valor já implícitos na experiência que, como acredita Platão, sem recorrer aos princípios metafísicos não poderiam ser explicados e compreendidos. 
(Página deixada propositadamente em branco) 


\section{CAPÍTULO VII}

\section{METAFÍSICA E EPISTEMOLOGIA \\ N'A REPÚBLICA}

INTRODUÇÃO

O CAPÍTUlo ANTERIOR EXPUSEMOS AS LINHAS
fundamentais da metafísica de Platão e da teoria
das ideias que constituem seu eixo principal (ao me-
nos até A República). Na base dessa teoria está o prin-
cípio segundo o qual existem duas zonas da realidade
providas de características diferentes e organizadas se-
gundo uma escala hierárquica: em posição dominante
temos o mundo das ideias, ou seja, entidades imate-
riais, unitárias e sempre idênticas a si mesmas; em um
plano inferior, temos a realidade sensível, imperfeita,
múltipla e mutável. Essa subdivisão comporta tam-
bém uma distinção análoga sobre o plano do conheci-
mento: à dimensão mundana corresponde o conheci-
mento que se desenvolve por meio dos sentidos (doxa, 
ou opinião), ao mundo das ideias corresponde o conhecimento construído apenas com base no intelecto (episteme ou ciência). Também já mencionamos o fato de que essa segunda distinção é totalmente válida para o plano teórico, mas nem tanto para o prático: existindo de fato as ideias dos objetos metafísicos, o conhecimento intelectual que o homem possui em sua dimensão mundana está destinada a permanecer sempre aproximativa e imperfeita.

Porém, esse estado de coisas não impede Platão de tentar articular melhor os graus de realidade e as faculdades cognitivas a eles associadas (pelo menos, em linha de máxima), no interior do dualismo geral que permeia sua metafísica. A esse tema é dedicada a célebre metáfora da linha dividida, presente no final do livro VI d'A República (509e-511e).

\section{A METÁFORA DA LINHA}

Para esclarecer a diferença entre sensível e inteligível, Sócrates imagina desenhar um segmento e dividilo em duas partes (que correspondem justamente ao sensível e ao inteligível) e, em seguida, divide cada uma dessas partes novamente em duas. Na parte inferior do segmento, correspondente à realidade sensível, encontram-se a faculdade inferior da imaginação (eikasia) e aquela relativamente mais elevada da crença (pistis). As sombras e os reflexos correspondem à imaginação, ou seja, as imagens dos objetos materiais e 
naturais (animais, plantas etc.), os quais, porém, são objetos de crença. Tudo isso representa o mundo da doxa, razão pela qual, em primeira instância, a metáfora da linha enuncia a divisão principal da gnoseologia platônica (mundo sensível : opinião = mundo inteligível : ciência).

A segunda parte da linha apresenta problemas que não são tão fáceis de resolver. Ao final da sua exposição (511d-e), Sócrates define as duas faculdades inteletuais, movendo-se de baixo para cima, com os termos dianoia e noesis (ambos significam "pensamento"). Segundo a interpretação mais difundida, a dianoia seria um pensamento de caráter discursivo, teria por objeto os entes matemático-geométricos, enquanto a noesis seria um pensamento de caráter intuitivo e teria como principal objeto verdadeiramente as ideias.

$\mathrm{Na}$ realidade, essa maneira de interpretar a diferença entre dianoia e noesis não é muito persuasiva. Se os geômetras conduzem suas demonstrações através de figuras, não se percebe por que é que logo eles precisam de fazer uso de um pensamento discursivo. Também é difícil de entender por que sujeitos que estudam as ideias, exercitando a forma de conhecimento mais elevada que, na sequência desse livro, será definida constantemente como "dialética" (com claras referências ao ato de dia-legesthai, ou seja, "à troca de discursos"), devam fugir ao pensamento discursivo e ater-se às intuições. Com efeito, a interpretação que mencionamos não se encontra exposta no texto.

Em primeiro lugar, Sócrates cita os entes matemáticos apenas a título de exemplo (embora signi- 
ficativos), para se fazer entender por Gláucon, mas esses entes não desempenham um papel essencial no esquema (510c-e). Em segundo lugar, a noesis, não é descrita como conhecimento intuitivo, mas como conhecimento que se exercita pelo logos e pela capacidade de discutir (511b). Sobretudo, a diferença entre a dianoia e noesis não tem nada a ver com a diferença entre o conhecimento proposicional e o conhecimento não proposicional. Dianoia, antes de tudo, significa pensamento em geral. O termo noesis é introduzido por Sócrates para distinguir, dentro do pensamento em geral, um pensamento de tipo particular: trata-se do pensamento que não se move a partir de hipóteses (de natureza sensível) em direção ao baixo, isto é, para o mundo da experiência, mas se move em direção ao alto, à procura do princípio não hipotético, e depois se desenvolve como processo alternado de sínteses (do múltiplo ao uno), inteiramente inserido no âmbito das ideias (511b; ver também 532a-b).

Então, entende-se porque, mesmo não sendo essencial, é útil mostrar a diferença entre as duas formas de pensamento através do exemplo da geometria. Existe um método que estabelece seus princípios como puras hipóteses e depois, fazendo uso de figuras e imagens, deduz as propriedades das hipóteses que estabeleceu. Mas esse não é o pensamento em seu grau mais elevado. De fato, assume a existência de certas coisas (figuras geométricas) sem demonstrar sua necessidade, pois está ainda ligado às representações oferecidas pelas figuras (que, obviamente, são retiradas do mundo sensível). Essas características, entendidas de 
maneira inversa, dizem como o intelecto deve se aproximar das ideias: não deve assumi-las como simples hipóteses (ao invés, deve mostrar que existem necessariamente, como Platão tentou fazer com a doutrina da reminiscência) e deve servir-se apenas do logos, sem usar figuras sensíveis ou mentais.

$\mathrm{Da}$ análise desse trecho, podemos chegar a duas conclusōes: 1) a forma mais elevada de saber (noesis) possui caráter discursivo/proposicional, mas não intuitivo; 2) não existe uma diferença real entre os objetos tratados pela dianoia e aqueles estudados pela noesis: dado que ambas as noçôes indicam o pensamento e dado também que o pensamento só pode se ocupar dos inteligíveis, o objeto das duas faculdades deve ser o mesmo. A única diferença será em relação ao método e consiste precisamente no fato de que somente a noesis considera os inteligíveis como ideias puras e os trata de forma apropriada.

\section{A ALEGORIA DA CAVERNA}

N'A República, logo depois da exposição da metáfora da linha, o livro seguinte (o VII) debuta com Sócrates introduzindo a célebre alegoria da caverna. Platão imagina uma caverna, onde os prisioneiros se encontram acorrentados de costas para a entrada. Às suas costas, na entrada, existe um pequeno muro ao longo do qual uns homens transportam objetos erguidos acima do muro e conversam entre si. Atrás deles, 
existe um fogo, graças ao qual, os prisioneiros podem ver no fundo da parede da caverna as sombras dos objetos e ouvir as vozes propagadas pelo eco. Se esses prisioneiros, desde sempre habituados a ver somente as sombras, fossem improvisadamente desacorrentados e soltos, fossem obrigados a levantar-se e a olhar para os objetos reais, dos quais antes viam só o reflexo e a luz que os iluminava, suas vistas seriam ofuscadas, não enxergariam bem e continuariam a considerar que a verdadeira realidade era a que viam antes e não a que veem agora. Se depois fossem levados para fora da caverna, seus olhos seriam cegados pelos raios do sol e não conseguiriam ver os objetos que nós consideramos pertencentes ao mundo real: por isso, teriam de se habituar lentamente, primeiro observando os objetos através do seu reflexo; depois, à noite, os corpos celestes como as estrelas e a lua, e só depois poderiam contemplar o sol. Não mais através da sua imagem refletida na água, mas tal como é na sua residência.

$\mathrm{O}$ aspecto da alegoria sobre a qual Sócrates se concentra no início (514a) é a condição de estranheza e de incompreensão recíproca entre filósofos ("educados") e não filósofos ("não educados"): o não filósofo está habituado a seu mundo (o da caverna) e não quer deixá-lo; quando é levado para fora, devido à dor e fadiga da nova experiência, não encontra nada de gratificante, e deseja voltar para dentro do seu antro. O filósofo, ao contrário, vive em um mundo completamente seu e não deseja se misturar aos outros homens (assim como se lê também no célebre retrato do filósofo que encontramos no Teeteto $173 \mathrm{~b}-177 \mathrm{c}$ ). 
Torna-se instigante, e em parte permitido também pelas explicações que Sócrates dá em seguida (ver 532d-b), verificar se entre a caverna e a linha existe alguma correspondência. $\mathrm{O}$ mundo no interior da caverna, por exemplo, é claramente o mundo sensível, e o mundo externo seria aquele inteligível. Por conseguinte, a fogueira simboliza o sol, e o sol a ideia do bem (que no sexto livro é justamente descrita por essa metáfora, da qual falaremos em seguida). Restam quatro elementos significativos na alegoria da caverna, exatamente como os graus da linha: as sombras na parede da caverna, os objetos carregados pelos transportadores, as sombras e reflexos fora da caverna, e as coisas reais no mundo externo. Aqui, porém, a tentativa de encontrar correspondências precisas fracassa. As sombras que se formam sobre a parede da caverna deveriam corresponder aos reflexos e às sombras que são objeto da eikasia, mas isso é inviabilizado pela afirmação explícita de Sócrates, segundo a qual a condição dos prisioneiros é idêntica à nossa atual (515a): mas nós vemos também as coisas reais, não somente sombras e reflexos. Seria necessário, assim, considerar que as sombras na parede correspondem às coisas sensíveis: mas, assim, não saberíamos como classificar os objetos que passam sobre o muro. Também a correspondência com os elementos externos é problemática. Essa depende, de fato, da hipótese que as duas faculdades intelectuais da linha tenham dois objetos diferentes e, em particular, que a dianoia se refira aos entes matemáticos: assim poderia haver uma correspondência entre esses entes e os reflexos e as sombras presentes do 
lado de fora da caverna. Mas, como vimos, a ideia de que na metáfora da linha se fale verdadeiramente de objetos inteligíveis diferentes das ideias não é nada segura.

Essa deformidade, porém, não deve ser subestimada. Por um lado, a natureza e a função da alegoria enquanto tais impedem que seu conteúdo seja perfeitamente traduzido em conceitos abstratos. Por outro, como vimos, o principal escopo dessa alegoria é mostrar a diferença de "educação" entre filósofos e não filósofos. É justamente a esse argumento que se dedica a segunda parte do livro VII.

\section{A EDUCAÇÃO DOS FILÓSOFOS}

Como veremos no capítulo 10, a educação dos filósofos é tratada n'A República em conexão com o tema político da cidade ideal (na qual compete justamente aos filósofos o papel de governar). A formação específica dos governantes-filósofos centra-se sobretudo em um conjunto de disciplinas que na Idade Média será chamado de "quadrivium": aritmética, geometria, astronomia e música. A quinta e mais elevada dessas ciências é a dialética. As ciências matemáticas possuem um escopo essencialmente preparatório: conduzir a alma para a compreensão puramente intelectiva (523a). Para essa finalidade é particularmente apropriado o estudo de coisas que suscitem impressões contraditórias. Aqui Platão se religa ao discurso que já havia feito no Fédon, quando havia evidenciado - embora sob outro 
ponto de vista - as contradições inerentes à percepção sensível (ver cap. 5, pp. 55-7). Visto que apenas com a ajuda dos sentidos a alma não é capaz de resolver essas contradições, é obrigada a ver o grande e o pequeno separadamente, por meio do intelecto (524c). Mediante esse exercício, a alma compreende a necessidade de pôr uma realidade e uma ordem inteligível junto à realidade e à ordem sensível, pois nisso consiste o seu extraordinário valor educativo.

Assim delimitado, o processo corresponde àquilo que na alegoria da caverna fora designado como conversão de toda a alma na direção de outro âmbito de objetos, isto é, na direção do ser e da verdade (525c); que é, pois, o âmbito daquilo que é sempre em contraposição àquilo que nasce e morre (527b). É importante observar que, para Platão, as quatro ciências citadas há pouco possuem todas um caráter matemático; incluindo as duas últimas que se ocupam não apenas de objetos sensíveis (como os astros), mas também das proposições e das mais puras relações numéricas que podem ser identificadas mediante o estudo daqueles objetos. Além do mais, Platão evidencia que a natureza das ciências mencionadas deve ser tal, para que sejam verdadeiramente adequadas à promoção do saber, e que devem libertar-se quer do seu interesse pelas coisas sensíveis enquanto tais, quer de sua finalidade prática (reservando-se, para a aritmética e a geometria, uma utilidade limitada para fins militares).

No que diz respeito à dialética, n'A República Platão é moderado nas informações (sobre isso, tornará 
a discutir mais abundantemente nos diálogos dialéticos). Mas existe uma característica geral que aparece particularmente evidenciada. Já na análise das outras ciências, assim como no mito da caverna, a dialética se configura muito mais como o ato de dialegesthai, ou seja, de discutir, do que como uma ciência noética pura (525d, 528a). Da mesma maneira, quando Platão começa a falar diretamente da dialética como o gênero de saber mais elevado, para a definir ele utiliza uma fórmula na qual a alusão ao ato concreto do dialogar, do interrogar e do responder não poderia ser mais clara: exclui-se do saber mais elevado (isto é, do objeto da dialética) quem (literalmente) "não é capaz de dar e receber razão - ou de fazer discurso (logos) com as mesmas caracterísicas" (531e). É justamente essa capacidade técnica que permite aos homens, como no mito da caverna, alcançar com o intelecto o limite daquilo que é inteligível, assim como a visão chega aos limites do visível (532a-b).

\section{O SABER DO FILÓSOFO: CIÊNCIA E OPINIÃO, FILÓSOFOS E FILODOXOS}

Tanto a metáfora da linha quanto a alegoria da caverna fazem alusão à estrutura metafísica de que falamos, ou seja, aludem à existência de objetos puramente inteligíveis, em um mundo superior. Mas, enquanto na metáfora da linha, o discurso parece limitado à descrição de uma escala ascendente de graus de realida- 
de e de funções cognitivas correspondentes, como se Platão quisesse sobretudo explicar qual seria o modo correto para tentar conhecer as ideias (sem colocar a questão de estabelecer até que ponto tal tarefa é realizável), a alegoria da caverna evidencia explicitamente a natureza metafísica da separação de ideias e sensíveis: se, de fato, as ideias correspondem aos objetos naturais que os prisioneiros, uma vez livres, contemplam do lado de fora da caverna, se é verdade que a condição no interior da caverna corresponde àquela atual de nós homens, logo será evidente que os homens podem conhecer diretamente (ou seja, visualmente, de maneira direta) as ideias somente quando saírem da sua dimensão terrena.

É verdade que na alegoria da caverna se supõe que o filósofo seja capaz de realizar esta viagem e depois voltar para educar seus semelhantes, e isso faria pensar que a passagem do mundo físico ao metafísico estivesse aberta também a homens de carne e osso. Mas isso não é obrigatório, visto que contradiz os alicerces da metafísica de Platão (na qual, as realidades ideais estão verdadeira e objetivamente além das físicas e estão "separadas" delas). Como vimos, o principal objetivo da alegoria é mostrar a diferença que existe entre filósofos e não filósofos e as razões da incompreensão recíproca. Para ressaltar bem essa diferença, Platão constrói uma imagem na qual as duas posiçōes são idealizadas ao extremo, representando a primeira como a dos prisioneiros em um mundo sombrio, privados de qualquer capacidade de movimento, e a segunda como a dos 
sábios que são capazes de conhecer perfeitamente as ideias e de transitarem à vontade entre os dois mundos.

Esse procedimento de exemplificação ideal é muito comum em Platão e não possui tanto o objetivo de demonstrar que a condição ideal realmente existe ou é realizável, quanto o de instituir uma regra válida para avaliar e classificar as situações intermediárias. No nosso caso, ao elucidar as diferenças existentes entre um perfeito sábio e um simples mortal privado de qualquer saber intelectual (o prisioneiro da caverna), Platão pretende mostrar que as mesmas diferenças valem, mesmo que proporcionalmente, cada vez que uma pessoa mais sábia (não importa quanto) seja colocada em confronto com outra menos sábia: caberá àquela mais sábia a função de educar e de governar, mesmo que seu saber não seja perfeito como o dos supostos filósofos de que fala a alegoria.

$\mathrm{O}$ que dissemos agora encontra correspondência em um passo do Fedro, inserido no grande discurso de Sócrates sobre o eros e sobre a condição da alma desencarnada. Sócrates afirma, como sabemos, que todo ser humano teve a possibilidade de contemplar as ideias antes do nascimento, e de trazer consigo alguma recordação delas para sua vida terrena. É claro que a qualidade dessas recordações variará de pessoa a pessoa; e, para Platão, os filósofos são justamente aqueles que possuem as recordações mais nítidas (250e-251a), não os que podem, quando serve, regressar ao mundo hiperurânio para revitalizar as recordaçôes. Além disso, exatamente como acontece n'A República, também 
no Fedro a distribuição das funções de educadores e educandos segue a divisão entre mais e menos sábios (entre quem recorda melhor e quem menos recorda), não entre o sábio perfeito e o perfeito ignorante.

Uma alusão a esse estado de coisas tem lugar também n'A República. Em um determinado momento, para esclarecer bem a natureza do filósofo, Sócrates contrapõe essa figura à do "filodoxo" (480a). É significativo que ele não tenha simplesmente oposto o filósofo, entendido como sábio, ao ignorante, mas, ao contrário, cunhou um estranho neologismo (justamente, "filodoxo"), que significa amante da opinião $($ doxa $)$. Faz isso justamente porque o filósofo não é o "sábio", mas aquele que ama a sabedoria; por isso o seu antagonista não pode ser o ignorante, mas, sim, alguém que ama também alguma coisa diferente do saber, que ama, como diz a palavra, a opinião (doxa).

A opinião, ou doxa, é uma noção que já encontramos algumas vezes, em diferentes contextos, neste livro. Com efeito, a doxa é, em Platão, um conceito bastante complexo. Em primeiro lugar, ele indica como doxa, justamente o resultado da metáfora da linha, ou seja, o conhecimento do sensível. Mas doxa é, também, como resulta do Banquete (202a) e d'A República (477a-478d), o grau cognitivo intermediário entre sabedoria plena (ou ciência) e ignorância absoluta. Isso vale particularmente quando a opinião é correta, isto é, quando corresponde à verdade. Nesse caso, a diferença entre opinião (reta) e conhecimento consiste principalmente no fato que, como já vimos (cap. 3, p. 
31), quem possui o conhecimento pode justificar seu saber, enquanto quem possui apenas a reta opinião, não. Como podemos deduzir sobretudo de algumas passagens do Teeteto (189e-190a) e do Sofista (264a), doxa pode indicar também a opinião de uma pessoa, como no caso em que se esteja de acordo com uma determinada tese: por exemplo, a opinião (doxa) de Trasímaco é que a justiça é o útil de quem está no poder.

Nesse último sentido, a noção de doxa não possui nenhuma relação particular com o conhecimento sensível; todavia, contém um detalhe de fraqueza que a separa da ciência: trata-se, de fato, de uma opinião sustentada por alguém, não de uma verdade constatada pela sua evidência. Então, nesse sentido, também o filósofo possui opiniōes. Porém, poderia parecer que o filósofo é justamente aquele capaz de tornar suas opiniōes infalíveis por meio dos raciocínios e, assim, elevar-se para além da reta opinião, até conseguir alcançar a ciência. Mas existe um problema. Qualquer raciocínio produzido pelo filósofo para sustentar suas opiniōes, também será submetido a uma opinião, na medida em que cabe sempre ao filósofo julgar se o raciocínio que produziu é verdadeiro ou falso; e esse juízo, novamente, será uma opinião.

Qual é o resultado de tudo isso? Que enquanto o saber tiver natureza proposicional - e como vimos, ao estudar a metáfora da linha, o saber do filósofo possui essa característica -, é impossível escapar totalmente da doxa. Assim, o filósofo não é quem possui um saber infalível, mas sim quem tem opiniōes mais fundamen- 
tadas do que outros, na medida em que é expert no uso da argumentação (isto é, da arte dialética, como Platão anuncia precisamente n'A República). Esse é o real motivo pelo qual Platão contrapóe o filósofo ao filodoxo. Visto que existe uma forma de doxa da qual nenhum homem pode se esquivar, a diferença que qualifica o filósofo não consiste no fato que ele possua um saber certo e infalível; essa diferença consiste no fato que o filósofo, ao contrário do filodoxo, se esforça constantemente por melhorar suas próprias opiniôes por meio dos raciocínios, porque o que ele deseja possuir não é a opinião, mas a ciência. Correlativamente, os homens não filósofos não são aqueles que não podem escapar das opiniōes (porque nem mesmo o filósofo escapa totalmente), mas aqueles que não desejam nada além, porque não acreditam de maneira alguma que existam coisas como o bem, o belo, o justo em si.

\section{O BEM}

Outra diferença importante entre a metáfora da linha e a alegoria da caverna consiste no fato que, nessa última, tem-se um elemento a mais, ou seja, a ideia do bem (representada através da imagem do sol). Esse princípio foi introduzido por Sócrates n'A República, pouco antes da exposição da metáfora da linha; aliás representa, em certo sentido, a ligação entre os temas ético-políticos, que ocupam os primeiros livros (I-V), e os epistemológico-metafísicos (V-VII). Como vi- 
mos, Sócrates sustentara que somente quem possui um verdadeiro saber tem capacidade para governar. Por sua vez, um bom governo tem a obrigação de gerar a boa vida, por isso, o que os governantes precisam conhecer, em primeiro lugar, é a natureza do bem. As constituições defeituosas, assim como a mentalidade comum, também dirigem seu trabalho para o bem, mas possuem um conhecimento muito reduzido dele: acredita-se, em geral, que existam coisas boas sem que por isso seja necessário a existência de um bem em si como medida absoluta, com base no qual as outras coisas são chamadas de boas (justas, úteis, etc.) [505a].

Para Platão, a existência de coisas boas implica a existência de uma hierarquia metafísica dos bens, cujo ponto mais alto é princípio que é só bem, a ideia do bem (ou bem em si, 504a-509b). A respeito disso, Sócrates se expressa de maneira vaga e reticente, admitindo poder dar a respeito somente sua própria opinião (506b-e). Assim, por enquanto, ele se livra do embaraço com uma metáfora: tal como o sol é o responsável pela vida e pela visibilidade da realidade material, a ideia do bem é aquilo que dá ser e cognoscibilidade aos objetos ideais. Essa imagem é logo enriquecida pela célebre afirmação segundo a qual a ideia do bem seria superior ao ser/essência (ousia) por dignidade e potência (509b).

Essa é uma tese enigmática, porque Sócrates considera a ideia do bem uma ideia como outras; portanto, deveria pertencer ao ser em sentido eminente, e não encontrar-se para além da essência. Poderíamos 
pensar que a ideia do bem é o resultado da aplicação à multiplicidade das ideias do mesmo procedimento aplicado à multiplicidade do sensível. A ideia do bem seria, então, a unidade das várias ideias, assim como a ideia de beleza seria a unidade das várias coisas belas.

Mas também esse esquema deve ser encarado com cautela. Se a ideia do bem é a unificação das várias ideias, por que Platão a chamou de ideia do bem? Não teria sido mais correto chamá-la de ideia da ideia? Ou, a partir do momento que representa a unidade suprema que reúne em si toda a multiplicidade, quer sensível, quer ideal, por que não chamá-la simplesmente de Uno? De fato, não se exclui que a ideia do bem d' $A$ República tenha algo em comum com o princípio de limitação (e, por conseguinte, com o de unidade) que é evidente tanto no Filebo (ver cap. 12, pp. 162-3) como nas doutrinas orais (ver cap. 14). Mas isso é possível porque Platão, como sabemos, acreditava que os conceitos de unidade, limite, proporção, etc. eram sinais eficazes para evidenciar a bondade das coisas: quanto mais una for uma coisa, isto é, quanto mais simples, orgânica e estruturada, mais alto é seu valor.

Se essas considerações são plausíveis, não é muito interessante tentar estabelecer se as ideias e a ideia do bem pertencem ou não a dois níveis ontológicos diferentes. Como vimos no capítulo anterior (pp. 71-4), colocando as ideias sob a égide do bem, Platão tem como objetivo revelar qual era a natureza dos princípios que ele procurava: as ideias não representam simplesmente a unidade lógica de uma multiplicidade, 
mas, também, e sobretudo, o sinal que a realidade se orienta tendo em vista o bem.

Essa conclusão é confirmada no livro VII, quando o filósofo trata das ciências. O papel privilegiado atribuído às matemáticas, interpretadas com sensibilidade pitagórica, tem precisamente o objetivo de preparar o acesso aos princípios entendidos como valores. Assim, em 526d-e, lemos que a aritmética e a geometria, se entendidas em sua natureza mais elevada e mais forte, poderiam facilitar a visão da ideia do bem. Deste modo, Platão pode aproximar, numa passagem em que se fala de astronomia, as coisas mais exatas (ou precisas) às coisas mais belas $(529 \mathrm{c}-\mathrm{d})$, como se a segunda característica derivasse da primeira. Também, a ascendência pitagórica particular desse tema é explicitamente documentada n'A República, onde Platão, não por acaso ao falar da música e da sua correspondência com a astronomia (lembramos a doutrina pitagórica da harmonia celeste), menciona os pitagóricos, com os quais também nós, diz Sócrates, "concordamos" (530d).

Um discurso idêntico, mas, obviamente, de nível mais elevado, deve-se fazer a respeito da dialética. Dialético, escreve Platão, não é somente quem é capaz de apreender a essência de todas as coisas, para assim prestar contas a si mesmo e aos outros, mas sobretudo quem conhece a essência do bem e é capaz de separá-la de todas as outras ideias, passando por todas as objeções e refutando-as não mediante opiniōes, mas segundo aquilo que é (534b-c). 
Essa passagem nos remete novamente ao problema de entender até que ponto a ideia do bem, para Platão, é realmente cognoscível. O Sócrates d'A República parece, a respeito disso, comportar-se de maneira ambígua. Por um lado, afirma que tal ideia é cognoscível (533a), e que deve ser particularmente conhecida pelos sábios que possuem o dever de governar o estado ideal; por outro, admite não dispor pessoalmente desse saber, mas apenas de opiniōes pessoais (506b-e, 517b, 533a).

Por outras palavras, o discurso de Sócrates parece hesitar entre os dois extremos: o da máxima certeza e o da máxima incerteza (tão grande que o leva a não pronunciar-se). Mas essa oscilação é compreensível. Platão deve afirmar a qualquer custo um certo conhecimento do bem, porque sobre esse pressuposto se fundamenta todo o seu projeto ético e político. Mas o esquema dos logoi, da opinião, compreendida como juízo da alma (ao qual Sócrates alude explicitamente), da necessidade de mediar o saber por uma dialética entendida como atividade dialógica e persuasiva que obriga a filosofia a ser um método sobressalente, obriga Sócrates a adiar qualquer explicação conclusiva e a admitir que o bem não possui as características da evidência e portanto não pode ser simplesmente alojado no discurso como se fosse um objeto. É justamente por isso que, no livro VII d'A República, Platão indica como requisito indispensável para poder amadurecer qualquer conhecimento longos anos de estágio e uma conversão aparentemente inatural de toda a alma (ver 525c). 
(Página deixada propositadamente em branco) 


\title{
A NATUREZA DO HOMEM:
}

\section{A ALMA}

\author{
O HOMEM É UM COMPOSTO DE ALMA \\ E CORPO. MAS É SOBRETUDO ALMA
}

\begin{abstract}
$\mathrm{Q}$ UAL É O LUGAR OCUPADO PELO SER HUMANO no esquema dualístico e metafísico que permeia a filosofia de Platão? A primeira coisa a dizer é que o homem é uma composição de alma e corpo. Essa definição era muito comum no modo ordinário de pensar dos gregos, desde os tempos de Homero, para o qual a alma (em grego psyche) representava a vida do corpo. Platão aceita, pelo menos de modo preliminar, essa distinção. No que diz respeito à alma, porém, ele aceita aquela que parece ter sido a posição do Sócrates histórico, o qual tinha substituído a imagem fisiológica tradicional (a alma é só e justamente aquilo que faz com que um corpo viva) por uma nova imagem espi-
\end{abstract}


ritualista: a alma é, antes de tudo, a sede do intelecto e da consciência e é o sujeito das ações e dos valores morais.

Platão não aceita inteiramente essa redução, mas conserva junto ao novo significado também o antigo, sobretudo porque dele tem necessidade para demonstrar que a alma é imortal. Mas é claro que para compreender a natureza do homem interessa a Platão que a alma seja entendida à maneira socrática. Quando Platão afirma que o homem é, sobretudo e essencialmente, a sua alma, estabelece uma continuidade com a posição de Sócrates. A superioridade da alma sobre o corpo é um tema constante na obra platônica desde os diálogos da juventude. Eis algumas referências indicativas.

$\mathrm{Na}$ Apologia, em um determinado momento, Sócrates explica que nunca poderia viver tranquilo e fora da esfera pública, e que enquanto viver continuará a analisar qualquer pessoa que encontrar através de seu método habitual: "você não se envergonha de, em vez de se preocupar com a inteligência, a verdade e em melhorar sua alma, se preocupar apenas com a acumulação de riquezas, glórias e honrarias?”. E se alguém disser que não é verdade, que se preocupa com a alma, Sócrates se empenhará em envergonhá-lo e refutá-lo, demonstrando-lhe que "faz pouco caso das coisas importantes e dá valor às coisas medíocres" (29d-30a). Obviamente que as coisas medíocres de que fala se referem à vida material, enquanto que as coisas mais importantes são os bens da alma.

Muito próximo do espírito da Apologia está o Alcibiades I (que consideramos autêntico). Os protagonistas são Sócrates e Alcibíades (o famoso e famigerado 
político ateniense), aqui representado como um jovem dotado de ótimos dotes materiais e intelectuais. $\mathrm{O}$ que ele mais quer na vida é ser um grande político, mas para isso, ou seja, para poder dar bons conselhos na assembleia, é necessário saber o que é o bem e o mal. Com essa finalidade é importante saber o que significa tornar-se melhor, isto é, cuidar de si mesmo (128e). Cuidar de algo não significa cuidar das coisas que pertencem àquela coisa, mas cuidar da coisa mesma (128d). Assim, se desejamos cuidar de nós mesmos, não devemos nos preocupar com aquilo que melhora algo que nos pertence, mas com aquilo que nos torna melhores (128e). Mas ainda: como podemos seguir esse objetivo se não sabemos, de acordo com o célebre dito de Delfos, quem somos nós (128e-129a)? É possível responder a essa pergunta assim que se perceber que o instrumento é diferente de quem o usa e que os homens se servem do corpo exatamente como de um instrumento (129b-e). Então, o corpo é uma coisa e o homem é outra, e essa outra coisa não pode senão ser a alma. (130c).

No Górgias, Sócrates, ao dialogar com Polo, estabelece como princípio que é melhor sofrer injustiça do que cometê-la, e que, uma vez cometida, é melhor sofrer a pena do que evitá-la. Para provar esse segundo ponto, Sócrates declara que a punição justa constitui um aperfeiçoamento da alma. De fato, a injustiça é o mal típico da alma e, entre todos os males, esse é o maior (477a-b). Mas é realmente conveniente para a alma liberar-se desse mal? Polo não pode negar que aquilo que é ruim é também aquilo que provoca dano 
ou dor; portanto, o mal da alma, sendo ruim, mesmo que não provoque dor, provoca sempre um dano. E é um dano gravíssimo, na medida em que "a mais terrível das situações é ter a alma em um estado ruim”, porque "essa situação supera todos os outros males, pelo dano enorme e pelo mal que comporta" (477d-e). Sócrates pode assim demonstrar a utilidade da punição. Mas aquilo que nos interessa neste momento é que para Platão existem dois gêneros diversos de males (477e): aqueles que dizem respeito ao corpo e à vida material (respectivamente, a doença e a miséria), e aqueles que dizem respeito à alma e à vida moral (isto é, a injustiça); e que o mal do segundo gênero é de longe o mais terrível de todos. Disso resulta, de novo, que a alma é o que verdadeiramente conta para o homem.

\section{A NATUREZA DA ALMA}

Dos trechos que vimos até o momento podemos extrair duas coisas: 1) o homem é essencialmente a sua alma, e 2) consequentemente, seus valores éticoespirituais, que dizem respeito precisamente à alma, são superiores aos materiais e corpóreos. $\mathrm{O}$ contexto dessas asserções parece adequado à imagem tradicional do Sócrates histórico, que aconselhava os homens a cuidarem de suas almas. Em suma, nos encontramos dentro de uma visão ético-pedagógica preocupada com a alma, naquilo em que o termo, modernamente, 
corresponde ao conceito de pessoa. Mas esta visão, traduzida na linguagem da filosofia platônica, enriquecese e amplia-se à luz de uma perspectiva que podemos chamar ontológica, inerente à natureza da alma, às suas relações com o corpo, à sua possível existência antes mesmo do nascimento e depois da morte do indivíduo. Essas determinações ulteriores não são acrescentadas por ser mais bela a completude, mas porque Platão as considerava necessárias ao seu objetivo de fundar sobre bases sólidas os temas "espiritualistas" da ética socrática que acabamos de mencionar.

Sobre a natureza da alma podemos extrair importantes informações sobretudo de alguns trechos do Fédon (65a-67b). Segundo Platão, a alma é o instrumento mediante o qual o homem pode compreender a realidade inteligível e imaterial; esse princípio é reforçado justamente pelo fato que esse objetivo só pode ser plenamente alcançado pela alma desencarnada. Essa relação íntima entre alma e mundo ideal tem efeitos significativos sobre a natureza da alma, que será, consequentemente, muito mais semelhante à realidade perfeita à qual aspira assemelhar-se do que ao mundo em que se encontra temporariamente ligada (80a-b); com esse mundo, a alma possui somente relações necessárias para garantir a existência material do homem, mas seus desejos mais profundos a levam mais além, a levam a se destacar do corpo para permanecer sozinha em si mesma (82d-83b). Pelo menos esta é a perspectiva descrita no Fédon, onde as tendências ascéticas do pensamento platônico são acentuadas ao máximo. 
A afinidade da alma com as ideias não a torna uma ideia. Ou melhor, exclui-o, exatamente porque Platão fala de afinidades. Se a alma fosse uma ideia, Platão não teria a necessidade de provar sua imortalidade, porque essa derivaria diretamente de sua natureza. A partir do momento em que a alma não é uma ideia, não nos resta pensar em outra coisa a não ser na existência de um ente intermediário entre o mundo sensível e o mundo ideal.

Com base no que dissemos, parece que essa mediação é totalmente desequilibrada e pende em direção ao segundo. Mas essa assimetria deve ser, pelo menos em parte, atenuada. Se do ponto de vista psicológico e humano, a alma é pensada nos moldes de um daimon órfico, preso em um corpo como se estivesse em uma prisão (Fédon 62b), mas, de um ponto de vista cósmico, deseja fugir - isto é, do ponto de vista da ordem da realidade que visa o ótimo - ela tem a tarefa "providencial" de dar vida aos corpos, como se lê no Fédon (105c-d), e também de dar vida a todo o universo, como explica o Timeu, onde Platão introduz sua teoria da alma do mundo com esta finalidade.

A alma não pode ser uma ideia também porque deve ser autonomamente capaz de adquirir os valores. Isto significa, para Platão, que ela deve possuir uma capacidade autônoma, livre de qualquer condicionamento. Tal exigência só é possível se a mesma for entendida como um sujeito independente do corpo. Mas a alma possui verdadeiramente esta independência? ou não é verdade que também as funçôes intelectivas (ou 
seja, o comportamento moral) dependem justamente do organismo físico?

Essa hipótese é uma das possíveis interpretaçōes da doutrina da alma-harmonia apresentada por Símias no Fédon (85e-86d). Se essa tese fosse verdadeira, ou seja, se a alma fosse a harmonia de um corpo mais ou menos como a música é a harmonia de uma lira, para Platão, as consequências seriam desastrosas. Pois se os comportamentos morais e intelectuais fossem inteiramente determinados pelo corpo, automaticamente deixaria de existir a liberdade de escolha, e ninguém mais seria condenado ou punido por suas açóes.

É impossível que a alma seja somente a harmonia do corpo: sabemos que a alma possui a capacidade de combater suas paixões e necessidades físicas, por exemplo, pode impedir o corpo de beber quando tem sede, ou pode acalmar e dominar a ira e até mesmo a dor. Essa possibilidade é suficiente para podermos afirmar que a alma é independente do corpo, porque, ao invés, ela seria obrigada a fazer todas as suas vontades, e os casos em que ela combate as paixões e as necessidades corpóreas não sucederiam (94b).

\section{DO FÉDON À REPÚBLICA E D'A REPÚBLICA AO TIMEU: A TRIPARTIÇÃO DA ALMA}

A imagem da alma que acabamos de resumir, presente nos diálogos do primeiro período até o Fédon, sofre a influência do chamado "intelectualismo socrá- 
tico": a alma representa sobretudo a razão do homem, enquanto todos os impulsos irracionais parecem ficar sob responsabilidade do corpo. Mas Platão sabia que uma representação excessivamente racionalista do ser humano não corresponde totalmente à realidade dos fatos. Por isso, desejando todavia manter o princípio pelo qual o homem coincide em essência com a sua alma, o filósofo será de qualquer maneira obrigado a descrever a natureza da alma de modo um pouco mais articulado. Além disso, Platão sabia muito bem que no homem muitas vezes os desejos e os instintos subjugam a razão, e se fosse verdade que tais desejos e instintos dependem unicamente de um fator independente da alma (isto é, o corpo), eles acabariam por ser dificilmente controláveis. Assim, Platão tem um interesse específico em aprofundar a natureza da alma, porque, se tais impulsos possuíssem uma raiz psicológica, uma correta educação da alma permitiria ao homem controlá-los e orientá-los.

Dessa fórmula teórica deriva a doutrina da tripartição da alma, que encontramos exposta, mesmo que de maneira diversa, n'A República, no Fedro e no Timeu.

É curioso notar que n'A República Platão utiliza, para demonstrar que existem na alma três diferentes funçôes, praticamente o mesmo argumento que tinha usado no Fédon para distinguir a alma do corpo. Posto que é impossível que o mesmo sujeito seja responsável por tendências contraditórias, então, a alma humana, na qual esta contrariedade é bem visível (às vezes acontece que se tem sede, mas a vontade de beber é 
bloqueada por um impulso oposto), deve ser composta de partes diferentes. Particularmente, evidencia-se na alma um elemento de caráter racional, que torna o homem capaz de elaborar raciocínios, e um impulso de caráter material (a chamada alma "concupiscível"), causador dos desejos físicos e corpóreos (438d-440a).

Junto a esses dois elementos coloca-se um terceiro, que se encontra em um ponto intermediário entre o primeiro e o segundo, denominado por Platão com uma palavra de difícil tradução (thymoeides), traduzida na maioria das vezes pelo adjetivo "animoso". Poderíamos chamar esse elemento de "força de ânimo" ou "força de vontade", mas, mesmo assim, não conseguimos cobrir todo o campo semântico do termo proposto por Platão. Geralmente, trata-se daquele impulso interior que nos empurra com força para uma coisa ou para outra, que não possui caráter racional, mas que também não pode ser reduzido a simples desejos físicos, até porque se pode pôr em conflito com eles. Esse elemento possui um caráter intermediário não apenas porque se encontra em meio aos outros dois, mas também porque pode se aliar com o racional ou com o concupiscente e, assim, arrastar toda a alma da esfera racional ou da dos desejos. Platão acredita, de toda forma, que por natureza a parte animosa é mais afim à parte racional e que sua aliança com aquela concupiscente deriva principalmente de uma péssima educação.

Esta tripartiçăo é substancialmente exposta no mito que Sócrates conta a seu amigo Fedro, no diá- 
logo homônimo. A alma pode ser comparada a uma espécie de carruagem alada, puxada por dois cavalos e guiada por um auriga (246a-b). O condutor representa claramente a parte racional da alma, os dois cavalos podem ser facilmente vistos como a parte concupiscente e a animosa. Enquanto um é arisco e tende constantemente a arrastar alma para baixo (ou seja, para o mundo dos desejos materiais e sensíveis), o outro é dócil e de boa raça, e se alia prevalentemente ao auriga (exatamente como a parte animosa da qual se fala n' $A$ República). Mesmo sendo dócil, nada impede que o segundo animal possa mover-se na direção contrária e arrastar toda a alma para baixo.

Também no Timeu é confirmada a tripartição proposta n'A República, mas acrescentando-se que somente a parte racional é verdadeiramente imortal (69c-71a). Todavia, destacamos o Timeu porque o dualismo entre "espírito" e matéria - já visivelmente enfraquecido com a tripartição presente n'A República e no Fedro - é ainda mais atenuado neste diálogo. O pequeno estranhamento entre alma e corpo é registrado, em primeiro lugar, pelo fato que Timeu localiza as três funções psíquicas em três diferentes partes do organismo (de cima para baixo: a cabeça, a parte do tronco que vai do pescoço ao diafragma, e a parte que vai do diafragma ao umbigo). Em segundo lugar, Platão demonstra conhecer a estreita relação que existe entre a alma e o corpo (87b): por meio de observaçôes de tipo "psicossomático", ele mostra o quanto as características do corpo são importantes para a saúde da 
alma e vice-versa (um princípio também interessante sob o ponto de vista dos resultados pedagógicos).

A tripartição da alma representa uma importante evolução em relação à doutrina exposta no Fédon. No entanto, não é necessário pensar que as visões de Platão tenham mudado de perspectiva. O Fédon é um diálogo onde o filósofo insiste sobretudo em demonstrar que a alma é imortal, e muito menos em esclarecer sua natureza. Quando ele passa a tratar diretamente desse tema, é compreensível que sua análise se faça muito mais complexa e articulada. O que importa ter em mente é o fato que tal complexidade não compromete decisivamente as escolhas morais do homem. Mas esse resultado pode ser alcançado mostrando que o homem poderá sempre (desde que faça com que sua alma seja governada pela razão), controlar e orientar os componentes irracionais e instintivos e direcionálos ao bem.

\section{A IMORTALIDADE DA ALMA}

Chegamos agora ao problema da imortalidade da alma. Aqui poderemos observar com certa clareza a separação das posições de Platão e Sócrates. Na Apologia, Sócrates declara o seu desconhecimento a respeito da morte: não sabe dizer se ela representa o fim de tudo ou se é uma dimensão ultraterrena (40c-d). No contexto eudemonístico em que se encontra a ética socrática, isso significa que a virtude não necessita de 
prêmio, porque é por si só suficiente para alcançar a felicidade. Que Platão considerasse essa posição inadequada pode ser visto primeiramente no Fédon, onde Sócrates se empenha em demonstrar a correspondência entre virtude e felicidade apelando aos destinos ultraterrenos.

A maior parte das demonstrações da imortalidade da alma se encontram no Fédon, mas podemos também encontrar uma n'A República e outra ainda no Fedro.

$\mathrm{Na}$ primeira prova exposta no Fédon, Platão demonstra que cada processo deve forçosamente possuir também o seu contrário, senão toda a realidade se reduziria, cedo ou tarde, a apenas um dos dois estados. Por exemplo, se ao sono não seguisse o despertar, inevitavelmente todos os seres vivos se encontrariam dormindo, o que, pela experiência, sabemos que não acontece. A mesma coisa vale também para o morrer e o renascer, caso contrário, chegaria o momento em que não existiria mais vida no mundo (70c-72e). Obviamente esse argumento pode no máximo ser útil para demonstrar a continuidade da vida, mas não para provar a imortalidade da alma individual. Para garantir um significado ético à imortalidade, que é o que interessava a Platão, é necessário supor a continuidade da consciência. É com esse objetivo que, no Fédon, é introduzido o argumento da reminiscência (ver cap. 6, pp. 63-5): é claro que a passagem da recordação de uma vida a outra pressupóe aquela imortalidade em sentido individual que Platão tinha em vista.

$\mathrm{O}$ terceiro argumento do Fédon se fundamenta na afinidade da alma com as ideias, com base na qual se 
pode supor que a alma seja qualitativamente diferente da realidade material e corruptível (78b-80b). Mas, como se vê pela objeção de Símias, esse argumento não é muito consistente (e Sócrates implicitamente o reconhece). A superioridade sob a perspectiva do valor nem sempre é garantia suficiente de uma diferença ou de uma superioridade ontológica. Por exemplo, as harmonias musicais produzidas por uma lira, do ponto de vista do valor, sem dúvida são superiores à madeira e às cordas de que é feito o instrumento, mas não por esse motivo serão mais duradouras do que ele; ou melhor, se o instrumento for danificado ou destruído, também a sua harmonia perecerá (85d-86d). Mesmo que a objeção de Símias seja refutável (como vimos), não danifica a verdade do princípio metodológico nela existente.

No Fédon, Sócrates tem a ocasiāo de propor um último e forte argumento ante a dúvida levantada por Cebes. Todo o discurso de Sócrates se baseava no fato de que a morte é a separação de alma e corpo, mas certamente a alma não sofre esta "morte". Mas poderia sofrer aquele tipo de morte que consiste na destruição da alma enquanto tal, do aniquilamento da sua possibilidade de estar separada mesmo na eventualidade de ela já ter sobrevivido a diversas encarnaçōes (86d-88b).

Para responder a Cebes, Sócrates apresenta uma premissa "metafísica" sobre a qual nos detivemos anteriormente, que vai da busca das causas da geração e da corrupção das coisas, passando pela autobiografia intelectual de Sócrates, até à obtenção da dimensão das ideias (95e-100a). Uma vez estabelecida a existência 
das ideias, pode-se demonstrar também a existência dos objetos aos quais uma ideia é conatural, ou característica essencial, isto é, aquela característica que os objetos não podem perder. Por exemplo, o fogo é sempre quente, a neve é sempre fria, etc. Em outras palavras, existe uma diferença entre o calor do fogo e o calor de uma peça de metal, esquentada por uma causa exterior: somente o fogo é intrinsecamente quente, enquanto o metal pode possuir ambas as qualidades em tempos diferentes. A mesma relação existente entre o fogo e a ideia de calor ocorre entre a alma e a ideia de vida, razão pela qual a alma não pode perder aquela característica e, portanto, nunca se poderá dizer que morreu. Demonstra-se que a alma é imortal pelo mesmo princípio que o fogo jamais poderá ser "resfriado". Sendo assim, quando a morte se aproximar, a alma ou sairá intacta ou terminará por ser destruída (como o fogo quando apagado com água). Platão conclui, usando uma estratégia retórica que na realidade assume sem demonstraçóes a passagem decisiva do argumento, que aquilo que foi definido imortal, certamente seguirá a primeira opção, ou seja, quando a morte se aproximar, sairá intacto. Logo, a alma é imortal e indestrutível (100a-106d).

A demonstração que aparece no Fedro (245c-246a) é breve e contundente (e, no seu conjunto, muito bem construída). Aquilo que se move sempre é imortal; por outro lado, move-se sempre apenas aquele ente capaz de mover-se por si mesmo, que é causa do movimento nos outros entes e não está sujeito à geração nem à cor- 
rupção. A existência de um ente desse tipo é provada pelo fato que, se não existisse uma razão última de todos os movimentos, capaz de gerar o movimento por si mesma, cedo ou tarde, tudo se tornaria imóvel. Tal princípio não pode ser a matéria, porque ela recebe o movimento do exterior; de fato, somente os seres animados (isto é, dotados de alma) possuem movimento espontâneo, não atribuído por outrem. Com isso se demonstra que a alma constitui o princípio eterno do movimento - necessária dada a consideração geral do princípio de movimento - e, por isso, é imortal.

Muito mais fraca é a prova exposta n'A República (608d-610a), fundada somente sobre uma simples analogia. Assim como o mal do corpo é a doença, o mal da alma é o vício moral. Mas enquanto a doença leva o corpo à morte, o vício moral não consegue fazer o mesmo com a alma. Demonstrando-se que, se é verdade que a vida da alma não pode ser contaminada pelo seu próprio mal, não existirá um mal capaz de destruí-la e, por conseguinte, ela será imortal.

Que valor têm estas demonstraçôes? Observemos, em primeiro lugar, que os interlocutores de Sócrates admitem sem hesitação que a alma existe como uma coisa diferente do corpo e que a morte é a separação entre essas duas entidades. É claro que tais premissas não podem ser consideradas válidas de modo geral e que, por isso, as demonstraçóes platônicas possuem um raio de ação delimitado desde o início. Se olharmos bem, somente a afirmação de que alma e corpo são duas coisas diferentes já seria por si só capaz de 
evocar um "sistema espiritualista", ao qual as concretas demonstrações não acrescentam nada de verdadeiramente decisivo.

Além disso, Platão sabia que seus argumentos eram muito mais persuasivos do que demonstrativos. No final da parte argumentativa do Fédon, depois de ser desenvolvida a demonstração mais complexa e incisiva da imortalidade da alma, Sócrates aprova a postura ainda parcialmente duvidosa de Símias, e o incentiva a continuar a pesquisa (107b). Nesse caso, Platão parece querer dizer que a pesquisa nunca terminará, e que seria inútil procurar o argumento e a palavra capaz de pôr termo a qualquer discussão. Como diz Símias, em outro trecho do Fédon (85c-d), a respeito de questôes tão difíceis como a imortalidade da alma, é praticamente impossível chegar a conclusóes certas. Por isso, é necessário contentar-se com o melhor e o menos refutável dos raciocínios (logoi) humanos e usá-lo como se fosse uma jangada para atravessar, assumindo todos os riscos, "o grande mar da vida”. Platão, sem dúvida, estava convencido de que o homem não dispunha de um guia melhor para compreender a realidade e organizar sua vida, que o exercício do logos; mas estava longe de admitir que esse instrumento fosse infalível ou onipotente. 


\title{
O AMOR PLATÔNICO \\ E A EDUCAÇÃO DA ALMA
}

\author{
EROS, DESEJO E FILOSOFIA
}

\begin{abstract}
T igado ao tema da alma, e por diversos modos Crucial, quer na antropologia de Platão, quer de maneira geral em toda a sua filosofia, está a célebre questão do eros (amor), que se costuma indicar com a expressão "amor platônico". Geralmente, essa expressão quer somente dizer um amor puramente ideal, que nada tem a ver com o plano físico. Trata-se, sem dúvida, de um aspecto importante do eros, tal como o pensava Platão. Mas, do ponto de vista filosófico, não é o mais importante. $\mathrm{O}$ conceito de eros, não somente para Platão, revela um dado essencial da natureza humana, ou seja, a sua tensão dinâmica para a obtenção de um determinado objetivo. Em outras palavras, essa vontade pode ser chamada de "tensão" ou "desejo".
\end{abstract}


É fácil constatar que esse elemento é realmente essencial na vida de todos os seres humanos (e não só deles). A vida é movimento, dinamismo, tensão para e desejo de algo: particularmente tensão para a obtenção das coisas que parecem apetitosas e boas ao sujeito que as deseja. No caso do sujeito racional, certamente ele aplicará sua inteligência e seu discernimento para conseguir alcançar certos objetivos que valham realmente a pena. Nesse sentido, para Platão, o eros se liga intimamente à filosofia, porque o desejo que acomete a todos, de viver uma vida boa, nunca poderá ser realizado se pelo menos não tentarmos conhecer o bem: em outras palavras, não poderá ser realizado se não dispusermos nossas vidas em direção do conhecimento. O resultado disso tudo é que o eros representa o nosso estímulo decisivo para a prática da filosofia. O tema do amor é tratado por Platão sobretudo no Banquete e no Fedro.

\section{O BANQUETE: OS PRIMEIROS CINCO DISCURSOS SOBRE O EROS}

O Banquete narra uma reunião social na residência do poeta Agatão, por ocasião da comemoração da sua vitória em um concurso teatral. Os convivas decidem, ao final do jantar, pronunciar, um de cada vez, um discurso em louvor de Eros. O primeiro a se pronunciar é Fedro (o mesmo do diálogo homônimo); o segundo é o orador e advogado Pausânias; o médico Erixímaco é o terceiro; o quarto é o poeta Aristófanes; logo 
em seguida, fala o anfitrião Agatão; e Sócrates, com seu discurso, fecha o encontro. Todas as personagens compóem seus discursos nos moldes de suas respectivas profissões.

Dos discursos anteriores ao de Sócrates, é célebre o de Aristófanes. Ele conta que os homens eram, no início, seres monstruosos e potentes, que possuíam duas cabeças, quatro pernas e quatro braços, etc., e eram de três gêneros sexuais (homem-homem, mulher-mulher e homem-mulher). A sua força e soberba eram tais que chegavam a ameaçar até mesmo os deuses, razão pela qual Zeus, por precaução, decidiu dividi-los em dois. Uma vez divididos, homens e mulheres passaram a se buscar para se unirem novamente e, quando se reencontravam, deixavam-se morrer abraçados. Então Zeus quis doar aos homens a procriação através da copulação, da qual até aquele momento eram privados. Assim, homens e mulheres podiam praticar a união, para fins procreativos ou somente para relaxarem das incumbências da vida. Eis a explicação do motivo pelo qual homens e mulheres possuem aquele sentimento amoroso de busca pela sua outra "metade" (189c-194c).

Depois da intervenção de Agatão (tão lírica que arrancou até mesmo um caloroso aplauso dos convivas), chega a vez de Sócrates. Ele, antes de tudo, com evidente ironia, aprecia a fina e estilística oratória de todos aqueles que o precederam. Mas, em seguida, profere uma contundente crítica: se realmente se quer louvar alguém, é necessário que se diga sempre e somente a verdade, não se devem contar falsidades somente para bajulá-lo. Talvez porque partiam do 
pressuposto tradicional que Eros era um deus, todos os oradores se sentiram na obrigação de demonstrar que o amor é uma coisa boa. Mas, depois de um breve diálogo com Agatão, Sócrates demonstra que não é assim, ou seja, que o amor não pode ser bom. De fato, amor é desejo de beleza e bondade (estes conceitos são quase assimilados) e desejamos somente aquilo que não temos. $\mathrm{O}$ amor enquanto tal esgota-se na força de atração que empurra uma coisa para outra: a beleza e a bondade de amor não são derivadas do amor enquanto tal, mas daquilo que o amor deseja (199c-201c).

\section{O DISCURSO DE SÓCRATES}

Terminado esse preâmbulo, Sócrates inicia a sua verdadeira participação, dizendo que foi iniciado nas coisas do amor, quando ainda era inexperiente e submisso aos preconceitos, por uma mítica mulher da cidade de Mantineia, de nome Diotima. Ela lhe explicou, como ele mesmo tinha dito a Agatão, que Eros não era belo e nem bom, mas nem por isso se devia dizer também que ele fosse feio e ruim. Para ilustrar esse ponto, Sócrates compara o eros ao nível cognitivo da reta opinião (ver cap. 3, p. 31 e cap. 7, PP. 82-3): como a reta opinião representa o grau intermediário entre a ignorância e a sabedoria (202a), existirá também entre o belo e o feio um grau intermediário do que não é belo e nem feio. Eros está nesse grau intermediário, por isso, não pode ser denominado deus 
nem imortal. Eros, de fato, é um ser intermediário entre homem e deus, entre mortal e imortal, ou seja, de acordo com a terminologia tradicional da religião grega, é um demônio (daimon).

Com base nessa definição, Diotima constrói uma genealogia alegórica de Eros. Seu pai é Poros (Expediente), que, por sua vez, é filho de Métis (Prudência). Eros herdou do pai todas suas características boas e belas. Sua mãe é Pénia (Pobreza ou Privação): dela vêm suas qualidades negativas. Assim se explica a natureza intermediária do amor. Do pai, Eros recebe a capacidade e o desejo de buscar as coisas boas e belas; da Pobreza, sua mãe, deseja buscar justamente aquilo que não possui. Só quem não possui aquilo que deseja está na condição de desejar, quer porque não é tão rico para o ter já, quer porque não é tão pobre ou se encontre privados de expedientes para o desejar. A partir do momento em que a sabedoria (sophia) é uma das coisas mais belas que existem, desse ponto de vista, o amor se encontra na metade, entre a sabedoria e a ignorância, logo, é filo-sofo (204b): ou seja, não é sábio (sophós) nem totalmente ignorante, porque é um amante (philos) da sabedoria.

O breve diálogo de Sócrates com Agatão e, sobretudo, a primeira parte do discurso de Diotima, deslocaram o núcleo temático da investigação da bondade do amor para o único fator que pode tornar as coisas boas (inclusive o amor), ou seja, o bem. O eros é qualificado como o desejo das coisas que são em si e por si belas e boas (204d). Mais precisamente, o amor consiste no desejo de possuir essas coisas, porque 
possuindo-as, o homem será feliz (205a). É instituída uma ligação entre aquele tipo de desejo que é eros e o desejo da felicidade que, no Eutidemo, fora declarado comum a todos os homens (278e, 282a). Esta ligação legitima Platão a conferir máxima generalização ao seu discurso. Seria difícil admitir que todos os homens estão sempre "enamorados", no sentido estritamente psicológico do termo (205a-b). Mas se eros é entendido de maneira abrangente como o desejo de possuir o que é bom, então, sua universalidade será garantida. Nesse sentido, todos os homens estão enamorados, porque todos desejam ser felizes, e a felicidade consiste justamente em possuir o que é bom.

O que ainda resta estabelecer é em que consiste o bem para o qual o homem tende e quais são as etapas que o levam a alcançá-lo, mas sobre esse ponto parece surgir algumas dificuldades. De fato, o discurso é como se desdobrasse, movendo-se na direção de dois objetivos diferentes, entre os quais, nem sempre há uma clara congruência: de um lado, o escopo do eros é alcançar a posse do bem enquanto tal; e, do outro, é extrair do eros bons frutos, diferentes dos do bem em si, que tenham efeitos positivos nas nossas vidas éticas, políticas e de relação com o próximo.

Diotima denomina esse segundo objetivo, "procriar no belo" com alma, em analogia com a procriação através do corpo. Assim como o desejo de procriar filhos é movido pelo impulso de imortalidade, também o desejo de procriar com a alma é estimulado pelo impulso que os homens possuem de se eternizarem através de suas obras (206b-207a). 
Diferentemente do que acontece em outros diálogos, no Banquete, não são previstas outras formas de imortalidade. Provavelmente isso se deve em parte ao contexto, que mostra Sócrates em companhia não de seus fiéis discípulos (como no Fédon), mas de alguns importantes expoentes da cultura tradicional, dos quais, poucos acreditavam na ideia de imortalidade individual. Mas isso não significa que Platão, quando escreveu o Banquete, tivesse abandonado essa teoria (de fato, ela retorna em outros diálogos como o Fedro, o Timeu, e as Leis).

O fruto da procriação no belo através da alma pode assumir diferentes figuras. Os verdadeiros amantes deverão gerar discursos sobre a virtude e indicações éticas de como se deve ser e de como se deve comportar um homem verdadeiramente bom. De maior estima ainda serão os filhos destes homens, frutos do puro amor pelo saber e pelo bem; tais são os filhos de Licurgo e de Sólon, isto é, as leis que eles deixaram para suas respectivas cidades, Esparta e Atenas, e que com justiça os cobrem de glória imortal (209d-e). Segundo esta perspectiva, o amor do bem representado pelo eros é expansivo, não se esgota na mera posse, mas permeia toda vida política e civil, transformandose em um benefício para todos os homens.

Mas, junto a essa visão, que nos projeta para baixo, existe outra via que nos leva para cima, que se satisfaz somente quando o cume do conhecimento for alcançado. Para percorrer esse caminho, é preciso cumprir quatro estágios; 1) amar os corpos belos; 2) convencer-se de que em todos os corpos a beleza é sempre a 
mesma, por isso, devemos abandonar o amor somente por um indivíduo; 3) convencer-se de que a beleza da alma é superior à beleza do corpo; 4) ter a capacidade de enxergar a beleza nas obras humanas e nos objetos intelectuais, até compreendermos que a beleza é sempre igual a si mesma. Depois de superar esse estágio, o enamorado será finalmente capacitado a conhecer a beleza enquanto tal, que Diotima desenha com traços característicos da ideia platônica: uma beleza que "não nasce nem perece, não cresce nem diminui, não é bela em certos casos e nem feia em outros, não é às vezes bela e outras vezes feia, como se fosse bela para uns e feia para outros. Essa beleza não se manifestará através de um objeto, nem mesmo em nenhuma parte integrante do corpo como em um rosto ou em uma mão, nem em alguns discursos ou em algumas ciências, em nada diferente dela mesma, como por exemplo, em algum animal que vive na terra ou no céu, ou em qualquer outro lugar; deverá se assemelhar sempre a ela mesma, sendo sempre da mesma forma, enquanto tudo o que é belo participa dela de tal maneira que, embora nasça e morra, ela não diminuirá nem crescerá, permanecerá imune a todo o devir" (210e-211b).

No Banquete, nada se diz a respeito da condição da alma após a morte, o que parece prometer ao homem um percurso cognitivo que o levaria a alcançar o mais pleno e perfeito conhecimento das ideias já nesta vida. Mas, na realidade, existem muitos elementos que contrastam com essa hipótese.

O discurso de Sócrates/Diotima, em primeiro lugar, seria marcado por uma grave contradição, a partir 
do momento que na sua primeira parte foi evidenciada a distância do saber filosófico do divino e sua afinidade com a reta opinião. Em segundo lugar, o silêncio sobre a imortalidade da alma não nos permite estabelecer se o cume da escala do amor pode realmente ser alcançado na vida terrena ou (como vemos no Fédon) na ultraterrena. Enfim, quando Diotima inicia a descrição dos vários passos da scala amoris, ela, adverte Sócrates, de que até aquele grau, ou seja, até ao tema "político" da geração no belo, ele podia ser iniciado, mas em respeito às últimas coisas e à visão final (a linguagem é a das iniciações mistéricas), ela não sabe se ele será capaz de a seguir (210a). Como sabemos, Sócrates, nos diálogos platônicos, geralmente representa o modelo exemplar do filósofo; com isso Platão provavelmente deseja dizer que o homem enquanto tal nunca será capaz de ter uma visão perfeita das ideias: enquanto for mortal, o homem pode, no máximo, ser um filósofo (como Sócrates), ou seja, poderá somente amar a sabedoria, mas permanecerá excluído do conhecimento dos mais elevados mistérios (a visão mais pura e direta das ideias).

Se essa interpretação é justa, podemos reconsiderar de um ponto de vista mais abrangente todo o problema dos frutos do eros. A contemplação da ideia é, sem dúvida, funcional para a procriação no belo (212a), ou seja, para a ação ético-política, porque sem um conhecimento preventivo daquilo que é bom, o bem não poderá ser realizado. Assim que a visão da ideia for alcançada, não é talvez inevitável que o filósofo (isto é, o amante da sabedoria) pare nessa condição e não sinta 
mais a necessidade de se preocupar com a vida prática? A ação ético-política não desviará talvez a filosofia do seu verdadeiro escopo (ou seja, o conhecimento)? Usando termos que depois serão comuns à cultura medieval: a vita activa e a vita contemplativa não são talvez dois objetivos antitéticos?

Esses problemas seriam certamente insolúveis se Platão acreditasse de verdade que o homem, na sua condição de mortal, pudesse ter à sua disposição a visão das ideias. Mas sabemos que as coisas não são assim. Portanto, o retrocesso da atividade do filósofo no ato de gerar no belo, isto é, no mundo da ética e da política, não possui caráter dispersivo, terminará por representar a atividade mais elevada que o homem tem à sua disposição. $\mathrm{O}$ problema agora se transforma muito mais em mostrar que o homem, mesmo que não possa atingir o último grau da iniciação aos mistérios, possui um conhecimento do belo pelo menos suficiente para governar sua atividade reprodutiva. Esse ponto virá proposto novamente n'A República e no Filebo.

\section{O AMOR NO FEDRO}

O Fedro inicia com o encontro, fora dos muros de Atenas, de Fedro com Sócrates. Fedro, grande apaixonado pela retórica, traz consigo um discurso que acabou de ouvir, composto pelo grande logógrafo (autor de discursos ou aquele que escrevia para terceiros, precisamente para fins judiciários) Lísias, no qual se 
procurava demonstrar que é mais conveniente para um jovem se entregar a quem não o ama do que a quem o ama. Entusiasmado com o que havia ouvido, Fedro relê o texto a Sócrates. Inicialmente, Sócrates se diverte, e a título de competição, desafiando Lísias compõe outro discurso sobre o mesmo tema (237b241d), mas, logo em seguida, arrepende-se do que fez (porque falou mal de Eros, que é um deus), e elabora um segundo discurso, de teor bem diferente, desmentindo seu primeiro discurso.

Em seu primeiro discurso, Sócrates tinha sustentado que não se pode falar bem de um assunto, sobretudo, tratando-se de questôes difíceis de chegar a um acordo, se não se tem pelo menos uma definição daquilo que se discute. Por isso, Sócrates, antes de tudo, se empenhou em elaborar uma definição de amor: eros é um desejo particularmente forte, estimulado pela visão da beleza e propenso à realização dos prazeres físicos (238b-c). Para quem conhece o Banquete, não é difícil perceber que, se este é o escopo do amor, a opinião que se faz dele só poderá ser negativa. Se, em vez disso, se entender que eros é bom (por ser divino), certamente a definição agora proposta é errada. Isso pareceria uma referência a um discurso similar àquele desenvolvido no Banquete, no qual foi realizada uma purificação do amor no sentido racional e espiritual. Mas, como agora veremos, no Fedro, Platão introduz significativas variações.

Sócrates não nega que o amor seja uma forma de loucura; nega, em vez disso, que a loucura seja sempre 
um mal. De fato, existem formas de loucura, boas e benéficas, como a poesia, a profecia e até mesmo o próprio amor (244a-245a). Este motivo está ausente no Banquete e marca a diferença principal entre as teorias sobre Eros expostas nos dois diálogos. No Fedro, mesmo confirmando a universalidade do sentimento amoroso já estabelecida no Banquete, Platão tem o interesse de mostrar que, para alcançar a estrada que conduz à filosofia, é necessário um salto, uma difícil e delicada passagem para uma dimensão diferente, que não conseguiremos alcançar se não formos inflamados por um violento desejo, justamente como aquele que anima as loucuras de amor.

Tudo isso se torna bem claro se relevarmos, como já sabemos, que, no seu segundo discurso, Sócrates indica a doutrina da reminiscência. Às margens desse tema, ele observa que "trazer à tona recordações de coisas ultraterrenas estando em uma realidade terrena não é tarefa fácil para todas as almas" (250a). Esse processo é, de fato, particularmente artificial, porque distancia o homem do que parece ser o seu próprio mundo. O problema é da educação, ou seja, do caminho intelectual e moral que o homem deve cumprir para se convencer da excelência da filosofia e da superioridade dos bens espirituais em relação aos materiais. $\mathrm{O}$ eros intervém justamente para corrigir a aparente artificialidade da conversão do homem para a filosofia, que o mesmo Platão havia evidenciado em alguns textos, como no Fédon e no Teeteto.

De que maneira eros consegue realizar essa tarefa? Platão sai do impasse com uma imagem que, mesmo 
tendo um inconfundível sabor mítico, contém uma inegável verdade psicológica e filosófica impossível de negar. $\mathrm{O}$ único resquício de ideia conservado na realidade sensível é o da beleza, ou seja, é a única que conseguimos ver: porque a beleza é a imagem humana que mais se aproxima da perfeição da ideia (250c-e). E, além do mais, para usar uma expressão particularmente apropriada, diante da beleza, o homem se sente como que transportado para um outro mundo, melhor do que aquele em que se encontra; inconscientemente, ele suspeita que aquilo que o toca provenha de uma dimensão mais elevada, e que, naquela beleza, se esconda um bem puro, não contaminado pelas interferências e pelos problemas que cotidianamente fazem parte da vida do homem. A experiência da beleza oferece um ponto intermediário entre ideal e real, porque representa a manifestação de algo humano que se mostra no mundo, que é feito de matéria, mas que também é divino, espiritual e superior ao homem.

Sob esse aspecto, a filosofia de Platão é marcada por uma sutil ambiguidade. Por um lado, ele gostaria, como veremos quando analisarmos $A$ República, que a educação para a filosofia fosse um percurso linear, planificado tecnicamente com um curriculum normal de disciplinas. Por outro, ele apercebe-se que essa tranquila tecnicidade é um objetivo irrealizável, porque o percurso educativo depende também de princípios invisíveis, que não podem ser exibidos como objetos ou teoremas; por isso, a educação para a filosofia deve se contentar em permanecer sempre numa situação contínua de altos e baixos, não alheias a possíveis recaídas, 
porque ela necessita da energia que só a pura razão, ligada às limitações da condição mundana, não pode dar.

A diferença entre o Banquete e o Fedro é marcada pelo fato que, neste último diálogo, está presente a perspectiva ultraterrena. Para conseguirmos nos elevar da realidade terrestre, precisamos de um instrumento muito potente. E não se trata de uma comparação arriscada porque Platão usa para tal a metáfora das asas. A vida mortal inicia-se quando a alma perde suas asas e cai na terra. Mas, mesmo na sua vida terrena, se bem educado, o homem pode recuperar pelo menos uma parcela da realidade ideal que viu. O eros representa justamente uma dessas formas de educação. Instigado pela visão da beleza, pouco a pouco, o ser humano recupera suas asas $(249 \mathrm{e})$, embora nem sempre elas o habilitem a levantar voo. Dá-se o caso que o desejo busque uma elevação, da beleza e do prazer físico à beleza da ideia e aos prazeres que ela dá.

O tema da ascensão liga outra vez o Fedro ao Banquete. Mas somente de maneira breve, porque a scala amoris não possui no Fedro a mesma estrutura ordenada. Neste caso, Platão se concentra sobretudo em mostrar a complexa fenomenologia do sentimento amoroso, o ambíguo material, constantemente irresoluto, feito de impulsos elevados e de desejos sensíveis (o cavalo bom e o mau, ver cap. 8, p. 92). Além do mais, Platão no Fedro, dedica um lugar de relevo também ao amante, que nem sempre consegue permanecer à altura do seu amor (256c-e), ou seja, ao filósofo que permanece sempre demasiado "amante" (philos), mas um pouco menos "sábio" (sophos). Em 
suma, neste diálogo, Platão parece olhar com mais tolerância para a viscosidade da experiência humana, parece plenamente consciente do fato que, na vida do homem, seja qual for seu esforço, ele sempre terá uma grande tendência à impuridade.

\section{A PSICAGOGIA NO FEDRO \\ E A DESVALORIZAÇÃO DA ESCRITA}

$\mathrm{O}$ eros não é o único assunto tratado no Fedro. $\mathrm{O}$ segundo grande assunto é a retórica; o diálogo se conclui com algumas enigmáticas páginas, onde Platão desvaloriza o discurso escrito e exalta a comunicação oral. Agora nos ocuparemos desses temas, porque se encontram em plena harmonia com a doutrina do eros e, além do mais, constituem um importante aprofundamento do seu significado filosófico.

A "psicagogia", ou seja, ou a condução das almas, é o tema central para onde convergem as várias partes do Fedro. O caminho que as almas devem percorrer indica, para Platão, as possibilidades que os homens têm para alcançar o conhecimento; é o percurso mediante o qual nos tornamos filósofos. Também dissemos que, em Platão, esse percurso assume duas diferentes tipologias, que se entrelaçam de formas diversas: a vida metódica e técnica, fundada no conhecimento, ou, na concepção "apolínea" do eros presente no Banquete; a vida errante, fundada em iluminaçóes repentinas, ou, na concepção "dionisíaca" do eros da qual se fala no Fedro. O contraste entre oralidade e escrita é outro 
modo escolhido por Platão para descrever e ilustrar a psicagogia desse segundo gênero.

A segunda parte do diálogo é constituída por uma tentativa de responder à pergunta sobre como devem ser compostos os discursos para serem belos (258d), de acordo com o habitual senso ético de Platão: isto é, como devem ser os discursos para serem de verdade psicagógicos, para conduzirem as almas ao bem. Para responder a essa pergunta, Sócrates elimina, antes de tudo, os discursos que não são perfeitamente psicagógicos. São os discursos dos retóricos e dos políticos (também dos poetas, sofistas, etc.), que não possuem a intenção de conduzir quem os escuta ao bem, mas somente fazer com que quem os escute faça aquilo que seus autores ou comitentes desejam (259d-260d).

Assente que somente a filosofia pode conduzir a alma ao bem, esse caminho pode ser executado mecanicamente através de uma metódica aprendizagem, por um curso de estudos ou através da leitura de determinados textos? Assim seria se a filosofia não representasse qualitativamente uma passagem do mundo sensível ao mundo ideal. Mas é justamente essa separação que faz com que o problema da psicagogia e da educação, isto é, o problema da formação em moldes filosóficos da sociedade ético-política, seja particularmente espinhoso.

A ideia principal, repetida quer no Banquete, quer no Fedro (278d), é que os homens podem, na melhor das hipóteses, ser amantes do saber (isto é, philosophoi), e não verdadeira e completamente sábios (sophoi); sábios são somente os deuses. A particularida- 
de do eros enfatiza justamente essa dificuldade e, ao mesmo tempo, tenta superá-la. O escopo final é fazer com que o homem, mesmo não tendo mais aquele conhecimento das ideias que possuía quando sua alma ainda vivia no hiperurânio, possa, todavia, recuperar alguns resquícios da verdade que uma vez presenciou.

Essa recuperação é também o objetivo dos discursos filosóficos (logoi). Sua tarefa é suprir a falta de uma verdadeira intuição intelectual, estimulando na alma um exercício dialético que eternamente se move do uno ao múltiplo e vice-versa (265c-266c), até o ponto em que a alma se convença de que a multiplicidade pressupõe a unidade e que as açôes e o conhecimento humanos pressuponham uma perfeita dimensão ultraterrena. Desta maneira, a filosofia se dirige para a persuasão e, nesse sentido, funde-se com o eros. $\mathrm{O}$ eros e a persuasão desempenham a idêntica tarefa de preencher o hiato que separa o homem de um conhecimento racional totalmente transparente e completo.

Com base no que foi dito, se explica também a desvalorização da escrita. Um texto escrito se torna válido na medida em que se refere a um saber presente alhures, ou seja, na alma (278a). Portanto, o discurso filosófico, que não por acaso Platão articula sempre em forma de diálogo, não possui a tarefa imitativa de refletir a verdade, mas "erótica" e psicagógica de instigar na alma a persuasão, mediante a exercitação dialética. Nesse sentido, e somente nele, a comunicação oral é superior à escrita, já que o texto escrito, enquanto imóvel e imodificável, é incapaz de dialogar e de responder (275d-e). Portanto, de um lado, a sua 
capacidade de estímulo à persuasão é bastante reduzida com relação à comunicação oral e verdadeiramente dialógica; e, do outro, é muito enganadora, porque se apresenta como uma contrafação dissimulada da estabilidade e do aspecto conclusivo da ciência, que, pelo contrário, é unicamente característica da visão intelectual das ideias (e, logo, não pode figurar em nenhum tipo de "texto", nem escrito nem oral).

Platão é consciente quer do fato que a filosofia, junto com as recaídas práticas que a caracterizam, pode se fundar somente no conhecimento da verdade, quer do fato que essa verdade, de alguma maneira, é alhures e não é imediata nem completamente disponível ao homem. Por isso, na noção platônica de filosofia, mesmo que o lugar central seja ocupado por aquela verdade que se deseja descobrir, assumem uma função importante a condição da alma, a qualidade de seus desejos e a tendenciosidade das suas convicções. 


\title{
CAPÍTULO X \\ A ÉTICA E A POLÍTICA \\ N'A REPÚBLICA
}

\section{ÉTICA E POLÍTICA EM PLATÃO}

\begin{abstract}
É
CARACTERÍstico do Pensamento antigo, pelo menos no que diz respeito à época clássica, que não exista uma nítida distinção entre ética e política. Isto se deve a diversos fatores, mas os principais são provavelmente os seguintes. Em primeiro lugar, de acordo com a particular estrutura política em que o mundo grego estava articulado (ou seja, o sistema das poleis), o cidadão vivia imerso na sua própria comunidade, da qual era parte integrante e muitas vezes ativamente participador (particularmente nos estados, como Atenas, regidos por longos períodos pelo regime democrático). Nessa situação, era bem compreensível que os comportamentos privados assumissem uma valência pública e que, inversamente, o mundo da
\end{abstract}


política influísse de maneira direta nas normas éticas. Em segundo lugar, a mesma distinção entre público e privado, entre a esfera das relações familiares e sociais e a das relações com as instituçôes, era muito mais sutil do que no mundo moderno. Enfim, os pensadores políticos da época clássica, pelo menos até Aristóteles, não consideravam a política como uma atividade técnica dotada de mecanismos e de regras próprias, mas principalmente como a mais alta e completa forma de educação.

Esse panorama referencial é totalmente evidente em Platão. Se pensarmos, por exemplo, na aparente ambiguidade da figura de Sócrates, a quem Platão faz dizer, por um lado, que nunca se ocupou de política (Apologia 31c-32a) e, por outro, que era o único homem verdadeiramente político do seu tempo (Górgias 521d): este juízo depende do fato que Sócrates era o único, entre todos os pretensos sábios que dominavam a cena pública de Atenas, a preocupar-se seriamente com a educação dos seus concidadãos. Assim, como já dissemos, o nexo entre política e educação é muito estreito. Isto resulta também do fato que, n'A República e nas Leis, ou seja, nos diálogos em que Platão constrói os modelos teóricos para um estado mais ou menos ideal, uma parte consistente da legislação tem como finalidade específica justamente a educação. Assim, é importante notar que o esqueleto teórico d'A República é constituído pelo paralelismo entre estruturas psicológicas inerentes ao indivíduo e estruturas sociais inerentes ao estado, e isso demonstra mais uma vez o 
quanto as duas perspectivas estejam intimamente relacionadas.

À luz de tudo aquilo que dissemos, parece bastante inútil tentar distinguir, entre as obras de Platão, aquelas dedicadas especificamente à ética e aquelas dedicadas à política. De toda forma, foi observado que na tradição imediatamente posterior a Platão - primeiramente em Aristóteles -, o confronto sobre temas políticos teve como principais pontos de referência o Politico e as Leis, mais do que A República. De fato, o tema central d'A República é a natureza da justiça e as relaçōes entre essa virtude e a felicidade/infelicidade dos indivíduos que a praticam; ao invés disso, a análise política é apresentada como uma longa digressão, cujo objetivo consiste justamente em encontrar os instrumentos para responder aos problemas éticos enunciados acima.

Todavia, não seria correto dar peso excessivo a esses dados. Por um lado, a teoria política contida n'A República é muito ampla e articulada para poder realmente ser considerada apenas e simplesmente uma digressão. Por outro lado, n'A República estão contidas as mais interessantes e incisivas (mesmo que muito problemáticas) propostas políticas de Platão, razão pela qual uma análise do pensamento platônico focada sobretudo no Politico e nas Leis não faria justiça nem à força inovadora, nem à longa história do platonismo político, que animou a posteridade. Por isso, sustentamos que uma adequada exposição do pensamento político de Platão deva considerar, em primeiro lugar, precisamente $A$ República. 


\section{A JUSTIÇA E SUA RELAÇÃO COM A FELICIDADE}

O primeiro livro d'A República (que tem ao todo dez livros) possui a estrutura de um típico diálogo socrático que pergunta pela definição de algo. Como dissemos, o tema central é a natureza da justiça. Sócrates limita-se aqui a refutar algumas opiniōes correntes sobre o argumento: a mais tradicional, exposta por Polemarco, segundo a qual a justiça consiste em fazer bem aos amigos e o mal aos inimigos (331e-332a); e a provocatória, do sofista Trasímaco, segundo a qual a justiça seria o útil de quem estivesse no poder (338c). Mas, Sócrates se mantém fiel ao seu comportamento dos primeiros diálogos, e não oferece nenhuma resposta sua, mostrando querer se ir embora, como se tivesse concluído sua missão.

Se, todavia a discussão não termina nessa passagem, é porque Adimanto e Gláucon não se contentam e pedem a Sócrates, no início do segundo do livro, para não se limitar apenas à refutação, mas tentar resolver o problema de modo positivo. E Sócrates atende seu pedido.

$\mathrm{Na}$ passagem do primeiro ao segundo livro d' $A$ República, nota-se frequentemente, não sem motivo, um distanciamento, por parte de Platão, do método puramente refutador típico do Sócrates histórico. Platão adotou o método do seu mestre não só porque lhe era útil para contestar os falsos saberes comuns do seu tempo, mas também porque a demolição das ideias er- 
rôneas delimita o campo da pesquisa, permitindo que se tenha algum progresso em direção à verdade. Todavia, é indubitável que, para Platão, a filosofia deve ser capaz de produzir também algo mais. Além de tudo, não era totalmente evidente que a ação educativa de Sócrates tivesse tido um sucesso real. Ou melhor, existiam a esse respeito indícios fortemente contrários.

Pensemos, por exemplo, na dramática dissociação intercorrida em 399 entre Sócrates e a cidade, entre o filósofo e a política. Há passagens em que Platão nega a qualificação de educadores a alguns homens políticos famosos do passado, somente porque foram submetidos a processos, ou a ostracismos (Górgias 515d-517a). Poderia Platão não ter percebido que esse argumento valia também para Sócrates? Por isso, a partir do segundo livro d'A República, encontramos não apenas um Sócrates definitivamente mais platônico, mas também um Sócrates menos atento às definições abstratas e à análise das virtudes, e mais disposto a precisar suas concepções éticas, acomodando-as na vida concreta e confrontando-as com ela.

Como dissemos, a incumbência de reacender a discussão é assumida por Gláucon e Adimanto, a partir do segundo livro. Já mostramos antes suas observações sobre o tema da religião (cap. 3, pp. 35-6), por isso, agora nos limitaremos a tratar da justiça. Gláucon observa que para os homens em geral a justiça não é um fim em si, mas um fim para obter algo; como demonstra o fato de que bem poucos, se estivessem certos de não serem surpreendidos, se absteriam de co- 
meter más ações. Adimanto continua, mostrando que quem louva a justiça o faz em função dos bens que ela oferece (por exemplo, a boa reputação), enquanto os poetas proclamam que a justiça é bela, mas difícil de realizar (e com a injustiça ocorre o oposto). No que diz respeito às punições, tanto humanas quanto divinas, elas podem ser dribladas de diversas maneiras (as humanas, pela ocultação e pela fraude; as divinas, pelo sacrifício e a oração).

Gláucon e Adimanto não intervêm com o intuito de defender a posição de Trasímaco, mas com intenção provocadora. Eles querem saber se Sócrates possui bons argumentos para demonstrar que a justiça é um bem que mereça ser escolhido por si mesmo. Isso significa que esse bem deve ser capaz de tornar o homem feliz, assim a justiça não se deve transformar em um instrumento para alcançar outros fins, nem os homens devem ser induzidos a escolher a injustiça como um meio para serem felizes. Com isso são delimitados os limites da pesquisa, que se move totalmente no interior do eudemonismo ético que conhecemos bem (cap. 2, pp. 24-7). A resposta de Sócrates às objeções de Gláucon e Adimanto (que constitui o corpo teorético d'A República) é uma tentativa de mostrar a possibilidade da virtude e a felicidade poderem coincidir. 


\section{O ESTADO IDEAL: A DIVISÃO DAS \\ TAREFAS E A EDUCAÇÃO DOS GUARDIÕES}

Sócrates sugere que se analise o problema num campo mais amplo, de modo a que se possam facilmente identificar as características da justiça (368c369a). Esse alargamento será representado pelo estado: uma vez estabelecido o que é a justiça no estado, poder-se-á entender, por analogia, o que é a justiça no homem.

O estado é necessário porque há muitas necessidades na sociedade, entre as quais, em primeiro lugar, as materiais (a casa, o alimento, o vestuário, etc.). Para satisfazer tais necessidades, é necessário efetuar uma rígida divisão de tarefas, de modo que cada um se ocupe somente das atividades para as quais tem propensão e elas sejam, assim, realizadas da melhor maneira (369b371b). Este tema (isto é, a chamada teoria das competências) já tinha sido exposto várias vezes por Platão nos diálogos socráticos. A condição para o sucesso em qualquer atividade é o conhecimento técnico dos seus procedimentos. Uma sociedade onde não haja uma correta divisão das competências, e onde os homens ou grupos pretendam exercer funções sobre as quais não possuem um conhecimento adequado (basta pensar no suposto saber de poetas, políticos, sofistas, etc.), viverá em eterna desordem e estará destinada à autodestruição. Por isso, é importante criar uma classe de cidadãos preparada para satisfazer as necessidades materiais: a esse grupo serão delegadas as atividades 
produtivas e comerciais. Essa primazia reservada às necessidades mostra logo, contra preconceitos recorrentes, que o estado ilustrado n'A República é um modelo ideal, mas não idealístico, porque esse modelo, apesar da excelência daquilo que descreve, se constrói a partir do que os homens efetivamente são.

Mas as necessidades aumentam e se complicam progressivamente. Os homens não se contentarão com a simples subsistência (se assim fosse, seria uma sociedade de "porcos", afirma sarcasticamente Gláucon, 372d) e desejarão bens maiores. Assim nascerão novas atividades e novas classes de produtores, até o território não deixar de ser suficiente para conter os habitantes do estado. Desse conflito de interesses nascem as guerras entre nações.

A inevitabilidade da guerra impóe o nascimento de uma segunda classe, a dos guardiōes ou guerreiros, que terão a tarefa de defender o estado. Porém, os guardiōes não são somente soldados tecnicamente competentes na arte da guerra. Nem são só suficientes algumas qualidades físicas. Como cães bem treinados, devem ser capazes de ser duros com os inimigos, mansos e benevolentes com os amigos. De um ponto de vista meramente natural, parece que tais qualidades são opostas, e consequentemente incompatíveis. De fato, a natureza não é suficiente. Para que possa ser dócil e violento, dependendo do caso, é claro que o guardião deve saber quando e com quem exercer essas duas atitudes opostas. Deve saber reconhecer quem é amigo e quem é inimigo, por isso (e aqui podemos 
introduzir um dito platônico) deve conhecer o que é o bem e o que é o mal. Portanto, é necessário que o guardiāo seja filósofo (376c). Isso vale, antes de tudo, para o sentido etimológico da expressão "amante da sabedoria"; mas, naturalmente, tal qualificação confere ao guardião uma responsabilidade mais ampla de defesa e custódia do estado, na forma do conhecimento e partilha dos valores éticos fundamentais sobre os quais o estado se sustenta. O problema agora é estabelecer como os guardióes podem se transformar em "filósofos", ou seja, qual será o modelo educacional mais adequado para se alcançar essa meta.

Os guardiōes devem ser educados mediante ginástica e música (e a música abrange todas as disciplinas humanístico-literárias). Essa divisão se baseia no fato que o homem é composto de duas naturezas diversas: corpo e alma. A ginástica e a música são necessárias e devem colaborar para o mesmo fim, isto é, produzir nos indivíduos a harmonia psicofísica, ou seja, uma uniformidade equilibrada de intençôes e comportamentos.

A educação à filosofia não se dá somente por uma simples conversão da alma do sensível ao inteligível, porque tal conversão deve ser cuidadosamente preparada através da formação do caráter e, de maneira geral, mediante a educação dos impulsos e dos comportamentos instintivos. Esse objetivo é bem visível no modo através do qual Platão interpreta a música e a ginástica. $\mathrm{Na}$ música (que engloba a literatura em geral) não só devem ser excluídos aqueles assun- 
tos que possam causar danos para a saúde da alma, mas também descrições irreverentes de deuses e heróis, ou representações de modelos comportamentais negativos (a paixão excessiva, a indulgência para com o ridículo, etc.). Também devem ser excluídas as harmonias lamentosas ou lânguidas, substituindo-as por harmonias austeras, capazes de estimular a coragem e a firmeza. Igualmente devem ser evitados os ritmos irregulares, que são mais apropriados a, e se acordam com, os vícios, e devem ser promovidos os ritmos que possuem qualidades contrárias (399c-403c).

Da mesma maneira, o cuidado com o corpo deve visar não só a saúde, mas também o desenvolvimento de determinadas atitudes morais no homem, como o equilíbrio e a temperança. Nesse sentido, Sócrates pode dizer que tanto a música quanto a ginástica têm a alma como principal objetivo (410c), o que significa que o corpo mantém sua natureza essencialmente instrumental. Mas, com relação aos diálogos precedentes, esse caráter instrumental amplia-se, tanto que o corpo pode até mesmo se transformar em instrumento educacional da alma. Se n'A República é dado um juízo profundamente negativo àqueles que praticam a ginástica sem se ocuparem da música (ou seja, cuidam somente do corpo e ignoram a alma), também é negativo o juízo de quem faz o oposto, porque se torna muito flácido e relaxado. A conclusão é que é necessária uma boa harmonia das duas naturezas (410e-412a), porque só assim o homem poderá obter ao mesmo tempo coragem e sabedoria (temperança). 


\section{CRITÉRIOS DE SELEÇÃO, TAREFAS E CONDIÇÕES DA VIDA DE GOVERNANTES E GUARDIÓES}

Resta-nos agora dizer como serão escolhidos, entre os guardiões, os que deverão governar. Para isso, Platão enuncia um dos princípios fundamentais de todo o seu pensamento político. Sabemos que os governantes, se verdadeiramente o forem, devem tender para a realização do bem do estado. Mas se sentirá realmente solicitado a fazer o bem do estado somente aquele que defender que o bem-estar (ou felicidade) do estado coincide com o seu bem-estar (ou felicidade) pessoal (412d). Sócrates reconhece que é inútil esperar um comportamento justo e correto de uma pessoa, particularmente de um governante, que entenda que entre o seu bem e o do estado existem diferenças. Porque esse homem, ou esse governante, agirá de modo justo somente na medida em que temer arcar com as consequências, mas, em todos os outros casos, ele seguirá infalivelmente aquilo que acredita ser do seu interesse, e deixará de lado o interesse do estado.

Também aqui se pode constatar o quanto a construção política d'A República é pouco idealista (ao menos no sentido pejorativo que se confere a esse termo). Platão não pretende que os governantes tenham de preferir o bem comum em detrimento de suas vantagens pessoais. Isto seria, de fato, utópico e irrealista. Nem serve muito, para atingir esse fim, escolher uma forma de governo ou outra. Independentemente da 
forma que se escolha, no alto da escala de poder existirá alguém que não tem ninguém a comandá-lo. Como se pode esperar que esse indivíduo se preocupe com o bem do estado e não com o seu? A única possibilidade verdadeiramente realista para conseguir esse resultado é encontrar uma classe que faça o bem comum porque o considera idêntico ao bem particular.

Exatamente por esse motivo Platão acreditava que nem todos os homens possuíam as qualidades requeridas para se tornarem governantes. Os candidatos a essa função devem ser escolhidos com cuidado, com base em atitudes naturais, educados com a máxima atenção, de modo que tais qualidades se desenvolvam e não se corrompam, depois devem ser examinados periodicamente. Mas Platão tinha consciência de que essa seleção comportamental pode facilmente parecer detestável. Para isso, ele inventa a mentira útil do mito das raças, readaptando um conto de Hesíodo. A divindade criou os homens todos irmãos, mas distinguiu suas características: quem fosse destinado a governar tinha ouro mesclado em sua geração, aos auxiliares (isto é, aos guardiōes não governantes), prata, e aos trabalhadores, ferro e bronze. Mas, se naturalmente se espera que o filho dos homens de ouro possua as mesmas características do pai, todavia, essa não é uma regra absoluta, porque pode acontecer que os filhos sejam melhores ou piores. Por isso, será necessário inserir cada um na classe que lhe cabe em função de sua natureza, e não naquela que lhe caberia por nascimento $(414 \mathrm{~b}-415 \mathrm{~d})$. 
Para entender o sentido desse mito, não devemos nos esquecer que Platão se referia a uma sociedade onde tinha sido desenvolvido o culto da igualdade em todas as suas diferentes formas: uma parte da sofística prometia entregar a virtude em troca de pagamento, sem preocupação com as atitudes individuais, e todos se sentiam autorizados a emitir pareceres nas matérias mais díspares. Mas, para Platão, exatamente ao contrário do que pensava Protágoras, a virtude política não é qualitativamente diferente do talento necessário para tocar uma flauta, e que discrimina quem pode se tornar um ótimo flautista daquele que jamais conseguirá sê-lo. Platão tinha a intenção de mostrar ao seu público, formado sobretudo pela aristocracia de sangue e de dinheiro, que tanto o filho de um nobre como o de um latifundiário deveriam ser camponeses ou artesãos, se não fossem capacitados para cuidar do estado.

Portanto, é falso afirmar que, para Platão, a divisão do trabalho e o mito das raças exprimam uma concepção estritamente aristocrática da sociedade. Pelo contrário, as hipóteses platônicas levam em consideração as exigências que ainda são extremamente atuais: que cada um tenha a possibilidade de fazer de verdade aquilo para o qual tem talento, independentemente da classe em que nasceu.

Não só. A divisão de acordo com o talento corresponde para Platão a uma divisão segundo as necessidades, razão pela qual quem não tem índole para ser um governante é também uma pessoa que não quererá sê-lo, porque na vida do filósofo não se encontraria 
nada de útil para a sua felicidade. Uma demonstração implícita desse fato se encontra nas últimas páginas do terceiro livro, onde Sócrates teoriza aquilo que mais tarde se tornou célebre com o nome de "comunismo platônico”. Os guardiōes (e também os governantes) não deveriam possuir nenhum bem particular, como casas ou dinheiro, e receberão tudo aquilo de que necessitem para sua subsistência dos outros cidadãos (415d-417b).

O objetivo destas disposiçôes é fazer com que a interferência dos interesses privados não corrompa a pureza da finalidade à qual governantes e guardiōes devem se dedicar inteiramente: proteger o estado e promover o seu bem. Platão não queria com isso demonizar o dinheiro e as riquezas. Ele queria simplesmente dizer que quem visa a riqueza material não está qualificado para ser um governante, porque se transformaria em um patrão odioso para os outros cidadãos; mas poderá exercer legitimamente seu talento para as atividades econômicas e promover o próprio lucro pertencendo à classe dos produtores. Em um estado bem organizado, o poder econômico e o poder político devem ser separados, porque quem se interessa pelos bens materiais inevitavelmente terminará por sobrepor esse interesse ao bem comum. A divisão de classe não deveria, por isso, criar nenhum ódio ou inveja recíprocos, porque nada seria subtraído de ninguém, e todos estão no lugar onde desejariam estar. 


\section{A DIFÍCIL HARMONIA ENTRE INTERESSE PÚBLICO E PRIVADO}

Mas estamos seguros de que seja exatamente assim? Não é talvez verdade, como sugere Adimanto no início do quarto livro (419a-420a), que os guardiōes são um tanto quanto penalizados? Sócrates responde que, na construção do estado ideal, não devemos cuidar da felicidade individual, mas da felicidade do grupo, e se tal objetivo requer o sacrifício parcial de poucas pessoas, não se deve hesitar (420b-421c). O estágio educacional dos guardióes descrito nas páginas anteriores ganha, assim, um significado inquietante. Governantes e guardiōes serão induzidos pela educação e pelo hábito a assumir e manter os comportamentos adequados ao bem-estar do estado, e a crer que apenas tais comportamentos são capazes de fazê-los felizes; mesmo que, em qualquer medida, tal crença dependa do fato que foram privados da possibilidade de escolha e que foram programados desde o nascimento para realizar um determinado objetivo.

Platão parece ter consciência do fato que o problema de conciliar os interesses individuais com os coletivos é de certo modo insolúvel. Seguindo a estrutura geral da sua ética ele é levado, por um lado, a dar ênfase ao tema da felicidade; por outro, precisamente esse tema representa um perigoso detonador quando se reconhece que a felicidade do homem (mesmo a do filósofo) não pode ser contida nos limites estreitos da virtude e do bem entendidos em sentido platônico. $\mathrm{O}$ 
que faz um homem feliz, e quando se pode dizer que uma coisa é boa?

Para responder a essa pergunta Platão segue um princípio obscuro, que, porém, agiu em profundidade na tradição cultural e filosófica dos gregos: o imóvel é melhor que o móvel, o simples é melhor que o complexo, o uniforme é melhor que o variado, a unidade é melhor que a multiplicidade, etc. Com base neste princípio, pode-se demonstrar que os "bens" aos quais os guardiōes renunciaram não são bens de verdade (não são bens especificamente para eles). A resposta de Sócrates à objeção de Adimanto demonstra que o próprio Platão devia ter pelo menos algumas dúvidas a esse respeito. Mas essas dúvidas são rapidamente postas de lado, porque é muito forte a exigência de demonstrar que a virtude pura é desejável por si só: condição sem a qual, para Platão, não existe ética nem política. Como veremos, no Político e nas Leis, o rigor d'A República será de certa forma atenuado. Mas o princípio fundamental permanecerá o mesmo.

\section{A JUSTIÇA}

Uma vez detectada a natureza da constituição ideal, Sócrates pode estabelecer o que é a justiça no estado. É possível instituir uma correspondência aproximada entre as três classes de cidadãos e determinadas virtudes. Típica dos governantes que são filósofos (ou seja, os amantes da sabedoria), é a sophia, que justamente 
significa sabedoria (428c-429a). Platão não especifica em que consiste essa sabedoria, mas se trata do conhecimento do que é bem e mal de maneira geral, e aqueles que têm a tarefa de decidir as sortes do estado devem possuí-lo de maneira plena. Naturalmente, tal saber é privilégio de poucos e, por isso, a classe de governantes é particularmente exígua.

Característico dos guardióes, que têm a tarefa de defender o estado, é a andréia, uma palavra que significa coragem, mas também engloba em si a força e determinação da alma em geral. A coragem também é uma forma de saber, porque consiste na capacidade de manter firme a própria opinião a respeito das coisas que se devem temer e das que não se devem (429c), portanto, também depende do conhecimento do bem.

A terceira virtude, ou seja, a sophrosyne (sabedoria ou temperança) não pertence somente a uma classe, mas de certa maneira a todas. De fato, trata-se da virtude que gera ordem e moderação na esfera dos desejos e dos apetites, fazendo com que os apetites da maioria medíocre sejam dominados pelos apetites (mas sobretudo pela inteligência) da minoria melhor (431d). A temperança é, por isso, conhecimento do que é melhor e pior no mundo dos desejos e o acordo entre eles, fundamentado sobre o fato que os melhores governam os piores (432a).

A justiça obtém-se por exclusão das três virtudes que acabamos de identificar. Ela não é tanto uma virtude específica, mas é a qualidade que permite às outras virtudes nascerem e se conservarem (433b): é 
a virtude em função da qual cada um exerce apenas sua tarefa, ou seja, aquela que lhe foi especialmente atribuída para que a desempenhe da melhor forma. A injustiça, pelo contrário, nasce quando os cidadãos desempenham tarefas que não são de sua competência (particularmente, quando um artesão quer ser um guardiāo ou quando um guardião quer ser um governante).

A divisão das virtudes reflete a divisão dos cidadãos em classes, e se deve ao fato que o saber mais elevado pertence somente a poucos, enquanto a grande maioria dos homens pode, no máximo, obter esse saber refratado a partir das próprias características individuais. Dessa maneira, o artesão temperante não possui um conhecimento do bem igual ao do filósofo, mas o suficiente para saber que o bem é precisamente aquilo que o filósofo lhe indica, e não o que poderia parecer tal ao seu juízo superficial.

\section{DO ESTADO AO INDIVÍDUO:}

\section{A ALMA E SUAS VIRTUDES}

Uma vez estabelecido o que é a justiça no estado, o discurso pode retornar à pergunta inicial e esclarecer, por analogia, o que é a justiça no indivíduo, ou seja, na alma. Porém, a analogia só pode funcionar se também a alma for composta de três partes, tal como o estado. Aqui encontramos a doutrina da tripartição da alma, que já foi exposta anteriormente (cap. 8, pp. 91-2): 
parte racional, parte animosa e parte concupiscível. A estas três partes da alma correspondem as mesmas três virtudes características das classes dos cidadãos: sabedoria para a parte racional, coragem para a animosa e a temperança para a parte concupiscível (embora a temperança seja virtude comum a todo o estado e a toda a alma). A justiça consistirá, da mesma forma, na manutenção da ordem hierárquica, de modo a que a razão governe as outras duas partes. Em particular, é necessário que a parte racional e a animosa se aliem o máximo possível para conterem os impulsos desenfreados da parte concupiscível (441c-443b).

A doutrina da tripartição da alma possui um significado político importante, que vai além da correspondência entre as partes da alma e as classes do estado. Acima, vimos que, para Sócrates, pelo menos como é representada na Apologia e no Fédon, a alma coincide substancialmente com sua razão. Mas, dessa maneira, não apenas se desenvolve uma imagem hiperracionalista do ser humano, mas também se cria uma substancial fratura entre um modo ideal, como as coisas deveriam ser (ou seja, reguladas só pela razão) e o modo real, como as coisas efetivamente são (que é o mundo das relações sociais e políticas).

Com base nisto, o diálogo entre as duas partes torna-se impossível e, consequentemente, impossível também será a colaboração entre política e filosofia. Se, ao contrário, tal colaboração representa a única resposta possível ao problema político, é necessário não só que a política se resigne a seguir a filosofia, mas 
também que a filosofia entenda realmente como são os homens: isto é, que não são e não podem ser puramente razão. Se é verdade que os impulsos irracionais existem dentro da alma, então é claro que o filósofo não pode mais fugir, com sua linda e lúcida racionalidade, do mundo perverso dos desejos, porque tais desejos são parte integrante do seu próprio ser. Então, o filósofo não poderá mais evitar a vida política, porque é a própria natureza da sua alma que lhe impõe a necessidade de governar: primeiro, dentro de si; depois, logo, por analogia, no estado.

\section{AS “TRÊS VAGAS”: PARIDADE HOMEM- MULHER, CONTROLE DA REPRODUÇÃO E GOVERNO AOS FILÓSOFOS}

No início do quinto livro, logo depois de ter falado das virtudes, Sócrates começa a descrever também as formas erradas de organizar a alma e o estado (que são quatro). Mas sua exposição é interrompida, de comum acordo, por seus interlocutores, que desejam ter um esclarecimento sobre o que ele havia dito antes. De fato, em um certo momento da discussão, Sócrates havia dito en passant que, entre os amigos, as coisas e as mulheres devem ser de uso comum (424a), mas não havia explicado bem o que queria dizer, particularmente no que diz respeito à comunhão das mulheres.

A discussão que se segue é articulada por Sócrates em três "vagas", ou seja, como tentativa de demonstrar, resistindo ao ataque inevitável da opinião 
comum, três princípios políticos aparentemente paradoxais. Antes de tudo (primeira vaga), Sócrates se pergunta se as mulheres pertencentes à classe dos guardiões devem desempenhar as mesmas atividades realizadas pelos homens e, consequentemente, receber a mesma educação. A resposta é afirmativa, porque as diferenças naturais não possuem o mesmo peso em relação a todas as atividades e, em certos casos, chegam a ser irrelevantes. Por exemplo, não haveria nenhum sentido estabelecer que os calvos poderiam ser sapateiros e os cabeludos não, porque essa diferença física não tem nenhuma relação com a atividade do sapateiro. A mesma coisa vale para as diferenças entre homens e mulheres. O princípio estabelecido por Platão, que vale também para a modernidade, é que as mulheres cumprirão as mesmas atividades que os homens nos casos e na exata medida em que as diferenças naturais não sejam significativas. Portanto, também as mulheres tomarão parte na educação, na guerra e no governo (451c-457b).

Ainda mais difícil é tratar da segunda vaga. Platão propõe que os guardiōes copulem para procriar sob um monitoramento rígido dos governantes, os quais, recorrendo às vezes também ao engano (por exemplo, falsos sorteios), regularão a reprodução com métodos que hoje chamaríamos "eugenéticos": os melhores copularão com os melhores, para que os filhos sejam o mais excelentes possível, enquanto os indivíduos de natureza ruim terão a reprodução proibida ou dificultada. No que diz respeito aos filhos, as coisas serão iguais: somente os sãos e de boa estirpe poderão ser 
criados de maneira pública e digna, enquanto os outros serão escondidos em lugares isolados. Não se poderá falar propriamente de famílias, porque o governo fará com que ninguém saiba verdadeiramente quem é seu filho, estabelecendo que todos os nascidos em um certo período chamem pai e mãe a todos os que tenham reproduzido no período correspondente, e que estes últimos considerem todos aqueles como seus filhos, sem distinção (457b-461e).

Os princípios que expusemos pertencem aos mais discutidos e contestados de toda a construção política d'A República. Impressiona, em particular, não ver em Platão um sentido de respeito pela vida enquanto tal, mas apenas na medida em que quem vive tenha a possibilidade ou a virtude de fazer algo de bom. $\mathrm{Na}$ realidade, os antigos não consideraram estas normas muito escandalosas, porque o respeito pela vida, sobretudo na sua fragilidade e fraqueza, é um tema decorrente do cristianismo. Aos contemporâneos de Platão, mostrou-se muito mais paradoxal a comunhão das mulheres. Essa norma é inspirada no mesmo princípio sobre o qual se estabeleceu a comunhão dos bens. Dessa forma, Platão pensava concretizar aquela identidade entre interesse público e privado essencial para que os guardiōes e os governantes se ocupassem verdadeiramente do bem do estado (465d-466d). Em uma sociedade na qual todos os bens sejam comuns não poderão surgir discórdias, porque elas derivam justamente dos desejos contrastantes de ver prosperar o que é particular às custas do que é de outrem; e isso 
vale também para aquele tipo particular de propriedade que são os filhos.

Quando Sócrates anuncia pela primeira vez a lei sobre a comunhão das mulheres, Gláucon contrapõese afirmando que tal lei poderia não ser útil nem realizável (457d). Em sua resposta, Sócrates convida o seu interlocutor a distinguir os dois problemas, e pede licença para tratar do segundo só depois de ter esgotado o primeiro.

O motivo dessa escolha de método é esclarecido no momento em que Sócrates introduz a terceira vaga, ou seja, quando se prepara para discutir sobre a possibilidade de realização do estado descrito. Ele lembra que a discussão tinha a intenção de delinear o estado perfeito com o objetivo de estabelecer o que era a justiça. Platão quer, com isso, ressaltar que o objetivo do diálogo não é construir concretamente um estado, mas detectar um modelo ideal (472a-b). A consecução desse objetivo é a premissa necessária para examinar o discurso da realização. Não se deve pretender que o homem e o estado justo se adequem exatamente ao modelo (473a-b). Mas a definição do modelo é o passo obrigatório para encontrar um parâmetro que sirva de base para estabelecer a medida da justiça: tanto mais justos serão um homem e um estado quanto mais se aproximarem do modelo descrito, e tanto mais injustos serão quanto mais se afastarem dele (concepção idêntica é exposta também nas Leis; ver, por exemplo, 746a-d).

Deste modo, se esclarece o significado da frequentemente incompreendida utopia platônica. A utopia 
é necessária não porque a realidade possa ou deva ser de tal gênero, mas porque fornece uma imprescindível medida de regulação. Para saber em que direção mover-se, é preciso saber qual é a meta, mesmo sabendo-se que essa meta nunca poderá ser alcançada. De fato, para Platão, vigora uma distinção precisa entre fatos e valores, em função razão pela qual é necessário primeiramente estabelecer os valores, para depois decidir, com base nisso, em que medida os fatos podem se conformar aos valores.

Se este percurso não foi ainda efetuado, nenhuma consideração preliminar é pertinente, nenhum princípio ou prática política tem valor. Particularmente, não têm valor nenhum dos apelos à tradição, ao costume, ao bom senso ou ainda a uma lógica apenas aparente. Considere-se, por exemplo, as normas relativas à reprodução e aos filhos. À primeira vista, elas parecem ilógicas, por serem aparentemente contrárias ao modo como homens e mulheres sempre se comportaram segundo as leis e a natureza. Mas, para estabelecer o que é justo, o único método pertinente é o do saber, e o único homem autorizado a dar definições é o filósofo. Se este princípio é válido, ao elaborar a teoria, não se deve recuar nem mesmo diante de consequências paradoxais; mesmo que, como admite Platão de forma explícita nas Leis, depois seja inevitável renunciar a colocar em prática esses princípios que se revelam irrealizáveis praticamente. Por isso, quando examina o problema da possibilidade da realização do estado perfeito, Sócrates enuncia a célebre condição segundo 
a qual os governantes devem se transformar em filósofos ou vice-versa (473c-d), é claro que Platão não está aqui revelando os procedimentos capazes de colocar em prática uma teoria, mas está indicando a direção ideal para a qual se deve mover, caso se deseje criar algo que se pareça o máximo possível com o bem.

Dizer que a única solução possível dos problemas do estado consiste em dar o governo aos filósofos é uma afirmação tão paradoxal, para a cultura corrente, quanto as afirmações relativas ao papel das mulheres e à reprodução. $\mathrm{O}$ tema da aparente incapacidade do filósofo já tinha sido abordado por Platão em outros diálogos (por exemplo, no Górgias e no Fédon). O propósito d'A República é aprofundar esse problema, isto é, ilustrar de modo mais completo possível a verdadeira natureza do filósofo, para mostrar que sua aparente incapacidade política deriva de representaçóes que distorcem suas características.

Quem é então o filósofo? O filósofo é aquele que deseja o saber na sua totalidade e completude, por isso, pode ser definido como aquele que ama contemplar a verdade (475e). Essa definição é esclarecida depois pela teoria das ideias: o verdadeiro filósofo difere do amante comum de espetáculos, ou seja, do homem que contempla coisas superficiais (trata-se do filodoxo, do qual falamos no cap. 7 , pp. 81-4), porque o objeto do seu amor não são as coisas que se percepcionam com os sentidos, mas aquelas que se apreendem com o intelecto e com o pensamento, e consistem no justo, no bem e no belo em si. 
A natureza do saber ao qual aspira o filósofo é a qualidade decisiva para fazer dele o único homem verdadeiramente político. O filósofo ama conhecer o modelo eterno e, por isso, possui uma visão das coisas e uma capacidade modeladora visando ao bem que falta ao homem comum. Além disso, é sincero por natureza, porque ama a verdade; não se interessa pelos bens materiais, porque aprecia somente os prazeres da alma; é capaz de observar as coisas de um ponto de vista universal, não só do seu ponto de vista pessoal; aprende com facilidade, porque é a isso mesmo que tende seu desejo; é amante do equilíbrio e da medida, porque tal é o modo de ser que tem afinidade com a verdade (484a-487b).

Podemos dizer que o problema foi definitivamente resolvido? Existe ainda uma última questão. Como objeta Adimanto, pode-se constatar que os homens que se dedicaram à filosofia até a velhice se transformaram em misantropos alheios à sociedade civiliza$\mathrm{da}$, até o ponto de se tornarem inúteis para a cidade (487c-d). Mas, na realidade, também para isso há uma explicação. Se o filósofo pode parecer inepto, é simplesmente porque as pessoas comuns não são capazes de compreender a sua verdadeira natureza e porque ele é efetivamente inadequado para viver de maneira ativa na corrupção moral e política que invadiram todos os regimes correntes. 


\section{AS DIFERENTES CONSTITUIÇÕES E OS CORRESPONDENTES TIPOS HUMANOS}

Para entender a natureza do filósofo e do saber ao qual ele aspira, Platão insere, nos livros sexto e sétimo d'A República, as explicações de ordem epistemológica e metafísica que já tratamos no capítulo 7. Essa colocação particular confirma mais uma vez que a "metafísica" de Platão não deve tanto ser entendida como uma tentativa de apreender os princípios primários da realidade determinados por uma intenção puramente teorética (como, ao contrário, é o caso de Aristóteles), mas como uma busca daqueles princípios que podem e devem ser utilizados para produzir a vida boa no âmbito público e privado, justamente como se a política pudesse ser comparada às outras "técnicas" produtivas (ver cap. 2, pp. 26-7). A incidência desse modelo é confirmada por Platão no início do livro sétimo, onde se diz que o filósofo fará uso do conhecimento das ideias o máximo possível, com o objetivo de "estabelecer para o nosso mundo os cânones relativos às coisas belas, justas e boas" (484c-d).

A conclusão ético-política do percurso feito no diálogo encontra-se, por sua vez, nos livros oitavo, nono e décimo. Dando continuidade ao discurso introduzido no início do livro quinto, no oitavo, Sócrates passa a descrever as quatro formas degeneradas de estado, e as quatro características psicológicas correspondentes. A linha de pesquisa é ainda aquela que fora anunciada no segundo livro, ou seja, a analogia entre estado e 
indivíduo, entre política e moral. Mas agora a análise política recupera todo o seu significado metafórico e o curso da pesquisa se alinha de forma mais estreita ao objetivo proposto a partir das questōes de Gláucon e Adimanto, isto é, o de demonstrar que a prática da justiça é o melhor modo de conduzir a existência, mesmo nos termos do "bem-estar" e da felicidade.

As constituiçōes corruptas (em ordem crescente de imperfeição) são a timocracia (realizada em Creta e Esparta), a oligarquia, a democracia e a tirania. O estado perfeito é definido como a aristocracia, no sentido etimológico de "governo dos melhores" (544e). Platão imagina que esta última constituição foi realizada e ilustra sua progressiva decadência em formas políticas sempre piores. Mas, como é possível essa degeneração? A resposta de Platão é irônica. Em uma passagem cheia de difíceis raciocínios matemáticos, Sócrates afirma que chegará necessariamente o momento em que os governantes não serão capazes de conhecer o "número nupcial" que regula as reproduções (546d), de maneira que nascerão homens inadequados para realizarem a tarefa que lhes será dada. Deixando de lado a metáfora, Platão quer dizer mais uma vez que o estado que descrevemos é um modelo ideal, que poderia existir eternamente como as ideias apenas fora do tempo e do ciclo da geração e da corrupção (ver $592 b$ ): de fato, tudo aquilo que nasce está por natureza destinado a se corromper (546a).

Para cada uma das quatro constituiçóes, Platão descreve a dinâmica gerativa e as principais caracterís- 
ticas, tendo sempre presente que o verdadeiro objetivo é ilustrar as várias índoles individuais. Assim, o governo timocrático tem por base o culto da honra (timé) e o uso da força, a supremacia da ginástica em relação à música, e não é indiferente aos desejos de lucro e do bem-estar material.

Logo em seguida vem o governo oligárquico, fundado na opiniāo, no qual estão no poder os homens de negócios, que mantêm o predomínio sistemático dos ricos sobre os pobres. $\mathrm{O}$ homem oligárquico originase do insucesso do timocrata, que tenta obter com riqueza aquela posição de excelência que não obtivera por meio de honrarias. Sua característica é o impulso de transformar tudo em dinheiro: ele "é o homem que acumula tesouros e o povo o admira" (554a-b). Mas justamente porque esse é o objetivo máximo da sua vida, o homem oligárquico é o clássico sujeito que pratica a justiça somente pelas vantagens que ela lhe traz e, que desde que não corra riscos, não hesitará em enriquecer, inclusive ilicitamente.

A passagem da oligarquia à democracia está também implícita na mesma natureza da oligarquia. Para satisfazer sua sede de dinheiro, os governantes oligárquicos encorajam a máxima liberdade na alienação dos bens, assim, a um número cada vez menor de homens ricos se contraporá uma grande massa de homens empobrecidos e deserdados, por natureza revoltados, que se tornarão fortes por serem numerosos e tomarão o poder com uma revolução violenta. Nasce assim a democracia, ou seja, o regime onde vigora a máxima 
igualdade e os cargos públicos são distribuídos principalmente através de sorteio.

O regime democrático, promovendo a mais ampla liberdade e tolerando qualquer modo de vida, pode parecer exteriormente como o mais belo, quase como um tecido com matizes de múltiplas cores (557c). Também a vida que tem lugar na democracia pode, à primeira vista, parecer muito prazerosa. $\mathrm{O}$ problema é que a liberdade e a indiferença com relação à hierarquia dos valores que prevalecem na democracia não permitem distinguir os prazeres lícitos dos ilícitos, de modo que o homem democrático é aquele que passa de um prazer a outro sem refletir e de acordo com o gosto do momento; que se dedica a muitas e diversas atividades, sem respeitar o princípio pelo qual cada um deve fazer apenas aquilo que sabe fazer bem (558c-562a).

Enfim, a tirania nasce, por sua vez, da democracia, como consequência do excesso de liberdade. O homem democrático considera a liberdade um bem em si, e o antepõe a todos os outros valores. O resultado é que assim se subverte cada princípio de ordem e de autoridade, o pai passa a temer os filhos, o professor os alunos, os jovens se comportam como os anciãos e vice-versa (563a-b). Assim é eliminado da sociedade qualquer tipo de constrição. Mas é sabido que cada excesso provoca a reação contrária, pelo que, de uma liberdade desenfreada sobrevém muitas vezes uma rígida servidão.

O mecanismo dessa transformação merece ser analisado. O regime oligárquico deixou como herança ao 
regime democrático um bom número de ex-ricos empobrecidos, que tentam de todas as formas reaver sua riqueza. Por isso, a classe poderosa acusa-os diante do povo de serem oligárquicos, e o povo, por sua vez, para se defender, elege um líder. O líder, percebendo que o povo é demasiado obediente, exerce um poder cada vez mais absoluto e violento sobre o mesmo grupo que o apóia, cerca-se de guarda-costas "para defender o defensor do povo" (566b), até que se transforma efetivamente em um tirano. Depois, por um certo período, mostrar-se-á simpático e moderado; mas, ao mesmo tempo, provocará guerras, quer para defender a necessidade da ditadura, quer para desviar os súditos dos problemas internos; e também começará a eliminar os melhores, porque ameaçam seu poder, e se cercará dos medíocres, dos aduladores e dos escravos. Enfim, o tirano acabará por se colocar contra o mesmo povo, o qual, embora o tenha elegido, se revoltará contra ele (568d-569c). Assim, chega-se ao máximo da ruína, da injustiça e da discórdia em um estado, em tudo e por tudo, o oposto do bom regime "aristocrático!".

\section{INFELICIDADE DO TIRANO, FELICIDADE DO FILÓSOFO}

Platão descreve o homem tirano no livro nono, onde se serve dessa descrição para determinar o que torna verdadeiramente o homem feliz ou infeliz. Platão dedica uma atenção particular à refutação do ideal 
ético do tirano, e não é difícil entender porquê. Como sabemos ele aceita o princípio eudemonista relativamente vigente em toda a ética antiga. Por outro lado, é obvio que muitas pessoas poderiam raciocinar como Cálicles e, assim, atribuir sua felicidade à livre satisfação de todos os desejos (ver cap. 2, pp. 25-6). Em outras palavras, a moral tirânica não é tanto o modelo extremo no qual se inspiram indivíduos singulares ou excepcionais, quanto uma tentação recorrente comum a todos, dado que todos os homens podem ser erroneamente induzidos a acreditar que justamente essa moral seja o meio mais adequado para alcançar a felicidade. Uma clara referência ao tema pode ser encontrada justamente no início do nono livro, onde Platão admite que a espécie dos desejos terríveis, selvagens e estranhos a qualquer norma está presente em todos os homens, inclusive naqueles que parecem ser muito equilibrados (572b). Então, torna-se absolutamente essencial, para Platão, mostrar que o homem tirano está longe de obter a felicidade que todos desejam.

São três os argumentos que Platão coloca para demonstrar esta tese. Se compararmos o homem tirânico ao estado correspondente, constataremos que esse homem é escravo da sua parte pior, portanto, não é de todo livre, e nem se pode dizer que "faz o que quer". Pior ainda se observarmos a vida do tirano, veremos que se trata de uma verdadeira vida de escravo, repleta de medos e proibições (577c-580c).

A segunda demonstração é mais articulada. Se considerarmos as três partes da alma e dividirmos os 
homens em função da maior ou menor supremacia de cada uma delas no homem, devemos dizer que existem homens amantes da sabedoria (filósofos), homens amantes do sucesso e homens amantes do lucro. Cada um deles naturalmente louvará os prazeres que derivam do objeto de seu amor, e desprezará os outros. Mas estas três opiniōes não têm o mesmo valor: mesmo na ausência de outros critérios, a opinião do filósofo é mais verdadeira que as outras, porque só o filósofo provou de todos os prazeres e é capaz de julgá-los com a inteligência (581e-583a).

A terceira prova estrutura-se pela distinção de três estados psicológicos: a dor, o prazer e aquele intermediário, que não é nem doloroso nem prazeroso. As pessoas que atribuem a causa sua felicidade aos prazeres materiais movem-se unicamente entre a condição de dor e a condição intermediária, e ignoram em que consiste o verdadeiro prazer e a verdadeira felicidade. De fato, para Platão, existindo no homem tanto as necessidades do corpo quanto as necessidades da alma, a satisfação das primeiras representa a ausência da dor (portanto, pode conduzir somente ao estado intermediário), enquanto a verdadeira felicidade, ou seja, o bem em sentido positivo, pode ser produzido somente através da satisfação das segundas. Quem deposita sua felicidade nos prazeres do corpo ativa uma dialética interminável entre necessidade e satisfação, de modo que jamais poderá dizer-se feliz. Por outro lado, os prazeres da alma trazem a felicidade, porque são apenas bens que se juntam na sua pureza a uma condição que por si só é já livre da dor e do mal (583b-586c). 


\section{O DÉCIMO LIVRO: A NOVA ANÁLISE DA POESIA E O MITO DE ER}

Com a conclusão do nono livro d'A República, pode-se dizer que a discussão introduzida no segundo livro foi esgotada. Mas o diálogo prossegue com um livro ulterior, onde, em primeiro lugar, é tratado novamente o problema da arte e da poesia, e, em segundo lugar, se estabelece que a virtude receberá prêmios ultraterrenos, quer mediante a demonstração da imortalidade da alma, quer com o célebre e grandioso mito de Er.

Para perceber porque Platão volta a falar de arte, depois da ampla discussão do segundo e do terceiro livro, os estudiosos deram ênfase ao fato que não se trata de uma simples repetição, porque agora o problema é reexaminado à luz da teoria das ideias, introduzida nos livros centrais do diálogo. Como sabemos, os objetos sensíveis são imitações das ideias; mas as produçôes artísticas são, por sua vez, imitações desses objetos e, assim, situam-se três vezes mais distantes da verdadeira realidade (ou seja, são cópias de cópias). E isto já seria suficiente para desqualificar seu valor. Mas as obras de arte sofrem também de um outro defeito. $\mathrm{O}$ artista trabalha com o objetivo de reproduzir aquilo que imita assim como este lhe aparece, não como é. Isso significa que é possível ser artista e poeta sem ser expert em nada (597a-602b).

Portanto, a teoria das ideias permite acrescentar à crítica da poesia conduzida no plano ético (nos li- 
vros segundo e terceiro) também uma desvalorização intimamente ligada à estrutura metafísica da realidade. Mas talvez a tardia retomada desse tema encontre sua explicação, por assim dizer psicológica, na própria economia do diálogo. Precedentemente, Platão descrevera o homem democrático, criticando-o, não sem uma certa ambiguidade: no fundo, sua vida não é desprezível como a do tirano (572c-d) e é tão bela e variada que parece a melhor entre todas (557c). Em suma, embora a razão seja obrigada a se manter distante, trata-se de um modelo muito sedutor. Eis aqui um motivo provável pelo qual Platão torna a falar de poesia: para confirmar com argumentos tão fortes e resistentes, quanto mais cativante for a aparência contrária, que não existe nada de verdadeiramente belo além do bem e que, não obstante quaisquer sofrimento compreensível e constante tentação, é necessário expulsar a arte imoral e frívola do estado, porque não é verdadeiramente bela.

Terminada essa parte, o diálogo caminha para a sua conclusão. Ainda não se falou dos máximos prêmios e recompensas devidos à virtude; e nenhum prêmio pode ser verdadeiramente grande se se esgota no espaço da vida humana e não dura eternamente (608c-d). Mas se o prêmio tiver de ser eterno, a alma deve ser imortal. Portanto, Platão demonstra antes de tudo, com um argumento que já conhecemos (ver cap. 8, p. 86), que a alma não pode morrer.

Para falarmos do destino da alma depois da morte e dos prêmios e castigos que a esperam no além, Sócrates expõe o célebre mito de Er como encerramento, 
(614b-621d). Nesse mito são reconhecíveis três elementos principais: 1) uma descrição geográfica da terra e das suas partes (das quais não nos ocuparemos); 2) uma indicação dos prêmios e castigos que esperam as almas depois da morte; 3) uma acentuação muito forte da liberdade humana, contra as éticas da sorte e do destino.

Platão imagina que Er, um homem valoroso originário da Panfília, tenha tido a oportunidade de ver o que acontece após a morte, para depois poder contar aos outros: os homens maus são punidos nas vísceras da terra por um período que equivale a dez vezes o período da vida humana (isto é, aproximadamente mil anos), enquanto os bons desfrutam de um destino contrário no céu e pelo mesmo período. Ao fim desse ciclo, todos os homens (exceto os cruéis que se mostrarem incuráveis) são reconduzidos a uma nova vida. Aqui é introduzido o segundo tema, o da liberdade: as vidas sucessivas não são atribuídas pelo destino, mas são escolhidas por cada alma. O único elemento deixado ao acaso é a ordem dos turnos na escolha, que são sorteados. Mas a incidência do acaso não é determinante, porque o número de vidas é maior do que o de almas, de modo que quem escolhe por último tem a possibilidade de receber uma vida, se não ótima, pelo menos não má.

O motivo pelo qual Platão planejou essa bizarra narrativa da escolha da vida futura aparece com clareza naquilo que Láquesis (umas das três moiras, presentes no mito) diz às almas que devem reencarnar: "Almas 
de efêmera existência corpórea, inicia para vós outro período de geração mortal, prelúdio de nova morte. Não haverá um daimon para vos receber, mas sereis vós a escolher o daimon. O primeiro sorteado escolha primeiro a vida à qual estará irrevogavelmente ligado. A virtude não possui dono; na medida em que a honrem ou a prezem, cada um terá mais ou terá menos. A responsabilidade é de quem escolhe, o deus não é responsável” (617d-e).

Se observarmos bem, não é por acaso que, no último livro d'A República, esse mito está aproximado de uma severa crítica à poesia. Não só porque com o mito de Er Platão fornece uma prova concreta de como deveria ser a poesia na cidade perfeita, mas também porque as razões do fado e do destino irrevogável, a trágica visão dos homens vítimas de uma sorte que os deuses escolheram para eles, eram lugares comuns sobre os quais a poesia insistira com particular frequência: sobretudo a poesia épica e trágica, contra a qual Platão dirige sua crítica em primeiro lugar.

A confiança na possibilidade de o homem construir seu próprio destino é o tema que torna a filosofia de Platão antitrágica por excelência. A República pretende demonstrar, em seu conjunto, que a virtude e a felicidade que dela deriva podem ser livremente alcançadas pelo homem. Mas não é tudo. Contra a hipótese, parcialmente confirmada pela tragédia que foi o destino dramático do Sócrates histórico, segundo a qual a felicidade seria acessível somente a homens excepcionais capazes de escapar do mundo e das suas 
seduções, $A$ República quer provar que não somente é possível escolher o bem privado sem renunciar ao público, mas, sobretudo, que uma coisa não se dá sem a outra. Essa é a mensagem final d'A República: a virtude e a felicidade do homem, também do indivíduo, passam necessariamente pela política, entendida em sentido lato como educação completa do homem, quer na dimensão pública, quer na privada. Dessa maneira, Platão pode fechar o grande diálogo dizendo que as condiçôes que expusemos, se forem respeitadas, sem dúvida permitirão ao homem ser feliz (eu prattein), antes e após a morte. 


\section{AS IDEIAS, O CONHECIMENTO, A DIALÉTICA}

\section{OS “DIÁlOGOS DIALÉTICOS”}

\footnotetext{
Segundo a hipótese cronológica mais plau$\checkmark$ sível, pouco depois de ter finalizado A República, Platão começa a escrever os diálogos dialéticos, iniciando pelo Teeteto e pelo Parmênides. Nesses diálogos são discutidos e aprofundados assuntos que em obras precedentes tinham sido apenas esboçados; mas, sobretudo, são expostos e criticamente examinados problemas relativos à doutrina das ideias, que levam Platão a atualizar, senão exatamente retificar, suas conclusões até agora alcançadas. Isso é evidente especialmente no Parmênides, onde muitos elementos nos levam a supor que Platão esteja anunciando uma mudança, efetivamente concretizada depois no Sofista e no Filebo. Mas o significado dessa mudança não deve
} 
ser exagerado, porque os diálogos dialéticos não são a negação dos precedentes, mas pressupóem-nos e lhes dão continuidade. Não devemos esquecer que neles aparecem muitos temas já discutidos nos diálogos anteriores (basta pensar no retrato do filósofo do Teeteto, que aproxima esse texto do Fédon, ou na descrição do sofista no diálogo homônimo que o aproxima do Górgias). Mas esses temas agora aparecem filtrados pela escola e, de certa maneira, formalizados, enquanto, de um ponto de vista mais geral, se nota a tentativa de Platão de mostrar com mais amplitude a natureza do saber filosófico e os objetos deste saber (embora, como veremos, o característico círculo "técnico" entre saber teórico e atividade prática não é de nenhuma maneira interrompido). Começaremos falando do Teeteto.

\section{O TEETETO: O CONHECIMENTO É OPINIÃO VERDADEIRA?}

Se quiséssemos classificar os diálogos dialéticos com base nos reenvios internos, deveríamos dizer que após o Parmênides temos o Teeteto, depois, em sequência, o Sofista e o Político (quanto ao Filebo, porém, não podemos ter muitas certezas). As razões dessa divisão se encontram no Sofista: a cena de abertura indica que se trata de uma continuação do Teeteto; em 217c Sócrates alude a um diálogo que teve com o velho Parmênides quando ainda era muito jovem. Pouco antes, no mesmo diálogo, fora introduzido, como assunto 
geral das sucessivas indagações, a questão da definição do sofista, do político e do filósofo, onde se parece delinear um esquema que faz do Sofista e do Político as primeiras duas etapas; porém, fica faltando materialmente um terceiro diálogo intitulado Filósofo.

Contudo, do ponto de vista de uma sequência lógica, os acontecimentos se complicam um pouco. Enquanto uma parte importante do Parmênides é dedicada à discussão da doutrina das ideias, no Teeteto não temos nenhum sinal de tal teoria. De resto, a primeira parte do diálogo tem como objetivo a refutação do heraclitismo e do subjetivismo pitagórico, que tem um caráter preparatório em relação à teoria das ideias. Razão pela qual falamos disso antes (cap. 4, pp. 45-9). Na segunda parte do diálogo, porém, já é possível reconhecer temas que serão amplamente discutidos no Sofista: aqui, se trata, sobremaneira, de acordo com alguns pontos já presentes no Parmênides, de mostrar, pelo habitual método refutatório, quais são os vínculos aos quais a doutrina dos princípios deve se submeter, para poder verdadeiramente explicar o conhecimento e seus vários fenômenos (dentre os quais, o mais importante é o do erro).

Estabelecido, na primeira parte do diálogo, que o conhecimento não é sensação, Teeteto propõe definilo como "opiniāo verdadeira" (187b). Sabemos que esta expressão cumpre um papel importante na gnoseologia platônica dos diálogos socráticos: é um saber feliz, mas ocasional, de quem acerta na verdade sem conhecimento preciso e não sabe dar razão desse saber. 
Uma característica do Teeteto é que, nele, Sócrates não ataca a "reta opinião" do ponto de vista superior da ciência, mas se coloca do ponto de vista da própria opinião. Se falarmos da opinião verdadeira, devemos supor que existam também opiniōes falsas; mas a possibilidade de que existam falsas opiniōes é um fato altamente problemático.

O modo pelo qual Platão desenvolve essa questão atinge momentos de sutil minúcia dialética, mas aqui nos limitaremos a invocar somente as passagens essenciais. A análise parte do conhecer e do não conhecer em geral. É claro que cada homem conhece aquilo que conhece e não conhece o que não conhece. Então, não é possível nem que quem conheça uma coisa presuma que seja uma daquelas que já conhece, nem que quem não conheça uma coisa considere que essa coisa esteja entre aquelas que ainda não conhece, e sequer que quem conhece uma coisa creia que seja uma coisa que não conhece: em suma, ou se opina a verdade ou não se opina de todo, excluindo-se a possibilidade de se poder opinar o falso.

Poder-se-ia contornar esta dificuldade dizendo que quem opina o falso não é aquele que não opina de todo, mas aquele que opina aquilo que não é (188cd). Mas essa solução também é impossível, porque ter opiniões ou sensaçôes significa opinar e percepcionar algo que é. Por isso, voltamos ao ponto inicial: quem opina aquilo que não é, simplesmente não opina, razão pela qual, nem deste modo poderá existir uma opinião falsa (189a-b). 
Alternativamente, poderíamos considerar que quem possui uma opinião falsa se encontra na condição de quem troca, no seu pensamento, uma coisa por outra (189d). Porém, posto que pensar equivale a uma espécie de colóquio interior mediante o qual a alma consente com determinadas proposiçóes, nunca acontece que alguém diga para si que o absolutamente belo é feio, ou que o injusto é justo, que o boi é um cavalo, ou que o dois é um (190b-c). Assim, mesmo por esta via, ter uma opinião falsa parece algo impossível. Porém, é um fato inegável que existam opiniōes falsas.

Por essa razão surge uma outra hipótese, ou seja, que a opinião falsa seja causada por um mau funcionamento na conexão entre sensação e conhecimento. Para ilustrar isso, Sócrates introduz a célebre metáfora do bloco de cera: é possível imaginar que as sensações deixem na cera da alma marcas que deixam vestígios, e que o erro nasça quando a alma não consegue combinar tais vestígios com as sensações correspondentes. Sócrates acrescenta que serão mais propícias aos erros aquelas almas cuja cera não for bem temperada, ou por ser muito dura (tornando difícil a aprendizagem), ou por ser muito líquida (propiciando o fácil esquecimento). Tais são as almas dos ignorantes, totalmente opostas às dos sábios (194c-195b). Mas o problema ainda não foi resolvido, porque não há erros só quando conhecimentos e sensações interagem, mas também quando se trata de conhecimentos não sensíveis. Por esse motivo, voltamos à dificuldade inicial; isto é, à dificuldade de entender como é possível um homem 
confundir dois conhecimentos igualmente presentes na sua alma.

Sócrates prossegue dizendo que todas essas dificuldades derivam de um erro básico, ou seja, da pressuposição de saber a priori o que é o conhecimento, quando a natureza do conhecimento é justamente o que se busca. Com o objetivo de explicar a possibilidade da existência da opinião falsa fora introduzida a distinção entre conhecimento e sensação, mas o conhecimento não fora de nenhum modo definido, por isso, todo esse discurso se move em um círculo vicioso.

Para descobrir a natureza do conhecimento, Sócrates introduz uma nova metáfora. Ele compara a posse dos conhecimentos por parte da alma ao aprisionamento de aves em uma gaiola, e ressalta que há diferença entre esse tipo de posse, que é potencial, e a posse efetiva, que se verifica apenas quando um conhecimento é possuído de modo atual. É a diferença que ocorre entre possuir conhecimentos em um estoque e o uso efetivo que deles se faz. De tal maneira, o erro poderia ser explicado aceitando-se a hipótese de que a alma, tentando procurar em seu estoque, entre os conhecimentos que possui, aquele que deseja utilizar, se equivoca e recolhe um ao invés de outro: mais ou menos como, mesmo sabendo bem qual pássaro apanhar dentro da gaiola, acontece que nos caia nas mãos o pássaro errado (199a-b).

Mas, como pode acontecer que dois conhecimentos possam ser trocados um pelo outro? que o matemático, no ato de fazer um cálculo, mesmo possuindo 
na sua alma o conhecimento de todos os números, erre uma soma trocando o onze pelo doze, isto é, confunda uma coisa que conhece com uma outra que também conhece? Aqui faz-se útil a proposta de Teeteto, segundo a qual poderiam existir dentro da gaiola, junto aos conhecimentos, também os não conhecimentos (199e), porque a dificuldade seria sempre a mesma: também o não conhecimento, se está presente na alma-gaiola, é algo conhecido, por isso quem troca um conhecimento por um não conhecimento, troca também e sempre uma coisa que conhece por outra que também conhece. Com isso toda a investigação é lançada em alto mar. A verdade é que não sabemos o que é o conhecimento, e que a definição "opiniāo verdadeira" não pode ser correta.

As razões desse fracasso, não obstante a dificuldade dos argumentos que Platão apresenta, não são tão obscuras. Como já sabemos (ver cap. 7, pp. 82-3), o termo "opinião", em Platão, não significa só "conhecimento relativo ao sensível”, mas também "juízo da alma”, e é justamente essa acepção que é empregada a partir da segunda parte do Teeteto (enquanto na primeira parte era entendido no outro sentido). Essa mudança de significado poderia, por si mesma, nos fazer esperar que a investigação estivesse tendo alguma evolução. É também verdade, contudo, que podemos falar de ciência, ou de conhecimento, somente no caso em que o juízo da alma (ou seja, a opinião nesse novo significado) seja verdadeiro. Mas, então, é necessário supor a existência de um critério de conhecimento, 
útil para separar o verdadeiro do falso, diferente da opinião mesma. Uma vez que esse critério ainda não foi encontrado, a definição de conhecimento como "opiniāo verdadeira"0 revela-se insuficiente.

Esse argumento é abordado a partir do problema do erro. Se a opinião fosse entendida ainda como "conhecimento da realidade sensível", o erro não existiria, porque as opinióes deste tipo são sempre verdadeiras. De fato, na primeira parte do diálogo, Platão não havia negado a Protágoras que cada pessoa tivesse razão ao avaliar suas percepções. $\mathrm{O}$ que ele tinha objetado é que não é a esse tipo de saber (ou seja, a sensação) que deve ser atribuído o título de conhecimento (ou de ciência): de fato, este pode ser apenas atribuído ao conhecimento intelectivo.

Mas o problema do erro é proposto novamente também nesse nível. $\mathrm{O}$ único caso pelo qual se pode explicar como é possível que se cometam erros é aquele em que há uma imperfeita correspondência entre conhecimento sensível e conhecimento intelectivo (imagem do bloco de cera). Nos outros dois casos, ou seja, quando a investigação se desenvolve totalmente no interior da sensação ou totalmente dentro da intelecção, a questão é muito mais difícil. Acabamos de falar do primeiro caso. $\mathrm{O}$ segundo desenvolve o problema seguinte. Se eu conheço com o intelecto uma determinada coisa, sem que as dificuldades inerentes à relatividade da sensação entrem em jogo, como se explica que ainda neste caso possa acontecer que eu erre (imagem da gaiola)? 
Ora, é justamente a possibilidade do erro intelectivo, mostrada aqui, que oferece ao leitor informações úteis para continuar a pesquisa sobre a natureza do conhecimento: se ainda não sabemos o que é o conhecimento, pelo menos sabemos que a definição procurada deve considerar o fato que esse conhecimento não é infalível, exatamente porque pode acontecer que haja uma confusão entre um conteúdo noético e outro.

\section{O TEETETO: O CONHECIMENTO É A OPINIÃO VERDADEIRA QUE ACOMPANHA O LOGOS?}

Para encontrar um critério que garanta e reforce a "verdade" da opinião verdadeira e que permita ao mesmo tempo entender quando e porque uma opinião pode ser falsa, Teeteto propõe uma identificação entre o conhecimento e a opinião verdadeira acompanhada de logos (entendido como raciocínio e discurso). Mas o logos, observa Sócrates, pode ser entendido em três diferentes acepções:

1. "manifestar o próprio pensamento, mediante a voz, com verbos e nomes" (206d).

2. "enumeração dos elementos que compõem uma coisa" (206e-207a).

3. "poder indicar um sinal por meio do qual a coisa que se interroga difere de todas as outras" (208c). 
Porém Sócrates ataca todas as três definições:

1. a primeira, porque manifestar o próprio pensamento mediante a voz é possível a qualquer pessoa mesmo que não possua conhecimento (206d-e).

2. a segunda, porque se a razão for entendida como enumeração de elementos não será nada além de opinião (208b).

3. a terceira, porque a capacidade de distinguir uma coisa de outra é já propriedade da reta opinião, que, caso contrário, não seria reta (208c209e).

Portanto, nem mesmo o logos consegue acrescentar algo de definitivo à opinião, para poder garantir sua verdade. Mas se trata verdadeiramente de um êxito paradoxal e imprevisível, como sustentam muitos intérpretes? Na realidade, não. Contudo, seja como for, o logos é uma forma de raciocínio, que tem o objetivo de reforçar uma determinada avaliação: enquanto a opiniāo verdadeira identifica a situação em que a afirmação " $s$ é $p$ " descreve corretamente o estado dos fatos, o logos é o raciocínio através do qual se demonstra porque as coisas estão de verdade assim.

Agora, é fácil observar que, se o objeto do juízo fosse diretamente perceptível, para compreender que esse juízo é verdadeiro não teríamos necessidade de nenhum raciocínio. Se, ao contrário, o raciocínio é necessário, isso significa que as condições de possibilida- 
de de verificação ou de falseabilidade que enunciamos não estão disponíveis; ou seja, eu não tenho condições para verificar diretamente se o estado de coisas corresponde àquele enunciado no juízo. Isto é exatamente o que acontece na doutrina platônica das ideias. Por esse motivo, de um lado, o raciocínio será necessário, e de outro, cada raciocínio (que possui, contudo, natureza proposicional) será novamente submetido ao juízo da alma, à qual caberá sempre a decisão final de dizer se o raciocínio é verdadeiro ou não. Fica claro que esse juízo não poderá ser infalível.

Eis o que Platão quis mostrar com o Teeteto. A primeira parte certifica (contra Protágoras, mas de maneira geral contra os materialistas, sensistas e relativistas) que o verdadeiro conhecimento possui caráter intelectivo e não sensível. A segunda parte, porém, mostra como esse saber intelectivo não possa e não deva ser entendido como uma correspondência perfeita entre o objeto e suas descrições. O objeto que o pensamento desejaria descrever, de fato, são as ideias, as quais existem em uma dimensão separada e diferente da humana, razão pela qual, tal correspondência permanece, por princípio, inverificável. Esse é o motivo pelo qual o diálogo, no final, não chega a lugar nenhum. Mas justamente esse êxito negativo, à luz das estratégias dialógicas que Platão utiliza nos diálogos aporéticos, tem o efeito de sugerir, por contraste, o modo correto de proceder: se pretendemos ter alguma ideia do que é o conhecimento, pelo menos aquele que é realmente acessível ao homem, é preciso abandonar o modelo 
"forte" da correspondência entre objeto e suas descrições, e adotar aquele mais fraco da coerência das nossas descriçōes entre si: um modelo que será claramente anunciado, como veremos, no Sofista.

\section{O PARMENNIDES: A DOUTRINA \\ DAS IDEIAS COMO SOLUÇÃO ÀS \\ DIFICULDADES DO ELEATISMO}

O Parmênides é um dos diálogos mais enigmáticos de todo o corpus. Platão imagina um debate (claramente fictício, de acordo com a cronologia que conhecemos) que teria acontecido em Atenas entre o jovem Sócrates e um Parmênides, já bastante ancião, na presença de seu discípulo Zenão, também com a participação de um jovem chamado Aristóteles (não confundir com o discípulo de Platão).

Encerrada a apresentação, o diálogo se abre logo após Zenão ter terminado de ler seu livro em público. A discussão inicia a partir de um raciocínio de Zenão: ele tinha sustentado que se existisse a multiplicidade, deveria ser ao mesmo tempo semelhante e diferente, o que é impossível. Zenão não queria tanto demonstrar que a multiplicidade não existe quanto mostrar que os difamadores de Parmênides, defensores da existência da multiplicidade, não tinham nenhum motivo para menosprezá-lo, porque de suas hipóteses provinham consequências não menos absurdas que as obtidas mediante os princípios parmenídicos (128d-e). 
Sócrates replica dizendo que esses problemas poderiam ser resolvidos recorrendo-se às ideias. Não é de se estranhar que os entes físicos tenham contemporaneamente predicados opostos, como unidade e multiplicidade. De fato, as coisas mudam seus atributos por participarem de ideias correspondentes: assim, uma determinada coisa $x$ participa da ideia de $x$ e ao mesmo tempo de outras ideias. É claro que, sobre um mesmo objeto, podem incidir, sob diversos aspectos, predicados opostos. Por outro lado, seria verdadeiramente um prodígio descobrir que a semelhança pode ser também dessemelhança, etc. (129b-130a).

Com essa observação, Sócrates não tem somente a intenção de resolver as contradições provenientes do conhecimento sensível, mas também de abrir um novo campo de investigação relativo às ideias. Posto que a predicação contraditória nas ideias seria um absurdo, Sócrates tenta propor também a possibilidade de instituir entre as ideias um gênero não contraditório de relaçôes: se alguém tomasse as ideias separadamente em si mesmas, e demonstrasse que são tais que podem se misturar e se separar, o espanto de Sócrates não corresponderia mais à incredulidade de quem vê tentada uma coisa impossível, mas à satisfação de quem vê realizada uma coisa realmente maravilhosa (129e). Aqui, a questão implicitamente levantada é a de compreender como devem ser entendidas as ideias para que essas relações de união e separação sejam realmente possíveis. 


\section{A DOUTRINA DAS IDEIAS EM DISCUSSÃO: AS OBJEÇŌES DE PARMÊNIDES}

No diálogo, Platão levanta esses problemas através da intervenção de Parmênides, que formula em rápida sucessão uma série de objeçóes contra a doutrina das ideias, tal qual a entende o Sócrates interlocutor.

Uma primeira observação diz respeito ao problema de entender se existem ideias de todas as coisas (sobre isto, falamos anteriormente no cap. 6, p. 73). Uma vez esgotado esse ponto, Parmênides resume do seguinte modo (com o consenso do seu interlocutor) a doutrina das ideias que Sócrates referiu: as ideias são aquelas coisas das quais participam os objetos que delas trazem o nome, por isso, se diz que são belas as coisas que participam da beleza, grandes aquelas que participam da grandeza, justas aquelas que participam da justiça, e assim por diante (130e-131a).

A primeira crítica deriva diretamente dessa definição. Se a ideia da pequenez é a única coisa da qual participam muitas coisas pequenas, deduzimos que ou a ideia se multiplica para todos os objetos que dela participam, com o resultado que a ideia não seria mais uma (ou estaria separada de si mesma), ou então se dividiria, de modo que cada um dos objetos participaria somente de uma de suas partes. Ambas as coisas são impossíveis, porque a ideia é única por definição (131c-e).

A segunda crítica é a do "terceiro homem" (ver também o cap. 6, pp. 70-1). Se a ideia $x$ (por exemplo, a ideia de homem) é usada para explicar o fato 
que muitas coisas possuam $x$ como característica comum, podemos sempre pensar em um conjunto que compreenda, além dos objetos que possuam a característica $x$, também a mesma ideia $x$, com o resultado que será necessário formular uma segunda ideia capaz de justificar o fato de os objetos qualificados $\operatorname{com} x$ e a ideia $x$ possuírem $x$ como característica comum (132a-b): no exemplo de Aristóteles, devemos supor a existência de um terceiro homem, além do homem concreto e do homem ideal.

Desta primeira parte da discussão, deduz-se que as ideias são pensadas como uma espécie de objetos ou de coisas; e isso vale quer se as entendemos diretamente como objetos que se multiplicam ou se dividem nas coisas sensíveis (ver a primeira crítica), quer se as entendemos como modelos aos quais as coisas assemelham, porque essa relação de semelhança implica o fato de as ideias serem "coisas" providas de determinados atributos. Essa situação permite entender o motivo pelo qual Sócrates, em 132b, formula a hipótese que as ideias existam somente na alma do homem: porque dessa forma ambas as objeções que apresentamos não seriam mais pertinentes.

Mas Parmênides demonstra que também essa hipótese produz consequências absurdas: se a ideia é aquilo que é pensado de maneira única e idêntica, em todas as coisas semelhantes, ou todas as coisas são ao mesmo tempo pensamentos e pensam, ou se deve supor que as coisas que participam das ideias participem do pensamento mesmo sem serem pensamento (132c). Esse difícil argumento depende essencialmente do modo 
pelo qual as ideias são definidas por Sócrates ao longo do diálogo. Se afirmarmos que as coisas participam realmente das ideias, é absurdo sustentar que as ideias existam somente na alma (isto é, que sejam somente pensamentos), porque uma relação de participação entre coisas e pensamentos é impossível (a menos que essas coisas não sejam de alguma forma pensamentos).

Existe afinal uma terceira objeção, de caráter mais geral. Na hipótese de Sócrates, as ideias e as coisas constituem dois mundos diferentes e separados, de modo que serão possíveis somente relações entre coisas e ideias entre elas, mas não entre as coisas e as ideias. Por exemplo, enquanto no mundo das coisas o servo terá a ver com o senhor, no mundo ideal, a relação será entre as ideias correspondentes; do mesmo modo, o conhecimento das ideias será acessível somente ao conhecimento em si, isto é, à ideia do conhecimento: logo, será privilégio de uma coisa que nós não possuímos, porque as ideias não moram connosco (134b). Portanto, o belo, o bem e todas as outras ideias serão incognoscíveis ao homem.

\section{O IMPRESCINDÍVEL NÚCLEO DE VERDADE INERENTE À DOUTRINA DAS IDEIAS}

É, sem dúvida, verdade (como observa Sócrates em uma passagem d'A República 478e-479a) que, para as pessoas comuns, os valores que mostramos anteriormente não possuem uma existência real: elas admitem a existência de coisas belas, boas e justas, mas não a 
existência de uma beleza, de um bem e de uma justiça em si. Todavia, essa posição se revela contraditória. Parmênides nota, de fato, que as ideias, não obstante todas as críticas que ele mesmo levantou, são necessárias para o conhecimento, porque se não existisse o pensamento que raciocina (dianoia), não se saberia para onde ir, não haveria um ponto fixo sobre o qual se apoiar, e seria totalmente destruída a capacidade de discutir dialeticamente, que é justamente relacionar particular e universal, o um e o múltiplo, etc. (135c).

Talvez seja este o trecho mais importante de todo o diálogo. Através das palavras de Parmênides Platão revela que mesmo que de uma certa maneira, a teoria das ideias pareça insustentável, não é possível excluir as exigências pelas quais a teoria foi criada. Essas exigências derivam da natureza da faculdade cognitiva que os homens atualmente possuem (a capacidade de discutir dialeticamente): uma posse que não poderia ser explicada sem supor a existência de unidades universais, de eixos em que o conhecimento se apoia.

Não é por acaso que Parmênides insiste, nesta passagem, sobretudo na existência das ideias separadas e na dificuldade que encontra quem queira persuadir os outros dessa existência. A natureza dessa dificuldade já fornece as indicaçōes para se entender o modo pelo qual a investigação deve se desenvolver. Antes de tudo, consideremos as duas primeiras críticas. O que as tornava possíveis era uma teoria que interpretava os fundamentos estáveis do conhecimento como objetos, ou ingenuamente similares aos objetos físicos ou, 
ainda, entendidos como substratos providos de atributos. Para superar tais críticas, tornar-se-á necessário enfraquecer a caracterização ontológico-objetiva dos fundamentos do conhecimento.

Mas nesta parte do Parmênides encontramos também outras indicaçóes. Pensamos, por exemplo, na observação importante com a qual a discussão se iniciou, isto é, a dupla necessidade de salvaguardar o aspecto ético-socrático da teoria (ou seja, da objetividade de princípios como o bem, o belo, o justo, etc.) e de alargar o máximo possível a atribuição do valor, mesmo em relação a realidades inferiores como a lama e o cabelo. Por fim, através das críticas de Parmênides, lemos também a exigência fundamental de permitir a realização de um percurso que garanta uma certa inteligibilidade das ideias, evitando considerá-las somente como arquétipos separados e transcendentes da realidade mundana.

O que parece conclusivo é que Platão está tentando conservar o núcleo teórico essencial inerente à doutrina das ideias, indicando implicitamente um percurso para reelaborar tal doutrina de modo a tornála impermeável às possíveis objeções (como aquelas levantadas por Parmênides neste diálogo). Esse núcleo central consiste na necessidade de supor a existência de pontos de referências fixos, na falta dos quais, a realidade seria um agregado caótico de contradiçóes. Existe, por um lado, uma imagem ingênua das ideias que não deve ser levada em consideração: a que representa o mundo ideal como uma exposição de substâncias que simplesmente duplicam as sensíveis; e, por 
outro lado, existe um princípio que deve ser salvo, ou seja, aquele pelo qual as ideias são unidades relativas a uma determinada multiplicidade.

Essa redução conserva sobretudo a validade axiológica da doutrina, com base no princípio pitagórico de que o uno e o bem são intercambiáveis e coextensivos. Parece ser mais difícil resolver o problema das relações entre o mundo ideal e mundo sensível, e o da situação de incognoscibilidade total das ideias. Esse êxito condenável se dá pelo fato que ideias e coisas têm sido pensadas como dois âmbitos de objetos separados e totalmente diversos. Mas, substituindo a representação ontológica da ideia por aquela que unifica os dois pólos da dialética uno-múltiplo, se pode dizer que a diferença entre ideias e coisas tenha sido realmente superada? A principio não, até porque não era essa a intenção de Platão: mesmo em presença de uma formulação diferente dos princípios, a filosofia platônica permanece sempre e fortemente dualística e metafísica. Mas é possível pensar em uma possível aproximação e também em uma abertura de parciais possibilidades cognitivas.

Se as ideias são entendidas como unidades relativas a determinadas multiplicidades e não como substâncias duplicadas, surge a possibilidade de interpretar o mundo das ideias como um conjunto relacional tocado pela dialética uno-múltiplo. Certamente, a abertura dessa possibilidade não anuncia a impossível conquista de um saber como visão das ideias em si, mas uma parcial iluminação do cosmos noético a partir das relações de inclusão e exclusão que ligam as ideias 
entre si. Com efeito, tais relações representam modos particulares da relação uno-múltiplo, na medida em que a inclusão de uma ideia em outra corresponde ao caso em que esta última ideia é a unidade relativa de um todo ao qual a primeira pertence.

Logo, se quiséssemos sintetizar o significado de toda esta primeira parte do diálogo, deveríamos dizer que nela se prospecta uma redefinição geral da teoria das ideias nos moldes da dialética uno-múltiplo, extensível quer à relação entre ideia e realidade sensível (como veremos no Timeu), quer à relação das ideias entre si (com a qual se abre uma espiral de luz justamente sobre o mundo ideal).

\section{AS HIPÓTESES SOBRE O UNO E SOBRE O MÚLTIPLO}

A segunda parte do Parmênides é bastante enigmática e gerou desde os tempos mais antigos um verdadeiro enxame de hipóteses e interpretações. Primeiramente, Parmênides mostra a Sócrates que as dificuldades até aqui encontradas dependem da relativa pressa do seu raciocínio, isto é, que pode ser entendida como a doutrina das ideias demasiadamente ingênua e elementar como a que foi colocada em xeque na primeira parte do diálogo. $\mathrm{Na}$ sequência, ele expóe a Sócrates o que acredita ser o procedimento correto $(135 \mathrm{c}-\mathrm{d})$. Este método prevê que cada hipótese deva ser verificada por oito perspectivas diferentes. $\mathrm{O}$ exemplo proposto por Parmênides é a relação uno-múltiplo 
(136a-c). Antes de tudo, é necessário colocar as duas hipóteses fundamentais: 1) se o múltiplo é, e 2) se o múltiplo não é. Em seguida, será necessário examinar quatro sub-hipóteses da hipótese 1 e quatro da 2: se o múltiplo é, é preciso analisar o que deriva do múltiplo em relação a si mesmo (1a) e em relação ao uno (1b); o que deriva do uno em relação a si mesmo (1c); e do uno em relação ao múltiplo (1d). Se, ao contrário, o múltiplo não é, é necessário examinar o que lhe acontece em relação a si mesmo (2a) e em relação ao uno (2b); o que acontece ao uno em relação a si mesmo (2c) e em relação ao múltiplo $(2 \mathrm{~d})$.

Esse procedimento complicado, que formalmente pode ser aplicado a qualquer objeto que se queira analisar, possui a intenção de realizar uma investigação na qual todas as possibilidades sejam examinadas. É o próprio Parmênides quem propõe um exemplo concreto desse exercício dialético, escolhendo como hipótese aquela que era considerada uma doutrina típica do eleatismo: se o uno é. A partir dessa hipótese, Parmênides discute e desenvolve com profundidade variável, oito (ou nove) teses diferentes, seguindo aproximadamente o esquema mostrado há pouco.

Mas não entraremos aqui no mérito dessa difícil investigação; nos contentaremos em dizer algumas coisas sobre o seu possível significado geral. A gama de possíveis interpretações articula-se com base em duas perspectivas fundamentais: na segunda parte do Parmênides, Platão pretende i) promover determinadas instâncias teóricas, quer em forma de pura refutação, quer sob forma de uma proposta filosófica construti- 
va; ii) apresentar um exemplo significativo de "ginástica mental" necessária à dialética.

Essas duas linhas interpretativas não se excluem mutuamente. É claro que a segunda perspectiva - se entendida minimamente de forma fraca - não pode ser refutada, porque pode ser deduzida das próprias palavras de Parmênides. Trata-se, antes, de verificar se a segunda parte do diálogo pode realmente ser entendida somente como uma ginástica mental, ou se contém também algumas indicações construtivas no plano propriamente doutrinal.

A favor dessa hipótese está o fato de que existem análises aprofundadas de alguns conceitos importantes, que não só foram mencionados na primeira parte do diálogo, mas também aparecem no Teeteto e no Sofista. Afora as noçôes mais gerais de unidade e multiplicidade, encontramos também o todo e as partes, movimento e repouso, idêntico e diferente, similar e dissimilar, igual e desigual, etc. Isto é, encontramos uma série de conceitos fundamentais, sobre os quais se pode presumir (principalmente do Sofista) que Platão e seus discípulos da Academia desenvolvessem seu trabalho "dialético".

Acrescente-se o fato que o objeto mesmo da investigação, ou seja, a relação uno-múltiplo, parece mover-se justamente no sentido da transformação das ideias em unidades relacionais como conjecturamos ao comentar a primeira parte do diálogo. $\mathrm{Na}$ parte final do Parmênides demonstra-se que a unidade e a multiplicidade são inseparáveis, razão pela qual uma determinada multiplicidade é sempre relativa a uma determinada unidade, e vice-versa: de tal modo que 
não só a unidade absoluta do ser eleático é impossível e absurda, mas igualmente impossível é defender que a multiplicidade possa ser explicada simplesmente por ser múltipla, ou seja, sem fazer referência à unidade que a funda. Como veremos, Platão retornará a tratar desses temas nos outros diálogos dialéticos (particularmente no Filebo).

\section{QUEM É O SOFISTA? \\ O MÉTODO DICOTÔMICO}

No Sofista, tal como no Político, o condutor do diálogo é o Estrangeiro vindo de Eleia, sobre o qual não se dá qualquer informação. Ele escolhe o jovem Teeteto como seu interlocutor na investigação sobre a natureza do sofista. Antes de enfrentar diretamente o problema, ele sugere a necessidade de escolher o método adequado, testando-o antes de tudo sobre um objeto mais simples: o pescador com linha de pesca.

O método proposto (chamado dicotômico, ou "da divisão") prevê antes de tudo a identificação de uma classe muito abrangente à qual pertença especificamente o objeto em análise; tal classe será, em seguida, dividida em duas subcategorias que esgotam a classe, em uma das quais se encontra o ente procurado; a qual, por sua vez, será novamente subdividida de maneira análoga, e assim sucessivamente, até não dever mais ser dividida, porque corresponde ao objeto da investigação (218d-221c).

Dado que o método é aplicado ao sofista, descobre-se embaraçosamente que este pode ser definido de diversas maneiras, não de uma só. De acordo com a 
primeira definição, o sofista é aquele que caça jovens ricos, com a intenção de obter lucro. Mas pelo fato de na arte dos negócios existir outro aspecto além da caça, qual seja, o comércio e a troca de bens, surgem outras duas possíveis definições: o sofista é um comerciante de saberes úteis para a alma, ou então, de um ponto de vista mais particular, ele é um comerciante varejista da mesma mercadoria, quer a que adquire quer a que ele mesmo produz. Se considerarmos que há também uma parte da aquisição que consiste num combate, o sofista poderia também ser enquadrado nesse gênero, como expert na arte de combater com os discursos, com a finalidade de obter lucros (221c-226e).

Essas primeiras quatro definiçōes são relativas às polêmicas antissofistas presentes em alguns diálogos da juventude (como no Protágoras, no Górgias, no Hipias Maior e no Menor, etc.). Mas agora o objetivo de Platão não é tanto polemizar contra a sofística quanto distinguir a sofística da filosofia praticada por ele e pela sua escola, porque na semelhança formal dos métodos (o discurso refutador e antilógico) essa diferença poderia não aparecer, e sobre essa confusão especulava Isócrates e sua escola, concorrente direto de Platão e da Academia.

Entende-se, assim, porque a quinta definição do sofista parece representar principalmente o tipo ideal e perfeito do filósofo socrático, que pratica a refutação com o objetivo de purificar a alma do interlocutor do seu pretenso (falso) saber (226b-231b). Não é pois um caso que a arte definida desta forma, à qual seria bom todos se submeterem, não seja identificada de bom 
grado pelo Estrangeiro com a sofística. Quando Teeteto afirma que as duas práticas são muito semelhantes, o Estrangeiro replica dizendo que o lobo também assemelha ao cão, tal como o animal selvagem assemelha ao doméstico (231a). A distinção entre sofística e filosofia deve ser tanto mais precisa quanto mais elas, na aparência, se assemelharem; e se assemelham ao ponto que a filosofia em sentido socrático como paideia fundada na refutação pode ser chamada pelo mesmo nome de sofística, embora se perceba que se trata de uma sofística nobre e não de uma vulgar.

\section{O PROBLEMA DO NÃO SER}

A pluralidade de definiçōes encontradas mostra que a natureza do sofista ainda não foi esclarecida. $\mathrm{Na}$ intenção de progredir um pouco mais, Sócrates lembra um dos pontos que emergiram durante a investigação precedente, isto é, que o sofista é um mestre na arte da contradição. Essa capacidade universal de contradizer pressupõe, porém, um saber igualmente universal, porque seria inverossímil que um homem a possuísse realmente. De fato, o sofista pode ser definido como aquele que, privado da verdade, possui uma ciência aparente sobre tudo (233c-d): sua habilidade consiste em imitar e falsificar e é daí que advém seu virtuosismo no contradizer.

A arte da imitação também pode ser dividida em duas subseções: uma é a arte de representar, que consiste em realizar imitações que reflitam fielmente uma 
determinada coisa; a outra é a arte da aparência, que consiste em realizar imitaçóes que reproduzem uma determinada coisa apenas na aparência, sem o fazerem realmente. Se o sofista pertence à segunda dessas duas classes (dado que a primeira qualifica sobretudo as artes figurativas), surge um problema de dificílima solução. A possibilidade que uma coisa pareça algo que não é, assim como, em geral, a possibilidade que existam asserçōes falsas, implica a hipótese de que aquilo que não é seja. Mas essa hipótese contrasta com os princípios estabelecidos pelo eleatismo, segundo os quais é impossível dizer e pensar que o ser não seja (238d-241b).

É introduzido, assim, o problema do ser, do não ser e das suas relaçôes recíprocas. É importante notar que tal problema não é colocado somente para tentar apreender a natureza fugaz do sofista. De fato, na medida em que o não ser coincide com o falso (isso se verifica também na língua grega, na qual se dizia "é" e "não é" para significar "é verdade" e "não é verdade"), a dificuldade de dar uma existência ao não ser também diz respeito à positiva e pedagogicamente eficaz arte refutatória do filósofo socrático. Refutar um interlocutor significa colocá-lo na condição de reconhecer por falso aquilo que antes defendia, e implica, em geral, admitir que existam afirmaçóes capazes de exprimir apenas a aparência de uma coisa. A investigação sobre a natureza do sofista deixa transparecer o escopo real do diálogo, que é precisar as condiçōes, ontológicas e gnoseológicas, necessárias para possibilitar a atividade antilógico-dialética em geral (incluindo a sofística), e a filosófica, em particular. 
No Sofista, portanto, Platão acerta contas com a ascendência eleática presente de forma variada no seu pensamento, e traça com clareza as fronteiras da sua extensão. Esse tema é desenvolvido em particular na segunda parte do diálogo.

\section{O “PARRICÍDIO” DE PARMÊNIDES}

A proibição eleática de pensar e pronunciar o não ser parece, à primeira vista, lógica e natural. Se, com efeito, pronunciamos a expressão "o que não é", devemos entender que isso de que falamos, negando sua existência, não esteja entre as coisas que são. Todavia, só pelo fato de indicá-lo como "alguma coisa" implica que se trata de alguma coisa que é e, por conseguinte, nosso discurso cai em contradição. De maneira geral, devemos reconhecer que ao que não é não pode ser dado nenhum atributo. Mas isso significa que devemos renunciar totalmente a enunciá-lo, porque em qualquer predicação negativa está implícita também uma predicação positiva; assim, quando negamos a existência de um grupo de coisas, de forma implícita também atribuímos a tais coisas uma multiplicidade. Porém, o mesmo discurso com o qual negamos que o não ser seja dizível e cognoscível, precisamente pelo fato de nomear o não ser, também lhe atribui pelo menos a qualidade da unidade, a natureza de ser aquela coisa específica da qual estou falando agora (239a). Portanto, se seguíssemos com rigor os princípios do eleatismo, não restaria nada além do silêncio. 
Então, devemos nos acomodar diante desse resultado falimentar? Talvez sim, se Platão fosse um filósofo apaixonado por certos princípios lógicos absolutos e indiferente aos dados da experiência. Mas o Sofista demonstra que ele jamais aceitaria essa perspectiva. Dado que o princípio lógico de Parmênides é incompatível com a experiência (em primeiro lugar com a cognitiva e a linguística), Platão decide respeitar a experiência e introduzir uma exceção àquele princípio.

Desse modo, realiza-se o famoso "parricídio", mencionado pelo Estrangeiro de Eleia em 241d: é necessário dizer, sem receio, que o que é, em um certo sentido também, não é; e o que não é, de um certo modo também é, senão "nunca se poderá, absolutamente, escapar do ridículo, ao se falar acerca de discursos falsos e de opiniōes falsas, quer sejam imagens, representações, imitações, aparências [...]" (241e).

O que o "parricídio" enuncia é só a tese: agora se faz necessário tomar a tremenda iniciativa de refutar (nos limites necessários de tal ação) o princípio parmenídico. Depois de uma passagem rápida sobre as posições dos pré-socráticos (todas consideradas ineficazes), o Estrangeiro focaliza sua atenção no problema do ser, tomando em consideração as opiniões dos que usam no discurso a expressão "o que é" (243d). Dois pares opostos de teses são examinadas. O primeiro par, classificado com base no critério de número de princípios, distingue pluralistas de monistas. Pluralistas são aqueles que acreditam em uma realidade originariamente múltipla. Por comodidade de análise, 
Platão examina nesse momento só a hipótese que prevê uma dualidade de princípios. A essa dualidade ele objeta que, se ambos os princípios "são", será necessário acrescentar-lhes pelo menos um terceiro princípio, ou seja, o próprio ser. Ainda pior seria se o ser fosse atribuído somente a apenas um dos dois elementos, porque assim não se poderia mais dizer que ambos são (243e-244b).

Igualmente complicada é a posição dos monistas. Se existisse apenas uma única coisa, essa coisa não poderia sequer ser chamada "ente" (porque então teríamos pelo menos duas coisas, ou seja, a própria coisa e o nome "ente") e, de maneira geral, precisaríamos renunciar a qualquer nominação. Mas se, como parece afirmar Parmênides, o todo possui partes, também neste caso não poderia ser uma unidade absoluta (o uno enquanto tal). E, finalmente: o mesmo discurso pelo qual o uno deve ser também inteiro constitui já uma duplicação dos entes; portanto, não será possível dizer que o uno não é inteiro, etc. (244b-245e).

Qual é o resultado dessa análise? Antes de tudo que o ser não pode ser idêntico ao uno, porque, como vimos nas argumentações que expusemos, isso provocaria a perda de todas as características que fazem do ser justamente algo que é. Logo, o ser é originariamente múltiplo e, mesmo que sua essência seja constituída pela unidade, deve, porém, tratar-se de uma unidade que é unidade do múltiplo, o que lhe permite ser enquanto múltiplo, sem o anular em uma síntese maior: ou seja, na existência de uma coisa ou ser único, de 
acordo com o modo pelo qual era normalmente entendido o pensamento eleático.

Esse problema fica explícito na objeção que Platão levanta contra os pluralistas. Não os contesta sobre a multiplicidade dos entes, mas observa que os entes por si mesmos não bastam, porque a lógica do conhecimento e do discurso prevê que junto aos entes também existam classes conceituais nas quais os entes são inseridos e mediante as quais se pode falar deles. Tal, por exemplo, é o ser, razão pela qual, junto aos vários entes (dois, ou quantos quisermos), deve existir alguma coisa em função da qual se pode dizer que todos esses entes "são". Novamente, a evidência do modo humano de conhecer, que se manifesta na linguagem, constringe a investigação a se mover em direção ao universal.

Diferente é o critério que distingue o segundo par de posiçôes. Os que sustentam o primeiro par acreditam que cada coisa é corpo, e que, se uma coisa não pode ser apreendida ou tocada, não existe. Os que defendem o segundo (os "amigos das formas"), por sua vez, acreditam que o verdadeiro ser possui uma natureza invisível e é constituído por ideias inteligíveis e incorpóreas (246a-c). Os materialistas possuem um caráter bem mais violento e intratável; mas se conseguíssemos fazê-los raciocinar com calma, seriam obrigados a admitir que existem pelo menos algumas coisas incorpóreas. Por exemplo, se existe uma alma justa, será necessário reconhecer que ela é justa graças à presença da justiça, e, não sem embaraço, eles pode- 
riam dizer que essa "justiça” é algo corpóreo (247b). Se, por outro lado, existe algo incorpóreo, então será necessário encontrar um elemento comum, que é justamente o ser, motivo pelo qual se diz que "são" tanto as coisas corpóreas quanto as incorpóreas. Para resolver esse problema, o Estrangeiro de Eleia propõe a célebre definição do ser como aquilo que possui algum poder, mesmo que mínimo, para agir ou para sofrer a ação (247e).

Essa definição não pode ser acolhida pelos "amigos das formas". A posição por eles sustentada é uma apresentação da teoria das ideias no seu significado ingênuo e primitivo: as ideias são a realidade verdadeira, invisível e imóvel, por isso elas permanecem livres de qualquer devir e de qualquer relação de ação e paixão. Mas não será justamente esse o motivo pelo qual as ideias, no Parmênides, pareciam impermeáveis a qualquer gênero de conhecimento? Os amigos das formas naturalmente não aceitam essa dedução e consideram, ao contrário, que a alma pode conhecer as ideias. Mas essa forma de contato é por ventura outra coisa senão uma ação, seja ela praticada ou sofrida (248d)? Não é verdade que, se alma é o sujeito do conhecimento, as ideias são os objetos e que, por isso, também as ideias são inseridas na forma geral do ser como potência e movimento, como capazes de sofrer uma ação?

Platão não está retomando seus ataques contra a concepção heraclítica da realidade. Pelo contrário, poucas linhas adiante, o Estrangeiro rebate a conclusão alcançada no Teeteto, que dizia que se todas as 
coisas se movem, não há qualquer possibilidade de conhecimento intelectivo (249b). O que se afirma é que a realidade mais elevada - isto é, as ideias - deve fazer parte pelo menos daquele tipo de devir que consiste na possibilidade de se conhecer a realidade. $\mathrm{O}$ conhecimento intelectual é uma atividade dinâmica, que se desenvolve por meio de operaçóes de união e de divisão, pelas quais se pode também sugerir aquele tipo particular de não ser que é o erro e o falso. Desse modo, entende-se a célebre afirmação do Estrangeiro, segundo a qual é difícil nos convencermos que o que é em sentido absoluto seja privado de movimento, vida, alma e inteligência (249a). Platão quer excluir a hipótese de que o modo de ser das ideias seja igual ao do ser parmenídico, segregado da vida humana e da sua atividade cognitiva; porque "das coisas que são imóveis em nenhuma existe inteligência, de maneira alguma e em nenhum lugar" (249b).

\section{OS CINCO GÊNEROS MÁXIMOS}

A investigação sobre o ser e sobre o não ser chegou a um ponto fixo: o que é não é absolutamente imóvel nem móvel, mas possui de diferentes maneiras essas duas qualidades. O parricídio é uma consequência implícita nessa tese, porque se o ser é móvel, é preciso admitir o não ser que deriva da mudança. Contudo, desse modo, não foram encontrados ainda elementos suficientes para responder à pergunta relativa à possi- 
bilidade de dizer o falso. Uma coisa é o não ser entendido como devir, do ponto de vista ontológico, e outra é o ser entendido como falso, do ponto de vista lógico e semântico. O primeiro desses dois tipos de não ser não apresenta nenhuma dificuldade para Platão, desde que o entendamos como limitado ao mundo material e sensível. Mas o que seria do não ser entendido como falso, que, evidentemente, não pode ser enquadrado nos limites da dimensão sensível?

É claro que esse problema só pode ser colocado no âmbito da investigação semântica sobre o que é o ser e sobre o que significa dizer "é" e "não é" (não sobre a investigação ontológica acerca das características dos entes). Esse tipo de investigação já tinha sido tocado, como se lembrará, quando o Estrangeiro examinou a posição dos filósofos dualistas, perguntando-lhes se o ser era ou não era um outro ente além dos dois que eles admitiram. Agora, a mesma pergunta pode ser dirigida também a quem sustenta a tese sobre a qual o Estrangeiro e Teeteto entraram em acordo: se existem tanto o repouso quanto o movimento (se também do móvel, como do imóvel, se pode dizer que é), o que será então esse ser do qual ambos participam? Seria o ser uma terceira coisa diferente e estranha tanto ao repouso quanto ao movimento (250d)? Segundo o perfil linguístico e semântico, o ser é aquilo que reúne coisas diferentes. Dessa maneira, o problema do ser resulta idêntico ao problema da predicação e da comunhão dos gêneros, na medida em que o ser (a partícula "é") é o que produz tal comunhão. 
$\mathrm{Na}$ linguagem usual, costumamos atribuir a um sujeito (por exemplo, ao homem) numerosos e diversos atributos. Mas poderíamos negar que tal operação seja possível, porque implica que o uno é idêntico ao múltiplo e vice-versa. Mas se assim fosse, as únicas predicações lícitas seriam as tautológicas, do tipo "o homem é o homem" e "o bem é o bem", e jamais se poderia dizer "o homem é bom" (251c). De acordo com essa perspectiva, então, nenhuma predicação é possível; o que significa que nenhum gênero (como o homem ou o bem) mantém relação com outro.

Mas o Estrangeiro demonstra que os mesmos defensores dessa tese são os primeiros a desmenti-la, basta falarem, porque qualquer forma de fazer uso do logos pressupõe a possibilidade de comunhão dos gêneros (não podem, por exemplo, não usar a palavra ser para todas as coisas de que falam). Não menos absurda é a tese contrária, segundo a qual todos os gêneros participam de tudo, porque assim se produziriam as piores contradições: poder-se-ia dizer, por exemplo, que o movimento participa do repouso, etc. Portanto, só nos resta escolher a tese intermediária, segundo a qual existe a participação de alguns gêneros em outros, mas não em todos. Nesse quadro, o ser não deve ser entendido como uma coisa à parte, separada de todos os outros gêneros: mesmo que seja um gênero diferente dos outros, não deixa de estar intimamente ligado a todos os outros, porque todos dele participam (252b-e). Do ponto de vista semântico, o ser é a classe na qual estão inseridas todas as coisas das quais se pode dizer que são. 
Se, portanto, existe uma mistura parcial dos gêneros, existe também uma ciência capaz de descobrir quais são os modos corretos de mistura (tal como existe a arte de encontrar a palavra correta misturando as letras do alfabeto). Essa arte, que é a mais importante de todas, é exercida pelo filósofo, e chama-se dialética (253d). O Estrangeiro esboça a primeira tentativa de investigação sobre os gêneros e suas formas de comunicação, advertindo que esse trabalho não dirá respeito a todos os gêneros, mas somente aos mais importantes, para não deixar incompleto o discurso, na impossibilidade de direcioná-lo a uma conclusão definitiva (254c). Essa impossibilidade deriva do número infinito de gêneros existentes, que estão ligados entre si por relações também infinitas e, assim, nunca inteiramente explicitáveis: isso converge, mais uma vez, à natureza incansável e sempre em progressão indefinida, típica do modo platônico de entender o saber filosófico.

Platão identifica, junto do ser e dos gêneros já mencionados como o movimento e o repouso, outros dois gêneros máximos, ou seja, o idêntico e o diferente, de tal forma que, agora, temos cinco ao todo. Esses gêneros máximos, na nova configuração do mundo ideal como estrutura de gêneros e espécies de extensão variada, inclusivos e exclusivos entre si, são os mais amplos e universais entre os demais gêneros. Uma atenção particular, para resolver o problema do erro e do falso, deve ser posta ao gênero do diferente. Dele, como do idêntico, participam todos os outros gêneros, na medida em que cada gênero é idêntico a si mesmo e diferente de todos os outros. Por exemplo, o 
movimento é idêntico a si mesmo, mas absolutamente diferente do repouso ou do idêntico (256e-257a). Assim, podemos dizer que é idêntico e não idêntico ao mesmo tempo; sem nenhuma contradição, porque o movimento é idêntico por participar do idêntico, e não idêntico por participar do diferente.

A participação de todos os gêneros no diferente é a razão que dá origem à sua relação com o não ser. Assim, pode-se dizer que cada gênero participa do gênero do ser (porque é), mas não é o ser (porque é um gênero diferente do ser). Por isso, todos os gêneros, porque são diferentes do gênero do ser, "não são"; e não são tantas vezes quantas forem as diferenças que os distingam dos outros gêneros. Como consequência, Platão pôde dizer (256e) que, para cada um dos gêneros, o ser é "muito" (no sentido que cada gênero se predica de muitos outros), mas o não ser é infinito (porque infinitos são seus laços de diversidade).

Assim se resolve também o problema do não ser em sentido semântico. Quando dizemos que algo "não é", não se tem a intenção de pensar ou exprimir aquele não ser que é oposto ao ser (o nada em sentido absoluto, que justamente não pode ser pensado nem dito), mas o não ser como diferente, que faz parte do ser sob o mesmo título do idêntico, assim como tudo aquilo que não é o belo faz parte do ser tal como o belo. A tarefa do filósofo dialético é evidentemente a de apreender os laços de participação verdadeiros e reais que existem entre os gêneros, dizendo corretamente o que é e o que não é. 
A identificação do não ser entendido como diferente permite, no encerramento do diálogo, resolver de maneira eficaz o problema do erro e do falso e, portanto, de compreender a natureza do sofista. Se existe um não ser diferente daquilo que é, os falsos discursos, isto é, aqueles que dizem o que não é, não são mais motivo de espanto. Assim, o diálogo pode concluir-se com um resultado positivo: a sofística é uma arte mimética que concerne à técnica de provocar contradiçōes, que imita tendo por base as opiniōes, fazendo malabarismos discursivos na intenção de criar determinadas aparências que, por sua vez, fazem parte da capacidade humana (e não divina) de produzir imagens (268c-d).

\section{A DIALÉTICA}

A segunda parte do Sofista fornece esclarecimentos complementares sobre o projeto teórico que Platão procura executar nos diálogos dialéticos. Não há razões para crer que a natureza metafísica das ideias e a intuição intelectual imediata tenham sido colocadas à parte. Ao contrário, confirma-se a necessidade de o conhecimento intelectual passar pelos logoi, que são o material sobre os quais se desenvolve a dialética. Mas, uma vez estabelecida a natureza relacional do mundo das ideias, abrem-se ao logos as possibilidades de conhecimento proporcionadas pela descoberta das relações e da reinterpretação da relação uno/múltiplo dentro do próprio cosmos noético. 
O método dialético funciona mais ou menos assim: o melhor modo para se conhecer uma ideia seria contemplá-la diretamente em sua pureza, por meio de uma intuição intelectual. Porém, a partir do momento que esse caminho se torna impraticável em função da natureza metafísica das ideias, resta apenas tentar iluminar a natureza da ideia a elucidando as relaçôes, positivas e negativas, que ela mantém com as ideias $b$ e $c$ (limitamo-nos por exemplo só a 3 ideias) e, em seguida, repetindo essa operação também para a ideia $b$ (com $a$ e $c$ ) e a ideia $c$ (com $a$ e $b$ ), conforme o modelo do exercício proposto por Parmênides no diálogo homônimo (ver p. 145).

Nesse caso, o único sinal disponível para verificarmos, na medida do possível, se a pesquisa se move na direção certa ou não, consiste na progressiva coerência ou incoerência das descrições que o exercício dialético consegue oferecer: como antecipamos antes ao falar Teeteto (ver p. 139), tal coerência constitui justamente o único critério de verdade realmente disponível, quando falta o critério de verificação direta da correspondência dessas descrições com o objeto ideal.

É claro que o método dialético, se tal é a sua natureza, será sempre circular. Mas não se trata de um círculo vicioso. A doutrina da reminiscência certifica que os homens conheceram em certo momento as ideias e que conservaram em suas almas alguns resquícios daquilo que puderam conhecer. Esses resquícios são explicitados e reativados justamente pelo exercício dialético, que serve deles como guia que orienta im- 
plicitamente a investigação, dando origem a um saber parcial, aproximado e passível de ser aperfeiçoado.

Eis então esclarecido porque é tão improvável que a dialética tenha substituído, no pensamento de Platão, a doutrina da reminiscência (ver pp. 65-6). Não se trata de dois métodos alternativos para alcançar o conhecimento. É sempre a dialética, e não a doutrina da reminiscência, que tem essa função em Platão. A reminiscência fornece, em primeiro lugar, as pistas dos universais sobre os quais a dialética se exercita (como sabemos pelo Fédon, a noção desses universais possui necessariamente uma origem metafísica); em segundo lugar funciona como condição para o fato que a dialética possa desempenhar essa função com sucesso.

O sucesso completo e definitivo do exercício dialético seria possível, naturalmente, graças ao descobrimento de todas as infinitas relaçōes que ligam cada ideia com todas as outras. Mas se trata de uma tarefa irrealista, exatamente como a de intuir diretamente as ideias: a partir do momento que também ela, de maneira análoga, supõe alcançável pelo homem uma condição na qual a pesquisa se esgotou, o eros (traduzido como desejo de saber) desaparece, os philo-sophoi transformam-se em sophoi (e os homens se transformam em deuses). De fato, Platão torna visível a substancial impossibilidade de pensar realisticamente em uma dialética exaustiva, quer no Parmênides (136c), quer no Sofista (254c) e no Filebo (19a-20a). 
(Página deixada propositadamente em branco) 


\title{
O BEM NO HOMEM E NO COSMOS:
}

\section{O FILEBO E O TIMEU}

O FILEBO: A DIALÉTICA UNO-MÚLTIPLO

\begin{abstract}
Oproblema apresentado no início do Filebo é o de estabelecer "a condição e disposição da alma capaz de oferecer uma vida feliz a todos os homens" (11d). Aqui se confrontam duas posições diferentes: a de Protarco (que herdou a tese de Filebo), segundo o qual o bem seria originado do gozo e do prazer; e a de Sócrates, segundo o qual ele teria origem no conhecimento. Contra a tese de Protarco e de Filebo, Sócrates estrutura o seguinte raciocínio. Obviamente todos os prazeres são prazerosos, porque o prazer é idêntico a si mesmo, mas não é obvio dizer que todos os prazeres sejam bons, porque bem e prazer possuem nomes diversos; para demonstrar que o bem é o prazer, é necessário encontrar uma coisa presen-
\end{abstract}


te em todos os prazeres, tal que os torne bons. Porém, também a tese de Sócrates apresenta uma dificuldade análoga: é necessário dizer o que é aquela coisa que permite que todos os tipos de conhecimento sejam bons.

O problema que se apresenta é o conhecido problema da relação uno-múltiplo: ou seja, o problema de entender o que é que nos permite unificar em um só conceito e mediante uma única denominação as coisas que nos parecem diferentes ou pelo menos possuem nomes diferentes. Fazendo clara menção a uma passagem do Parmênides que já conhecemos (129d), Sócrates descarta a versão deste problema que especula simplesmente sobre a relação todo-partes característica das coisas sensíveis. A verdadeira dificuldade surge quando se fala de unidades como o homem, o boi, o belo ou o bem (15a): devemos observar antes de tudo se é necessário questioná-los, depois se existem verdadeiramente enquanto unidades mesmo sendo privadas de geração ou corrupção (não e difícil admitir que este homem sensível exista como unidade, enquanto é incerto que o homem em geral exista como uma coisa singular), e por fim como deve ser pensada sua relação com as coisas sensíveis.

A analogia com as objeções levantadas no Parmênides contra a doutrina das ideias é evidente. No Sofista fora estabelecido o princípio geral para resolver tais objeçôes: nem mesmo as ideias são absolutamente subtraídas do não ser; ao contrário, existem entre elas complexas relações de inclusão e exclusão tais que estão inseridas de várias maneiras na relação uno-múltiplo, dependendo da sua amplitude relativa. No Filebo, o escopo é estabelecer com maior clareza a natureza de re- 
lação uno-múltiplo; mas sobretudo trata-se de mostrar que essa relação representa o primeiro princípio e entre todos mais geral, porque ativo sem exclusão em tudo aquilo que existe: "a identidade entre o uno e o múltiplo, resultante nos discursos, é a mesma para os discursos que se fazem sempre, já desde um passado distante e também agora [talvez aqui haja uma alusão aos présocráticos, particularmente aos pitagóricos]. Esse fato não começou hoje, mas parece ser uma afeção imortal e sem decadência dos discursos humanos" (15d).

Se a relação uno-múltiplo é natural ao logos humano e se, como sabemos, o homem não tem outro acesso ao saber senão mediante o logos, como deve ele organizar a própria atividade de conhecimento, se quiser se aproximar o máximo possível da verdade? Essa atividade é a dialética, ou seja, a arte dialógica do "trocar discurso", ou seja, de dar razão um ao outro instituindo ligaçóes que vão do uno ao múltiplo e vice-versa. De fato, para Platão, não existe outro modo de usar o logos (discurso e raciocínio ao mesmo tempo) a não ser mostrar, através da persuasão dos outros por meio do diálogo, a presença ou ausência de uma ligação entre uma unidade e uma multiplicidade relativa. Ele quis atribuir a esse procedimento a máxima generalização, e não sem razão, porque seria difícil explicar a maior parte das nossas afirmações sem essa generalização. Como seriam possíveis frases como "esta ação é justa" ou "este livro é vermelho" se não se pressupusesse uma relação entre a unidade do justo ou do vermelho e a multiplicidade das açôes e coisas que participam dessas unidades? 
Em primeiro lugar, ocorre, portanto, entender que a co-presença de unidade e multiplicidade é um fato totalmente natural; em segundo lugar, é necessário tratar tal relação com a máxima delicadeza, para estarmos seguros de tratar o "uno e o múltiplo" de maneira justa. A dificuldade e a importância da arte dialética que aqui se propõem são enfatizadas por Sócrates quando diz que ela é como um dom divino, um fogo cintilante que os deuses doaram aos homens (16c-d). Esse dom nos faz entender que todas as coisas são compostas de limite e de ilimitado: a função da investigação, qualquer que seja o problema sobre o qual se discute, é apreender o limite, isto é, a unidade, de modo preciso e, em seguida, dividindo-o, encontrar todos os subconjuntos que participam de tal unidade. A análise não deve recuar antes de ser completada, nem prosseguir quando não há mais necessidade. Somente quando a numeração se concluiu, pode-se livremente deixar correr a multiplicidade. Para dar um exemplo: só depois de ter encontrado a exata multiplicidade de características que constitui a unidade do prazer, se pode abandonar a investigação, pois tudo o resto não é mais que o conjunto de casos particulares e concretos do prazer assim definido.

A investigação que aqui se prospecta se assemelha muito ao ideal da dialética exaustiva, capaz de indicar todos os nexos de inclusão e exclusão que ligam um conceito a outro, ao qual Platão já havia aludido no Parmênides e no Sofista. Todavia, quem estivesse à espera que a investigação acerca do prazer fosse efetuada 
com base nesse método, ficaria desiludido. Sócrates diz que somente o conhecimento completo de todas as unidades tornaria o homem digno (axios) de qualquer coisa (19b). Mas a réplica de Protarco é importante para que entendamos a intenção de Platão assim como as palavras de Sócrates. De maneira bastante razoável, ele ressalta que se é belo para o sábio conhecer todas as coisas, parece que a segunda navegação seja ao menos conhecer-se a si mesmo (19c).

É uma metáfora que já conhecemos: a segunda navegação é aquela sem vento, mais fadigosa, mas necessária na ausência de um meio melhor. Também a menção ao lema "conhece-te a si mesmo" é significativa; aqui encontramos uma inextricável fusão entre o significado originário da expressão (um convite a conhecer os próprios limites) e o significado introspectivo acrescentado por Sócrates, o qual, em Platão, faz muitas alusões à limitação das capacidades cognitivas do homem. O problema que aqui se coloca é o da relação entre ideal e real, entre modelo perfeito e a sua reprodução empírica. Alcançar um saber exaustivo não é tarefa do homem; todavia, é importante conhecer como tal saber deveria ser, porque somente assim o homem pode orientar sua busca.

\section{LIMITE E ILIMITADO}

A observação sobre os limites do conhecimento humano serve para Protarco convencer Sócrates (na 
impossibilidade de aplicar o método exaustivo descrito por ele) a tentar igualmente apreender a natureza do prazer. Sócrates aceita com satisfação esse convite, admitindo que não há necessidade de dividir o prazer em todas as suas espécies (20c). A premissa geral do discurso é que o bem é "suficiente" (20d): ou seja, o bem é o que os homens desejam por si mesmo, que faz com que as coisas desejadas pareçam atraentes e que, uma vez conseguidas, é como se não faltasse mais nada. Dessa definição, é evidente que o bem engloba a felicidade. Mas nem o prazer nem a inteligência podem ser o bem, porque não são "suficientes" [subentende-se "para a felicidade"]. De fato, por um lado, a consciência do prazer, passado e presente, é essencial para a existência do próprio prazer, mas, por outro, não é atraente uma vida feita somente de inteligência, totalmente privada de emoções e paixôes. Uma vez que, então, nenhuma das duas é "suficiente", só nos resta pensar em um gênero de vida que seja um "misto" de prazer e de inteligência.

Mas atenção: Sócrates tem o cuidado de precisar que as coisas são assim para ele, enquanto para os deuses seriam muito diferentes (22c). Uma vida inteiramente consagrada ao conhecimento e ao saber certamente é uma vida divina, mas os homens não são deuses (como Platão constantemente mostra). Por isso, a vida verdadeiramente boa para o homem, em sua condição mortal, não pode existir sem as bases materiais da experiência no indivíduo e na sociedade. Eis porque Sócrates pode dizer a Protarco que a com- 
petição dos bens é feita para obter o segundo lugar (23d), porque o homem pode no máximo tocar uma felicidade menor do que a dos deuses.

Mas podemos nos perguntar que tipo de relação existe entre prazer e conhecimento e se, por acaso, não é exatamente o conhecimento que torna os prazeres bons (já que, como admitiu Protarco, existem também prazeres que não são bons). Para se responder a esta pergunta, é necessário colocar em questão a natureza do bem. Se, para o homem, a falta de um conhecimento exaustivo significasse também a total ignorância do bem, ele não teria nenhum critério para estabelecer em que consiste a vida boa e a felicidade. Logo, é necessário que exista pelo menos uma pista, com base na qual dirimir a controvérsia entre conhecimento e prazer, para entendermos qual dos dois comanda ou domina o outro (ver 61a).

Platão identifica tal pista no conceito de limite. Ela é a base da doutrina dos quatro gêneros que aparece no Filebo. Recapitulando, na realidade, Sócrates distingue, antes de tudo, dois gêneros: o limite e o ilimitado. O terceiro gênero é um misto dos dois, enquanto o quarto é a causa da mistura (23c-27c). Os especialistas sempre questionaram qual é a relação entre os quatro gêneros do Filebo e os cinco presentes no Sofista, e que relação os primeiros têm com a doutrina das ideias. Mas, desse modo, o problema é mal colocado, porque a análise do Filebo move-se em um nível diferente de generalização. O limite e o ilimitado são, de fato, os princípios e os elementos de tudo aquilo 
que existe, inclusive as ideias. Por esse fato, Sócrates pode dizer que o terceiro gênero (a mistura do limitado e do ilimitado) é o que produz a geração em direção ao ser (26d), porque a existência de cada coisa deriva justamente da introdução de um limite dentro de uma multiplicidade indefinida.

Ao analisar a experiência é possível distinguir aquilo que possui uma natureza de limite daquilo que possui uma natureza ilimitada: a esse segundo gênero pertencem as coisas que podem sofrer variações sem um limite quantitativo, de um jeito ou de outro; ao primeiro gênero pertencem as coisas caracterizadas por uma determinação precisa, como as figuras geométricas. $\mathrm{O}$ prazer, enquanto disponível às variações maiores ou menores, pertence ao gênero do ilimitado (27e). O que Platão quer dizer é que o prazer por si só não possui uma medida, porque tende a se desenvolver de maneira casual e desordenada. O próximo passo consiste em indicar o limite como a causa daquilo que é bom em todas as coisas.

É claro, então, que a descrição dos princípios metafísicos é colorida por um matiz essencialmente teleológico. A presença de um limite torna necessário uma compreensão finalista e "inteligente" da realidade: aquela compreensão que os filósofos da physis não possuíam. É assim explicada a necessidade do quarto gênero, isto é, da causa da mistura. Ela é aquilo que não pertence nem ao gênero do limite nem ao do ilimitado, mas mistura um com o outro com o objetivo de produzir a melhor ordem possível. Que exista uma 
ordem desse tipo é deduzível, por outro lado, da contemplação do cosmos e de suas maravilhosas harmonias. Isso nos induz a pensar que o universo é regulado por uma inteligência ordenadora, de modo que o terceiro gênero parece justamente o do intelecto. Descobrimos, assim, qual é o gênero ao qual pertence o conhecimento: enquanto o prazer pertence ao gênero do ilimitado, o conhecimento pertence ao gênero da causa (31a).

\section{O PRAZER E A FELICIDADE}

Isso não significa que o prazer seja sempre um mal. Já vimos que, para o homem, a vida boa não pode consistir só em conhecimento. Mas, além disso, é possível constatar que no interior dos prazeres, mesmo que o prazer pertença ao gênero do ilimitado, existe diferença entre prazeres mais ou menos puros, e mais em geral, entre prazeres bons e maus. Isso pode ser demonstrado mediante um paralelismo que existe entre o prazer e a opinião: assim como existem falsas opiniôs, devem existir também falsos prazeres (37b-40e). Por isso, o prazer precisa da mediação da alma, para que seja claro que o prazer está sujeito a avaliações, como se evidencia no caso da expectativa: quem possui falsas opiniōes possui também esperanças e falsos temores. Mas esse não é o único caso de falso prazer: pode acontecer que prazeres e dores pareçam mais ou menos fortes, que sejam super ou desvalorizados. 
Muito provavelmente se troca o prazer pela cessação da dor (43d-44a).

O que Platão quer demonstrar é que não se deve considerar prazer, e muito menos verdadeiro bem, aquele prazer que de diversas maneiras está misturado com ou é dependente da dor. O princípio geral que se encontra na base dessa classificação é que o bem de nenhum modo pode ser causa do mal, pelo motivo ainda mais universal que um contrário nunca é causa de outro contrário. No Filebo, em meio à grande variedade de prazeres, Platão pretende isolar a restrita categoria de prazeres puros; isto é, os únicos que podem ser incondicionalmente buscados, porque não dizem respeito a uma falta e não têm qualquer relação com a dor. Esses prazeres dividem-se em prazeres relativos ao corpo e em prazeres relativos à alma, mas têm a característica comum de derivar da contemplação desinteressada: como os prazeres da vista ou da audição relativamente ao corpo e os prazeres que derivam do conhecimento e do saber (50e-51d). Existe aqui uma significativa variação a respeito do modo pelo qual esse tema foi tratado no livro oitavo d'A República, porque no Filebo se admite, de acordo com uma progressiva exigência de mediação, que também os prazeres do corpo podem ser puros.

Esse interesse especial pelo prazer não deve surpreender. O Filebo, de fato, ocupa-se da vida boa, ou feliz, e a felicidade parece ter uma relação importante com o prazer. Por essa razão, a partir do momento que a ética de Platão é governada pelo princípio da felici- 
dade, ele não pode declarar simplesmente que o prazer não possua uma relevância moral (como podem fazer, ao invés, éticas governadas por princípios diferentes da felicidade), nem descartar determinados prazeres apenas porque, em abstrato, não seriam bons: em vez disso, deve mostrar que eles não dão a felicidade. Desse ponto surge a necessidade, para Platão, de analisar o prazer enquanto tal.

Uma vez terminada essa análise, Sócrates passa a discutir também as ciências, dividindo-as em ciências puras, isto é, exatas, e impuras (55c-58e). Mas a posição de Sócrates não é imparcial. Na composição da vida boa entram somente os prazeres puros, enquanto as ciências são acolhidas inteiramente (62c-d). As conclusões alcançadas permitem finalmente resolver a disputa entre conhecimento e prazer, para ver qual dos dois se aproxima mais do bem. Dado que o bem possui as características da beleza, da proporção e da verdade, e que para cada uma dessas características se pode demonstrar a maior afinidade com o conhecimento do que com o prazer, o conhecimento tem então um papel proeminente. Com base nesse critério, é possível também proceder a uma classificação dos bens do ponto de vista do grau (66a-d). O primeiro é a medida exata (de prazer e ciência); em seguida, vem a beleza e a proporção; em terceiro, a inteligência; em quarto são as ciências; e somente em quinto lugar se pode colocar o prazer (e unicamente aquele puro).

$\mathrm{Na}$ complexa construção do Filebo que descrevemos sumariamente, é bem visível o esforço realizado 
por Platão para identificar um ideal realístico de vida boa, à medida das imperfeiçóes da natureza humana, mesmo considerando que o princípio universal segundo o qual o exercício da inteligência - a filosofia - permanece sempre o objetivo mais elevado e mais digno do homem.

\section{O TIMEU: ESTRUTURA FORMAL E CARACTERÍSTICAS GERAIS DO DIÁLOGO}

O Timeu contém aquilo que se poderia chamar a "física" de Platão, na acepção antiga desse termo: isto é, como descrição da realidade sensível e viva, do cosmos ao homem, da sua estrutura e dos seus princípios. Além de Sócrates, os interlocutores do diálogo são o filósofo pitagórico Timeu, o sofista e homem político Crítias, e o general e político siciliano Hermócrates. O Timeu é apresentado como continuação e complemento do programa proposto n'A República. Antes de tudo, Sócrates retoma, na verdade não de maneira muito fiel, o conteúdo do diálogo maior, e, em segui$\mathrm{da}$, anuncia a tarefa que ainda falta desenvolver: fazer ver em sua concretude, dando-lhe vida, aquela cidade ideal que n'A República fora descrita somente de maneira teórica (19b-c).

Crítias toma a palavra, lembrando as antigas lendas, contadas a ele por seu avô homônimo, mas originalmente egípcias, lendas que falavam da antiga civilização ateniense e do mito de Atlântida. É com base nessas histórias, narrando justamente acerca do ótimo 
governo de uma antiguíssima Atenas, que Crítias deveria mostrar a cidade ideal na sua vida efetiva. Mas esse discurso é adiado para um segundo momento (temos a este propósito o Crítias, que infelizmente está muito incompleto), porque é necessário antecipar um discurso mais geral: a descrição da realidade da origem do cosmos até a natureza humana. Desse trabalho se encarrega Timeu, que entre todos os presentes é o mais perito em física e em cosmologia (assim como Crítias era em política).

\section{OS PRINCÍPIOS METAFÍSICOS E METODOLÓGICOS DO DISCURSO DE TIMEU}

Timeu inicia seu discurso fazendo referência à distinção da realidade em dois gêneros $(27 \mathrm{~d}-28 \mathrm{a})$ : o que é sempre, que não foi gerado, e que é percebido pelo intelecto mediante o logos; o que sempre muda, nunca "é" em sentido próprio, porque está sujeito ao nascimento e à morte, e é perceptível apenas por meio dos sentidos, de maneira opinativa e irracional. A partir dessa lembrança, Platão manifesta sua intenção de conservar e confirmar, embora com as atualizações e mudanças introduzidas nos últimos diálogos, a estrutura metafísica exposta nas obras da maturidade: existe uma dimensão perfeita, que possui uma natureza de modelo ideal, enquanto a dimensão sensível possui natureza de cópia, que se assemelha ao modelo nos limites consentidos pela sua conformação material. 
Mas essa relação entre modelo e cópia exige uma intervenção ativa, isto é, exige um sujeito racional que se encarregue de construir a cópia de maneira coforme. Assim fazem as técnicas artesanais, e certamente não é por acaso que Timeu chama o deus de "criador" do cosmos com o nome de "demiurgo", que significa artífice ou artesão. Essa comparação com as técnicas é iluminadora por diversos pontos de vistas. Em primeiro lugar, o demiurgo platônico, diferentemente do deus cristão, não cria a realidade a partir do nada, mas dá forma e estrutura a materiais preexistentes (exatamente como fazem os artesãos). Para se entender bem, em segundo lugar, o que importava sobretudo para Platão na representação da atividade formadora do deus mediante o modelo técnico-artesanal, era refletir necessariamente sobre o fato que o artesão age tendo em vista um determinado fim, isto é, como o objetivo de criar uma boa obra: boa também no sentido que essa palavra possui em grego (e que mutatis mutandis também se conserva no português), ou seja, como útil para alguma coisa, para realizar um objetivo específico.

Portanto, o demiurgo platônico é a "causa" do universo inteiro, no único sentido verdadeiro em que se pode falar de causa: isto é, como o que explica não só quais são as condições que tornam possível um certo fenômeno, mas também porque tal fenômeno aconteceu de um certo modo e não de outro, ou seja, demonstra onde está o fim ou o bem pelo qual as coisas são como são. Platão responde assim, no Timeu, ao pedido adiantado por Sócrates no Fédon (ver cap. 5, 
pp. 57-8), de atribuir o caráter teleológico não apenas só ao mundo do homem, mas ao universo inteiro, mediante a introdução, além do paradigma ideal, de uma inteligência capaz de traduzir o modelo na prática (um tema já presente no Filebo).

Antes de entrar diretamente no tema, Timeu enuncia uma importante premissa metodológica. Partindo do pressuposto que a qualidade de um discurso está sempre ligada à natureza do objeto que este descreve, ele explica que, no que diz respeito à realidade estável e livre de devir, os discursos devem ser estáveis e irrefutáveis, na medida do possível; já no que diz respeito à realidade construída com base nesse modelo, os discursos serão proporcionalmente menos precisos, porque a geração está para o ser como a crença (pistis) está para a verdade. Consequentemente, os ouvintes não devem esperar dele nada mais do que um verossímil (mythos) conto (29b-d).

$\mathrm{Na}$ realidade, a imperfeição do mundo sensível não é a única razão dessa cautela. Como Timeu explicitamente afirma, ela também depende do fato que seu discurso é sempre um discurso produzido por homens, logo, capaz apenas de se aproximar do imóvel e do irrefutável, mas nunca de alcançá-lo inteiramente. $\mathrm{O}$ homem deve se contentar que nada falte àquilo que pode efetivamente fazer (29c). Esse princípio é repetido bem mais adiante, quando Timeu diz que somente deus possui, na medida certa, o conhecimento de como as coisas passam da unidade à multiplicidade e vice-versa, e o poder de realizar tal passagem, en- 
quanto nenhum homem é ou será capaz de fazer nem uma coisa e nem outra (68d). Isso, como sabemos, é totalmente coerente com a distância que existe, para Platão, entre a sophia dos deuses e a philosophia dos homens. No mais, o discurso de Timeu não se refere somente ao cosmos sensível. Ele anuncia que falará dos deuses e da origem do universo e, exatamente sobre tais argumentos, adverte que não poderá ser totalmente preciso e coerente: aqui, obviamente, a escassa inteligibilidade da matéria não é pertinente.

Mesmo dentro desses limites, Timeu se empenha em fornecer uma explicação causal e genética de tudo aquilo que existe, na qual seja mostrada na prática o princípio do bom e do ótimo. Quem espera que esse trabalho seja realizado com a mediação da ideia ficará desiludido: no Timeu as referências às ideias não ultrapassam os princípios mais gerais. O Timeu, de fato, pressupõe o trabalho desenvolvido nos diálogos dialéticos e, em particular, a redução da doutrina das ideias a uma modalidade expressiva de uma doutrina mais geral dos princípios, em que o elemento determinante é a relação uno-múltiplo, limite-ilimitado, etc. Tal redução forneceu a Platão um esquema para traduzir de modo representativo a alegada bondade e perfeição do mundo ideal. Esse esquema possui a vantagem de poder ser aplicado também à realidade perceptível pelos sentidos. Por exemplo, se é verdade que nenhum movimento é igual à imobilidade, um movimento regular e ordenado como o dos astros será mais belo e bom que qualquer movimento casual, visto que é mais 
similar ao que é imóvel e uno. É, portanto, o princípio da ordem matemática o principal critério (mesmo que não seja o único) que guia o discurso de Timeu.

\section{A CRIAÇÃO DO MUNDO: A ALMA, O TEMPO, OS DEUSES}

Sendo bom, e, portanto, querendo fazer o bem (29d-e), o demiurgo fez, antes de tudo, com que a desordem se transformasse em ordem, porque esta é absolutamente melhor que aquela. Em seguida, avaliando que tudo aquilo que tem vida é mais perfeito do que aquilo que não a possui, estabeleceu que o mundo deveria ser como um organismo vivo, munido de alma e de intelecto (30c). Já que, além do mais, o todo é melhor que as partes, o demiurgo tomou como modelo para o seu vivente cósmico o vivente ideal que traz consigo todas as formas vivas, de modo que também o mundo é um único vivente visível que tem dentro de si todos os seres vivos. Que o mundo seja um só, conclui-se por um simples raciocínio lógico. Se fosse mais de um, os vários mundos seriam de toda forma pensados como partes de um conjunto maior e, dessa forma, o mundo permaneceria sempre uno (31a-b).

O mundo, tendo sido gerado, é sensível. Mas aquilo que é sensível deve possuir tanto a terra (isto é, o elemento sólido, que o torna perceptível ao tato) quanto o fogo (que permite a visibilidade). Os outros dois elementos são deduzidos pela exigência de estabelecer 
entre os dois primeiros uma perfeita proporção matemática. Trata-se, naturalmente, do ar e da água. O cosmos contém a totalidade desses quatro elementos, de modo que nada existe fora dele: particularmente nada que possa corrompê-lo, como acontece com todos os outros corpos, que sofrem com a ação do calor, do frio, etc. Assim, o mundo é imune a doenças e à velhice. Sempre atento àquilo que é melhor, o demiurgo fez o cosmos sob a forma esférica, que em meio a tantas outras, é a mais perfeita; e o gerou de modo que não lhe faltasse nada (sendo a auto-suficiência mais bela e melhor do que a necessidade), portanto, fê-lo por fora perfeitamente liso, sem braços nem pernas. No que diz respeito ao movimento, também nesse caso lhe atribuiu o melhor, ou seja, o circular, que entre tantos é o mais similar à inteligência e à sabedoria (34a).

A necessidade obstinada de seu discurso conduz Timeu a postular uma alma também para o mundo; porque o mundo deve ser um vivente, e não existe vida sem o seu princípio, que é justamente a alma. A alma do mundo é construída pelo demiurgo pela mistura de três essências, isto é, o ser, o idêntico e o diverso (35a). Timeu descreve essa mistura mediante um procedimento matemático muito complexo, que não aprofundaremos, contentando-nos em destacar o princípio geral que está em sua base. A alma deve ser uma atenta mistura de idêntico e de diverso, porque deve cumprir a dupla função de se colocar como ponto intermediário entre a realidade visível e a invisível, permitindo uma comunicação do ponto de vista cognitivo entre uma e a outra. 
Mas qual é a relação entre a alma e o idêntico, entre o eterno e o imóvel? Para responder a esta pergunta devemos ter em consideração a concepção do tempo exposta por Platão no Timeu. Diz Timeu que o demiurgo, logo após ter gerado o cosmos e tê-lo visto vivo e em movimento, pensou em fazê-lo ainda mais similar ao vivente eterno. Todavia o mundo, na condição de gerado, não podia ser eterno de maneira perfeita. Por isso, o demiurgo decidiu criar o tempo como uma imagem móvel da eternidade (37d-e).

A dificuldade dessa passagem depende do fato que Platão sente muita dificuldade em encontrar as palavras adequadas para distinguir aquilo que é eterno, porque dura sempre, daquilo que é eterno, porque está fora do tempo. Tal distinção é ofuscada nas duas espécies de eterno de que fala Timeu, uma que permanece em si mesma una (é a intemporalidade), e uma que procede segundo o número, ou a multiplicidade (a eternidade como duração). Essa diferença é explicada algumas linhas depois, onde Platão, fazendo uma alusão justamente às dificuldades da linguagem, afirma que as formas geradas pelo tempo como o "era" e o "será" são muitas vezes referidas erroneamente à realidade "eterna", da qual, pelo contrário, se deve dizer apenas e sempre que é; enquanto o "era" e o "será" podem ser usadas, rigorosamente falando, apenas para falar das coisas que são geradas no tempo (37e-38a).

Com relação ao tempo, temos, portanto, em síntese, três modos de ser: 1) uma existência eterna fora do tempo (o eterno que permanece em si mesmo uno); 2) uma existência eterna no tempo (o eterno que se move 
segundo o número); 3) uma existência não eterna no tempo, no sentido do nascer e do perecer. Enquanto ao primeiro e ao terceiro modo de ser correspondem, respectivamente, a realidade inteligível e a realidade sensível, que realidade corresponde ao segundo? Sem dúvida, ao mundo integralmente compreendido. Mas o mundo pode ser dito eterno somente na medida em que está em movimento e é vivo, porque somente nesse caso pode ser caracterizado por um proceder segundo o número. Por outro lado, para Platão, a alma é o princípio de movimento e de vida. Movimento e vida representam ambos o devir e o transcorrer, o primeiro do ponto de vista cósmico e geral, o segundo especialmente no que se refere àquele transcorrer que é o tempo da consciência, os estados da alma ligados entre si pela memória.

Por isso, podemos dizer que o modo de ser do eterno segundo o número, ou seja, da duração temporal que não tem início nem fim, é o modo de ser da alma por excelência, e que se torna atributo do mundo somente na medida em que o mundo é parte integrante daquele movimento e daquela vida eterna da qual a alma é portadora (esta hipótese, como veremos, é confirmada pelo livro dez das Leis).

Se a interpretação do tempo que expusemos agora é correta, é possível resolver de modo plausível dois problemas que atormentaram os estudiosos por muito tempo. A doutrina da geração da alma no Timeu, em primeiro lugar, parece contradizer o que Platão afirma em outros diálogos, ou seja, que a alma não nasce e nem morre. Ora, a contradição poderia desaparecer se 
admitíssemos a existência de dois diversos modos de eternidade e de geração. A alma não pertence ao grupo das coisas materiais, que nascem e morrem, porque é eterna no tempo. Todavia, é possível dizer, de um ponto de vista metafísico, que é gerada, pois não é eterna da mesma maneira que são eternas as ideias inteligíveis, que estão fora do tempo, mas é gerada junto com o tempo. $\mathrm{O}$ mundo, o tempo e a alma são eternos no sentido que duram sempre, mas a respeito de seu ser dependem metafisicamente do modelo inteligível e da inteligência divina, que existem fora do tempo e que são responsáveis por sua existência e conservação.

Depois de ter criado a alma e o tempo, o demiurgo forma os planetas, que são sinais do tempo, e com eles o sol e a lua, a noite e o dia (38c). Em seguida, é a vez das formas vivas, que já estão distinguidas em quatro gêneros no modelo ideal: em primeiro lugar, os deuses, depois, por ordem, as espécies que vivem no ar, na água e na terra. A respeito dos deuses, Timeu distingue duas espécies: a primeira, realizada no fogo, que corresponde aos astros; a segunda, que corresponde aos deuses da mitologia tradicional (39e-41b). A teologia astral é um tema que Platão, junto com sua escola, desenvolverá cada vez mais na última parte da sua vida e reflete a exigência de dar à religião uma estrutura filosófica e racional. O que podemos e devemos dizer com certeza com relação aos deuses, como se conclui do Timeu, é que são bons e cuidam da parte do mundo que lhes é confiada de modo a torná-la melhor o máximo possível. 
Isso vale, sobretudo, para o demiurgo; em seguida, para os deuses astrais e para os olímpicos, aos quais é confiada a geração dos seres mortais. Enquanto o demiurgo se encarrega de gerar as almas individuais, os deuses criados se ocuparão dos corpos, fazendo com que os seres mortais sejam bons e belos na medida em que lhes consente sua mortalidade (41c-42a). $\mathrm{O}$ material para esta criação é oferecido pelos quatro elementos tradicionais: água, ar, terra e fogo. Em relação ao corpo humano especificamente, nessa parte do diálogo, faz-se referência apenas aos sentidos da visão e da audição (45a-47e). É importante, sobretudo, o primeiro, porque é justamente da visão que nasce nos homens o impulso à contemplação e à filosofia: é mencionado particularmente o efeito educativo produzido na alma pela astronomia, se entendida no modo puramente teórico já descrito n’A República.

\section{A CAUSA NECESSÁRIA, OU CHORA}

No final da primeira parte do diálogo, porém, Timeu observa que as causas da geração do cosmos ainda não foram completamente identificadas. Até o momento, de fato, foram expostas somente as obras produzidas pela inteligência, enquanto agora é preciso completar o discurso com aquelas produzidas pela necessidade (47e-48a). A geração do cosmos se deve a uma combinação entre inteligência e necessidade, na qual a inteligência domina a necessidade, como que a 
persuadindo, a proceder em direção ao melhor. Assim, o raciocínio é obrigado, de certa forma, a retornar ao início, mostrando como no nascimento do mundo era ativa também a origem até o momento não mencionada.

Não é difícil entender o motivo pelo qual Platão sente a necessidade de introduzir essa origem ulterior. Sabemos que o demiurgo é bom e que, ao construir o mundo, se inspirou no melhor e mais perfeito modelo. Todavia, sua obra sofre de importantes limitaçôes, a partir do momento que a cópia não pode por natureza ser idêntica ao seu modelo. Na obra do artesão existe ainda um componente de esforço, um empenhamento constante em superar uma resistência que deve ser de alguma forma vencida, porque por si só não possui as características do bom e do melhor que nela se deseja introduzir.

Tal esforço é aquele que Timeu, nessa passagem do diálogo, não por acaso, chama "persuasão" (48a), porque tem parentesco estreito com os processos de formação psicológica e moral algumas vezes descritos em outros diálogos: pensemos, por exemplo, no cavalo rebelde do Fedro, que deve ser persuadido à moderação, ou à parte concupiscível da alma n'A República, que deve se submeter à razão e acomodar-se à temperança. No Timeu, tal tema é estudado sob o ponto de vista da estrutura geral do universo. A "causa necessária” é a responsável pela resistência e, por conseguinte, pelas restrições que limitam a obra do demiurgo.

Não é fácil delinear uma imagem clara do princípio que é introduzido aqui. Não por acaso Platão 
aconselha a propósito a mesma cautela crítica que havia anteposto ao discurso de Timeu: a propósito dos princípios de todas as coisas, é necessário se satisfazer com um raciocínio provável (48d). A primeira representação que podemos fazer da causa necessária (ou "errante") é a de uma matéria primordial, anterior à diferenciação em quatro elementos (48b). Uma vez que os quatro elementos se encontram em contínuo movimento e contínua transformação um no outro, o mesmo acontece com todas as matérias em que parcialmente se solidifica o fluxo eterno da matéria, seria um erro afirmar que as matérias são determinadamente uma certa coisa. Elas não são um "isto", mas um "tal”, isto é, um modo de ser momentâneo e transitório no qual se apresenta a substância móvel e disforme de que elas são feitas (49d-e).

Mas, se parássemos o discurso nesse ponto, não seria nem preciso nem completo. Com imagens propositadamente vagas, Timeu define a causa necessária como "receptáculo de tudo aquilo que é gerado, tipo uma ama" (49a). Do mesmo mundo da procriação, ele retira também uma representação muito mais vívida e eficaz. Se o modelo é o pai, e a realidade sensível que foi gerada é o filho, a causa necessária é a mãe, que antigamente na relação de procriação era exatamente considerada a matéria ou o lugar em que se imprime o sinal distintivo da forma e do limite, produzido pelo pai (50d).

Portanto, a causa necessária não é só aquilo de que as coisas são feitas, mas, sobretudo, aquilo em que são 
feitas. Por isso Platão a chama também de chora uma palavra que significa, em primeiro lugar, região, depois, por extensão, lugar e espaço. A chora é, portanto, aquilo que determina a materialidade e a espacialidade das coisas, a sua existência em um mundo perceptível e sujeito a geração. Para cumprir essa tarefa, é claro que deve ser, enquanto tal, uma matéria privada de qualquer forma e um espaço privado de qualquer linha ou limite que lhe determine a figura: de fato, deve estar disposto a assumir qualquer forma e a se transformar em qualquer figura (50d). Essas formas e figuras são precisamente materializações temporárias da matéria, linhas que podem ser infinitamente apagadas e reescritas no espaço, e que, como tais, não se pode dizer que efetivamente "sejam". De tal modo, Platão esclarece do ponto de vista metafísico a natureza das coisas sensíveis, cuja característica é justamente não a do ser (reservada aos princípios), mas a heraclítica do devir. O que não muda é, de um lado, a forma (que aparece também nas coisas sensíveis) e, do outro, o receptáculo ou lugar indefinido no qual as coisas continuamente aparecem, como características não substanciais e não independentes daquele substrato.

De um ponto de vista mais geral, a chora representa o extremo resquício de realidade, sitiado além dos limites daquilo que é formal, bom e ordenado. É o caótico, o casual, o ininteligível. Mas, estando assim as coisas, é possível dizer que é um modo da realidade? Este é um problema difícil e controverso. Para tentarmos entender um pouco melhor, devemos distinguir 
dois diferentes pontos de vista, ambos presentes no $T i$ meu. De um ponto de vista mundano, a chora, ou seja, a condição material e espacial onde as coisas se geram e acontecem, é o que faz com que as coisas justamente sejam algo e não um nada, já que nós dizemos que o que não é em nenhum lugar e que não ocupa nenhum espaço, nem na terra nem no céu, não existe de maneira nenhuma (52b). Mas, se considerarmos que, para Platão, a verdadeira realidade é a inteligível, isto é, as ideias, e que a chora representa precisamente a diferença existente entre ideias e coisas correspondentes, ou melhor, entre o que é "acrescentado" às ideias quando elas entram no processo de geração para produzirem as coisas, então ela dificilmente pode não parecer uma forma de não ser.

Isto não significa que, para Platão, a chora seja um princípio cósmico e metafísico do nada o do mal separado da realidade da qual é princípio. Sem dúvida, falar de "princípio negativo" não seria coerente com o andamento geral da metafísica platônica, razão pela qual são princípios somente as realidades superiores, sobretudo sob o ponto de vista dos valores. A chora representa o aspecto material e inconstante da realidade sensível, mas é claro que não existe em si e por si, na medida em que nada é pura matéria, puro espaço e puro devir. Por mais baixo que seja o grau de organização da matéria, nela é sempre reconhecível uma certa forma, uma certa permanência parcial: caso contrário, não haverá nada. Se, por isso, a chora é não ser, sê-lo-á no sentido que é limite do ser além do qual não existe nada, não no sentido de um principio mau e negativo. 


\section{A ORGANIZAÇÃO DA MATÉRIA: \\ OS QUATRO ELEMENTOS E O "ATOMISMO" PLATÔNICO}

Pelo que dissemos, é claro que as matérias-primas terra, água, ar e fogo já dispóem de forma e de inteligibilidade. De fato, explica Timeu que o demiurgo as modelou mediante formas e números, com o objetivo de fazê-las o mais belas e boas possível, trazendo-as de uma condição que era completamente diferente (53b). A menção aos números e, em termos gerais, à matemática, é apropriada à mentalidade do pitagórico Timeu, mas, como já bem sabemos, ela tem a intenção de introduzir o ponto de vista finalista e o domínio do bem.

Para mostrar que a ação providencial do demiurgo estende-se o máximo possível também dentro da matéria, Timeu elabora uma teoria atomística de índole geométrica, mediante a qual a inteligibilidade própria das matemáticas e a bondade que resulta dela afetam também a estrutura íntima da realidade sensível. Visto que os corpos possuem uma profundidade, eles devem ser compostos de superfícies. Tais superfícies são triângulos elementares, isósceles ou escalenos, e é justamente mediante a diversa composição de tais triângulos que o demiurgo deu origem às figuras geométricas sólidas (53c-55d).

As primeiras e mais simples dessas figuras são o tetraedro, o octaedro, o icosaedro e o cubo. A esses quatro sólidos correspondem as quatro matérias-primas. Já que tais matérias possuem diferentes graus de mobilidade e de peso, ao elemento mais móvel e leve cor- 
responderá o sólido mais instável, porque é provido do menor número de bases. Por isso, a estrutura atômica do fogo, a mais flexível entre todas as matérias, será representada pelo tetraedro (isto é, pela pirâmide) e, aplicando-se o mesmo princípio, encontrar-se-á o ar gerado pelo octaedro, a água pelo icosaedro, e a terra pelo cubo (que representa justamente a figura geométrica sólida mais estável, tal como é a terra entre todos os elementos). O conjunto dos sólidos regulares é completado por uma quinta figura, o dodecaedro que, no Timeu, não corresponde a nenhum elemento: Timeu explica que o demiurgo a teria usado para decorar o universo (55c). É provavelmente a partir dessa motivação que os filósofos e astrônomos da primeira Academia (particularmente Aristóteles) elaboram a definição do éter, ou da quinta-essência, isto é, da matéria de que seriam feitos os corpos celestes.

À luz dessa doutrina é possível considerar resolvido o problema levantado por Parmênides, no diálogo homônimo, quando ele solicitou ao jovem Sócrates que considerasse com menor desprezo entes de pouco valor como a lama e a sujeira (ver cap. 6, p. 73): a lama e a sujeira são formas de ser do elemento terra, o qual, por sua vez, é composto de pequeníssimos cubos, isto é, de uma daquelas figuras geométricas que Timeu chama "corpos belíssimos" (53e). Dessa maneira, também a lama e a sujeira, compativelmente com sua natureza, entram no grupo das coisas boas e belas, sem que por isso seja necessário postular, de modo ridículo, para essas duas realidades, um modelo perfeito e inteligível. 
A doutrina dos elementos exposta no Timeu sugere uma relação como o atomismo e, em particular, com Demócrito, um contemporâneo que Platão surpreendentemente nunca cita. Esse silêncio talvez esconda o desejo de calar da maneira mais completa possível uma posição que Platão considerava particularmente estranha. De fato, o "atomismo" platônico parece ter sido construído justamente para se opor ao atomismo democrítico. A teoria dos triângulos elementares e dos sólidos conserva e racionaliza o que, para Platão, era o aspecto mais interessante do atomismo: sua capacidade de explicar, mediante o duplo processo de agregação e desagregação, a incessante mutação dos corpos uns nos outros.

A vantagem da posição platônica consiste no fato que a mutação é agora inteligível e transparente mediante o procedimento geométrico da composição e descomposição das figuras sólidas em figuras planas e vice-versa, enquanto que Demócrito tinha sido obrigado a falar de protuberâncias e de ganchos. Mas o significado desta diferença ultrapassa seu valor puramente explicativo. Para Platão, a inteligibilidade necessariamente chama a si a inteligência, e esta, por sua vez, está ligada a um projeto providencial, voltado à produção da beleza e da bondade das coisas: um projeto limitado, no máximo, pelo caos vinculante do elemento primordial. Bem diferentes são as coisas para Demócrito. Para o antigo atomista, a substância das coisas é a matéria opaca, que se move de maneira totalmente casual, sem precisar de um motivo inteligente subjacente ou que a guie. 


\section{A "FÍSICA" DO TIMEU: O HOMEM}

Uma vez definida a natureza dos elementos, o resto do diálogo contém a "física" platônica propriamente dita, ou seja, a descrição dos vários modos pelos quais o demiurgo e os deuses criados dispuseram e organizaram, no seu todo, as matérias na realidade natural, com particular atenção ao homem, às suas funções vitais e fisiológicas. Desta parte, cujo interesse é frequentemente mais histórico-documental do que propriamente filosófico, lembraremos somente de alguns temas relevantes.

Em primeiro lugar, notáveis são os aprofundamentos da doutrina da alma que aqui se expóem, das quais já falamos precedentemente (cap. 8, pp. 92-3). Mas, no Timeu, Platão manifesta também um interesse novo pelas funções vitais que dela dependem. Encontramos, assim, neste diálogo, uma descrição da natureza dos órgãos e de suas atividades, junto com teorias rudimentares sobre a circulação, a respiração, a nutrição. Enfim, também são indicadas as causas do crescimento, da juventude e da velhice (70a-80d). No que diz respeito à morte, ela é descrita como um afrouxamento dos triângulos da medula, que deixam a alma livre de fugir. Esse processo é indolor, porque nada que ocorre por natureza pode ser doloroso (81e).

As últimas páginas do Timeu são dedicadas às doenças do corpo e da alma, às causas pelas quais se geram e aos modos como podem ser curadas. No que diz respeito às doenças da alma (sobre as do corpo não detalharemos), Timeu explica, em primeiro lugar, que 
derivam da falta de bom senso, a qual pode ser entendida como loucura ou ignorância (86b). Toda a análise que se segue é determinada pelo princípio socrático segundo o qual ninguém faz o mal voluntariamente, mas agora o princípio é questionado, pelo menos parcialmente, por um ponto de vista novo.

Já n'A República Platão tinha mostrado que o bemestar moral e psíquico não deriva somente de uma correta educação da alma, mas também de um calculado equilíbrio na relação entre alma e corpo. Agora, esse tema é ulteriormente aprofundado no quadro daquela aproximação entre corpo e alma (tal como entre mundo físico e mundo metafísico) típica do já maduro Platão. Timeu observa, por exemplo, que, se o corpo possui uma natureza muito excitável, pode causar notáveis distúrbios à alma, ao ponto de fazer crer que certas pessoas seriam más, quando, pelo contrário, não têm nenhuma culpa (87b). A mesma coisa acontece se não existe uma proporção entre o corpo e a alma: por exemplo, se a alma possui uma vitalidade excessiva em relação ao corpo que habita, ela o agita e o enche de doenças; se, ao contrário, um corpo grande e forte está ligado a uma alma pequena e fraca intelectualmente, a alma se corrompe tornando-se obtusa e demora a aprender. O modo para evitar essas doenças consiste em produzir uma equilibrada harmonia entre alma e corpo, exercitando-os com moderação: a medida, de fato, é por excelência o sinal do bem.

Já sancionada n'A República, a importância da educação é também reforçada. Mas, no Timeu, Platão prossegue até dizer, em coerência com o princípio 
socrático da involuntariedade do mal, que a responsabilidade pela maldade dos homens é sobretudo dos pais e educadores, que não souberam formar os jovens adequadamente: ou seja, não souberam endereçar a tendência natural de cada pessoa à felicidade, em direção àquilo que é o verdadeiro bem e que realmente torna o homem feliz. Para Platão, esse objetivo se realiza fazendo com que na alma humana prevaleça a parte racional sobre todas as outras partes, porque ela é a única parte realmente divina e capaz de pensar coisas imortais (lembremos que ela está em contato com a esfera do idêntico): obviamente, na medida em que o homem possa participar daquilo que é imortal (90c). 


\section{O ÚLTIMO PENSAMENTO POLÍTICO DE PLATÃO: O POLITICO E AS LEIS}

PROCURANDO O VERDADEIRO POLÍTICO: O MITO DA ÉPOCA DE CRONO NO POLÍTICO

\footnotetext{
Gormalmente falando, o Político apresenta-se como a continuação do Sofista. As personagens são as mesmas (a única diferença é que o jovem homônimo de Sócrates substitui Teeteto no papel de interlocutor do Estrangeiro de Eleia), e a intenção é prosseguir o mesmo programa então anunciado: descrever (depois do sofista e antes do filósofo) a natureza do político. Idêntico é também o método de pesquisa, ou o procedimento da divisão. Tal procedimento, por sua vez, possui o íntimo e explícito parentesco com a dialética do Filebo: ou seja, com a arte de colocar em relação uno e multiplicidade, dividindo os conjuntos complexos no modo mais aten-
} 
to e preciso possível para evitar os erros, até o ponto em que possa resultar a unidade da coisa procurada (258c, 262c).

Depois de uma primeira divisão, chega-se à definição do político como um homem que possui uma ciência teórica dirigente, não depende de outros, é responsável pela nutrição e cuidado dos homens. O político, em outras palavras, seria uma espécie de pastor de homens (267b-c). Trata-se de uma definição bastante tradicional e, portanto, já logo de início insatisfatória. De fato, o Estrangeiro julga rapidamente a conclusão alcançada como defeituosa. Porque, se realmente se define o político como aquele que nutre, cria e educa os homens, podem vir a ser chamados políticos também os comerciantes, os médicos, os pasteleiros, os professores de ginástica, etc. Aliás, tais pessoas pretenderão ser políticos propriamente ditos, na medida em que também têm a tarefa de criar e nutrir (268c-d).

$\mathrm{Na}$ intenção de ajustar a mira e encontrar a definição justa, o Estrangeiro introduz um grande mito cósmico-histórico sobre as eras do mundo. Esse mito prevê a alternância de um ciclo direto e de um inverso, o primeiro vigora durante o governo de Crono, e o segundo durante o tempo em que a divindade retirou sua assistência do mundo, limitando-se a observar o desenrolar dos fatos. A era em que vivemos atualmente corresponde ao segundo momento: isto é, aquele em que os homens tentam manter no mundo, no limite de um inevitável processo de decadência, a ordem que foi produzida pelo governo do deus. A 
época de Crono, por sua vez, representa uma espécie de era dourada, na qual o tempo corre ao contrário, os homens nascem da terra e rejuvenescem em vez de envelhecerem (268d-274a).

A definição do político como "pastor de homens" é adequada para apreender o papel do político num tempo em que reina a divindade, mas não permite saber quem é o político no tempo e geração atuais (274e-275a). Platão quer dizer que o político é um homem que deve governar outros homens e que, por isso, sua função não é comparável nem com a de um deus, que reina sobre outros homens, nem com a de um pastor que controla um rebanho, porque em ambos os casos trata-se de relaçóes entre sujeitos que estão em dois planos diferentes. Esse argumento pode ser encontrado no livro quarto das Leis, onde é esboçada também uma história da era de Crono que possui algumas analogias com o conto descrito no Politico. Assim como os homens não delegam a bois a chefia do gado, da mesma maneira, Crono delegou para o governo dos homens não homens, mas demônios de estirpe divina e superior (713d). Mas justamente isso é o que acontece na mítica era de Crono e não no tempo dos homens atuais e concretos.

Assim entende-se porque, se o político fosse um pastor de homens, seu papel poderia ser reivindicado por médicos e professores de ginástica. De fato, essas duas figuras, junto com as outras que são mencionadas no Politico (267e), representam de maneira sintética o saber técnico contraposto à ignorância comum 
da maior parte das pessoas. Tal saber possui uma superioridade natural, documentada por seu sucesso, e reconhecida por aqueles que dele desfrutam. Mas o mito demonstra justamente que o saber do político no fundo não se assemelha ao saber técnico.

Essa conclusão poderia contrastar com o que sabemos do pensamento político platônico por outros meios. De fato, é sabido que nos diálogos da juventude o modelo técnico e médico é invocado justamente para mostrar qual deve ser a natureza ideal da ciência política, diametralmente oposta ao senso comum (e à tese de Protágoras) que admite qualquer um em cargos públicos. Mas não há uma verdadeira contradição. Para Platão, o modelo técnico sempre desempenhou mais o papel de uma ideia limite, com valor regulador, do que de um programa concretamente viável. Sem dúvida, seria certamente desejável que o saber político tivesse a mesma precisão do saber técnico. Mas dado que isso não se verifica (ninguém pode possuir um conhecimento do bem e do mal comparável ao conhecimento científico de um médico), ocorre, sem renunciar à imitação do modelo na medida do possível, colocar em ação toda uma série de mediações, a fim de que a boa vida ética e política possa ser realizada pelo menos parcialmente.

A necessidade dessas regulaçóes torna-se cada vez mais forte nos últimos diálogos (Político, Timeu, Crítias, Leis). Em primeiro lugar, vemos que Platão agora distingue com maior nitidez (por exemplo, em relação à República) o político do filósofo. Também é indica- 
tivo, nos quatro diálogos mencionados, o constante regresso ao mito de uma idade primitiva na qual vigorava uma perfeição e uma excelência agora perdida para sempre. Esta insistência em regressar ao mito parece ter o efeito de afastar irremediavelmente a cópia do seu modelo. Mas é justamente evidenciando essa distância que Platão pode abrir o caminho em direção a uma relativa realização do bem (cósmico e político); enquanto se acreditasse ser bom somente aquilo que realiza de fato o modelo, a política estaria condenada à falência. Pretender que o político seja de verdade um técnico, seria pretender que o político fosse um deus, ou que o rei, como na mítica e pré-histórica idade do ouro, fosse de verdade mais sábio que seus subordinados na mesma medida em que o pastor o é para seu rebanho.

A obra de mediação de que falamos encontra no Político diversas modalidades de expressão. Em primeiro lugar, é significativa a segunda divisão, que serve como modelo de método correto para definir o político, mais ou menos como no Sofista a divisão do pescador com o anzol. Tal divisão, que tem por objeto a tecelagem, fornece à investigação um elemento determinante para se compreender plenamente a natureza do político (279a-283a). Assim como no modelo da tecelagem a divisão tem o efeito de identificar, juntamente com a arte de tecer, também todas as artes que à tecelagem estão ligadas como auxiliares, do mesmo modo, uma correta definição da arte política não pode prescindir da determinação das disciplinas 
que são subordinadas à política e das quais ela se serve (Platão escreve que são suas causas por concomitância, 287b-289a).

Dessa análise, emerge a complexidade da atividade política e a dificuldade de lhe aplicar o modelo definitivo mais pretensioso, virado para a identificação de uma ideia para cada coisa: de um lado, a ciência política não pode passar sem muitas outras artes técnicas e, por outro, o político, se realmente faz jus a sua função, deve demonstrar possuir dentro de si mesmo certas funções que nas sociedades da época eram erroneamente reservadas a outras classes de indivíduos (sobretudo, aos sacerdotes: 290d-e).

\section{AS DIFERENTES CONSTITUIÇÕES E A IMPORTÂNCIA DAS LEIS}

Mas a necessidade de encontrar um ponto de equilíbrio eficaz entre a perfeição do modelo e a inevitável superficialidade das suas imitações é visível sobretudo na importância que o Político atribui às leis e à maneira diferente, relativamente à República, em que se organizam as diversas constituições.

Tais formas de governo são, antes de tudo, classificáveis segundo o número, como o governo de um, governo de poucos e governo de muitos (291d). Mas junto à variável do número o Estrangeiro introduz também outras, como pobreza e riqueza, violência e liberdade, com leis e sem leis. Rigorosamente falando, 
nenhuma dessas variáveis é determinante para estabelecer a natureza da verdadeira arte política. O elemento que distingue a constituição política ideal é ascensão ao governo de um ou mais homens possuidores da técnica política, ou seja, da ciência capaz de identificar caso por caso o que é bom, com base na justa medida. Para Platão, é óbvio que, se esses homens existem, podem governar, quer sejam muitos ou apenas um, quer o façam pela persuasão ou pela força, quer com ou sem leis: efetivamente serão capazes de produzir de maneira infalível aquele bem e aquela felicidade que todos os homens naturalmente desejam (293d-294c).

Platão confirma, portanto, mais uma vez, um princípio ao qual se manteve fiel ao longo de todo o seu pensamento. $\mathrm{O}$ bem é o único valor verdadeiramente suficiente, e nada mais o pode subordinar: nem a lei e nem mesmo a liberdade. Todavia, retorna aqui de maneira amplificada a mesma duplicidade de planos representada no mito, isto é, aquela chamada de atenção para a desigualdade entre modelo e realidade, que é a característica peculiar da última fase do pensamento de Platão. Porque o modelo de uma ciência política entendida como técnica perfeita e infalível não pode ser realizado (a ciência política poderia em todo caso ser possuída por pouquíssimos: 293a), torna-se essencial identificar as formas políticas concretas que mais se aproximam do modelo perfeito, em outras palavras, que o imitem com maior fidelidade. Se é verdade que se equivocam aqueles que apoiam incondicionalmente a democracia, porque acreditam ser possível um agir 
ético-político, mesmo na ausência de uma norma e de um bom modelo que sirva de inspiração, quem, ao invés, acredita ser possível a instauração de um governo tirânico bom, confiado a um técnico da política que conheça perfeitamente o bem e o mal, parece ser demasiadamente otimista. Talvez também por causa das más experiências vividas na corte dos tiranos de Siracusa, agora Platão parece mais preocupado com os perigos de um governo que não respeite as leis (ver. 300a) do que com a necessidade de definir a política como uma ciência pura de um bem superior a qualquer lei (como, pelo contrário, acontecia n'A República).

Esse modo diferente de sopesar as coisas vê-se, sobretudo, na característica ambiguidade da lei, à qual o Político está condicionado e que, mais adiante, dará corpo à última grande obra de Platão. O Estrangeiro e seu interlocutor não estão convencidos a admitir que o modo justo de governar seja aquele que se desenvolve sem as leis. Se o uso das leis não conta no estado perfeito, pelo contrário, ele é essencial para qualificar as imitações, ou seja, os estados que o assumem como modelo (297b-c). Com base nesse critério, os três regimes imitativos se desdobram, um em relativamente bom e outro em um relativamente ruim. O governo de um e o governo de poucos, de acordo com o respeito ou a falta de respeito às leis, dividem-se assim, de um lado, em monarquia e aristocracia, do outro, em tirania e oligarquia. A mesma distinção, mesmo sem nomes específicos, pode ser feita naturalmente também para a democracia. Agora que as constituiçóes se 
transformaram em seis, é possível estabelecer também sua bondade e maldade recíproca.

Esta classificação é estranhamente assimétrica, porque nas extremidades temos a tirania (a pior) e a monarquia (a melhor); em seguida, de cada lado, a oligarquia (a pior depois da tirania) e a aristocracia (que é a melhor depois da monarquia). Com ou sem o conforto das leis, as duas formas de democracia ocupam, respectivamente, o terceiro e o quarto lugar de acordo com a medida do melhor e do pior (302b-303a). O critério que guia essa qualificação é dado pela potência dos regimes examinados. O mais potente de todos é o regime de um só homem, por isso, se o governante é bom, dele derivará o bem máximo; mas, se é ruim, teremos o máximo mal. Pelo mesmo motivo, a democracia é incapaz tanto de grandes bens quanto de grandes males, razão pela qual, se dela não se pode esperar resultados excelentes, pelo menos estamos seguros de que não produzirá danos irreparáveis.

Também nessa avaliação deve ter sido importante a grande experiência que Platão possuía no âmbito da democracia ateniense, que the pareceu de toda forma um regime melhor do que os dos Trinta Tiranos, não obstante o infeliz acontecimento do processo de Sócrates. Na medida em que Platão chama a atenção sobre a impossibilidade de realização do regime perfeito e sobre a relativa dificuldade de se concretizarem também os estados que dele mais se aproximam, na mesma medida, também ganham terreno na sua mente regimes mistos, e a própria democracia. 
A necessidade de acomodação a um regime que imite aquele perfeito constitui-se na tradução em termos políticos daquela que, no Fédon, no Filebo e também no Político, é chamada "segunda navegação". No Político, a segunda navegação consiste justamente em organizar o governo mediante as leis, e em não permitir a ninguém ou a nenhum grupo que o critique (300c). As leis, de fato, possuem de sua parte o prestígio da antiguidade e da tradição, baseando-se sobre uma vasta experiência e sobre conselho de homens que meditaram sobre elas em particular e que persuadiram a população a votar nelas (300b). Este tema da persuasão é particularmente interessante. No fundo, aquilo que distingue, entre os governos imitativos, os legais dos ilegais, é o uso da persuasão no lugar da violência. Se o governante é o especialista soberano do bem, aos homens será conveniente aceitar também sua violência. Mas se é ruim, o único antídoto será a liberdade. E dado que Platão sabia que nunca há a certeza de encontrar um homem verdadeiramente possuidor da ciência, a persuasão e a liberdade constituem o destino inevitável do homem.

Não é de se espantar que quando o Estrangeiro volta a falar, no Político, sobre as ciências auxiliares da política, reapareça improvisadamente também a retórica, que no Górgias foi julgada negativamente, e no Fedro parecia ser parte integrante da filosofia. No Político, diz-se, em vez disso, que a retórica é uma ciência distinta da política (Platão usa o forte vocábulo episteme, isto é, ciência), e a esta está subordinada, no 
sentido que a política comanda a arte do discurso e da persuasão (304c-d). Confirma-se, assim, que nenhum homem pode dispor concretamente de uma ciência política tão forte e segura de si a ponto de sentir-se autorizado a promover seus resultados com a violência.

\section{AS LEIS: ALGUMAS QUESTÕES INTRODUTÓRIAS}

As Leis, a última e mais longa obra de Platão (doze livros), suscitou nos estudiosos várias incertezas, tanto que lhe dedicaram uma atenção relativamente modesta, e alguns chegaram até mesmo a pensar resolver o problema declarando-a espúria. Mas as Leis eram consideradas obra de Platão também pelas testemunhas antigas e, em primeiro lugar, pelo próprio Aristóteles. O que há de tão estranho nesse diálogo? O maior problema é dado pelo fato que a tensão teorética é de certa forma modesta, e ali quase nunca aparecem os temas mais característicos da epistemologia e da metafísica de Platão. Outra questão difícil concerne à relação das Leis com A República: visto que nas Leis Platão delineia os contornos de um estado ideal, assim como o fez n’A República, quais são as razões que o motivaram a escrever essa espécie de duplicata? E quais são precisamente as relações entre as duas obras?

O primeiro problema pode ser resolvido de maneira bastante simples. Por um lado, os diálogos de Platão habituaram os leitores a não esperar encontrar, em 
todos os seus escritos, referências precisas aos mesmos princípios e às mesmas doutrinas (sobretudo porque às vezes possuem intenções divergentes); por outro, encontramos uma estrutura metafísica de base presente (como veremos) também nas Leis: basta que não se sustente que tal estrutura deva necessariamente assumir, em Platão, a forma da doutrina das ideias.

Mais complexo é o problema da relação $\operatorname{com} A$ República. A hipótese mais simples consiste em considerar que as Leis são uma espécie de transcrição realista da teoria platônica do estado ideal. Considerando, além disso, que a Academia platônica teve a incumbência prática de formar legisladores, chegou-se mesmo a pensar que esse diálogo fosse uma espécie de manual escolar, elaborado para o uso dos acadêmicos que assumiam responsabilidades legislativas. Mas não é o caso de insistirmos muito nesse ponto. Se for verdade que nas Leis as propostas políticas de Platão parecem menos drásticas, não se deve esquecer que também nesse caso estamos diante de um modelo, (ver Leis 746a-d): um modelo, como veremos, que é construído a partir de princípios substancialmente análogos àqueles que governam $A$ República. Poderíamos, portanto, supor que Platão, escrevendo as Leis, tinha a intenção de propor a seus contemporâneos um estado ideal menos difícil de ser imitado do que aquele preconizado n'A República. 


\section{AS CARACTERÍSTICAS GERAIS \\ DA EDUCAÇÃO}

Três amigos: um anônimo Ateniense, o espartano Megilo e o cretense Clínias, decidem fazer uma viagem juntos e, para passar o tempo, começam a discutir sobre suas respectivas constituições. No primeiro livro, o Ateniense observa que as constituições de Creta e de Esparta foram criadas sobretudo em função da guerra e que, por consequência, visam a promoção exclusivamente da virtude da coragem. Mas tal abordagem é reducionista, porque a coragem é somente uma das quatro virtudes, e é claro que a justiça, a temperança e a inteligência, unidas à coragem, serão superiores à coragem considerada isoladamente (630b). É preciso, assim, pensar que os legisladores de Creta e Esparta, que possuíam a sabedoria dos deuses, criaram suas constituiçôes colocando em primeiro lugar a condução da inteligência: se houve um erro, foi causado por quem interpretou de forma redutora suas prescrições. De fato, as leis têm como finalidade a atuação integral da virtude (632e-633a) e ninguém deve pensar, considerando a divindade de seus artífices, que foram produzidas para outro fim que não seja o bem (633e-634a).

Cretenses e Espartanos entenderam muito bem que a educação geralmente tem o objetivo de transformar os homens capazes de resistir à fadiga, à fome e aos mais diversos perigos. Mas não consideraram que a mesma educação exige também uma capacidade de 
resistir aos prazeres. Sob esse aspecto, a constituição de Atenas é a melhor, visto que difundiu o uso dos simpósios e das refeiçôes em comum. Efetivamente, seria necessário que os homens aprendessem também a temperança, e que provassem aquela quantidade mínima de prazer suficiente para lhes permitir que resistam aos prazeres.

A prática dos simpósios tornou-se, assim, o símbolo de uma educação voltada para a formação do caráter do homem por completo, incluindo também a urbanidade e o senso cívico que pode eventualmente faltar quando se instrui os homens somente para saírem vitoriosos em guerras (641c). A educação para a virtude consiste efetivamente, prossegue o Ateniense, em suscitar nos mais jovens o desejo e o amor por se transformarem em ótimos cidadãos, capazes de comandar e serem comandados com justiça (643e). Implícito nessa importante definição está o fato que o homem virtuoso deve ser capaz, em primeiro lugar, de comandar a si mesmo, de outra forma, não será de verdade bom (644b).

Assim, o discurso se desloca para um âmbito psicológico. Referindo-se a temas já expostos em outros diálogos, o Ateniense menciona a complexidade da vida psíquica, onde constantemente ocorrem conflitos entre impulsos antagônicos (644e-645c). A educação que podemos chamar "humanística", fundada na temperança, na moderação e no correto uso do intelecto, é certamente superior à severa e belicosa pedagogia dos cretenses e dos espartanos. Mas a razão não é violenta 
e não possui por si a força de se impor na alma dos jovens. Por esse fato, é necessário que ela seja acompanhada de estímulos de caráter sensível e irracional que, guiados pela lei em direção ao justo fim, poderão conduzir a alma ao hábito da virtude.

No segundo livro, a análise da educação dos jovens para a virtude, entendida como reta orientação em relação aos prazeres e às dores $(653 \mathrm{c})$, avança fazendo-se referência à poesia e à música. Nessa seção é retomada a mesma perspectiva presente n'A República, segundo a qual, em um estado corretamente governado devem ser permitidas somente as manifestações artísticas que contribuam para o bem e para a formação dos bons costumes, e que não se deve considerar, na avaliação, a opiniāo da maioria ou a finalidade do prazer. Mas o discurso parece também, de certa forma, menos rígido. Platão parece reavaliar aqui a função da poesia, entendida como exemplo válido dos meios irracionais dos quais a educação ética e filosófica é obrigada a se servir: ela tem o efeito de produzir nos homens uma espécie de encanto, e condu-los com grande sutileza em direção à obtenção da virtude. A razão do encanto constitui o tema que atravessa todo o segundo livro, e o Ateniense tem o cuidado de explicitar que isso diz respeito não somente aos jovens, mas a todos os homens, incluindo os anciãos. O encanto serve para persuadir os homens de que a vida virtuosa é também a vida mais feliz e prazerosa. 


\section{OS FUNDAMENTOS ÉTICOS DA POLÍTICA E O PROJETO DE UMA LEGISLAÇĀO IDEAL}

O terceiro livro se abre com o problema da origem do estado. Sobre esse tema, o Ateniense introduz um mito, no qual imagina que a civilização dos homens teria se formado depois de uma sequência de periódicas catástrofes e inundaçóes. $\mathrm{O}$ início proporcionador da civilização é o momento em que, depois de uma inundação, os homens se encontraram reduzidos a um pequeno grupo de habitantes das montanhas, dispersos e isolados entre si. Seus costumes se conservaram simples e puros. São homens que chamam as coisas pelos seus nomes, não conhecem o engano nem a mentira, e das poucas vezes que se encontram fazem-no com alegria, sem querer se sobrepor uns aos outros. Nessas condições, não necessitam nem de sociedade nem de leis, mas se governam de acordo com os hábitos de seus antepassados. A política nasce somente quando, crescendo o número de habitantes, começam a descer das montanhas e se misturarem com outros grupos, e assim se veem obrigados a confrontar seus próprios hábitos com os dos outros. Daí, surgem os primeiros estados, as primeiras leis e os primeiros legisladores (677a-681c).

O início desse novo estilo de vida não é complicado, graças à bondade natural de seus costumes. $\mathrm{O}$ Ateniense descreve as diversas fases desse processo, que conduzem à constituição dos primeiros estados dóri- 
cos, Esparta, Argos e Messena, providos de ótimos governos e ótimas leis. Todavia, com o passar do tempo, essas felizes realidades se corrompem, como demonstram as lutas intestinas ocorridas no tempo das guerras persas. Segundo as temáticas que bem conhecemos, Platão justifica esse resultado negativo pelo fato que os políticos daquela época careciam de conhecimento, particularmente do conhecimento do que é o bem e o mal para o homem; e trata-se de um grave defeito, porque quem se encontra nessa condição pode amar e desejar coisas más, ou vice-versa, odiar e recusar as coisas boas (689a).

Portanto, o verdadeiro político é só quem conhece o bem. Mas, em coerência com o desenvolvimento que esse tema tem nos últimos diálogos, o bem é agora identificado com a justa medida, no sentido daquela harmoniosa moderação já visível no Filebo e no Político. A primeira aplicação deste princípio tem-se na determinação do melhor regime político em geral. Visto que as principais formas políticas são a monarquia e a democracia, a melhor constituição será aquela que acolher uma mistura equilibrada dessas duas (693d). Tal juízo é sustentado por dois exemplos históricos iguais e contrários: de um lado o estado persa, que prosperava quando a natureza monárquica do poder era moderada pela liberdade de expressão e pela tolerância, e que decaiu quando prevaleceu uma prática tirânica; de outro o estado ateniense, que gozou de uma vida feliz quando a estrutura democrática do poder era regida por princípios de caráter monárquico, 
e que ruiu desastrosamente quando a democracia se estendeu sem freios.

No final desse livro, o cretense Clínias revela ter sido encarregado, com outros nove, de redigir as leis para uma colônia que seus compatriotas pretendiam fundar na ilha. Assim, os três amigos decidiram continuar o discurso como se estivessem estabelecendo as bases para a criação de um novo estado, de modo que Clínias pudesse extrair da discussão alguma utilidade concreta $(702 \mathrm{~d})$.

O Ateniense se ocupa, antes de tudo, de elencar as condições de realização do modelo que se prepara para descrever. Postas algumas condições de caráter material, ele admite em primeiro lugar a incidência do caso (709a-c). De modo análogo ao que Platão já havia dito n'A República (mas com uma pitada a mais de realismo), a possibilidade de uma constituição vir a ser excelente depende da verificação de determinadas contingências, como o surgimento sortudo de um príncipe que possua por natureza as qualidades necessárias para ser um bom político, ou seja, inteligência e moderação. Ocorre, em outras palavras, que o máximo de temperança e de inteligência se unam com o máximo de poder (712a).

Estabelecido isso, é necessário edificar as leis deste estado. A perfeição ideal seria a de um regime governado por um deus. Com essa finalidade, é introduzido o mito de Crono, que já mencionamos quando falamos do Político (ver p. 180), onde se contava de um tempo em que os deuses guiavam a vida dos homens para o 
bem e para a felicidade. Ao invés disso, nos estados governados por mortais e não por deuses, não se pode escapar dos males e das dores; por isso, os governantes devem desenvolver ao máximo aquilo que possuem de divino, imitando a vida feliz do tempo de Crono. O resultado dessa imitação é justamente a lei, que é a tradução normativa de tudo que a inteligência estabelece (714e); de modo que o respeito às leis, nos estados concretos, terá a função da obediência aos deuses no reino de Crono, e permitirá aos homens realizar uma imitação eficaz do perfeito estado ideal.

O princípio segundo o qual a verdadeira medida das coisas não é o homem, mas deus, que contém uma polêmica e explícita alusão ao célebre lema de Protágoras (716c), é aqui inserido na sensibilidade realista típica dos últimos diálogos: o bem e a medida são divinos e por isso superiores ao nomos (que significa ao mesmo tempo "lei" e "convenção"); mas é somente mediante o nomos que esse bem divino se revela ao homem. Para explicar no que consiste esse bem, o Ateniense expõe de maneira sintética os princípios éticos que devem guiar sua formulação. Em primeiro lugar, ocorre venerar os deuses e respeitar os anciãos, e, em segundo, ter uma relação saudável com os filhos, parentes e hóspedes: o papel dos poetas será representar em suas obras somente os bons comportamentos. 


\section{A NECESSIDADE DE QUE AS LEIS SEJAM PRECEDIDAS POR UM PROÊMIO}

Trataremos agora do argumento, sem dúvida, mais importante do livro. Os princípios enunciados anteriormente constituem uma espécie de proêmio às leis, que deve ser exposto antes da elaboração das leis propriamente ditas. Enquanto as leis sancionam e punem sem a necessidade de justificação, o proêmio serve para convencer os cidadãos da bondade da lei, e será lícito ao governante utilizar meios coercitivos apenas depois de ter usado toda a força de persuasão que possui (722c-723b).

Para explicar esse ponto, Platão faz uso novamente do exemplo do médico, mas desta vez com outra intensidade. No Górgias e no Político a arte médica representa um saber técnico perfeito que dispensa a persuasão. Mas nas Leis Platão distingue dois tipos de médicos, uns que não diagnosticam nada sem primeiro ter persuadido seus pacientes (são esses os médicos dos homens), e outros, que se limitam somente a comandar (são os médicos dos escravos). Assim como dentre os dois médicos é preferível o primeiro, por usar ambos os métodos, do mesmo modo uma política fundada sobre a persuasão em vez de sobre a coerção é preferível àquela que se limita a comandar (720be). O proêmio está para as leis como a persuasão está para o comando. Dessa forma, a comparação com o médico amarra o discurso que Platão está fazendo aqui à característica específica, de que ele faz uso nos últi- 
mos diálogos, do modelo teórico. O saber filosófico e político é e só sempre imitação do saber divino, não possui o poder coercitivo dado pela evidência e, por isso, deve confiar pelo menos uma parte da sua eficácia ao meio retórico da persuasão e da educação da alma.

O proêmio para as leis conclui-se, na primeira parte do livro quinto (726a-734e), com uma espécie de resumo da ética platônica, recheada de temas socráticos e rico de alusōes aos diálogos da juventude. Entre outras coisas, encontramos também o tema da superioridade da alma em relação ao corpo, do qual os homens precisam cuidar, honrando-a logo depois de honrarem os deuses; o clássico ensinamento socrático segundo o qual o mal é cometido sempre por ignorância, e nunca volutariamente (731c); e a confirmação da natureza puramente eudemonista (ou talvez até mesmo hedonista) da moral (731e-734c).

\section{A “UTOPIA” NAS LEIS}

Um sistema político se constitui, antes de tudo, pela distribuição da magistratura entre os diversos grupos de homens. Mas, antes disso, é preciso que a população seja purificada da melhor maneira possível, se necessário, também por meio de métodos dolorosos. O Ateniense não esconde a dificuldade de realizar uma operação semelhante; mas, como sempre, a natureza ideal do modelo permite ao discurso esquivar-se de imediatos vínculos práticos (736c). N’A República, 
como também nas Leis, a economia é o ponto de partida para a política e para a legislação. É fundamental para o bem-estar de um estado o equilíbrio e a justa medida na administração das riquezas, porque as desigualdades e as ambiçôes econômicas são as principais causas das discórdias entre os cidadãos.

O Ateniense relembra propositalmente o argumento já invocado n'A República para estabelecer a comunidade dos bens e em seguida das mulheres, isto é, que as coisas dos amigos são comuns (739c), e define que a melhor constituição seria justamente aquela organizada desse modo. Mas, nas Leis, o modelo se articula em vários níveis, por esse motivo, é necessário não apenas estabelecer o ótimo em absoluto, mas também o que ao ótimo mais se aproxima, e, depois, eventualmente, determinar também outros níveis inferiores (739a-b). Já que o estado perfeito onde tudo é dividido é irrealizável, é necessário pensar em um estado restrito a um número fixo de famílias (5040, número escolhido pela abundância dos seus divisores), em um território limitado e distribuído em partes iguais, uma parte de cidade e uma de campo, balanceando proporcionalmente o tamanho do terreno de acordo com a fertilidade do solo.

As normas que regularão a vida desse estado têm por finalidade mantê-lo o máximo possível no feliz estado de igualdade em que se encontra. Assim, serão multados os cidadãos que não se casarem (721a-b); para não dispersar o patrimônio ou modificar o número de famílias, vigorará a norma da primogenitura 
junto com a da adoção (quem não tem filhos adotará os segundos filhos e os terceiros de outras famílias; as filhas, não é preciso dizer, serão destinadas ao matrimônio); os bens imóveis serão declarados inalienáveis; o comércio reduzido ao mínimo; a desigualdade entre patrimônios poderá oscilar apenas de forma limitada, em proporção de uma unidade a quatro: nenhum cidadão poderá possuir menos que a unidade e nem mais do que o quádruplo da mesma (nesse caso, os bens excedentes serão confiscados pelo estado); existirá uma moeda corrente, somente para o uso interno: e quem chegar do exterior com uma moeda estrangeira, deverá trocá-la pela moeda do país (739e-745a).

Esses princípios, como dissemos, são os mesmos d'A República. O propósito da vida em grupo é que os cidadãos alcancem o máximo grau de felicidade (743c). Tal felicidade é obtida somente com a concórdia, que, por sua vez, depende essencialmente da igualdade. Mas, enquanto n'A República havia um desequilíbrio entre igualdade absoluta, reservada aos guardiōes e governantes, e liberdade econômica, concedida à maioria da população, nas Leis, o ideal de igualdade, mesmo que debilitado, é estendido a todos os cidadãos: de modo que alguém observou que o programa das Leis é ainda mais utópico e irrealizável do que o d'A República.

Mas este não é o verdadeiro problema, porque, em ambos os casos, trata-se somente de um modelo ideal, em si e por si irrealizável. Quando muito, a diferença consiste no fato que, n’A República, Platão 
dava grande importância à excelência dos governantes e, nas Leis, ele tem em mira sobretudo uma bondade relativa, da qual todos os cidadãos são igualmente cientes e responsáveis. Nesse sentido, o estado descrito nas Leis certamente não é mais utópico do que o d'A República. Mas é útil acrescentar que esta característica não pode ser automaticamente considerada um mérito. De fato, n'A República entra em ação um plano audacioso capaz de opor-se à tradição, enquanto o chamado realismo das Leis, no fundo nada mais é que uma tentativa de corrigir uma utopia muito forte em relação aos costumes tradicionais. Nas Leis, em suma, é possível perceber a voz do velho conservador ateniense, ligado aos costumes do campo, desconfiado de toda e qualquer forma de excesso, apreciador da justa medida, mais próxima às orientações do senso comum do que dos princípios da filosofia.

\section{LEIS E SOCIEDADE CIVIL}

A maior parte do livro sexto é dedicada à descrição das magistraturas. A palavra de ordem é que, na medida do possível, tudo deve ser regulado e nada deve escapar da vigilância. Contudo, não há neste modelo político nenhuma idolatria às leis, porque muito mais importante é a virtude de quem desempenha os cargos; por outro lado, as leis devem ser continuamente colocadas em prova e modificadas conforme requerido pelo confronto com os fatos. 
Ao determinar os acessos às magistraturas, Platão aplica o princípio realístico da mediação de que tantas vezes já tratamos. Os cargos são decididos através de eleiçôes, e todos os cidadãos podem contribuir com seu voto. Mas existem mecanismos que modificam esse princípio em um sentido aristocrático. Primeiramente, as votaçóes se realizam em diversos turnos, de modo que as repetidas seleções façam emergir realmente os mais dignos. Em segundo lugar, somente os cidadãos das duas primeiras classes sociais são obrigados a participar da vida política, sob pena de multa; enquanto para os cidadãos de quarta classe (em certos casos também os da terceira), tal participação é facultativa $(756 \mathrm{c}-\mathrm{d})$.

Com essa norma, Platão quer, mas sem tolher o direito de ninguém, filtrar o acesso aos cargos governamentais e manter, assim, a constituição na justa medida entre a monarquia e a democracia (756e). A mesma orientação é visível também na determinação da verdadeira igualdade. Posto o princípio, já anunciado n'A República, que somente a igualdade é causa da concórdia (,-d), existem dois tipos diferentes de igualdade: uma consiste na igual distribuição de todas as coisas, que podem ser regulamentadas com sorteios; e outra, mais verdadeira, consiste em dar mais a quem vale mais, ou seja, a quem é mais virtuoso. Um estado bem ordenado deverá misturar com equilíbrio esses dois gêneros e, particularmente, deverá também prever a distribuição dos cargos por sorteio. $\mathrm{O}$ uso desse método deverá ser limitado ao máximo, mas é inevitável para prevenir as sediçôes (757d-e). 
Interessantes, portanto, são as prescrições relativas aos escravos e às mulheres. Enquanto, no que diz respeito às mulheres, o Ateniense sustenta, com um pouco mais de precisão, as mesmas condições de igualdade já teorizadas n'A República (ver 783d-785b), aqui encontramos uma exposição do papel e da natureza do escravo, do qual, n'A República, não se fazia qualquer comentário (porém, no Político 289a-e, existia alguma menção a respeito). A distinção entre livres e escravos é tida por Platão, de acordo com a mentalidade do seu tempo, como necessária. Mas é muito complicada de estabelecer, porque não é fácil fazer com que os escravos aceitem seu papel de subordinação. Por isso, é necessário que os patrōes ajam com justiça em relação aos escravos, mais ainda que em relação aos homens livres (porque a virtude se manifesta sobretudo, nos comportamentos que os homens têm com quem está à sua mercê), porém, o patrão deverá evitar qualquer familiaridade, e usará o comando em vez da persuasão, porque, caso contrário, danificará o caráter do escravo tornando-o estranho à obediência $(777 \mathrm{~d}-778 \mathrm{a})$.

\section{A EDUCAÇÃO}

$\mathrm{O}$ argumento do livro sétimo é a educação. Também aqui Platão reutiliza o desenho d'A República. A educação deve abranger totalmente a vida do homem, do início ao fim (sugere-se até mesmo uma espécie de ginástica pré-natal), porque as crianças pertencem 
primeiramente ao estado, só depois aos seus genitores (804d), e as normas que regulam a sociedade constituem a medida do bem para todos. Como sabemos, essa educação diz respeito ao corpo e à alma: o corpo é exercitado por meio da ginástica, da luta, da prática da guerra, da dança, etc.; e a alma mediante a instrução musical e literária, depois também pela aprendizagem da matemática e da astronomia.

No que diz respeito à poesia, são aplicadas as habituais ressalvas, particularmente em relação à tragédia. Explica o Ateniense que, se se deseja encontrar um modelo correto para a produção literária, este é dado em primeiro lugar justamente nos discursos que estão sendo feitos em torno das leis: não existe no estado a necessidade real de poetas, e os poetas que pretendem ser aceitos devem se conformar a tal modelo (817a sqq.). Assim se confirma a hipótese de que Platão pensava suas próprias obras como uma espécie de epos e de tragédia filosófica, que teria a função de substituir a poesia tradicional na educação.

O objetivo geral da pedagogia das Leis, mais uma vez em harmonia com $A$ República, é tornar a vida do homem idêntica e imóvel e sempre igual a si mesma o máximo possível. Para afirmar que o idêntico seja o bem, ocorre encontrar a medida que mais se aproxime a ele e, sobre essa base, organizar a vida de maneira repetitiva. Mas Platão se embaraça quando tenta legislar acerca de aspectos mais particulares e mínimos da educação: existe o risco de tornar-se ridículo. E, todavia, mais grave é o risco de que aquelas inúmeras 
pequenas coisas desconhecidas do público, que acontecem no segredo do lar (788b), corrompam e tornem vã a educação imposta pelas leis.

A solução para este problema consiste em encontrar um equilíbrio entre a lei escrita e o arbítrio, através da formação do costume e da prática (808a). Independente de qualquer julgamento de mérito é necessário reconhecer que Platão aponta aqui um problema de grande relevo. Nada poderão fazer as leis se os costumes de um povo não forem já orientados de uma certa maneira; nem é possível pensar em modificar os costumes apenas introduzindo prescrições: é preciso uma longa prática educacional e um grande respeito por algumas tradiçóes, para que os comportamentos corretos se produzam regularmente, por hábito.

\section{JUSTIÇA, MALDADE, VOLUNTARIEDADE E INVOLUNTARIEDADE}

O oitavo e o nono livro contêm casos legislativos bastante minuciosos, que dizem respeito à vida social e civil (organização das festas e das competições, regulamentação de relações sociais, questôes de direito privado, etc.), e à administração da justiça, que aqui deixaremos de fora. Porém, no nono livro existe uma discussão sobre o conceito de justiça que vale a pena citarmos (857c-864a). O princípio fundamental é que a repressão do crime deve ter caráter educativo e não punitivo, isto é, a lei deve ter a tarefa de instruir e per- 
suadir o culpado a mudar o próprio comportamento (862d). Tal princípio se sustenta na célebre máxima socrática, a qual já repetimos tantas vezes, segundo a qual ninguém faz o mal voluntariamente. Mas esse estado de coisas não exclui a pena capital, quando a corrupção do réu for incurável (862e).

$\mathrm{O}$ esquema delineado agora deixa em aberto pelo menos dois grandes problemas: 1) se o mal é involuntário, a lei não fará distinção entre as várias ações e não considerará a intenção do agente? 2) se o mal é ignorância, o único remédio sensato é a divulgação do conhecimento; então por que a necessidade da pena de morte? Em relação ao primeiro ponto, o Ateniense explica que o mal, normalmente chamado involuntário (como, por exemplo, um dano inadvertido de um bem), não representa de todo um caso de injustiça, e será mal somente na medida em que causar um dano; por isso, pode ser simplesmente reparado com um ressarcimento. Ao contrário, a injustiça diz respeito ao bem (862a-b), no sentido que se diz injusto aquele que busca, para si mesmo ou para outros, um bem que não é tal. Por isso, a ação educativa das leis tem a tarefa de explicar a quem não entendeu bem em que consiste o verdadeiro bem e a verdadeira felicidade.

Mas a injustiça não deriva somente de um erro do intelecto. Suas causas são também as paixões (em primeiro lugar, a ira) e os desejos (sobretudo de prazer); por isso, a injustiça pode ser definida como "a tirania exercida na alma pela ira, pelo medo, pelo prazer, pela dor, pela inveja, pelos desejos, quer produzam danos 
quer não" (863e-864a). Dessa forma, é possível que tais fatores tenham agido em uma alma tão profundamente ao ponto torná-la incurável. Para essas almas assim degeneradas, a reeducação não seria de nenhuma utilidade e, portanto, não restará nada mais que a pena de morte: a qual, nesse caso, será duplamente útil, porque purifica a cidade dos malvados e serve de exemplo para os outros (862e). Platão permaneceu por toda a vida fiel ao princípio socrático segundo o qual a vida só tem valor se for boa.

\section{O DÉCIMO LIVRO: A RELIGIÃO E OS DEUSES}

O décimo livro das Leis é o mais filosófico de toda obra. Partindo da necessidade ética e política de convencer os cidadãos da existência dos deuses, Platão dedica esse livro à demonstração que os deuses existem e realizam uma ação providencial em relação ao mundo e aos homens. Quem de fato comete uma ação ímpia ou fala mal das leis age assim ou porque não crê nos deuses (885b), ou porque não acredita que eles tenham influência sobre a vida dos homens, ou até mesmo porque acreditam que os decretos dos deuses possam ser modificados mediante sacrifícios e oraçóes. Por isso, o Ateniense se dispóe a refutar por ordem essas três posições.

Mas antes se deve aprofundar uma questão do ponto de vista metodológico. É lícito impor por lei a convenção de que os deuses existam, ou é necessário 
usar a persuasão? Naturalmente o segundo método é o mais justo. Precisamente neste caso, a lei precisa de um proêmio: um proêmio do qual a amplitude não suscite preocupação, porque, de certa forma, ele constitui também o proêmio de toda a construção legislativa $(887 \mathrm{a}-\mathrm{c})$. Se, com efeito, no campo ordinário em que se põe em prática a legislação pode ser também suficiente para o cumprimento de um comportamento externo, mesmo apoiado sobre uma persuasão incompleta, a fé nos deuses é aqui o emblema daquela persuasão interior acerca do ordenamento bom e justo do mundo que age diretamente sobre a alma e a faz mover-se, e sem a qual nenhuma norma particular poderia ser eficaz.

Platão sabe bem que na sua sociedade, a fé ingênua nos deuses, que antigamente era absorvida através de mitos, por boca das amas $(887 \mathrm{~d})$, praticamente não existe mais, sobretudo em função do materialismo naturalista e da sofística. Isso não quer dizer que ele aspirasse a um puro e simples retorno aos costumes antigos. Mas a culpa dos inovadores permanece e é grave, porque eles conseguiram destruir a toda fé no divino e semearam os germes do ateísmo, sem ter argumentos comprobatórios a seu favor (887e).

Platão reúne em sua crítica, em um único grupo de perversos corruptores, os filósofos naturalistas, os sofistas e os imoralistas em geral. Os primeiros são responsáveis por terem encontrado na matéria e nos agentes mecânicos as causas de tudo o que existe; de terem dito que as coisas derivam em grande parte da natureza e do acaso, e de terem limitado as causas téc- 
nicas (isto é, providenciais e inteligentes, como o demiurgo do Timeu) restringindo-as somente ao campo das atividades humanas". Nessa mesma linha se colocaram alguns sofistas, para os quais os deuses não existem por natureza, mas são frutos da convenção e invenção dos homens.

Privilegiar essa convenção produziu, por sua vez, efeitos éticos devastadores. Uma vez eliminado o divino, que representava a garantia metafísica para a estabilidade e a observância da justiça, as pessoas se habituaram a pensar que o conceito de justo poderia mudar de acordo com as circunstâncias, até o ponto de se dizer que o máximo da justiça consistia em se impor pela violência (889e-890a: aqui percebemos uma clara alusão ao imoralismo de Trasímaco e de Cálicles).

O ponto de partida da refutação platônica consiste em identificar o que propriamente pode ser dito "natureza". Para os ímpios filósofos "naturalistas", a natureza é os quatro elementos (891d). Mas o Ateniense explica que se a alma fosse anterior e mais velha que todos esses elementos, ela teria a primazia, e na realidade seria a alma a ter o maior direito de ser chamada “por natureza” (892c). Platão usa aqui as expressões "natureza" e "por natureza" para indicar, nos modos respectivamente característicos da filosofia pré-socrática e da sofistica, aquilo que funda em relação ao que é fundado (compreendendo naquilo que é fundado tanto a realidade que deriva, segundo os naturalistas, da composição dos elementos ou realidades, quanto tudo aquilo que os sofistas consideravam convencional, como, por exemplo, o nomos, porque é secundá- 
rio em relação à materialidade das necessidades e dos desejos). Se depois se demonstrar que a alma precede o corpo, será também demonstrada a anterioridade de tudo aquilo que lhe diz respeito - opinião, cuidado, intelecto, arte (techne) e lei - em relação àquilo que diz respeito ao corpo (892b).

A excelência da alma é demonstrada a partir do movimento. Entre os dez gêneros de movimento existentes o mais importante de todos é aquele capaz de mover a si mesmo e às outras coisas (894b). Se considerarmos que o movimento geral da realidade se desenvolve em uma série de movimentos que nascem uns dos outros (no sentido em que uma coisa modifica uma outra, a qual modifica uma terceira e assim sucessivamente), é necessário aceitar que o primeiro movimento é justamente aquele que consegue mover a si mesmo; porque este é o único tipo de movimento que não pressupõe uma transformação precedente, ou seja que não nasce de um movimento anterior. É possível, além disso, verificar que a capacidade de automovimento pertence às coisas que possuem vida e, portanto, alma: por isso, a alma pode, sem dúvida, ser definida, de acordo com o Fedro, como "o movimento que pode mover a si mesmo" (896a).

A passagem da alma aos deuses não apresenta dificuldades particulares. Uma vez que em cada coisa que se move de modo autônomo, devemos supor a existência de uma alma imaterial, e já que o movimento circular dos astros é entre todos o mais perfeito e ordenado, é necessário que os corpos celestes sejam divindades empossadas de almas incomparavelmente 
melhores que as humanas: pelo que se pode confirmar a célebre máxima de Tales, segundo a qual "tudo está cheio de deuses" (899b).

Uma vez demonstrada a existência dos deuses, deve-se agora provar que eles se ocupam dos acontecimentos humanos. A hipótese de que os deuses não se interessem pelas vicissitudes humanas, nasce da consideração que o mal que atua no mundo, da injustiça, graças à qual, muitas vezes, vemos prosperar os malvados, enquanto os virtuosos debatem-se entre desventuras. Se o mundo fosse governado por uma perfeita justiça divina, todo esse mal não existiria.

Supondo-se que os deuses não se interessam pelas coisas humanas (como afirmará Epicuro), esse problema não poderá ser resolvido, explica o Ateniense; porque, desse modo, estar-se-ia atribuindo aos deuses qualidades negativas, como a negligência, o ócio e a preguiça (900e). Por outro lado, não podemos acreditar que os deuses não saibam e não possam aplicar um remédio aos males que afligem o mundo; e também não é plausível que os deuses se ocupem somente das coisas maiores e ignorem os detalhes, porque dessa maneira seriam considerados inferiores aos artesãos. Mas então, como se explica o mal?

Platão, em primeiro lugar, declara que o bem do universo diz respeito ao todo antes do indivíduo e que o singular serve ao bem-estar da totalidade (903c). Ele já havia utilizado esse argumento no campo político, quando n'A República, explicara que uma qualquer possível infelicidade dos guardiōes não teria, contu- 
do, prejudicado a felicidade do estado. Mas tanto em um caso como no outro, Platão não considera esse argumento totalmente satisfatório. Assim, o Ateniense introduz outro grande tema, que foi muitas vezes utilizado para aliviar deus da responsabilidade de ser o causador do mal, ou seja, a liberdade humana. É verdade que deus governa todas as coisas da melhor forma, mas deixou aos homens a liberdade de modelar e de educar suas almas como bem entenderem, tornando-as boas ou terríveis dependendo dos casos (904c). Por isso, como no mito de Er d'A República, a responsabilidade do mal pesará em última análise sempre sobre o homem; enquanto os deuses, ao contrário, encarregaram-se de restaurar a justiça violada, distribuindo prêmios e castigos depois da morte segundo os méritos ou os deméritos.

O terceiro aspecto que se deve demonstrar, isto é, que os deuses não se deixam ludibriar pelas orações dos mal intencionados, não representa um problema, porque a natureza corrupta é incompatível com a natureza do deus. Terminado o longo proêmio, o livro se conclui com a enunciação das leis relativas à religião.

\section{OS ÚLTIMOS DOIS LIVROS: O "CONSELHO NOTURNO"}

Nos últimos dois livros o discurso torna a tratar de aspectos particulares da legislação civil (que não trataremos). A única questão filosoficamente relevante é 
enfrentada na parte final do livro doze. O Ateniense pergunta como fazer com que as leis estabelecidas durem desta forma para sempre, e que a boa constituição não sofra modificaçōes e não seja destruída. Quem deve se ocupar desse tema é o conselho supremo de custódia das leis, que se reúne de noite (961a-c).

Em vez de insistirmos em aspectos inquietantes dessa instituição (como fazem muitos estudiosos), é oportuno observar que a função do "Conselho Noturno" corresponde sinteticamente ao papel que n' $A$ República era atribuído aos governantes. Os membros do conselho, excetuando uma certa diferenciação de funçōes, representam para o estado o que o intelecto é em um organismo. Possuem a tarefa e a prerrogativa de conhecer a virtude e, particularmente, sabem em que modo a virtude, que é somente uma, se articula em quatro diferentes aspectos (que são os de sempre: sapiência, coragem, temperança e justiça). Mas esse conhecimento é somente a aplicação de um saber mais geral, que consiste em reconhecer a unidade da multiplicidade, e o universal no individual. Em suma, tratase mais uma vez daquele conhecimento que é, para Platão, o grau mais elevado da filosofia: um dar conta, fundado em procedimento de análises e sínteses, capaz de identificar o belo e o bom presente em cada coisa. 


\title{
AS DOUTRINAS ORAIS
}

\section{ONTOLOGIA E "HENOLOGIA"}

\begin{abstract}
$\mathrm{M}$
EnCiOnamos Já no CAPítulo 1 a EXISTÊNCIA de um ensinamento oral de Platão, parcialmente conservado pela tradição indireta (particularmente por Aristóteles). Além disso, dissemos que o conteúdo desse ensinamento não deve ser entendido como uma doutrina sistemática e decisiva que Platão transmitia secretamente a seus discípulos. Com efeito, a preferência que Platão manifestava a favor da comunicação oral em detrimento da escrita mostra que ele foi relutante em fixar o seu pensamento em uma doutrina bem definida e ainda mais em pensar essa teoria como determinante e conclusiva.

Dito isto, o ensinamento oral de Platão contém uma elaboração e uma articulação dos princípios metafísicos que vai exatamente na direção que já aludi-
\end{abstract}


mos várias vezes, ou seja, aquela que privilegia o aspecto pelo qual os princípios devem ser antes de tudo, causa do valor e do bem que se verifica na realidade. Com essa finalidade, com uma frequência crescente já desde os diálogos dialéticos, Platão se serve de esquemas de pensamento originários da filosofia dos Pitagóricos, nos quais as características que assinalam a presença do bem e do ótimo são traduzidas em termos matemáticos: é a ideia, já discutida anteriormente, segundo a qual o bem é traduzível em termos de unidade, ordem e proporção. Eis porque o último Platão privilegia uma metafísica na qual o princípio mais elevado (como veremos em seguida) é constituído pela noção de "uno" e de "limite", que é precisamente sinal do bem, e no qual um grande espaço é reservado a noções e a estruturas matemáticas.

Conforme foi observado, podemos, portanto, dizer que a metafísica de Platão é muito mais uma "henologia" (ou seja, uma ciência do uno) que uma ontologia (ou seja, uma ciência do ser). Essa tese só é compreensível se tivermos em conta, como dissemos algumas vezes, que o principal objetivo da filosofia de Platão não é tanto especificar, com objetivo puramente cognoscitivo, as estruturas fundamentais no ser, mas encontrar, com objetivo ético-político, os modelos do bem e do ótimo essenciais para organizar de um bom modo (de tal forma que produzam a felicidade) a vida pública e privada dos homens. Contudo, observemos agora as doutrinas orais, com base na reconstrução que nos ofereceram os intérpretes da chamada "escola de Tubingen-Milão" (escola que recentemente destacou fortemente sua importância). 


\section{O CONTEÚDO DAS DOUTRINAS NÂO ESCRITAS}

Os testemunhos sobre o Platão oral ilustram uma complexa doutrina metafísica dos princípios, com alguns aspectos similares à pesquisa sobre as causas conduzida pelos pré-socráticos. Tal tipo de pesquisa, tipicamente grego, configura-se como um processo que vai do múltiplo à unidade. Dessa forma, é claro que a necessidade de postular princípios superiores às ideias é implícita na própria teoria das ideias, na medida em que, cada ideia, mesmo sendo una em relação ao múltiplo sensível, é, contudo, parte de um conjunto. Este é um tema que também já vimos ao analisar os diálogos: particularmente n'A República, onde se fala da ideia do bem como "transcendente ao ser". Mas, enquanto n'A República e no Sofista o uno não é nomeado, nas doutrinas não escritas é dito claramente que o processo de unificação deve levar a uma unidade suprema e, além disso, também o mundo dos entes ideais é articulado de maneira muito mais específica e complexa.

Junto da unidade suprema, Platão coloca um segundo princípio, que nos testemunhos costuma ser chamado "grande e pequeno", "díade indefinida", etc. Para além da estranha terminologia (que tem toda a aparência de ser técnica, e bem familiar aos leitores e ouvintes de Aristóteles, que é nossa principal testemunha), é claro que se trata do princípio da multiplicidade (comparável, em alguns aspectos, tanto ao ilimitado do Filebo quanto à chora do Timeu). O princípio da 
unidade, também com base na identificação do bem e do uno proposta pelos famosos trechos d'A República, é superior ao ser, enquanto o princípio da multiplicidade deve obrigatoriamente ser inferior ao ser. Isso significa que toda a realidade hierarquicamente colocada em plano inferior ao uno deve participar de várias maneiras também do princípio oposto, porque o ser, de um modo geral, nada mais é que a mistura de unidade e multiplicidade.

A diferente proximidade das coisas em relação ao uno depende somente da relativa proporção com que esses dois princípios agem nos diversos níveis, partindo dos primeiros entes ideais até alcançar as coisas sensíveis. Essa diferente proporção detecta também as diferenças de valor, porque, como dissemos, a unidade para Platão é sinônimo e princípio do bem, enquanto a multiplicidade, simetricamente, só pode ser sinônimo e princípio do mal. Tal princípio é chamado por Platão "grande e pequeno" porque sua característica é poder variar de maneira indefinida e ilimitada, sem poder dar origem a nenhuma realidade determinada, a não ser que seja auxiliada pela ação da unidade limitante.

Logo abaixo do nível dos princípios encontra-se o plano dos entes ideais, articulado, por sua vez, em três diferentes subseções: os números e as figuras ideais, as ideias supremas ou metaideias, as ideias gerais e particulares. A distinção entre ideias particulares, ideias gerais e ideias supremas (ou metaideias) já tinha sido claramente formulada no Sofista. A verdadeira novidade das doutrinas não escritas consiste na inserção dos números ideais (ou das ideias-números). Trata-se 
de um dos pontos mais difíceis dessa teoria, porque os testemunhos dizem que Platão teria identificado as ideias com os números. Mas parece improvável que esta informação possa ser levada à letra.

Para entender o que Platão quis dizer, devemos levar em consideração que os gregos concebiam os números não como entidades definidas, mas principalmente como proporções e relações entre grandezas (logos); por isso, é provável que Platão tenha utilizado os números e as grandezas ideais (que são justamente as ideias de tais entes, e não estão sujeitos a operações) para representar os logoi, ou seja, as relações existentes entre ideias gerais e as menos gerais. Mas não vamos insistir nesse ponto, porque é considerado bastante delicado até pelos estudiosos da escola de Tübingen.

Entre os entes ideais e as coisas sensíveis existe ainda uma quarta classe de objetos, que são os entes matemáticos propriamente. Eles consistem, em ordem decrescente de unidade e simplicidade, em objetos da matemática, da geometria plana, da geometria sólida, da astronomia pura e da musicologia. A necessidade de incluir estes entes, denominados "intermédios", deriva do fato que nem as ideias matemático-geométricas nem as coisas numeradas ou as figuras geométricas concretas são objeto das operações matemáticas: o teorema de Pitágoras, por exemplo, não vale nem para um triângulo ideal nem para um triângulo concreto. Eis agora explicada a necessidade de usar os entes matemáticos intermédios entre as coisas sensíveis $\mathrm{e}$ as ideias. 
Uma outra propriedade dos números matemáticos e das figuras geométricas é serem compostos, respectivamente, de mônadas ou unidades singulares e de linhas indivisíveis, que, por sua vez, são constituídas pela ação do uno sobre o grande e o pequeno. Essa estrutura de composição e decomposição diz respeito também aos quatro elementos corpóreos, que correspondem, como sabemos pelo Timeu, a poliedros regulares: tais poliedros surgem da sucessiva agregação de pontos em linhas, de linhas em superfícies, e depois de superfícies em sólidos. De tal maneira, Platão pode demonstrar que toda a realidade, mesmo em proporções diferentes segundo os níveis de perfeição, é oriunda da mistura da unidade com a multiplicidade.

Esse tema é destacado também de outro que se pode extrair das doutrinas não escritas. Parece que Platão tinha dividido toda a realidade em duas grandes categorias, de acordo com uma perspectiva que antecipa de modo embrionário a de Aristóteles: 1) entes que existem por si só; 2) entes que existem em relação a outros (ou relativos); esse segundo grupo é, por sua vez, diferenciado em opostos (do tipo igual-desigual) e correlativos (do tipo grande-pequeno). A principal diferença entre opostos e correlativos é que somente os segundos toleram a variação e a existência de estados intermediários. Essa classificação "categorial” possui o objetivo de mostrar que em alguns entes (os por si só) prevalece a determinação da unidade, e que nos outros entes (os relativos), prevalece a da dualidade indeterminada. Mas ambos os princípios são necessários para cada coisa. 
Se a atribuição e a reconstrução dessa teoria são exatas, podemos chegar a conclusões interessantes. Dentro da imagem tradicional da filosofia platônica, a distinção entre por si e relativos, só pode corresponder à distinção entre ideias (que são o ser verdadeiro, o existente por si só) e coisas. Mostrar que a ação de unidade e multiplicidade interessa ambos os níveis corresponde completamente a uma orientação do pensamento platônico presente também nos últimos escritos, ou seja, a de recompor a rígida contraposição dos dois mundos à luz de uma teoria dos princípios mais geral, capaz de mostrar tanto em um quanto no outro a presença da mesma estrutura: pensemos, por exemplo, na admissão do não ser dentro do próprio mundo ideal (no Sofista), ou na mistura do limite e do ilimitado teorizada no Filebo; e, inversamente, consideremos o Timeu, onde o princípio ideal e limitante é inscrito no coração da própria matéria.

A absoluta universalidade da ação dos dois princípios é também confirmada pelo fato que eles possuem uma valência não só ontológica e metafísica, mas também funcional; esses princípios se manifestam de diversos modos nos vários níveis da realidade. $\mathrm{O}$ não ser do Sofista, o ilimitado do Filebo e a chora do Timeu, por exemplo, mesmo sendo três modos nos quais se manifesta e age o idêntico princípio do ilimitado, não se pode dizer, porém, que sejam a mesma coisa. A natureza funcional dos princípios resulta com clareza do duplo procedimento mediante o qual Platão os busca: um procedimento simplificador, virado para a identificação dos constituintes primários da realidade 
(para os quais os princípios desempenham a função de elementos), e um procedimento generalizante, que tem o propósito de apreender o múltiplo em unidades sempre mais gerais (para o qual os princípios desempenham a função de gêneros).

A teoria que acabamos de expor parece coincidir muito bem, como tentamos demonstrar, com as orientações teóricas já visíveis nos últimos diálogos (do Parmênides ao Timeu). Mas existe uma aparente exceção. Entendo aludir à natureza e à colocação do segundo princípio, que parece desenvolver a função de causa metafísica do mal incluído sob o ser. Mas, nesse caso, encontrar-se-ia a estranha anomalia de um princípio que é, de um lado, causa universal por concomitância de todo o ser e, portanto, deveria ser superior a ele também do ponto de vista do valor; e, do outro, possui características negativas, porque é causa somente de males e de imperfeições.

Mas provavelmente não se trata de um problema insolúvel. É razoável pensar que, para Platão, o verdadeiro princípio fosse somente um, ou seja, o unobem, que também é a única realidade "além do ser", realmente transcendente. O segundo princípio seria uma espécie de recipiente, no qual se acomodam todas as várias formas de multiplicidade que caracterizam o ser, que é, como sabemos, sempre formado por uma multiplicidade qualquer. $\mathrm{O}$ sentido último da metafísica platônica consistiria em reconhecer que na multiplicidade está também sempre presente a unidade; portanto, a multiplicidade pura "não existe", e é necessário postular uma unidade pura "além do ser", 
para motivar o fato que o ser resulta, sempre e contudo, determinado também pela unidade. Dessa forma, o princípio da multiplicidade se assemelhará não mais ao não ser (de acordo com a acusação que Aristóteles fará a Platão, Metafísica XIV, 1089a), mas, sobretudo ao ser, assim como acredita o próprio Aristóteles; não uma categoria homogênea, mas uma pluralidade de modos de ser que, em Platão, correspondem aos diversos modos nos quais existe a multiplicidade: na matéria, nas coisas, nos entes matemáticos, nas ideias, nas ideias-números. 
(Página deixada propositadamente em branco) 


\section{BIBLIOGRAFIA}

\section{AS OBRAS PLATÔNICAS}

A edição crítica do texto original grego mais utilizada pelos estudiosos contemporâneos é aquela organizada por JOHN BURNET (5 vols., Oxford University Press, Oxford 1900-07, reimprimida muitas vezes). Na mesma coleção dos "Oxford Classical Texts", está previsto um republicação do trabalho de Burnet, do qual, até o momento, foram impressos dois volumes. O primeiro contém o Eutífron, a Apologia de Sócrates, o Criton, o Fédon, o Crátilo, o Teeteto, o Sofista e o Político (sob a organização de E. A. DUKE, W. F. HICKEN, W. S. M. NICOLL, D. B. ROBINSON E J. C. G. STACHAN, Oxford University Press, Oxford 1995); o segundo traz somente $A$ República (ao cuidado de S. R. SLINGS, Oxford University Press, Oxford 2003). Outra importante edição crítica, munida da tradução francesa, introduções monográficas e breve 
comentário, é aquela integrante da série de clássicos gregos ("Collection Budé") da editora parisiense Les Belles Lettres, dividida em 14 tomos (num total de 25 volumes) lançados entre 1924 e 1960 (mas também as Belles Lettres iniciaram recentemente um programa de republicações atualizadas, das quais já saíram, por ora, o Fédon e o Fedro). Encontramos também ediçôes críticas do texto grego nas coleções gregas da editora alemã Teubner e da inglesa Loeb (com a tradução presente).

As traduçôes italianas mais recentes são as seguintes:

4. Opere complete, organizado por G. GIANNANTONI e colaboradores, Laterza, Bari 1971 e reedições sucessivas (9 vols.).

5. Dialoghi, organizado por G. CAMBIANO e F. ADORNO, UTET, Torino 1970-88.

6. Tutti gli scritti, organizado por G. REALE e colaboradores, Rusconi, Milano 1991 (agora Bompiani).

7. Tutte le Opere, com texto grego presente, organizado por V. MALTESE, Newton Compton, Roma 1997.

Entre as numerosas traduções italianas comentadas de cada diálogo, assinalamos: Apologia di Socrate, Critone, organizado por A. M. IOPPOLO, Laterza, Roma-Bari 1996; Teage, Carmide, Lachete, Liside, organizado por B. CENTRONE, Rizzoli, Milano 1997; Fedone, organizado por M. VALGIMIGLI e B. CENTRONE, Laterza, Roma-Bari 2000; La Repubblica, organizado por M. VEGETTI, Rizzoli, Mila- 
no 2007; Teeteto, organizado por A. M. IOPPOLO, Laterza, Roma-Bari 1999; Parmenide, organizado por F. FRONTEROTTA, Laterza, Roma-Bari 1998; Sofista, organizado por B. CENTRONE, Rizzoli, Milano 2008; Político, organizado por P. ACCATTINO, Laterza, Roma-Bari 1997; Timeo, organizado por F. FRONTEROTTA, Rizzoli, Milano 2003; Le Leggi, organizado por F. FERRARI e S. POLI, Rizzoli, Milano 2005; Lettere, organizado por M. ISNARDI PARENTE, Fondazione Lorenzo Valla-Mondadori, Milano 1995; Fedro, organizado por F. TRABATTONI, Bruno Mondadori, Milano 1995; Ione, organizado por F. TRABATTONI, La Nuova Italia, Firenze 2004; F. TRABATTONI (a cura di), Platone. Liside (2 vols.), LED, Milano 2003-04.

Os testemunhos indiretos sobre o ensino oral de Platão se encontram recolhidos em H. KRÄMER, Platone e i fondamenti della metafísica, Vita e Pensiero, Milano 1992, pp. 371-417 e em M. ISNARDI PARENTE, Testimonia Platônica I e II, in "Atti dell'Accademia Nazionale dei Lincei”, 1997 e 1998.

\section{LÉXICOS}

O primeiro léxico platônico completo é aquele organizado no século XIX por FR. AST (Lexicon Platonicum, 3 vols., Berlim, 1835-1838). Também muito completos são os léxicos organizados por $\mathrm{L}$. BRANWOOD (A Word Index to Plato, W. S. Maney and Son, Londres, 1976) e R. RADICE (com a cola- 
boração com I. RAMELLI e E. VIMERCATI: Lexicon. I. Plato, Biblia, Milão, 2003). Estes dois últimos léxicos foram diagramados com o auxílio do computador, o segundo particularmente apresenta a dupla vantagem de que existe tanto em formato impresso como em versão software. Outro bom léxico, ainda que incompleto, faz parte da edição francesa das obras de Platão "Collection Budé" (ver supra), t. XIV (2 vols.), por É. DES PLACES. Todos esses textos trazem os respectivos originais em grego.

\section{REPERTÓRIOS BIBLIOGRÁFICOS}

Um indispensável instrumento a respeito de toda a cultura antiga é o "Année Philologique", publicação anual que traz uma seção dedicada a Platão (disponível em versão eletrônica, não gratuita). Para a bibliografia especificamente platônica, o meio mais cômodo é o web site da Internacional Plato Society (www.platosociety.org) que traz on-line a bibliografia de 2001 a 2008 e assinala os instrumentos impressos a serem utilizados para aos anos anteriores. ${ }^{1}$

1. N. do Editor: a Sociedade Brasileira de Platonistas (SBP), membro institucional da International Plato Society, mantém um web site (www.platao.org) com informaçóes sobre eventos, publicações e atividades dos platonistas no Brasil. 


\section{BIBLIOGRAFIA GERAL DE REFERÊNCIA}

ADORNO F., Introduzione a Platone, Laterza, Roma-Bari 1978.

BIRAL A., Platone e la conoscenza di sé, Laterza, Roma-Bari 1997.

BRISSON L., FRONTERROTTA, F. (a cura di), Lire Platon, PUF, Paris 2006.

CAMBIANO G., Platone e le tecniche, Einaudi, Torino 1971.

DIÈS A., Autour de Platon, Paris, 1926.

DIXSAUT M., La natura filosofica. Saggio sui dialoghi di Platone, Loffredo, Napoli 2003 (ed. or. 2001).

FRIEDLÄNDER P., Platon: Eidos, Paideia, Dialogos, Berlin De Gruyter 1928.

GADAMER H., Dialogue and Dialectic: Eight Hermeneutical Studies on Plato, Yale University Press, 1980. 
HAVELOCK E., Home, Plato, and two Cultures, Oxford Blackwell 1963.

JAEGER W., Paideia, die formung dês Griechischen Menschen, De Gruyter 1936.

KRAUT R., The Cambridge Companion to Plato, Cambridge University Press, Cambridge 1992.

REALE G., Per uma nuova interpretazione di Platone, Vita e Pensiero, Milano 1997.

ROBIN L., Platon, F. Alcan 1935.

RYLE G., Plato’s Progress, Cambridge 1966.

STEFANINI L., Platone, CEDAM, Padova 1949.

TAYLOR A., Plato: The Man and His Work, Dover Publication.

TRABATTONI F., Platone, Carocci, Roma 1998.

VEGETTI M., Quindici Lezioni su Platone, Einaudi, Torino 2003. 


\section{MONOGRAFIAS PARA CADA VOLUME}

BARBANTI M., ROMANO F., Il Parmenide di Platone e la sua tradizione, CUECM, Catânia 2002.

BRISSON L., Le même et l'autre dans La structure ontologique du Timée de Platon, Academia, Sankt Augustin 1998.

CAPPUCCINO C., Filosofi e rapsodi. Testo, traduzione e commento dello Ione platonico, CLUEB, Bologna 2005.

CAPRA A., Il Protagora di Platone tra eristica e commedia, LED, Milão 2001.

CASERTANO G., Il Teeteto di Platone: struttura e problematiche, Loffredo, Napoli 2001.

CASERTANO G., Il Protagora di Platone: struttura e problematiche, Loffredo, Napoli 2004.

CASERTANO G., Il Cratilo di Platone: struttura e problematiche, Loffredo, Napoli 2005.

CHAPPELL T., Reading Plato's Theaetetus, Hackett, Indianapolis-Cambridge 2005. 
DELCOMMINETTE S., Le Philèbe de Platon, Brill, Leida 2006.

FERRARI G. R. F., Cambridge Companion to Plato's Republic, Cambridge University Press 2007.

FUSSI A., Retorica e potere. Una lettura del Gorgia di Platone, ETS, Pisa 2006.

GATTI M. L., Etimologia e filosofia. Strategie comunicative del filosofo nel Cratilo di Platone, Vita e Pensiero, Milano 2006.

ISNARDI PARENTE M., Filosofia e politica nelle Lettere di Platone, Guida, Napoli 1970.

LESHER G., NAILS D., SHEFFIELD F. C. C., Plato's Symposium. Issues in Interpretation and Reception, Center for Hellenic, Washington 2006.

LIMINTA M. T., Il problema della bellezza in Platone. Analisi e interpretazione dellIppia Maggiore, Vita e Pensiero, Milano 1998.

MIGLIORI M., Dialettica e verità. Commento filosófico al Parmenide di Platone, Vita e Pensiero, Milano 1990.

MOUZE L., Le legislateur et le poète, Une interpretation dês Lois des Platon, Presses Universitaires du Septentrion, Villeneuve-d'Ascq 2005.

PALUMBO L., Il non essere e l'apparenza. Sul Sofista di Platone, Napoli 1994.

PANNO G., Dionisiaco e alterità nelle Leggi di Platone, Vita e Pensiero, Milano 2007.

ROSSETTI L., Understanding the Phaedrus, Academia, Sankt Augustin 1992. 
TRABATTONI F., Platone. Liside, LED, Milano 2003-2004.

TULLI M., Dialettica e scrittura nella VII Lettera di Platone, Giardini, Pisa 1989.

VEGETTI M., Platone. La Repubblica. Traduzione e commento, Bibliopolis, Napoli 1998-2007.

VEGETTI M., Guida alla Repubblica di Platone, Laterza, Roma-Bari 1999.

\section{DIÁLOGO, MITO E FORMAS DA COMUNICAÇÃO}

BLONDELL R., The Play of Characteurs in Plato's Dialogues, Cambridge University Press, Cambridge 2002.

CASERTANO G., La struttura del dialogo platonico, Loffredo, Napoli 2000.

CERRI G., Platone sociologo della comunicazione, Il Saggiatore, Milano 1991.

ERLER M., Der Sinn der Aporien in den Dialogen Platons, Berlin-New York 1987.

FERRARI F., I miti di Platone, Rizzoli, Milano 2006.

GAISER K., Platone como scrittore filosofico, Bibliopolis, Napoli 1991.

GAISER K., La dottrina non scritta di Platone, Vita e Pensiero, Milano 1991.

GIANNANTONI G., Dialogo socratico e nascita della dialettica nella filosofia di Platone, Bibliopolis, Napoli 2005. 
LONGO A., La tecnica della domanda e le interrogazioni fittizie in Platone, Scuola Normale Superiore, Pisa 2000.

PRESS G., Who Speaks for Plato? Studies in Platonic Anonymity, Rowman \& Littlefield, Lanham 2000.

\section{AS IDEIAS, OS PRINCÍPIOS, A DIALÉTICA}

CASERTANO G., L'eterna malattia del discorso (quattro studi su Platone), Liguori, Napoli 1991.

CASERTANO G., Il nome della cosa. Linguaggio e realtà negli ultimi dialoghi di Platone, Loffredo, Napoli 1996.

CASERTANO G., Paradigmi della verità in Platone, Editori Riuniti, Roma 2007.

DI GIOVANNI P., Platone e La dialettica, Laterza, RomaBari 1995.

DIXSAUT M., Métamorphoses de la dialéctique dans les dialogues de Platon, Vrin, Paris 2001.

FINE G., Plato on Knowledge and Forms, Clarendon Press, Oxford 2003.

FRONTEROTTA F., La teoria platonica delle idee e la partecipazione delle cose empiriche. Dai dialoghi giovanili al Parmenide, Scuola Normale Superiore, Pisa 2001.

GONZALEZ F., Dialectic and Dialogue. Plato's Practice of Philosophical Inquiry, Northwestern University Press, Evanston 1998.

REALE G., SCOLNICOV S., New Images on Plato. Dialogues on the Idea of the Good, Academia, Sankt Augustin 2002 
ROSS D., Plato's Theory of Ideas, Greenwood Press 1976.

TRABATTONI F., Scrivere nell'anima. Verità, dialettica e persuasione in Platone, La Nuova Italia, Florença 1994.

\section{A ALMA, O EROS, A POESIA}

CASSIRER E., Eidos e Eidolon. Il problema del bello e dell'arte nei dialoghi di Platone, Raffaello Cortina, Milanoo 2009 (ed. orig. 1922-1923).

GHIDELLI C., Dall'ordine alla vita. Mutamenti del bello nel platonismo antico, CLUEB, Bologna 1999.

GIUliano F. M., Platone e la poesia, Academia, Sankt Augustin 2005.

MIGLIORI M., NAPOLITANO VALDITARA L., FERMANI A., Interiorità e anima. La psyche in Platone, Vita e Pensiero, Milano 2007.

NIGTHINGALE A. W., Genres in Dialogue. Plato and the Construct of Philosophy, Cambridge University Press, Cambridge 1995 .

REALE G., Eros demone mediatore e Il gioco delle maschere nel Simposio di Platone, Rizzoli, Milano 1997.

ROBINSON T., Plato's Psychology, University of Toronto Press, Toronto 1970.

SANTAS G., Plato Freud: Two Theories of Love, Basil Blackwell, Oxford 1988.

VELARDI R., Enthousiasmòs. Possessione rituale e teoria della comunicazione peotica in Platone, Edizione dell'Ateneo, Roma 1989. 


\section{ÉTICA E POLÍTICA}

ISNARDI PARENTE M., Il pensiero politico di Platone, Laterza, Roma-Bari 1996.

MIGLIORI M., NAPOLITANO VALDITARA L., Plato Ethicus. La filosofia è vita, Morcelliana, Brescia 2008.

QUARTA C., L'utopia Platonica, Franco Angeli, Milano 1985.

SCHOFIELD M., Plato. Political Philosophy, Oxford University Press, Oxford 2006.

VEGETTI M., Un paradigma in cielo, Platone politico da Aristotele al Novecento, Carocci, Roma 2009.

WOLF U., La filosofia come ricerca della felicita. I dialoghi giovanili di Platone, Raffaello Cortina, Milano 2001 (Ed. orig. 1996).

\section{A RELAÇÃO ENTRE ORALIDADE E ESCRITA E AS DOUTRINAS NÃO ESCRITAS}

GAISER K., La dottrina non scritta di Platone, Vita e Pensiero, Milano 1994 (ed. orig. 1968).

KRÄMER H., Platone e i fondamenti della metafísica, Vita e Pensiero, Milano 1982.

SALMERI G., Il discorso e la visone. I limite della ragione in Platone, Studium, Roma 1999.

SZLEZÁK TH., Come leggere Platone, Rusconi, Milano 1991. 
SZLEZÁK TH., Platone e la scrittura della filosofia, Vita e Pensiero, Milano 1988 (ed. orig. 1985).

TRABATTONI F., La verità noscosta. Oralità e scrittura in Platone e nella Grecia classica, Carocci, Roma 2005. 
(Página deixada propositadamente em branco) 


\section{ÍNDICE DAS CITAÇÓES PLATONNICAS}

\begin{tabular}{|c|c|}
\hline Alcibiades I & Eutidemo \\
\hline $128 \mathrm{a}$ & $273 \mathrm{~d}, 60$ \\
\hline $128 \mathrm{~d}, 133$ & $278 \mathrm{e}, 30$ \\
\hline $128 \mathrm{e}, 133$ & $279 e-280 a, 67$ \\
\hline $128 \mathrm{e}-129 \mathrm{a}, 133$ & $282 \mathrm{a}, 30$ \\
\hline 129b-e, 133 & $305 b-306 d, 6 c$ \\
\hline \multicolumn{2}{|l|}{$130 c, 133$} \\
\hline Apologia de Sócrates & $4 \mathrm{~b}, 41$ \\
\hline $20 e, 36$ & $4 b-c, 40$ \\
\hline $21 \mathrm{~d}, 36$ & $4 c, 40$ \\
\hline $29 \mathrm{~d}, 30 \mathrm{a}, 132$ & $4 e, 43$ \\
\hline $31 c-32 a, 166$ & $5 d-6 b, 43$ \\
\hline \multirow[t]{2}{*}{$40 c-d, 141$} & $9 \mathrm{~d}, 44$ \\
\hline & $9 e-10 e, 44$ \\
\hline Crátilo & \\
\hline $438 b, 74$ & \\
\hline $440 \mathrm{~b}, 75$ & \\
\hline $440 c, 74$ & \\
\hline
\end{tabular}


Fédon

62b, 136

65a-67b, 135

66b-67a, 95

70c-72e, 142

$72 \mathrm{e}-77 \mathrm{~b}, 92 \mathrm{ss}$.

$74 a-b, 93$

$74 d-e, 93$

75c-d,93, 105

78b-80b, 143

79a, 107

$79 \mathrm{~d}, 107$

$80 a-b, 135$

80b, 107

$82 \mathrm{~d}-83 \mathrm{~b}, 135$

$85 \mathrm{c}-\mathrm{d}, 146$

85e-86d, 137

86d-88b, 143

$94 \mathrm{~b}, 137$

95e-100a, 143

96d-e, 79

96e-97a, 79

97c, 81

97d-e, 81, 82

98c, 81

98c-99d, 82

$99 \mathrm{c}-\mathrm{d}, 98$

99e, 99

99e-100a, 99

100a-106d, 144

100c, 103

100d, 80

101a, 80
$105 \mathrm{c}-\mathrm{d}, 146$

107b, 146

Fédro

237b-241d, 157

238b-c, 157

$244 \mathrm{a}-245 \mathrm{a}, 158$

245c-246a, 144

246a-b, 140

249b-c, 96

249 e, 160

250a, 158

250c-e, 159

250e-251a, 122

256c-e, 160

258d, 162

259d-260d, 162

262a, 54

265c-266c, 163

275d-e, 163

277e-278b, 162

278a, 163

278d, 162

278e-279a, 60

Filebo

11d, 243

15a, 244

$15 \mathrm{~d}, 245$

16c-d, 246

19a-20a, 241

19b, 247

19c, 247 


$\begin{array}{ll}\text { 20c, 248 } & \text { As Leis } \\ \text { 20d, 248 } & \text { 630b, 287 } \\ \text { 22c, 248 } & \text { 632e-633a, 287 } \\ \text { 23c-27c, 249 } & \text { 633e-634a, 287 } \\ \text { 23d, 249 } & \text { 641c, 288 } \\ \text { 26d, 250 } & 643 \mathrm{e}, 288 \\ \text { 27e, 250 } & \text { 644b, 288 } \\ \text { 31a, 251 } & \text { 644e-645c, 288 } \\ \text { 37b-40e, 251 } & \text { 653c, 289 } \\ \text { 43d-44a, 252 } & \text { 677a-681c, 290 } \\ \text { 50e-51d, 252 } & \text { 689a, 291 } \\ \text { 55c-58e, 253 } & \text { 693d, 291 } \\ \text { 61a, 249 } & 702 \mathrm{~d}, 292 \\ \text { 62c-d, 253 } & 709 \mathrm{a}-\mathrm{c}, 292 \\ \text { 66a-d, 253 } & 712 \mathrm{a}, 292 \\ & 713 \mathrm{~d}, 277 \\ \text { Górgias } & 714 \mathrm{e}, 293 \\ \text { 460a, 54 } & 716 \mathrm{c}, 296 \\ \text { 477a-b, 133 } & 720 \mathrm{~b}-\mathrm{e}, 294 \\ \text { 477d-e, 134 } & 721 \mathrm{a}-\mathrm{b}, 296 \\ \text { 491e-492c, 31 } & 722 \mathrm{c}-723 \mathrm{~b}, 294 \\ \text { 500c, 30 } & 726 \mathrm{a}-734 \mathrm{e}, 295 \\ \text { 505b, 32 } & 731 \mathrm{c}, 295 \\ \text { 515d-517a, 169 } & 731 \mathrm{e}-734 \mathrm{c}, 295 \\ \text { 521d, 166 } & 736 \mathrm{c}, 295 \\ & 739 \mathrm{a}-\mathrm{b}, 296 \\ \text { Ion } & 739 \mathrm{c}, 296 \\ \text { 533d-535a, 38 } & 739 \mathrm{e}-745 \mathrm{a}, 297 \\ \text { Hipias Maior } & 743 \mathrm{c}, 297 \\ \text { 287d, 87 } & \text { 746a-d, 187 } \\ \text { 288b-289d, 86 } & 756 \mathrm{c}-\mathrm{d}, 299 \\ & 756 \mathrm{e}, 299 \\ \end{array}$


757d-e, 299

$777 \mathrm{~d}-778 \mathrm{a}, 300$

783d-785b, 300

788b, 302

$804 \mathrm{~d}, 301$

808a, 302

$817 \mathrm{a}, 301$

857c-864a, 302

862a-b, 303

862d, 303

863e-864a, 304

885b, 304

$887 \mathrm{a}-\mathrm{c}, 305$

$887 \mathrm{~d}, 305$

887e, 305

889e-890a, 306

891d, 306

892b, 307

892c, 306

894b, 307

896a, 307

899b, 308

900e, 308

903c, 308

904c, 309

961a-c, 310

Mênon

80e, 92

82b-85b, 92

91b, 59

97a-98b, 39
Parmênides

128d-e, 214

129e, 215

129b-130a, 215

129d, 244

130d, 108

130e, 108

130e-131a, 216

131c-e, 216

132a-b, 217

132c, 217

134b, 218

135c, 219

$135 \mathrm{c}-\mathrm{d}, 222$

136a-c, 223

136c, 241

Politico

258c, 276

262c, 276

267b-c, 276

267e, 277

268c-d, 276

268d-274a, 277

274e-275a, 277

279a-283a, 279

287b-289a, 280

289a-e, 300

290d-e, 280

291d, 280

293a, 281

293d-294c, 281

297b-c, 282 


$\begin{array}{ll}\text { 300a, 282 } & \text { 379c-380c, 47 } \\ \text { 300b, 284 } & 381 \mathrm{~b}, 47 \\ \text { 300c, 284 } & 399 \mathrm{c}-403 \mathrm{c}, 174 \\ \text { 302b-303a, 283 } & 410 \mathrm{c}, 174 \\ \text { 304c-d, 285 } & 410 \mathrm{e}-412 \mathrm{a}, 174 \\ & 412 \mathrm{~d}, 175 \\ \text { Protágoras } & 414 \mathrm{~b}-415 \mathrm{~d}, 176 \\ \text { 312d, 59 } & 415 \mathrm{~d}-417 \mathrm{~b}, 178 \\ \text { 318e-319a, 55 } & 419 \mathrm{a}-420 \mathrm{a}, 179 \\ \text { 319a-320c, 55 } & 420 \mathrm{~b}-421 \mathrm{c}, 179 \\ \text { 320c-328d, 57 } & 424 \mathrm{a}, 184 \\ \text { 329c } & 428 \mathrm{c}-429 \mathrm{a}, 181 \\ \text { 351b, 57 } & 429 \mathrm{c}, 181 \\ \text { 353c-357e, 58 } & 431 \mathrm{~d}, 181 \\ \text { 358a, 58 } & 432 \mathrm{a}, 181 \\ & 433 \mathrm{~b}, 181 \\ \text { A República } & 438 \mathrm{~d}-440 \mathrm{a}, 139 \\ \text { 330d-331b, 42 } & 441 \mathrm{c}-443 \mathrm{~b}, 183 \\ \text { 331c-e, 86 } & 451 \mathrm{c}-457 \mathrm{~b}, 185 \\ \text { 331e-332a, 168 } & 457 \mathrm{~b}-461 \mathrm{e}, 186 \\ \text { 338c, 168 } & 457 \mathrm{~d}, 187 \\ \text { 352d, 30 } & 465 \mathrm{~d}-466 \mathrm{~d}, 186 \\ \text { 362c, 45 } & 472 \mathrm{~b}-\mathrm{e} \\ \text { 364c-e, 45 } & 473 \mathrm{a}-\mathrm{b}, 187 \\ \text { 365a-366a, 46 } & 473 \mathrm{c}-\mathrm{d}, 189 \\ \text { 368c-369a, 171 } & 475 \mathrm{e}, 189 \\ \text { 369b-371b, 171 } & 477 \mathrm{a}-478 \mathrm{~d}, 123 \\ \text { 372d, 172 } & 478 \mathrm{e}-479 \mathrm{a}, 72 \\ \text { 376c, 173 } & 480 \mathrm{a}, 123 \\ \text { 377e, 46 } & 484 \mathrm{c}-487 \mathrm{~b} \\ \text { 378b, 47 } & 484 \mathrm{c}-\mathrm{d}, 191 \\ \text { 378b-c, 47 } & 487 \mathrm{c}-\mathrm{d}, 191 \\ \text { 379a, 47 } & 501 \mathrm{e}, 25 \\ & \\ & \\ & \end{array}$


504a-509b, 126

505a, 126

506b-e, 126, 129

509b, 126

509e-511e, 112

510c-e, 114

511b, 114

511d-e, 113

514a, 116

515a, 117

517b, 129

523a, 118

524c, 119

525c, 119, 129

525d, 120

526d-e, 128

527b, 119

528a, 120

$529 \mathrm{c}-\mathrm{d}, 128$

530d, 128

531e, 120

532a-b, 114, 120

532d-b, 117

533a, 129

534b-c, 128

544e, 192

546a, 192

546d, 192

554a-b, 193

557c, 194, 199

558c-562a, 194

563a-b, 194

566b, 195 568d-569c, 195

572b, 196

572c-d, 199

577c-580c, 196

581e-583a, 197

583b-586c, 197

592b, 192

597a-602b, 198

608c-d, 199

608d-610a, 145

614b-621d, 200

617d-e, 201

$O$ Banquete

189c-194c, 149

199c-201c, 150

202a, 123

204b, 151

204d, 151

205a, 152

205a-b, 152

206b-207a, 152

209d-e, 153

210a, 155

210e-211b, 154

212a, 155

Sofista

217c, 204

218d-221c, 225

221c-226a, 226

226b-231b, 226 


\begin{tabular}{|c|c|}
\hline $231 \mathrm{a}, 227$ & $185 e, 76$ \\
\hline $233 c-d, 227$ & 186b, 77 \\
\hline $238 d-241 b, 228$ & $186 \mathrm{c}, 77$ \\
\hline 239a, 229 & $186 \mathrm{~d}, 77$ \\
\hline $241 \mathrm{~d}, 230$ & $187 b, 205$ \\
\hline $241 \mathrm{e}, 230$ & $188 c-d, 206$ \\
\hline $243 \mathrm{~d}, 230$ & 189a-b, 206 \\
\hline $243 e-244 b, 231$ & 189d, 207 \\
\hline $244 b-245 e, 231$ & $189 \mathrm{e}-190 \mathrm{a}, 124$ \\
\hline $246 a-c, 232$ & 190b-c, 207 \\
\hline $247 b, 233$ & $194 c-195 b, 207$ \\
\hline $247 e, 233$ & 199a-b, 208 \\
\hline $248 d, 233$ & $199 \mathrm{e}, 209$ \\
\hline $249 a, 234$ & 206d, 211 \\
\hline $249 b, 234$ & 206d-e, 212 \\
\hline $250 \mathrm{~d}, 235$ & 206e-207a, 211 \\
\hline $251 c, 236$ & $208 b, 212$ \\
\hline $252 b-e, 236$ & $208 c, 211$ \\
\hline $253 \mathrm{~d}, 237$ & $208 c-209 e, 212$ \\
\hline \multicolumn{2}{|l|}{$254 \mathrm{c}, 237,241$} \\
\hline $256 e-257 a, 238$ & Timeu \\
\hline $264 a, 124$ & $19 b-c, 254$ \\
\hline \multirow[t]{2}{*}{$268 c-d, 239,276$} & $27 d-28 a, 255$ \\
\hline & $29 b-d, 257$ \\
\hline Teeteto & $29 c, 257$ \\
\hline $151 e, 63$ & $29 d-e, 259$ \\
\hline $153 e, 64$ & $30 c, 259$ \\
\hline $161 b-164 c, 65$ & $31 a-b, 259$ \\
\hline $166 a-168 c, 65$ & $34 a, 260$ \\
\hline $167 d, 66$ & $35 a, 260$ \\
\hline $172 a-b, 67$ & $37 d-e, 261$ \\
\hline $173 b-177 c, 116$ & $37 e-38 a, 261$ \\
\hline $184 a, 75$ & $38 \mathrm{c}, 261$ \\
\hline
\end{tabular}




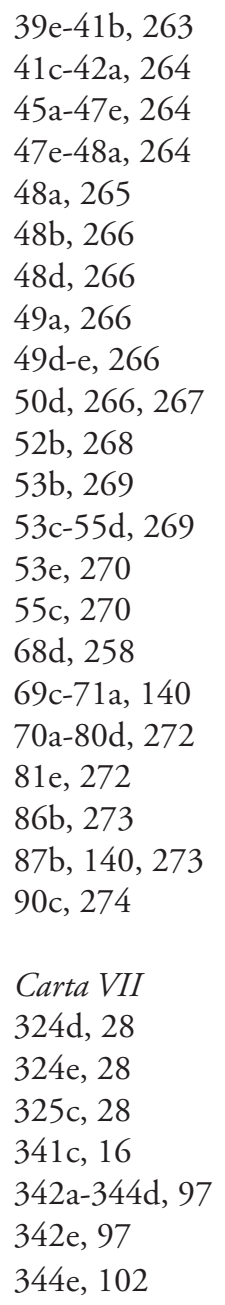


(Página deixada propositadamente em branco) 
$\int \begin{aligned} & \mathrm{m} \text { manual introdutório e propedêuti-co, } \\ & \text { portanto amplamente acessível a um } \\ & \text { público leigo, ao pensamento de um dos }\end{aligned}$ maiores pensadores de todos os tempos, escrito com a maestria de um autor que se encontra atualmente entre os mais reconhecidos intérpretes de Platão em nível internacional. 